In cooperation with the Pennsylvania Department of Agriculture

Pesticides in Ground Water in Selected Agricultural Land-Use Areas and Hydrogeologic Settings in Pennsylvania, 2003-07

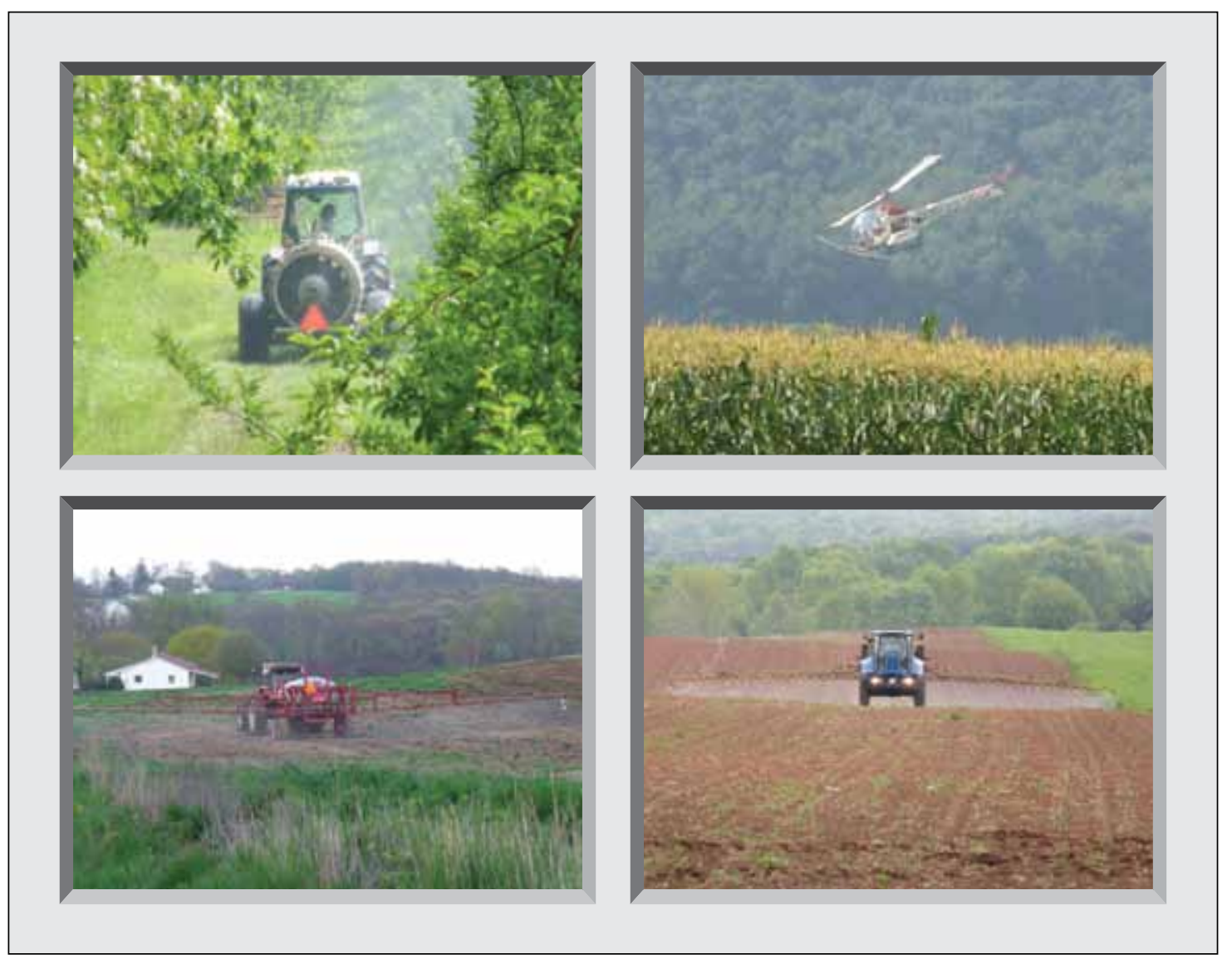

Scientific Investigations Report 2009-5139 

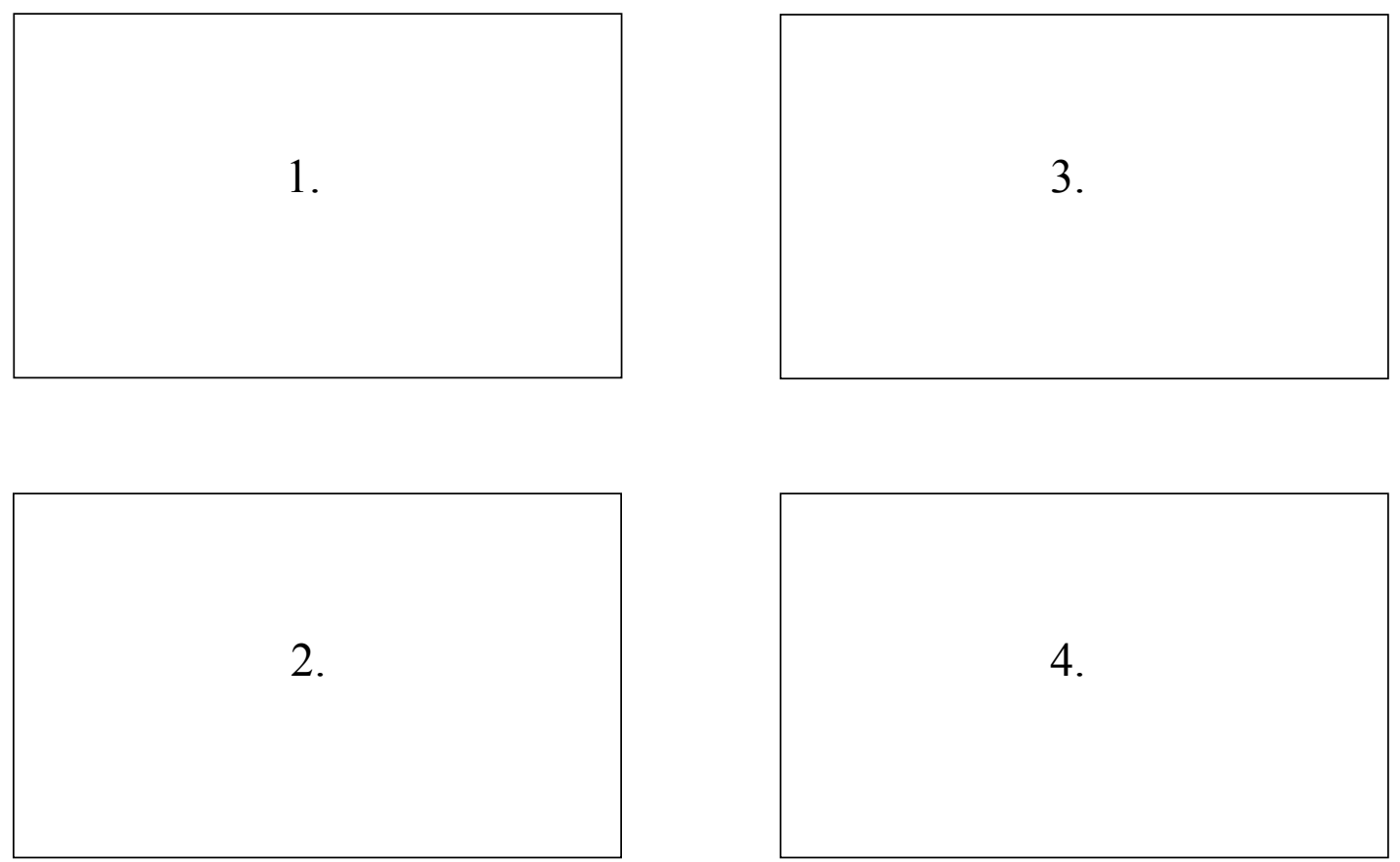

Cover:

1. Application of pesticides in a fruit orchard by use of an air-blast sprayer, May 2008. Photograph taken by Joanne Irvin, U.S. Geological Survey.

2. Application of pesticides to a field near a home with a domestic well by use of a tractor with a spray tank and boom-type applicator, April 2008. Photograph taken by Connie Loper, U.S. Geological Survey.

3. Application of pesticides on corn by use of helicopter with boom-type applicator, July 2007. Photograph taken by John Clune, U.S. Geological Survey.

4. Pesticide application to row crops by use of a commercial or custom boom-type applicator, May 2007. Photograph by Connie Loper, U.S. Geological Survey. 


\section{Pesticides in Ground Water in Selected Agricultural Land-Use Areas and Hydrogeologic Settings in Pennsylvania, 2003-07}

By Connie A. Loper, Kevin J. Breen, Tammy M. Zimmerman, and John W. Clune

In cooperation with the Pennsylvania Department of Agriculture

Scientific Investigations Report 2009-5139 


\section{U.S. Department of the Interior \\ KEN SALAZAR, Secretary \\ U.S. Geological Survey \\ Suzette M. Kimball, Acting Director}

U.S. Geological Survey, Reston, Virginia: 2009

For more information on the USGS - the Federal source for science about the Earth, its natural and living resources, natural hazards, and the environment, visit http://www.usgs.gov or call 1-888-ASK-USGS

For an overview of USGS information products, including maps, imagery, and publications, visit http://www.usgs.gov/pubprod

To order this and other USGS information products, visit http://store.usgs.gov

Any use of trade, product, or firm names is for descriptive purposes only and does not imply endorsement by the U.S. Government.

Although this report is in the public domain, permission must be secured from the individual copyright owners to reproduce any copyrighted materials contained within this report.

Suggested citation:

Loper, C.A., Breen, K.J., Zimmerman, T.M., and Clune, J.W., 2009, Pesticides in ground water in selected agricultural land-use areas and hydrogeologic settings in Pennsylvania, 2003-07: U.S. Geological Survey Scientific Investigations Report 2009-5139, 123 p. 


\section{Contents}

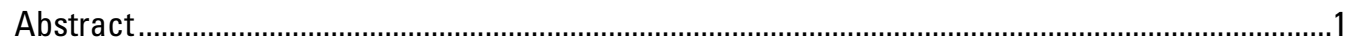

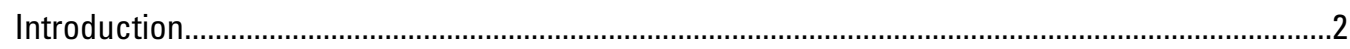

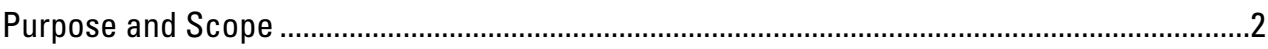

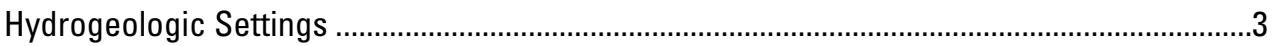

Patterns of Pesticide Use .................................................................................................

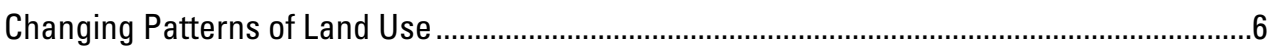

Previous Investigations with Emphasis on the Period 1997-2002 ..........................................6

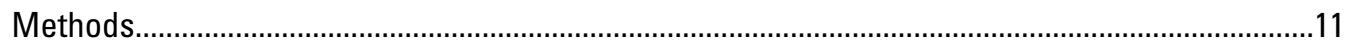

Baseline-Assessment Areas.............................................................................................11

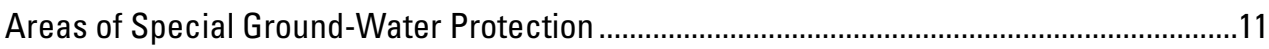

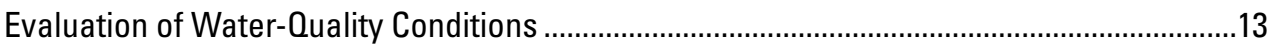

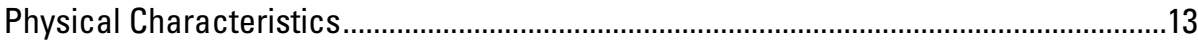

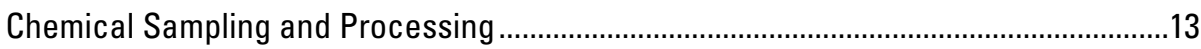

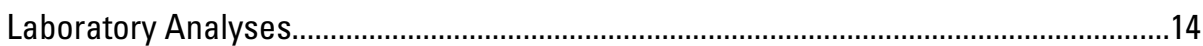

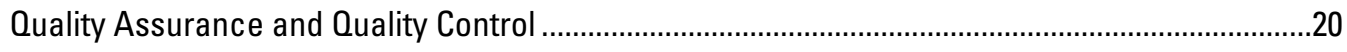

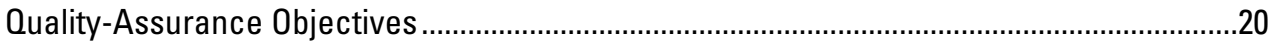

Qualifying Sample Results Based on Quality-Assurance Objectives ..................................23

Pesticides in Ground Water for the Baseline Assessment of Hydrogeologic Settings, 2003-07...24

Blue Ridge Crystalline and Triassic Lowland Siliciclastic ..................................................2

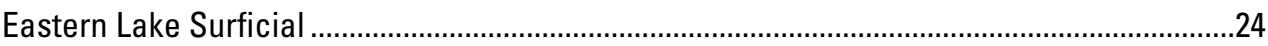

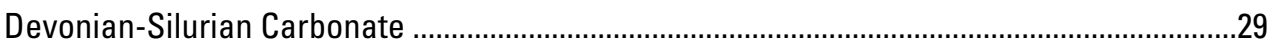

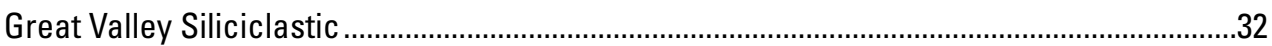

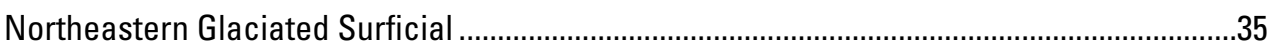

Correlating Pesticide 0ccurrence with Other Indicators of Water-Quality Degradation ................38

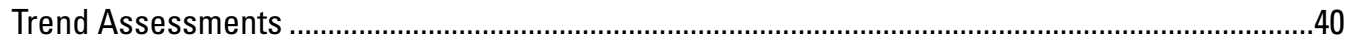

Pesticide Concentration Changes for Selected Wells in Baseline-Assessment Areas .........40

Pesticide and Nitrate Concentration Changes for Three Hot-Spot Wells in Areas of Special Ground-Water Protection ............................................................................4

Pesticides and Pesticide-Degradation Products in Ground Water near Hot-Spot Wells ...............56

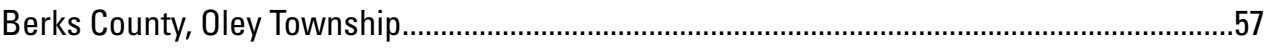

Blair County, North Woodbury Township...............................................................................

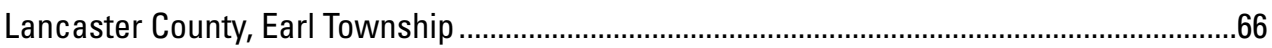

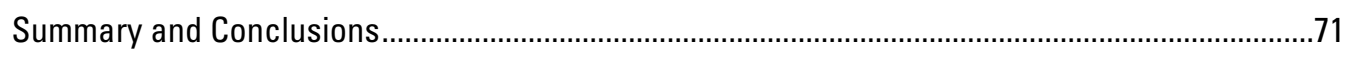

Changing Patterns of Pesticide Use Related to Land-Use Changes.....................................72

Investigations of Pesticides in Pennsylvania Ground Water, 1997-2002 …………................72

Quality Assurance and Quality Control ...............................................................................

Monitoring Data for Pesticide Occurrence, 2003-07 ..............................................................73

Patterns of Pesticide Concentration Change, 1993-2004 .....................................................74

Pesticides in Ground Waters Representing Three Areas of Special Ground-Water

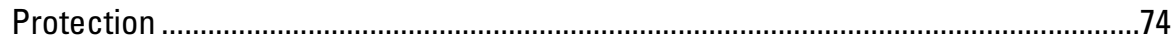

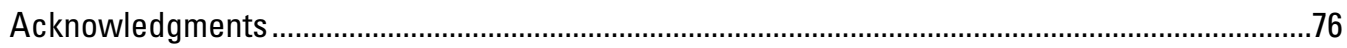

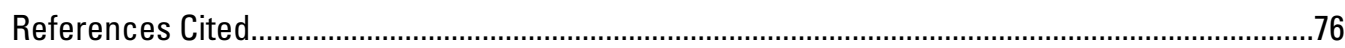


Appendix 1. Methods for Estimating Pesticide Use .................................................................94

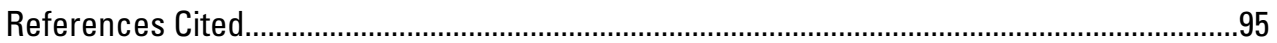

Appendix 2. Detailed Description of Quality-Control Methods and Data Analyses ......................96

Representativeness of Sampling of Hydrogeologic Settings ...................................................96

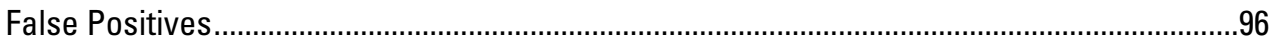

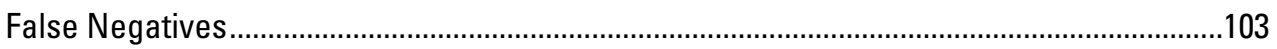

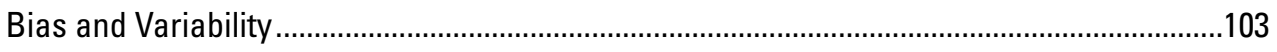

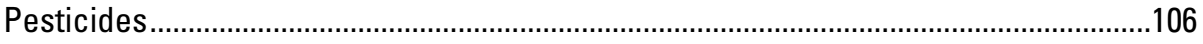

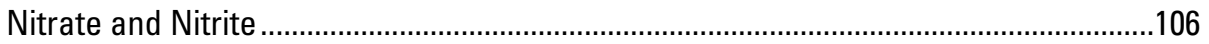

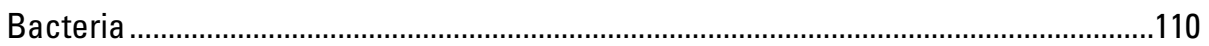

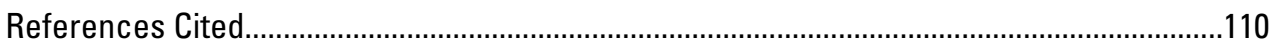

Appendix 3. List of Electronic Databases Used in This Report.................................................122

Appendix 4. Regulatory Information for Compounds Measured in This Study...........................123

\section{Figures}

1. Map showing hydrogeologic settings of Pennsylvania used for assessments of pesticides in ground water.

2-4. Graphs showing:

2. Acres harvested statewide in 2003-06 for Pennsylvania crop commodities likely produced with use of pesticides..

3. Annual use of pesticides in Pennsylvania, 2003-06, and a breakdown of use by crop for atrazine, metolachlor, and acetochlor. 5

4. Statewide use of selected pesticides on corn in 1996 and in 2004-05.

5. Map and graph showing atrazine use on corn crops for 66 Pennsylvania counties as A) chart comparing 1996 data and 2004-05 data, and B) map for 2004-05 data for three use-per-year categories

6. Graphs showing pesticide use on corn crops for 66 Pennsylvania counties in 1996 and in 2004-05 for $A$ ) acetochlor, and $B$ ) metolachlor plus S-metolachlor.

7-12. Maps showing:

7. Locations of hot-spot wells sampled in areas of special ground-water protection, Berks, Blair, and Lancaster Counties, Pennsylvania, March 2003 to August 2007.

8. Locations of wells sampled for pesticide analysis and wells with reported concentrations above the minimum reporting levels in the Blue Ridge crystalline and Triassic Lowland siliciclastic hydrogeologic setting, Adams and Cumberland Counties, Pennsylvania, May and August 2003..

9. Locations of wells sampled for pesticide analysis in the Eastern Lake surficial hydrogeologic setting, Erie County, Pennsylvania, May-October 2004

10. Locations of wells sampled for pesticide analysis and wells with reported concentrations above the minimum reporting levels in the Devonian-Silurian carbonate hydrogeologic setting of Pennsylvania, June-August 2005

11. Locations of wells sampled for pesticide analysis and wells with reported concentrations above the minimum reporting levels in the Great Valley siliciclastic hydrogeologic setting of Pennsylvania, June-August 2006. 
12. Locations of wells sampled for pesticide analysis and wells with reported concentrations above the minimum reporting levels in the Northeastern Glaciated surficial hydrogeologic setting of Pennsylvania,

May-September 2007

13. Contingency table $(2 \times 2)$ and one-sided $p$-values resulting from Fischer's Exact Test for the same or stronger associations from four hydrogeologic settings, Pennsylvania, 2003 and 2005-07, to determine relation of presence or absence of pesticides and presence or absence of total coliform bacteria in ground-water samples

14-15. Graphs showing:

14. The relation between numbers of pesticides above the minimum reporting level and nitrate concentration in well-water samples collected in the Devonian-Silurian carbonate, Great Valley siliciclastic, and Northeastern Glaciated surficial hydrogeologic settings of Pennsylvania

15. The relation between concentrations of atrazine and nitrate in well-water samples collected in the Devonian-Silurian carbonate, Great Valley siliciclastic, and Northeastern Glaciated surficial hydrogeologic settings of Pennsylvania

16. Map showing locations of wells sampled for this project and the National Water-Quality Assessment (NAWQA) project.

17. Graphs showing data for nine wells in agricultural row-crop settings underlain by carbonate bedrock, Lower Susquehanna River Basin, Pennsylvania, from a one-time sample from those wells in 1993-95 and a sample in 2003 for $A$ ) water level, $B$ ) concentration of atrazine, and $C$ ) concentration of CIAT (deethylatrazine), a breakdown product of atrazine.

18. Boxplots showing range of $A$ ) atrazine concentrations 1993-95 (one-time sample) compared to 2003 with results of Tukey-Kramer multiple-comparison test and $B$ ) paired differences in atrazine concentrations 2003 minus 1993-95 for nine wells in agricultural row-crop setting underlain by carbonate bedrock, Lower Susquehanna River Basin, Pennsylvania ......

19-22. Graphs showing:

19. Concentrations of alachlor, metolachlor, and atrazine in samples collected from 1998 to 2007 at well BE 1370, Oley Township, Berks County, Pennsylvania....47

20. Concentrations of alachlor, metolachlor, and atrazine in samples collected from 1996 to 2007 at well BA 437, North Woodbury Township, Blair County, Pennsylvania

21. Concentrations of acetochlor, alachlor, metolachlor, and atrazine in samples collected from 1995 to 2007 at well LN 1842, Earl Township, Lancaster County, Pennsylvania

22. Nitrate concentrations in 1996-2007 for samples collected at wells BA 437, LN 1842, and BE 1370 in Pennsylvania

23. Boxplots showing range of alachlor concentrations from 2003 to 2007 by season at well BA 437, North Woodbury Township, Blair County, Pennsylvania, and results of Tukey-Kramer multiple-comparison test

24-26. Maps showing:

24. Locations of well BE 1370, five neighboring wells, and a spring, Oley Township, Berks County, Pennsylvania.

25. Locations of well BA 437 and five neighboring wells, North Woodbury Township and Borough of Martinsburg, Blair County, Pennsylvania ..

26. Locations of well LN 1842 and five neighboring wells, Earl Township and Borough of New Holland, Lancaster County, Pennsylvania 


\section{Tables}

1. Physiographic provinces, physiographic sections, and change in dominant land covers for selected hydrogeologic settings in Pennsylvania using 1992 and 2001 National Land Cover Databases...

2. Six U.S. Geological Survey investigations of major-use pesticides in ground water of Pennsylvania, 1997-2002, where data quality assurance could be documented .......10

3. Records of wells sampled for assessments of pesticides in ground water from baseline-assessment areas and areas of special ground-water protection, 2003-07, Pennsylvania. ...at back of report

4. Physical characteristics, units, accuracies, and equipment types used for this study...

5. Laboratories used for analytical work by analysis type and date of sample collection. 15

6. Pesticides analyzed at the Pennsylvania Department of Environmental Protection Laboratory (PADEPL) in Harrisburg, Pennsylvania, from August 2003 to December 2004

7. Pesticides analyzed using C-18 solid-phase extraction and capillary-column gas chromatography/mass spectrometry with selected-ion monitoring at the U.S. Geological Survey National Water Quality Laboratory in Denver, Colorado, from March to May 2003 and May 2005 to September 2007.

8. Pesticides analyzed using graphitized carbon-based solid-phase extraction and high-performance liquid chromatography/mass spectrometry at the U.S. Geological Survey National Water Quality Laboratory in Denver, Colorado, in May 2003.

9. Acetamide, triazine, and phenylurea pesticides and degradation products analyzed using solid-phase extraction and liquid chromatography/mass spectrometry at the U.S. Geological Survey Organic Geochemistry Research Laboratory (OGRL) in Lawrence, Kansas, from August to September 2005 and June 2006

10. Quality-control acceptance criteria for field-instrument calibration.

11. Summary of the numbers of quality-control samples analyzed at the U.S.

Geological Survey (USGS) National Water Quality Laboratory (NWOL), USGS Ohio Water Microbiology Laboratory (OWML), the USGS Organic Geochemistry Research Laboratory (OGRL), and the Pennsylvania Department of Environmental Protection Laboratory (PADEPL), 2003-07

12. Numbers of samples with no pesticides detected below the minimum reporting level and with concentrations of pesticides detected in samples collected in subareas of the Blue Ridge crystalline and Triassic Lowland siliciclastic hydrogeologic setting of Pennsylvania, 2003.

13. Local well numbers and concentrations of pesticides in samples collected in subareas of the Blue Ridge crystalline and Triassic Lowland siliciclastic hydrogeologic setting of Pennsylvania, 2003.

14. Number of samples with no pesticides detected below the minimum reporting levels and with concentrations of pesticides detected in samples collected in the Devonian-Silurian carbonate hydrogeologic setting of Pennsylvania, 2005

15. Local well numbers and concentrations of pesticides in samples collected in the Devonian-Silurian carbonate hydrogeologic setting of Pennsylvania, 2005.

16. Number of samples with no pesticides detected below the minimum reporting levels and with concentrations of pesticides detected in samples collected in the Great Valley siliciclastic hydrogeologic setting of Pennsylvania, 2006. 
17. Local well numbers and concentrations of pesticides in samples collected in the Great Valley siliciclastic hydrogeologic setting of Pennsylvania, 2006.

18. Numbers of samples with no pesticides detected below the minimum reporting levels and with concentrations of pesticides detected in samples collected in the Northeastern Glaciated surficial hydrogeologic setting of Pennsylvania, 2007.

19. Local well numbers and concentrations of pesticides in samples collected in the Northeastern Glaciated surficial hydrogeologic setting of Pennsylvania, 2007

20. Wells selected for a trend network in baseline-assessment areas

21. Pesticide co-occurrence in ground water collected at well BE 1370, Oley Township, Berks County, Pennsylvania, from 1998 to 2007.

22. Pesticide co-occurrence in ground water collected at well BA 437, North

Woodbury Township, Blair County, Pennsylvania, from 1996 to 2007

23. Pesticide co-occurrence in ground water collected at well LN 1842, Earl Township, Lancaster County, Pennsylvania, from 1995 to 2007

24. Trends in concentrations of selected pesticides and nitrate in hot-spot wells BA 437, LN 1842, and BE 1370 in Pennsylvania

25. Within-season analysis of long-term trends in concentrations of selected pesticides and nitrate in hot-spot wells BA 437, LN 1842, and BE 1370 in Pennsylvania using the Mann-Kendall test for trend.

26. Summary of selected well and water-quality characteristics with associated numbers of pesticide parent compounds and numbers of pesticide degradates in water from well BE 1370, five neighboring wells, and a spring, Oley Township, Berks County, Pennsylvania, August 18-23, 2005..

27. Concentrations of acetamide pesticides and degradation products in water from well BE 1370, five neighboring wells, and a spring, Oley Township, Berks County, Pennsylvania, August 18-23, 2005

28. Concentrations of triazine and phenylurea pesticides and degradation products in water from well BE 1370, five neighboring wells, and a spring, Oley Township, Berks County, Pennsylvania, August 18-23, 2005..

29. Summary of selected well and water-quality characteristics with associated numbers of pesticide parent compounds and numbers of pesticide degradates in water from well BA 437 and five neighboring wells, North Woodbury Township and Borough of Martinsburg, Blair County, Pennsylvania, August 30 through September 8, 2005.

30. Concentrations of acetamide pesticides and degradation products in water from well BA 437 and five neighboring wells, North Woodbury Township and Borough of Martinsburg, Blair County, Pennsylvania, August 30 through September 8, 2005 ......64

31. Concentrations of triazine and phenylurea pesticides and degradation products in water from well BA 437 and five neighboring wells, North Woodbury Township and Borough of Martinsburg, Blair County, Pennsylvania, August 30 through September 8, 2005.

32. Summary of selected well and water-quality characteristics with associated numbers of pesticide parent compounds and numbers of pesticide degradates in water from well LN 1842 and five neighboring wells, Earl Township and Borough of New Holland, Lancaster County, Pennsylvania, June 1 through June 29, 2006.

33. Concentrations of acetamide pesticides and degradation products in water from well LN 1842 and five neighboring wells, Earl Township and Borough of New Holland, Lancaster County, Pennsylvania, June 1 through June 29, 2006

34. Concentrations of triazine and phenylurea pesticides and degradation products in water from well LN 1842 and five neighboring wells, Earl Township and Borough of New Holland, Lancaster County, Pennsylvania, June 1 through June 29, 2006. 


\section{Conversion Factors}

\begin{tabular}{|c|c|c|}
\hline Multiply & By & To obtain \\
\hline \multicolumn{3}{|c|}{ Length } \\
\hline inch (in.) & 2.54 & centimeter $(\mathrm{cm})$ \\
\hline inch (in.) & 25.4 & millimeter (mm) \\
\hline foot (ft) & 0.3048 & meter $(\mathrm{m})$ \\
\hline mile (mi) & 1.609 & kilometer $(\mathrm{km})$ \\
\hline \multicolumn{3}{|c|}{ Area } \\
\hline acre & 4,047 & square meter $\left(\mathrm{m}^{2}\right)$ \\
\hline acre & 0.4047 & hectare (ha) \\
\hline acre & 0.4047 & square hectometer $\left(\mathrm{hm}^{2}\right)$ \\
\hline acre & 0.004047 & square kilometer $\left(\mathrm{km}^{2}\right)$ \\
\hline square mile $\left(\mathrm{mi}^{2}\right)$ & 259.0 & hectare (ha) \\
\hline square mile $\left(\mathrm{mi}^{2}\right)$ & 2.590 & square kilometer $\left(\mathrm{km}^{2}\right)$ \\
\hline \multicolumn{3}{|c|}{ Volume } \\
\hline gallon (gal) & 3.785 & liter (L) \\
\hline gallon (gal) & 0.003785 & cubic meter $\left(\mathrm{m}^{3}\right)$ \\
\hline gallon (gal) & 3.785 & cubic decimeter $\left(\mathrm{dm}^{3}\right)$ \\
\hline \multicolumn{3}{|c|}{ Flow rate } \\
\hline cubic foot per second $\left(\mathrm{ft}^{3} / \mathrm{s}\right)$ & 0.02832 & cubic meter per second $\left(\mathrm{m}^{3} / \mathrm{s}\right)$ \\
\hline $\begin{array}{l}\text { cubic foot per second per square } \\
\text { mile }\left[\left(\mathrm{ft}^{3} / \mathrm{s}\right) / \mathrm{mi}^{2}\right]\end{array}$ & 0.01093 & $\begin{array}{l}\text { cubic meter per second per square } \\
\text { kilometer }\left[\left(\mathrm{m}^{3} / \mathrm{s}\right) / \mathrm{km}^{2}\right]\end{array}$ \\
\hline cubic foot per day $\left(\mathrm{ft}^{3} / \mathrm{d}\right)$ & 0.02832 & cubic meter per day $\left(\mathrm{m}^{3} / \mathrm{d}\right)$ \\
\hline gallon per minute (gal/min) & 0.06309 & liter per second $(\mathrm{L} / \mathrm{s})$ \\
\hline \multicolumn{3}{|c|}{ Mass } \\
\hline ounce, avoirdupois (oz) & 28.35 & $\operatorname{gram}(\mathrm{g})$ \\
\hline pound, avoirdupois (lb) & 0.4536 & kilogram $(\mathrm{kg})$ \\
\hline \multicolumn{3}{|c|}{ Application rate } \\
\hline $\begin{array}{l}\text { pounds per acre per year } \\
{[(\mathrm{lb} / \mathrm{acre}) / \mathrm{yr}]}\end{array}$ & 1.121 & $\begin{array}{l}\text { kilograms per hectare per year } \\
{[(\mathrm{kg} / \mathrm{ha}) / \mathrm{yr}]}\end{array}$ \\
\hline pounds per year (lb/yr) & 0.4536 & kilograms per year $(\mathrm{kg} / \mathrm{yr})$ \\
\hline
\end{tabular}

Temperature in degrees Celsius $\left({ }^{\circ} \mathrm{C}\right)$ may be converted to degrees Fahrenheit $\left({ }^{\circ} \mathrm{F}\right)$ as follows:

${ }^{\circ} \mathrm{F}=\left(1.8 x^{\circ} \mathrm{C}\right)+32$

Vertical coordinate information is referenced to the North American Vertical Datum of 1988 (NAVD 88).

Horizontal coordinate information is referenced to the North American Datum of 1983 (NAD 83).

Altitude, as used in this report, refers to distance above the vertical datum.

Specific conductance is given in microsiemens per centimeter at 25 degrees Celsius $(\mu \mathrm{S} / \mathrm{cm}$ at $\left.25^{\circ} \mathrm{C}\right)$.

Concentrations of chemical constituents in water are given either in milligrams per liter (mg/L) or micrograms per liter $(\mu \mathrm{g} / \mathrm{L})$. 


\section{Abbreviations}

\begin{tabular}{|c|c|}
\hline CAAT & 2-chloro-4-isopropylamino-6-amino-s-triazine, deethyldeisopropylatrazine \\
\hline CEAT & 2-chloro-6-ethylamino-4-amino-s-traizine, deisopropylatrazine \\
\hline CIAT & 2-chloro-4-isopropylamino-6-amino-s-triazine, deethylatrazine \\
\hline DCPA & dimethyl-2,3,5,6-tetrachlorobenzene-1,4-dicarboxylic acid, dacthal \\
\hline DMFM & demethylfluometuron \\
\hline EPTC & s-ethyl dipropylthiocarbamate \\
\hline ESA & ethane sulfonic acid \\
\hline ESA SA & ethane sulfonic acid second amide \\
\hline FSRW & field-spiked reagent water \\
\hline GC & gas chromatography \\
\hline GCMS & gas chromatography/mass spectrometry \\
\hline GIS & Geographic Information System \\
\hline GWSI & Ground-Water Site Inventory \\
\hline $\mathrm{HCH}$ & hexachlorocyclohexane \\
\hline HPLC & high-performance liquid chromatography \\
\hline HPLCMS & high-performance liquid chromatography/mass spectrometry \\
\hline LHA & lifetime health advisory \\
\hline LRS & lab reagent spike \\
\hline MCPA & 2-methyl-4-chlorophenoxyacetic acid \\
\hline MCPB & 4-(2-methyl-4-chlorophenoxy) butyric acid \\
\hline MDL & method detection limit \\
\hline MRL & minimum reporting level \\
\hline $\mathrm{N}$ & nitrogen \\
\hline NTU & nephelometric turbidity unit \\
\hline NWIS & National Water Information System \\
\hline NWQL & National Water Quality Laboratory \\
\hline OEAT & deisopropylhydroxyatrazine \\
\hline OGRL & Organic Geochemistry Research Laboratory \\
\hline OIAT & deethylhydroxyatrazine \\
\hline OIET & hydroxyatrazine \\
\hline OWML & Ohio Water Microbiology Laboratory \\
\hline OXA & oxanilic acid \\
\hline p,p'-DDE & p,p'-dichlorodiphenyldichloroethylene \\
\hline PADEPL & Pennsylvania Department of Environmental Protection Laboratory \\
\hline
\end{tabular}




$\begin{array}{ll}\text { PATGS } & \text { Pennsylvania Topographic and Geologic Survey } \\ \text { PA WSC } & \text { Pennsylvania Water Science Center } \\ \text { PDA } & \text { Pennsylvania Department of Agriculture } \\ \text { PPGWS } & \text { Pennsylvania Pesticides and Ground Water Strategy } \\ \text { QA } & \text { quality assurance } \\ \text { QC } & \text { quality control } \\ \text { QAPP } & \text { quality assurance project plan } \\ \text { RSD } & \text { relative standard deviation } \\ \text { RPA } & \text { Rhone Poulenc Agro (Kim Morris, Bayer Crop Science, oral commun., Dec. 2008) } \\ \text { SAA } & \text { sulfynil acetic acid } \\ \text { SD } & \text { standard deviation } \\ \text { SRWS } & \text { standard reference water sample (prepared by Branch of Quality Systems, USGS) } \\ \text { USEPA } & \text { U.S. Environmental Protection Agency } \\ \text { USGS } & \text { U.S. Geological Survey }\end{array}$




\title{
Pesticides in Ground Water in Selected Agricultural Land-Use Areas and Hydrogeologic Settings in Pennsylvania, 2003-07
}

\author{
By Connie A. Loper, Kevin J. Breen, Tammy M. Zimmerman, and John W. Clune
}

\section{Abstract}

This report was prepared by the U.S. Geological Survey (USGS) in cooperation with the Pennsylvania Department of Agriculture (PDA) as part of the Pennsylvania Pesticides and Ground Water Strategy (PPGWS). Monitoring data and extensive quality-assurance data on the occurrence of pesticides in ground water during 2003-07 are presented and evaluated; decreases in the land area used for agriculture and corresponding changes in the use of pesticides also are documented. In the Pennsylvania ground waters assessed since 2003, concentrations of pesticides did not exceed any maximum contaminant or health advisory levels established by the U.S. Environmental Protection Agency; PPGWS actions are invoked by the PDA at fractions of these levels and were needed only in areas designated by the PDA for special ground-water protection.

Previous investigations through 1998 of pesticides in Pennsylvania ground water identified land use, as a surrogate for pesticide use, and rock type of the aquifer combined with physiography as key hydrogeologic setting variables for understanding aquifer vulnerability to contamination and the common occurrence of atrazine and metolachlor in ground water. Of 20 major hydrogeologic settings in a framework established in 1999 for pesticide monitoring in Pennsylvania, 9 were identified as priorities for data collection in order to change the monitoring status from "inadequate" to "adequate" for the PPGWS.

Agricultural and forested land-use areas are decreasing because of urban and suburban growth. In the nine hydrogeologic settings evaluated using 1992 and 2001 data, decreases of up to 12 percent for agricultural land and 10 percent for forested land corresponded to increases of up to 11 percent for urban land. Changes in agricultural pesticide use were computed from crop data. For example, from 1996 to 2004-05, atrazine use declined by about 15 percent to $1,314,000 \mathrm{lb} / \mathrm{yr}$ (pounds per year) and metolachlor use increased by about 20 percent to $895,000 \mathrm{lb} / \mathrm{yr}$; these compounds are the two most-used agricultural pesticides statewide.

In 2003-07, a baseline assessment of pesticides was conducted in five of nine hydrogeologic settings with inadequate monitoring data - the Blue Ridge crystalline and Triassic Lowland siliciclastic, Eastern Lake surficial, Devonian-Silurian carbonate, Great Valley siliciclastic, and Northeastern Glaciated surficial settings. Between 20 and 30 wells in each setting were monitored. Of the 126 wells sampled, 96 well-water samples were analyzed for at least 52 pesticide compounds at the USGS National Water Quality Laboratory (NWQL) using a method with a minimum reporting level (MRL) at or above $0.002 \mu \mathrm{g} / \mathrm{L}$ (micrograms per liter). Of the 96 well waters analyzed by NWQL, 43 had measureable concentrations of one or more pesticides. Atrazine and (or) deethylatrazine (CIAT), a degradation product of atrazine, were reported at or above the MRL in 39 of the 43 well waters. Neither atrazine nor CIAT were reported at concentrations exceeding $0.10 \mu \mathrm{g} / \mathrm{L}$; all measured concentrations in these five settings were below PPGWS action levels. Metolachlor was present in 7 of the 43 well waters with measureable concentrations of 1 or more pesticides; however, concentrations were below the MRL. The other 30 samples ( 10 of 20 wells in the Blue Ridge crystalline and Triassic Lowland siliciclastic setting and all 20 wells in the Eastern Lake surficial setting) were analyzed for at least 19 pesticide compounds at the Pennsylvania Department of Environmental Protection Laboratory (PADEPL); the PADEPL reported no concentrations of pesticides at or above an MRL of $0.10 \mu \mathrm{g} / \mathrm{L}$.

Statistical tests using the NWQL analytical results showed correlations between pesticide occurrence and two indicators of water-quality degradation - the occurrence of total coliform bacteria and nitrate concentration. A $2 \times 2$ contingency-table test indicated a relation between presence or absence of atrazine or metolachlor and presence or absence of bacteria only for the 10 wells representing the Blue Ridge crystalline and Triassic Lowland siliciclastic setting. Results of Spearman's rank test showed strong positive correlations in the Devonian-Silurian carbonate setting between 1) the number of pesticides above the MRLs and nitrate concentration, and 2) concentrations of atrazine and nitrate. Atrazine concentration and nitrate concentration also showed a statistically significant positive correlation in the Great Valley siliciclastic setting. 
An additional component of baseline monitoring was to evaluate changes in pesticide concentration in water from wells representing hydrogeologic settings most vulnerable to contamination from pesticides. In 2003, 16 wells originally sampled in the 1990s were resampled - 4 each in the Appalachian Mountain carbonate, Triassic Lowland siliciclastic, Great Valley carbonate, and Piedmont carbonate settings. Nine of these wells, where pesticide concentrations from 1993 and 2003 were analyzed at the NWQL, were chosen for a paired-sample analysis using concentrations of atrazine and metolachlor. A statistically significant decrease in atrazine concentration was identified using the Wilcoxon signed-rank test $(p=0.004)$; significant temporal changes in metolachlor concentrations were not observed $(p=0.625)$.

Monitoring in three areas of special ground-water protection, where selected pesticide concentrations in well water were at or above the PPGWS action levels, was done at wells BE 1370 (Berks County, Oley Township), BA 437 (Blair County, North Woodbury Township), and LN 1842 (Lancaster County, Earl Township). Co-occurrence of pesticide-degradation products with parent compounds was documented for the first time in ground-water samples collected from these three wells. Degradation products of atrazine, cyanazine, acetochlor, alachlor, and metolachlor were commonly at larger concentrations than the parent compound in the same water sample. Pesticide occurrence in water from wells neighboring the hot-spot wells was highly variable; however, the same sets of pesticide compounds that were present in wells BA 437, BE 1370, and LN 1842 were present to some degree in water from neighboring wells. To evaluate temporal changes in concentration, nonparametric statistical tests were used to determine overall and seasonal monotonic trends. Concentrations of alachlor, atrazine, metolachlor, and nitrate were examined using the 5-year (2003-07) and the long-term data from wells BA 437 and LN 1842 (1996-2007 and 1995-2007, respectively), and the long-term data for well BE 1370 (1998-2007); results showed either downward trends or no trends. Trends in acetochlor concentrations were tested only at well LN 1842 using the 5-year data; no trends were observed. Homogeneity of trend tests indicated statistically significant downward concentration trends in the long-term data were due to seasonal trends as follows: BA 437-alachlor and atrazine (summer); BE 1370 - atrazine and metolachlor (winter) and alachlor (winter and spring); LN 1842 - alachlor (summer and fall) and atrazine (spring and fall).

\section{Introduction}

Pesticides are used to improve yields of agricultural crops throughout Pennsylvania. Use of pesticides also is common in urban and suburban areas statewide. The Pennsylvania Department of Agriculture (PDA) has regulatory authority for registration and use of all pesticide products. The PDA is also responsible for ensuring the application of pesticides does not contaminate Pennsylvania's ground-water resources. A draft Pennsylvania Pesticides and Ground Water Strategy (PPGWS) developed by the Pennsylvania Department of Agriculture (1998) outlines an approach for managing pesticides and preserving ground-water quality. The goal of this strategy is to protect all sources of drinking water from degradation. This strategy serves as a framework for the PDA to manage specific pesticides, as required by the U.S. Environmental Protection Agency (USEPA). The PPGWS specifies requirements for assessment of aquifer vulnerability and monitoring of pesticides in ground water.

As a result of detailed studies linking rock type and land use to pesticides in ground water (Lietman, 1997; Lindsey and others, 1998), monitoring for pesticides in Pennsylvania's ground water is structured with land use as a surrogate for pesticide use and rock type of the aquifer combined with physiography to establish "hydrogeologic setting" as a key design variable to represent vulnerability to pesticide contamination. Consistent with this structure, Lindsey and Bickford (1999) established a framework for characterizing the occurrence of pesticides in ground water throughout the state. Hydrogeologic settings previously assessed to a limited extent or not assessed at all and that were predominated by agricultural land use were given high priority for characterization studies. Agricultural row-crop areas were the focus of the statewide sampling design because the agricultural use of pesticides was substantial and was better defined than other uses. Hence, the focus of ground-water monitoring has been in rural areas where 1) pesticide applications are predominantly related to agriculture, and 2) rural residents obtain water supplies primarily from private household water wells.

PDA's responsibilities under the PPGWS are to establish pesticide-occurrence monitoring and assess for trends in pesticide concentrations for 1) areas of selected hydrogeologic settings vulnerable to pesticide contamination where baseline assessments of pesticide concentrations are needed (hereafter termed baseline-assessment areas) and 2) areas of special ground-water protection, defined as areas where concentrations of pesticides in ground water are at or above action levels specified in the PPGWS (wells in these areas are referred to as hot-spot wells). An investigation to address both monitoring responsibilities began in 2003 by the U.S. Geological Survey (USGS), in cooperation with the PDA.

\section{Purpose and Scope}

This report summarizes an investigation of pesticides in Pennsylvania ground water by presenting:

- Estimates of statewide and county pesticide use on agricultural crops for the mid-1990s and the study period 2003-07, and land-use estimates for 1992 and 2001 in nine hydrogeologic settings;

- A summary of previous investigations with an emphasis on 1997-2002; 
- Results of 126 analyses during 2003-07 to assess occurrence of pesticides in water from aquifers in baseline-assessment areas representing five selected hydrogeologic settings vulnerable to pesticide contamination and that were previously assessed to a limited extent or not assessed at all (the focus of the current study was on settings with row-crop agriculture; urban or suburban settings with non-agricultural use of pesticides, including transportation and power-line rightsof-way, were excluded);

- An evaluation of long-term changes in pesticide concentration for waters from nine wells in baselineassessment areas in each of four hydrogeologic settings vulnerable to pesticide contamination where concentrations of selected pesticides were compared to concentrations in water from the same wells measured approximately 10 years earlier;

- An evaluation of long-term changes in pesticide concentration for waters from wells in areas of special ground-water protection; these detailed investigations of pesticide occurrence, seasonal concentration change related to changing water levels, and persistence in areas of special ground-water protection in Berks, Blair, and Lancaster Counties involved three "hotspot" well locations (a well from each of the areas of special ground-water protection where selected pesticide concentrations in well water were at or above the PPGWS action levels) sampled in winter, spring, summer, and fall 2003-07.

- An examination of concentrations of 15 pesticides, 39 pesticide degradation products, and other indicators of water-quality degradation in water from wells neighboring the hot-spot wells in the three areas of special ground-water protection listed above. A total of 16 sites ( 15 wells and 1 spring) were sampled one time.

- An examination of concentrations of nitrate nitrogen, nitrite nitrogen, (henceforth referred to as nitrate and nitrite, respectively), and most probable numbers of total coliform and Escherichia coli (E. coli) bacteria as indicators of water-quality degradation and their correlation with pesticide results in baseline-assessment areas representing four selected hydrogeologic settings.

Because of the regulatory authority of the PDA related to pesticide use, quality control was extensive. Approximately 46 percent of all samples collected were for quality-control testing. An evaluation of bias and variability is presented on the basis of 191 quality-control (QC) samples (42 blanks, 58 replicates, 73 field-spiked reagent water [FSRW] samples, 6 standard reference water samples [SRWS], and 12 two-lab splits). The intent of the QC split samples analyzed at two laboratories (2-lab splits) was to verify the concentrations received from the primary laboratory used. Results from laboratory reagent spikes analyzed by both the PADEPL and the NWQL were also used as measures of QC.

\section{Hydrogeologic Settings}

The 20 hydrogeologic settings for assessment of pesticide occurrence in Pennsylvania ground water were defined and prioritized by Lindsey and Bickford (1999). Pesticide occurrence was assessed to a limited extent or not previously assessed at all in five hydrogeologic settings, which were selected for sampling in 2003-07. The five settings (fig. 1) included 1) an area straddling the boundary between the Blue Ridge crystalline and Triassic Lowland siliciclastic (assessed as one setting for this report), 2) Eastern Lake surficial, 3) Devonian-Silurian carbonate, 4) Great Valley siliciclastic, and 5) Northeastern Glaciated surficial. The Blue Ridge crystalline and the Triassic Lowland siliciclastic settings were considered one setting because of land use - an area straddling the two settings is characterized by the largest concentration of orchards in the state. Areas of row-crop agriculture (primarily corn and soybeans) were targeted for assessment except in settings 1 and 2, where orchards and vineyards, respectively, were major components of the agricultural activity.

\section{Patterns of Pesticide Use}

Statewide pesticide-use data were available for 2003-06. The major crop commodities that require substantial pesticide use are shown in figure 2 in order by the acres harvested. Corn was dominant in areal terms with an average of $1,375,000$ acres harvested over the 4 years. Annually, acres harvested did not vary substantially for any commodity shown in figure 2.

Annual pesticide use for agricultural purposes in Pennsylvania was estimated to 1) ensure the pesticides selected for ground-water sampling were in widespread use, and 2) determine if there were major changes in usage patterns from the mid-1990s to the period of this study (2003-07). The methods for estimating pesticide use for this report are presented in appendix 1. At the time data were compiled, no data was available for 2007; hence, data from 2003-06 were used to represent the period of this study. There were 134 pesticides used on Pennsylvania crops from 2003 to 2006 (U.S. Department of Agriculture National Agricultural Statistics Service, 2004, 2005a, 2006a, 2006b, 2007a, 2007b). Pesticide use amounted to greater than $14,000 \mathrm{lb} / \mathrm{yr}$ for each of 21 pesticides (fig. 3). Amounts of S-metolachlor and metolachlor were combined on figure 3 because of similar chemical structure and use. In a similar manner, glyphosate and the "iso-salt" of glyphosate also were combined on figure 3. Atrazine, metolachlor, and acetochlor were selected as representative triazine and acetamide compounds for focus in this study on the basis of heavy use and properties that can lead to contamination of water resources. Atrazine and metolachlor, 1,314,000 and $895,000 \mathrm{lb} / \mathrm{yr}$, respectively, were the most-used pesticides (primarily on field corn [grain and silage] and sweet corn, fig. 3). Acetochlor was introduced in 1994 as a possible replacement for alachlor (Kolpin and others, 2004) and atrazine. Current 


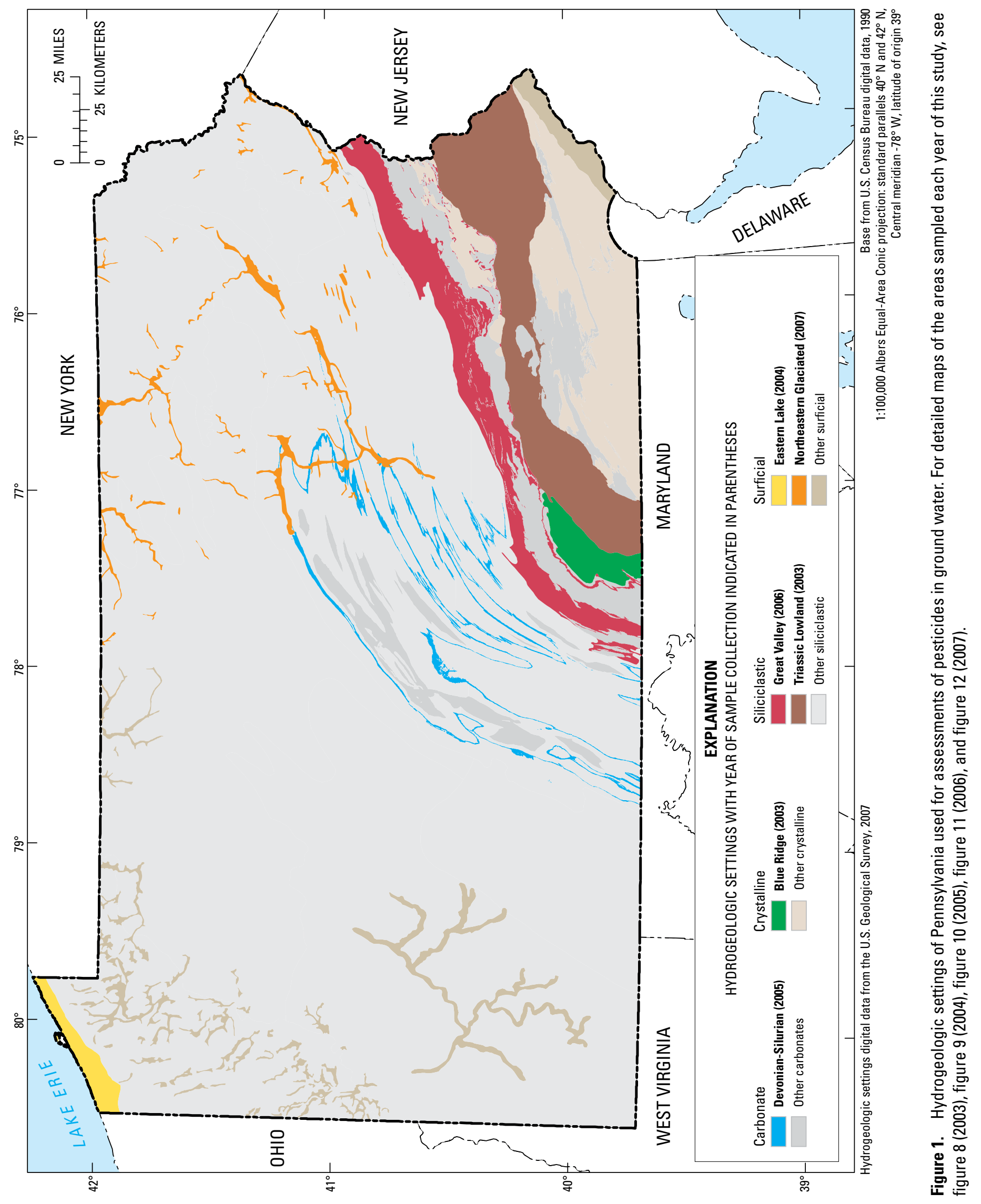




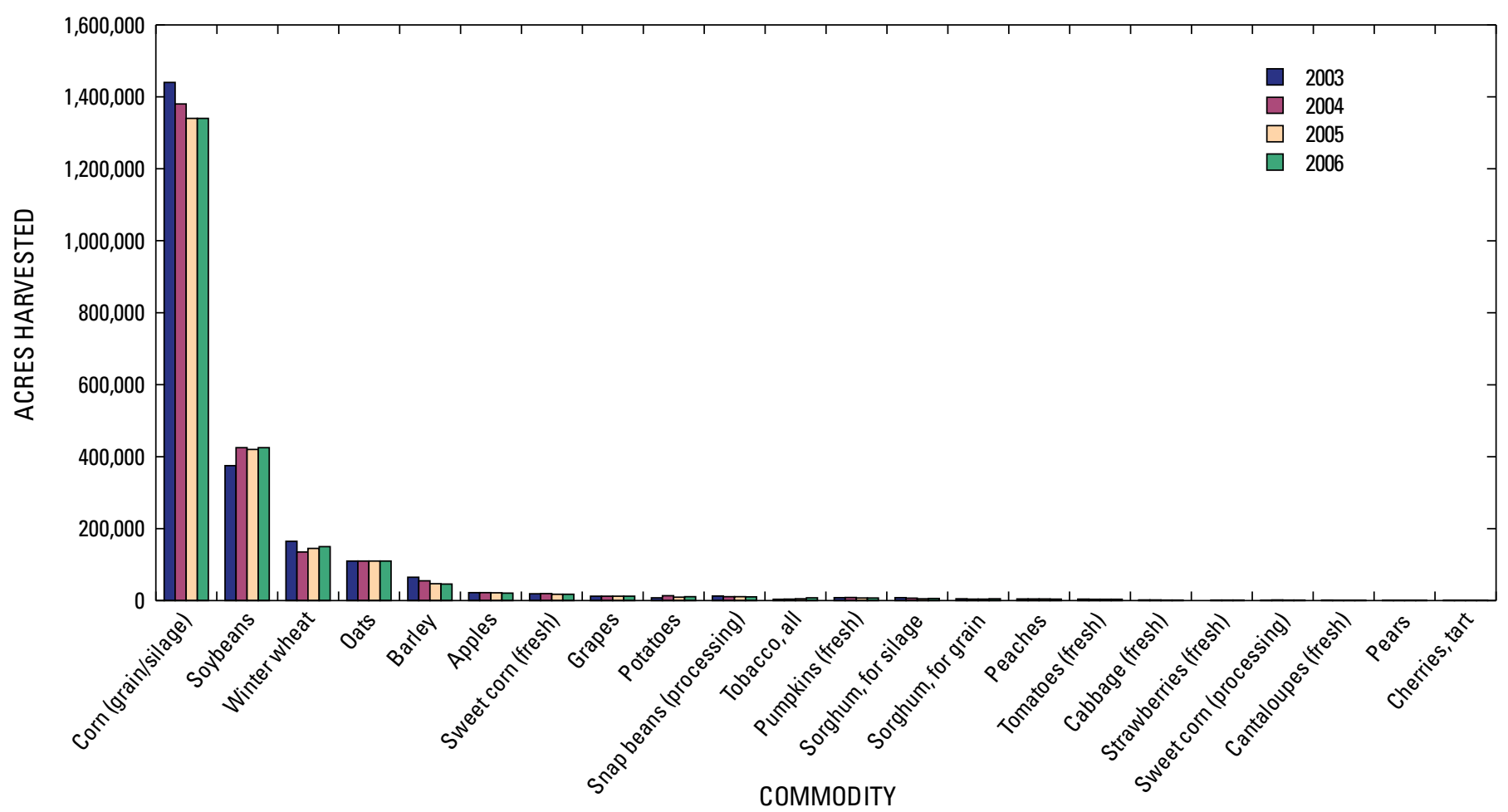

Figure 2. Acres harvested statewide in 2003-06 for Pennsylvania crop commodities likely produced with use of pesticides. Data obtained from the Pennsylvania Agricultural Statistics Bulletin for 2003-06 (Pennsylvania Department of Agriculture, 2004, 2005, 2006, 2007).

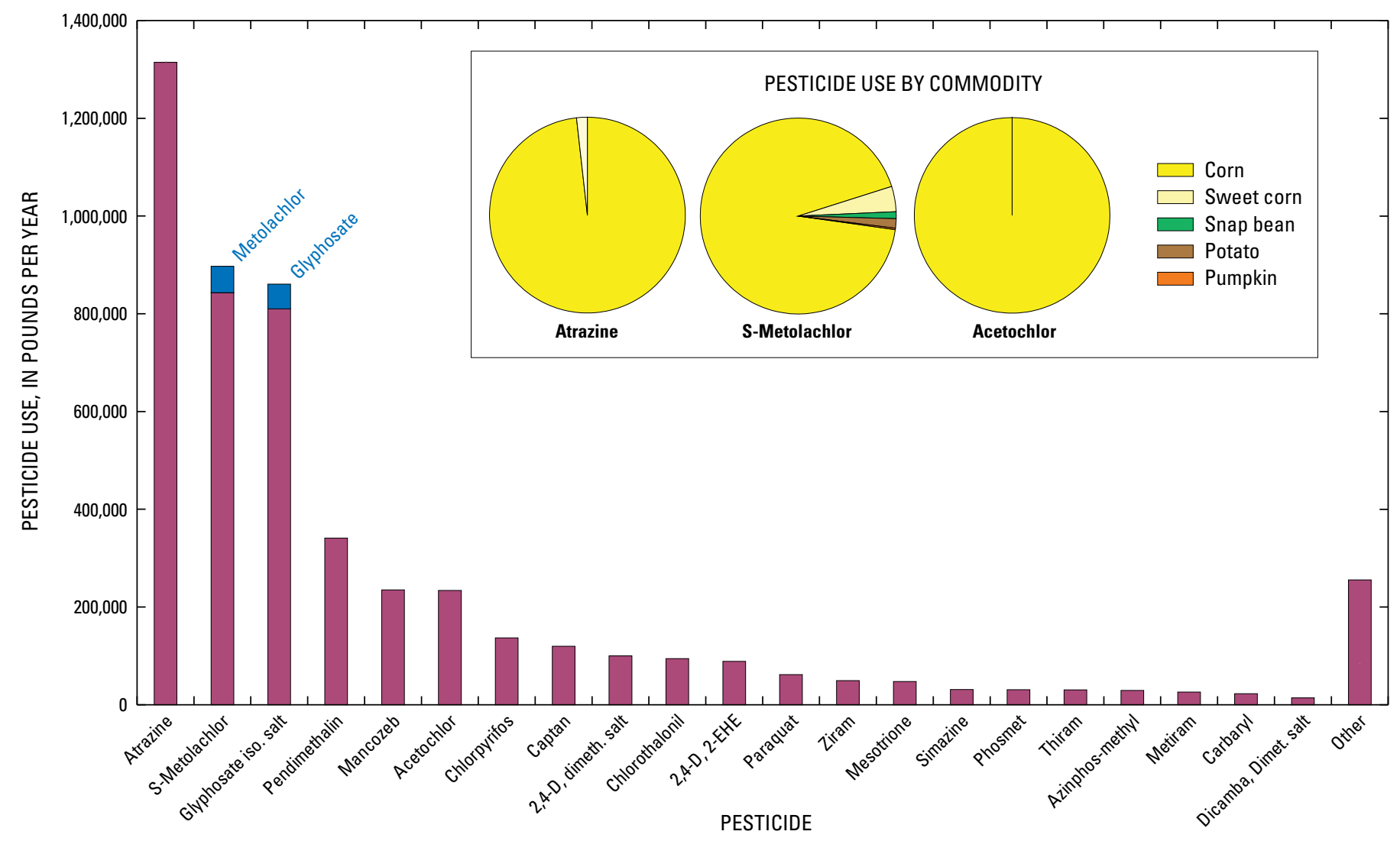

Figure 3. Annual use of pesticides in Pennsylvania, 2003-06, and a breakdown of use by crop commodity for atrazine, metolachlor, and acetochlor. [Based on acres of crop commodity planted for Pennsylvania (U.S. Department of Agriculture National Agricultural Statistics Service, 2004, 2005a, 2006a, 2006b, 2007a, 2007b) and not acres harvested.] 
(2006) acetochlor use is about $234,000 \mathrm{lb} / \mathrm{yr}$ statewide; acetochlor is used solely on corn (fig. 3). Compounds whose use in Pennsylvania has been terminated are not shown on figure 3 (for example, any existing stock of cyanazine was to be used by December 31, 2002; U.S. Environmental Protection Agency, 2000b).

Statewide use of atrazine, metolachlor, and acetochlor on corn crops in 1996 (field corn and sweet corn data were combined) and in 2004-05 (2004 data were for field corn and 2005 data were for sweet corn) is shown in figure 4. Pesticide use for selected pesticides on crops besides corn such as snap beans, potatoes, or pumpkins represents less than 3 percent of the crops to which atrazine, metolachlor, and acetochlor were applied. Atrazine use on corn decreased from 1,506,000 lb/yr in 1996 to 1,298,000 lb/yr in 2004-05, a decrease of about 13 percent. Metolachlor use increased from 725,000 to $852,000 \mathrm{lb} / \mathrm{yr}$, an increase of about 16 percent; S-metolachlor usage has largely replaced metolachlor over the past decade. Acetochlor use decreased from 507,000 lb/yr in 1996 to $237,000 \mathrm{lb} / \mathrm{yr}$ in $2004-05$, in part because of lower application rates, less area on which the pesticide is applied, and decreased acreage of harvested corn (table 1-1 in appendix 1)

Atrazine-use estimates are illustrated in figure $5 \mathrm{~A}$ by county for corn in 1996 (field corn and sweet corn data were combined) and in 2004-05 (2004 data were for field corn and 2005 data were for sweet corn); 2004-05 patterns in atrazine use by county in Pennsylvania are shown in figure 5B. Atrazine use decreased from 1996 to 2004 for 50 of 66 counties. Lancaster County accounted for 12.9 percent of all atrazine

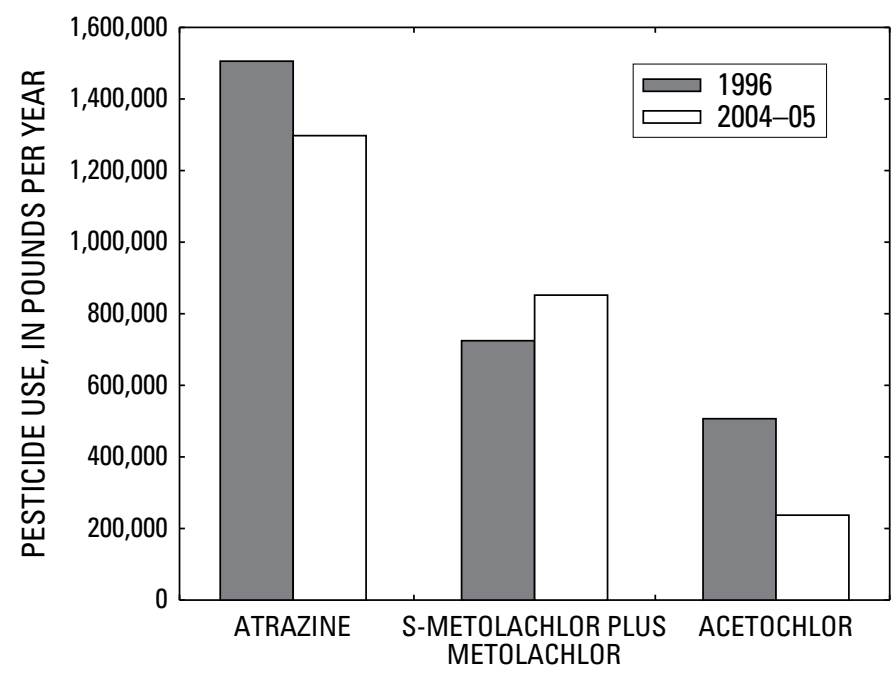

Figure 4. Statewide use of selected pesticides on corn in 1996 (field corn and sweet corn) and in 2004-05 (field corn data from 2004 plus sweet corn data from 2005). Use estimates are calculated on the basis of area of crop commodity harvested for Pennsylvania counties, in acres (Pennsylvania Department of Agriculture, 1997; U.S. Department of Agriculture National Agricultural Statistics Service, 1997a, 1997b, 2005a, 2005b, 2006a, 2006c). Methodology is presented in appendix 1. use (2004-05) in Pennsylvania. Lancaster County combined with eight other southeast counties (York, Franklin, Berks, Chester, Lebanon, Dauphin, Cumberland, and Adams) accounted for 40.7 percent of the atrazine use (2004-05) in Pennsylvania; those nine counties comprise 13.9 percent of the land area in Pennsylvania.

Acetochlor and metolachlor are not used as heavily as atrazine; however, acetochlor and metolachlor show similar patterns of use by county. Acetochlor use decreased from 1996 to $2004-05$ for 65 of 66 counties (fig. 6A), and metolachlor use on corn increased from 1996 to 2004-05 in 43 of 66 counties (fig. 6B).

\section{Changing Patterns of Land Use}

The National Land Cover Database 2001 (Multi-Resolution Land Characteristics, 2001) was compared to the National Land Cover Database 1992 (Multi-Resolution Land Characteristics, 1992) to quantify and relate changing patterns in three major land-cover categories (agriculture, forest, and urban) for nine hydrogeologic settings where agricultural land use was important historically (table 1). From 1992 to 2001 in the nine settings, agricultural land generally decreased up to 12 percent (median decrease 7.2 percent), forested land decreased up to 10 percent (median decrease 4.5 percent), and urban land increased up to 11 percent (median increase 2 percent).

\section{Previous Investigations with Emphasis on the Period 1997-2002}

Numerous investigations have contributed to the current knowledge of pesticide occurrence in Pennsylvania ground water. A compilation of investigations that analyzed for alachlor, atrazine, cyanazine, metolachlor, and simazine in ground water through 1998 was presented by Lindsey and Bickford (1999, p. 5). Investigations subsequent to the Lindsey and Bickford compilation and selected references to source data through 2002 are presented in table 2. Most are regional investigations by the USGS in the Delaware River Basin (see table 2 entries for USGS Delaware NAWQA [National Water-Quality Assessment] and USGS/PDA Delaware River Basin Quality Assurance Design). In addition to the data-source references provided in table 2, data were available in a compilation by Low and others (2008).

Primary findings of the previous investigations were 1) atrazine, metolachlor, and simazine are the three pesticide parent compounds reported most often in analyses of groundwater samples (concentrations are low with none exceeding USEPA drinking-water standards); 2) two or more compounds typically occur together and the health effects of co-occurring compounds are unknown; and 3) degradation products of the parent compounds typically have reported concentrations at or above the parent compounds; however, degradation products are not routinely measured in studies of ground-water quality, and applicable drinking-water standards are not established. 


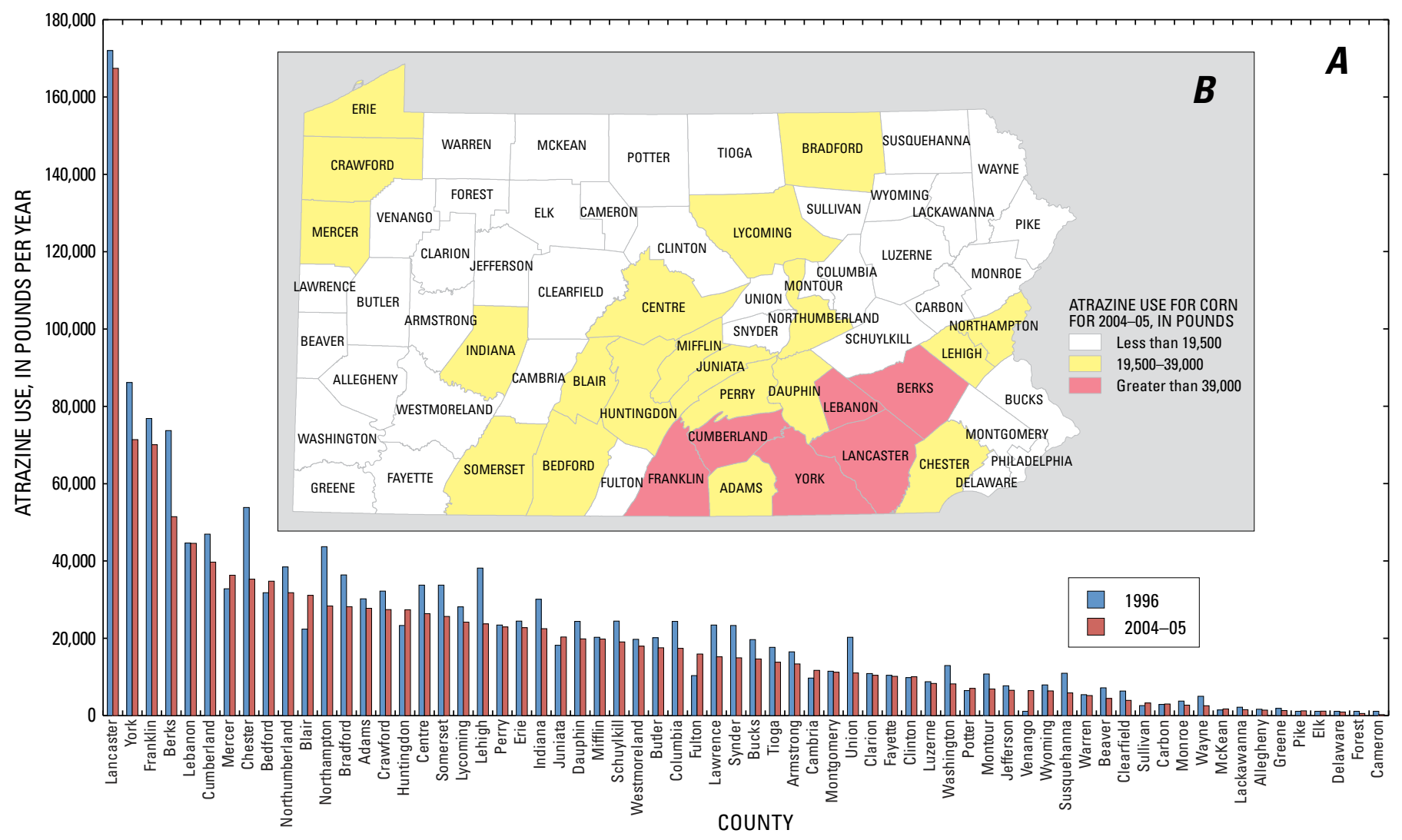

Figure 5. Atrazine use on corn crops for 66 Pennsylvania counties (no data for Philadelphia County) as A) chart comparing 1996 data (field corn and sweet corn) and 2004-05 data (field corn data from 2004 plus sweet corn data from 2005), and B) map for 2004-05 data for three use-per-year categories. Use estimates are calculated on the basis of area of crop commodity harvested for Pennsylvania counties, in acres (Pennsylvania Department of Agriculture, 1997; U.S. Department of Agriculture National Agricultural Statistics Service, 1997a, 1997b, 2005a, 2005b, 2006a, 2006c). 

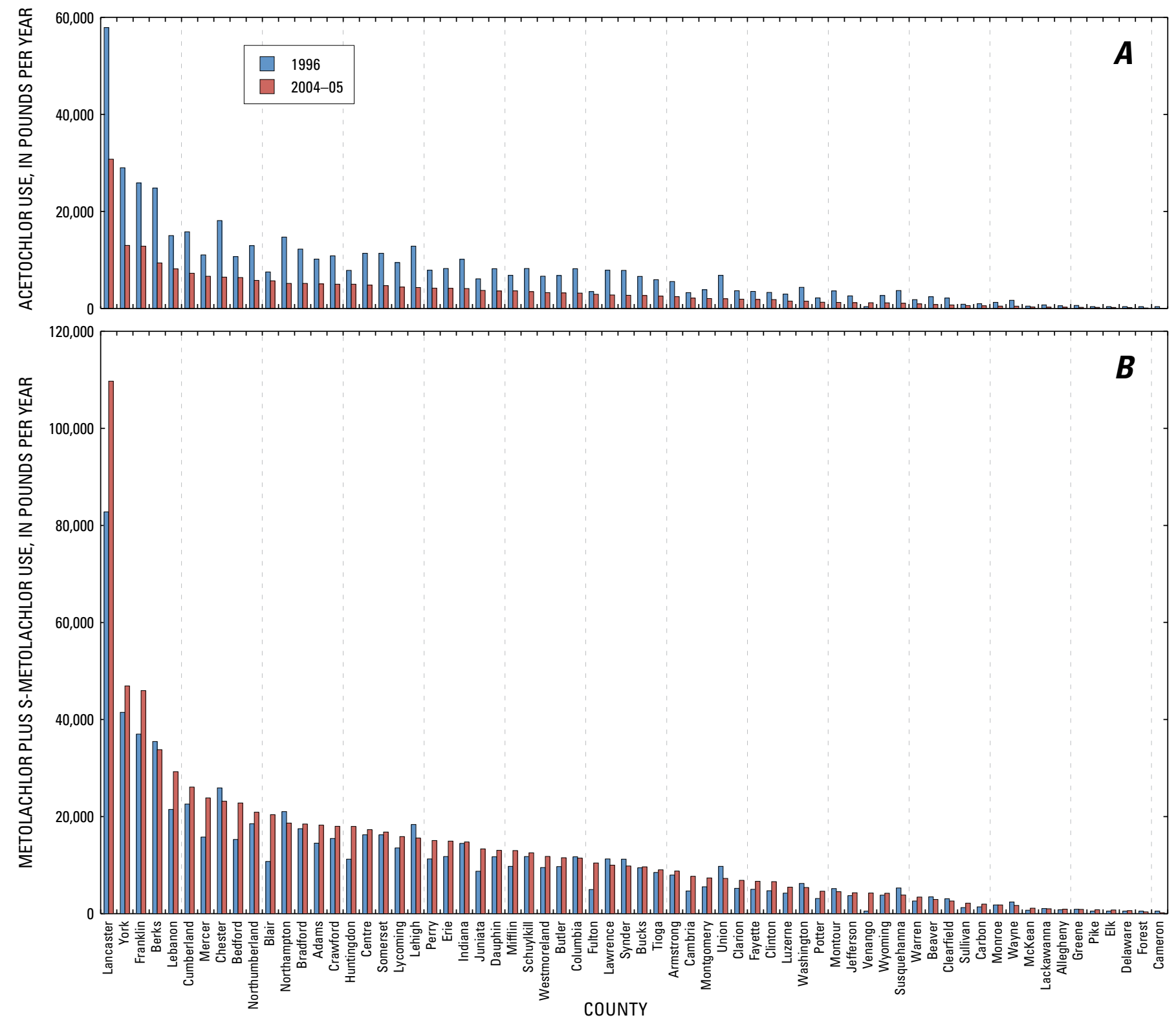

Figure 6. Pesticide use on corn crops for 66 Pennsylvania counties (Philadelphia County not shown) in 1996 (field corn and sweet corn) and in 2004-05 (field corn data from 2004 plus sweet corn from 2005) for $A$ ) acetochlor, and B) metolachlor plus S-metolachlor. Use estimates are calculated on the basis of area of crop commodity harvested for Pennsylvania counties, in acres (Pennsylvania Department of Agriculture, 1997; U.S. Department of Agriculture National Agricultural Statistics Service, 1997a, 1997b, 2005a, 2005b, 2006a, 2006c). 
Table 1. Physiographic provinces, physiographic sections, and change in dominant land covers for selected hydrogeologic settings in Pennsylvania using 1992 and 2001 National Land Cover Databases.

[NLCD, National Land Cover Database]

\begin{tabular}{|c|c|c|c|c|c|}
\hline $\begin{array}{l}\text { Hydrogeologic } \\
\text { setting }\end{array}$ & $\begin{array}{l}\text { Physiographic } \\
\text { province }^{1}\end{array}$ & $\begin{array}{l}\text { Physiographic } \\
\text { section }^{1}\end{array}$ & $\begin{array}{l}\text { Dominant } \\
\text { land } \\
\text { covers }^{2}\end{array}$ & $\begin{array}{c}\text { NLCD } \\
1992 \\
\text { (percent) }^{3}\end{array}$ & $\begin{array}{c}\text { NLCD } \\
2001 \\
\text { (percent) }^{4}\end{array}$ \\
\hline \multirow[t]{3}{*}{ Eastern Lake surficial } & \multirow[t]{3}{*}{ Central Lowland } & \multirow[t]{3}{*}{ Eastern Lake } & Forest & 39.4 & 29.8 \\
\hline & & & Agriculture & 31.9 & 28.9 \\
\hline & & & Urban & 18.0 & 29.1 \\
\hline \multirow[t]{3}{*}{ Devonian-Silurian carbonate } & \multirow[t]{3}{*}{ Ridge and Valley } & \multirow[t]{3}{*}{ Appalachian Mountain } & Forest & 43.0 & 43.2 \\
\hline & & & Agriculture & 49.6 & 41.2 \\
\hline & & & Urban & 5.0 & 6.2 \\
\hline \multirow[t]{3}{*}{ Appalachian Mountain carbonate } & \multirow[t]{3}{*}{ Ridge and Valley } & \multirow[t]{3}{*}{ Appalachian Mountain } & Forest & 27.4 & 30.4 \\
\hline & & & Agriculture & 66.0 & 54.0 \\
\hline & & & Urban & 2.3 & 4.3 \\
\hline \multirow[t]{3}{*}{ Northeastern Glaciated surficial } & \multirow[t]{2}{*}{ Appalachian Plateaus } & Glaciated Low Plateau & Forest & 33.9 & 27.9 \\
\hline & & Glaciated High Plateau & Agriculture & 36.9 & 30.8 \\
\hline & Ridge and Valley & Appalachian Mountain & Urban & 16.9 & 16.3 \\
\hline \multirow[t]{3}{*}{ Great Valley siliciclastic } & \multirow[t]{3}{*}{ Ridge and Valley } & \multirow[t]{3}{*}{ Great Valley } & Forest & 31.4 & 28.3 \\
\hline & & & Agriculture & 61.0 & 52.9 \\
\hline & & & Urban & 4.8 & 7.7 \\
\hline \multirow[t]{3}{*}{ Great Valley carbonate } & \multirow[t]{3}{*}{ Ridge and Valley } & \multirow[t]{3}{*}{ Great Valley } & Forest & 14.1 & 9.6 \\
\hline & & & Agriculture & 67.8 & 57.8 \\
\hline & & & Urban & 14.9 & 20.0 \\
\hline \multirow[t]{3}{*}{ Blue Ridge crystalline } & \multirow[t]{3}{*}{ Blue Ridge } & \multirow[t]{3}{*}{ South Mountain } & Forest & 85.6 & 82.9 \\
\hline & & & Agriculture & 12.1 & 10.1 \\
\hline & & & Urban & .5 & 1.1 \\
\hline \multirow[t]{3}{*}{ Triassic Lowland siliciclastic } & \multirow[t]{3}{*}{ Piedmont } & \multirow{3}{*}{$\begin{array}{l}\text { Gettysburg-Newark } \\
\text { Lowland }\end{array}$} & Forest & 41.7 & 31.6 \\
\hline & & & Agriculture & 46.1 & 46.6 \\
\hline & & & Urban & 8.6 & 9.8 \\
\hline \multirow[t]{3}{*}{ Piedmont carbonate } & \multirow[t]{3}{*}{ Piedmont } & \multirow[t]{3}{*}{ Piedmont Lowland } & Forest & 11.2 & 5.3 \\
\hline & & & Agriculture & 70.1 & 62.9 \\
\hline & & & Urban & 14.9 & 17.1 \\
\hline
\end{tabular}

\footnotetext{
${ }^{1}$ Physiographic province and physiographic section from Lindsey and Bickford, (1999).
}

${ }^{2}$ Forest dominant land cover is the combination of deciduous, evergreen, and mixed forest. Agriculture dominant land cover is the combination of row crop and hay/pasture land covers. Urban dominant land cover is the combination of low-intensity residential, high-intensity residential, and commercial/industrial/ transportation in the 1992 NLCD and low-intensity developed, medium-intensity developed, and high-intensity developed in the 2001 NLCD.

${ }^{3}$ Multi-Resolution Land Characteristics (1992).

${ }^{4}$ Multi-Resolution Land Characteristics (2001). 
Table 2. Six U.S. Geological Survey investigations of major-use pesticides in ground water of Pennsylvania, 1997-2002, where data quality assurance could be documented.

[Investigations of major-use pesticides in ground water of Pennsylvania conducted 1990-98 are summarized in Lindsey and Bickford (1999); NAWQA, National Water-Quality Assessment; USGS, U.S. Geological Survey; NWQL, USGS National Water Quality Laboratory; PADEPL, Pennsylvania Department of Environmental Protection Laboratory; PDA, Pennsylvania Department of Agriculture; OGRL, USGS Organic Geochemistry Research Laboratory; GCMS, gas chromatography/mass spectrometry; HPLCMS, High Performance Liquid Chromatography/Mass Spectrometry]

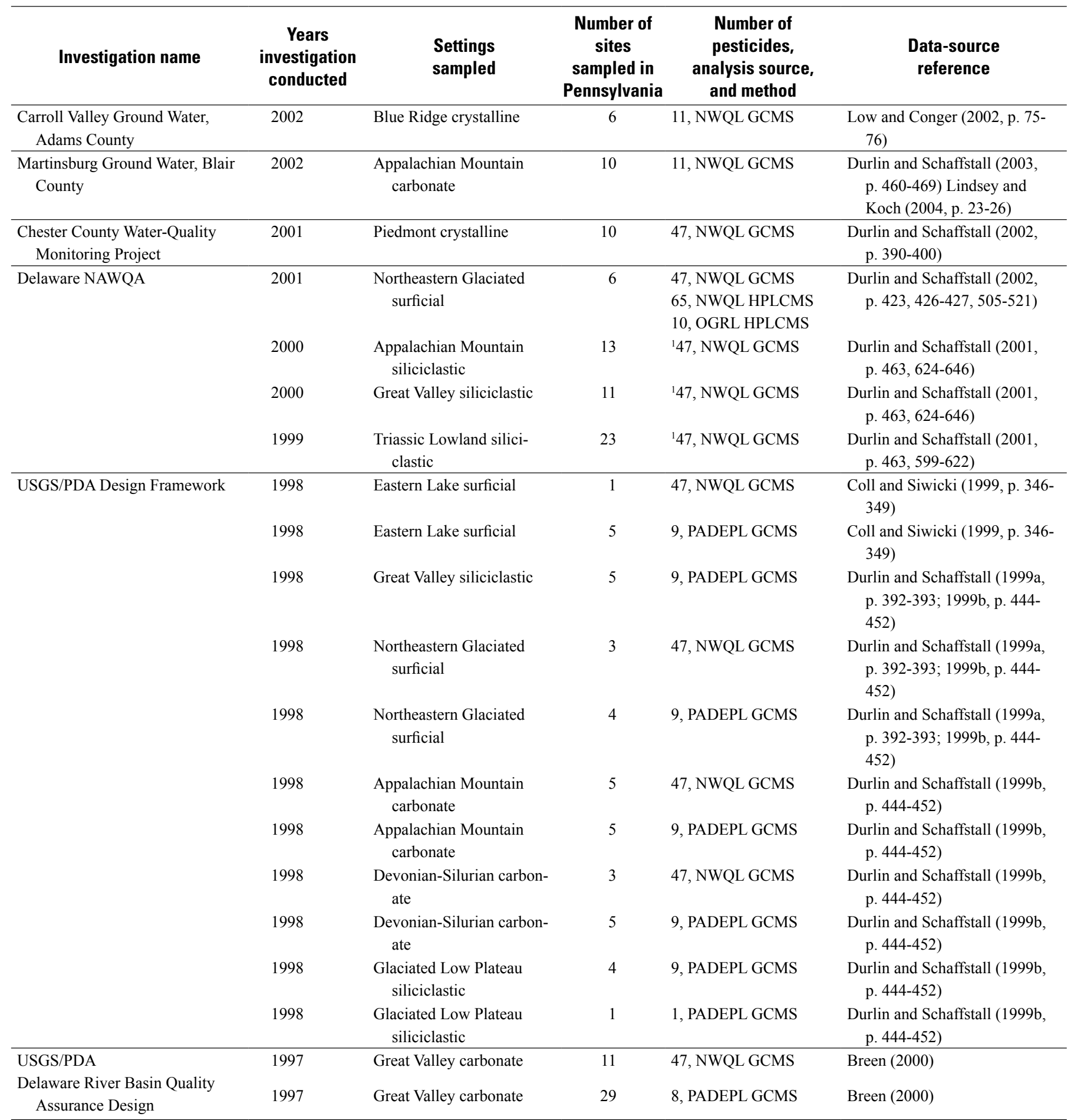

\footnotetext{
${ }^{1}$ Data for 65 additional pesticides are available in the USGS National Water Information System for these wells.
} 


\section{Methods}

Ground-water studies were conducted in baseline-assessment areas, for trends assessment or occurrence monitoring, and in areas of special ground-water protection. A description of methods for these studies follows.

\section{Baseline-Assessment Areas}

To understand trends in concentrations of pesticides, wells in vulnerable settings that were part of assessments of pesticide occurrence from 1993 to 2001 and had waters with one or more pesticides were resampled in 2003 and 2004. Previous PDA and USGS pesticide data were reviewed to evaluate candidates for repeat sampling. Site reconnaissance was conducted to confirm site status and obtain written permission from the landowner to sample. The frequency of sampling was set at one time per year. Water samples were collected from 4 wells in each of the Great Valley carbonate, Appalachian Mountain carbonate, Piedmont carbonate, and Triassic Lowland siliciclastic settings in 2003, and 14 of those 16 wells were resampled in 2004 ( 2 new wells had to be located for the 2004 sample collection). Pesticide samples collected in April 2003 for trends assessments were analyzed at the USGS NWQL, and those collected in March-April 2004 were analyzed at the PADEPL.

For the baseline-assessment component, a 5-year plan for monitoring was developed to obtain data for settings with little or no data using documented vulnerability rankings for hydrogeologic settings found in Lindsey and Bickford (1999) and the most recent data from well-water sampling completed by PDA and other agencies (table 2). The plan called for sampling one setting per year. The Blue Ridge crystalline and Triassic Lowland siliciclastic setting was sampled in 2003, the Eastern Lake surficial setting was sampled in 2004, the Devonian-Silurian carbonate setting was sampled in 2005, the Great Valley siliciclastic setting was sampled in 2006, and the Northeastern Glaciated surficial setting was sampled in 2007. Each setting was subdivided using a 20- or 30-cell equal area grid of the assessment area, and a random point was assigned for starting the process of well selection in each grid cell (Scott, 1990). For the Blue Ridge crystalline and Triassic Lowland siliciclastic setting, a 20-cell grid was based on a land-use coverage subset for orchards. In the Eastern Lake surficial setting, a 20-cell grid was based on agricultural land use (vineyards primarily); the large urban area occupied by the city of Erie was excluded. For the Great Valley siliciclastic and Devonian-Silurian carbonate settings, a 30-cell grid was based on agricultural land use comprised of hay/pasture and row crops classifications. For the Northeastern Glaciated surficial setting, the boundary of the setting from Lindsey and Bickford (1999) was expanded to include additional glacial deposits shown in Williams and others (1998); a 30-well grid was based on hay/pasture and row crops agricultural land use. The five baseline-assessment areas and year of sample collection are noted on figure 1. More detailed discussions of the study areas sampled are found in the "Pesticides in Ground Water for the Baseline Assessment of Hydrogeologic Settings, 2003-07" section of this report.

Pennsylvania Topographic and Geologic Survey (PATGS) online well-record data, scanned well records available from PATGS on compact disc (CD), and well records from drilling companies were used to verify well depth and lithology. Site reconnaissance established that wells were generally within $75 \mathrm{ft}$ of targeted land use. After permission to sample the well was obtained from the homeowner, plumbing was inspected to establish a raw-water sampling point. A Global Positioning System (GPS) unit was used to establish a latitude and longitude for the well, and well-construction data were entered into the USGS Ground-Water Site Inventory (GWSI) database. The records of wells sampled are given in table 3 (back of report).

Sampling of wells for occurrence monitoring was planned for May through August to reflect conditions when the majority of pesticides were applied. Wells were sampled once. In most settings, the number of wells sampled equaled the number of grid cells; in the Devonian-Silurian carbonate and Northeastern Glaciated surficial settings, only 28 wells were sampled because of difficulties in finding wells meeting the well-selection criteria (discussed in Quality Assurance section). Pesticides samples were analyzed predominantly at the USGS NWQL. The PADEPL analyzed water from 10 wells sampled in the Blue Ridge crystalline and Triassic Lowland siliciclastic setting in August 2003 and from 20 wells sampled in the Eastern Lake surficial setting May-August 2004. Minimum reporting levels (MRLs) for pesticides analyzed at the PADEPL were greater than those reported at the USGS NWQL, and fewer pesticides per sample were analyzed by the PADEPL.

\section{Areas of Special Ground-Water Protection}

Areas of special ground-water protection are designated by the PDA where concentrations of pesticides in ground water are at or above action levels specified in the PPGWS (appendix 4). Detailed investigations of pesticide occurrence, seasonal change in concentrations related to changing water levels, and persistence in areas of special ground-water protection were done in Berks, Blair, and Lancaster Counties. Monitoring was done at and around three wells, referred to as hot-spot wells (BA 437, LN 1842, and BE 1370 are the USGS local well numbers for PDA-designated hot-spot wells, fig. 7). To evaluate concentration change related to changes in water levels and overall persistence of compounds, these three wells were sampled quarterly during 2003-06 and three times in 2007. Quarterly sampling was planned with one sample for each of the following criteria: 1) summer-declining water levels in wells (mid-growing season after application of herbicides), 2) fall - stable water levels after summer decline (harvest season), 3) winter-rising water levels in wells resulting from seasonal recharge, and 4) spring_rising water levels 


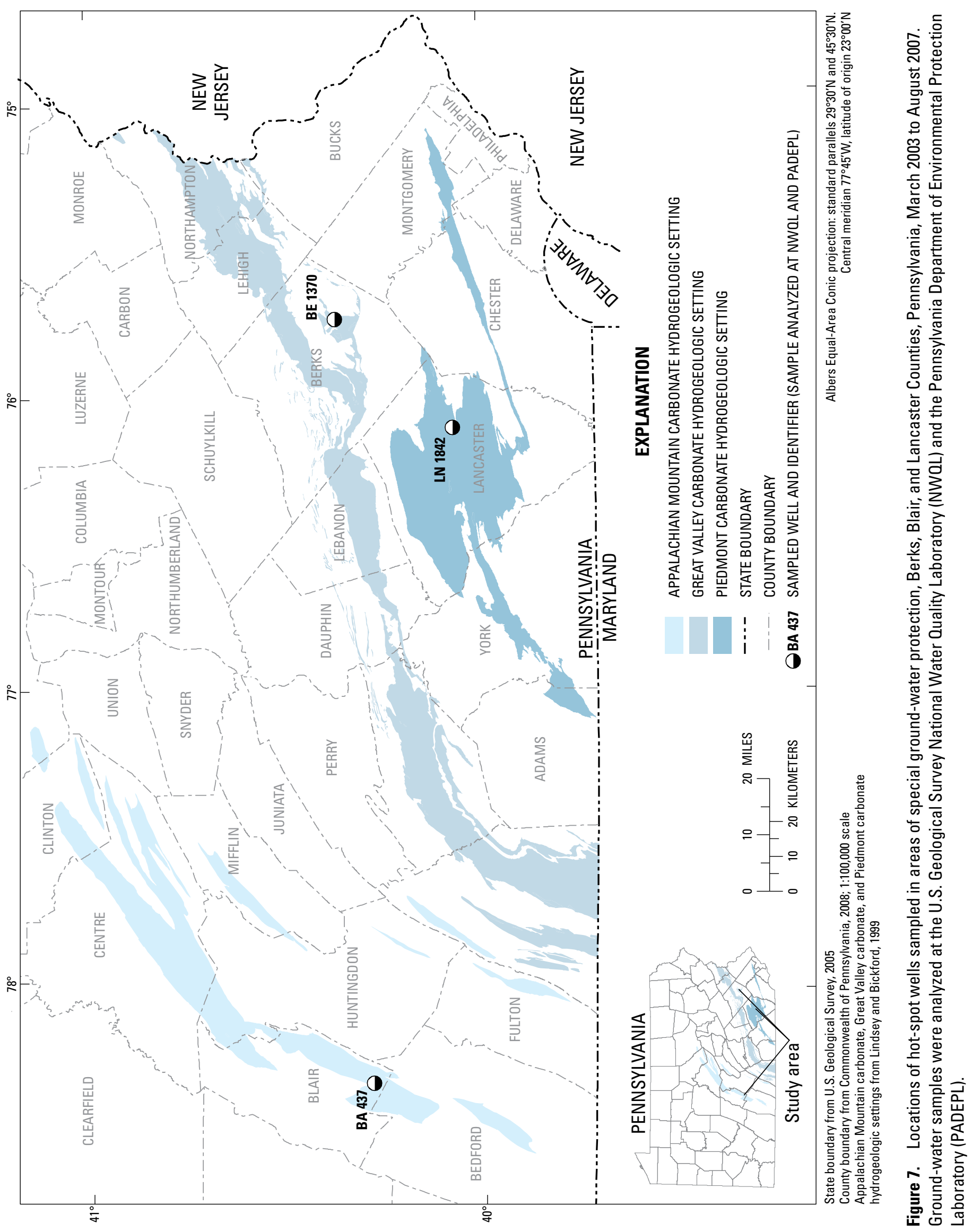


resulting from spring or early summer storms. Water levels were estimated by use of the nearest USGS observation well. Sampling during a stable water-level period was the most problematic because of differences in water levels between settings and the quick change in water levels resulting from large storms.

To better understand persistence and possible degradation of parent compounds, a characterization of pesticide-degradation products in water from hot-spot wells BA 437, LN 1842, BE 1370 and neighboring water supplies was conducted. In 2005, hot-spot well BA 437 plus five neighboring wells and hot-spot well BE 1370 plus a spring and five neighboring wells were characterized. In 2006, hot-spot well LN 1842 plus five neighboring wells were characterized.

At hot-spot well BA 437 only, depth and yield characteristics of water-bearing zones and the depth that water with elevated pesticide concentrations entered the well were determined. A borehole video camera and a suite of borehole geophysical logs (caliper, gamma, temperature, and resistivity) were used to identify the zones where water entered the bore-

hole. Heatpulse flowmetering was used to evaluate the rate and direction of vertical flow of ground water in the borehole to determine the depth that the water entered the well. An inflatable packer was used to isolate discrete water-bearing zones, and a submersible sampling pump was used to collect water samples in the shallow and deep water-bearing zones.

\section{Evaluation of Water-Quality Conditions}

Methods used for physical and chemical water-quality sampling, processing, and laboratory analyses are also described. Field-data collection, laboratory analyses, and statistical analyses were consistent with approved and published methods.

\section{Physical Characteristics}

Specific conductance, $\mathrm{pH}$, dissolved oxygen, turbidity, and water temperature were measured with calibrated field meters or calibrated multi-parameter water-quality meters (table 4). Calibration followed procedures documented by Wilde (variously dated). Barometric pressure was recorded at most sites using a Thommen field barometer.

\section{Chemical Sampling and Processing}

Well-water sampling equipment was cleaned thoroughly prior to sample collection, following the USGS protocols for organic- and inorganic-compound sampling (Wilde, 2004). Collection of most well-water samples followed protocols documented by Wilde and others (1999) with several modifications: 1) brass fittings were used instead of Teflon to connect to plumbing at sampling points, 2) a flow manifold or processing chamber was not used, 3) Millipore filter holders with 0.45 -micron filters were used instead of capsule filters for the filtration of nitrate/nitrite samples (years 2004 to 2007), and 4) pesticide samples were filtered if turbidity readings at the end of the well purge were greater than 4 Nephelometric Turbidity Units (NTU). Water with turbidity of 5 NTU or less does not have to be filtered for public supply (U.S. Environmental Protection Agency, 2008). This study did not include a comparison of results for filtered and non-filtered samples. Generally, there are no differences in results between filtered samples and unfiltered samples with low turbidity unless sufficient dissolved organic carbon is present; some dissolved organic carbon can pass through the filter in a filtered sample (Duane Wydoski, U.S. Geological Survey, oral commun., 2008). For the samples collected in the vicinity of hot-spot wells, 0.45 -micron capsule filters were used for the filtration of nitrate samples, and all pesticide samples were filtered.

At most wells sampled, existing submersible pumps provided sample water to a tap either at the base of the pressure tank or at an outside faucet that by-passed any treatment. On several occasions, collections points were either at accessible locations on irrigation systems or public-water-supply lines. As the well was purged, measurements of $\mathrm{pH}$, specific conductance, dissolved oxygen, water temperature, turbidity, and water level were recorded. When readings became stable (Wilde, variously dated), the well-water samples were collected.

Well-water samples were collected after volumetric purge criteria for each well were met. For processing of pesticide samples, if the turbidity readings were less than or equal to 4 NTU, water was collected directly into two 1-L amber glass bottles that were commercially cleaned and baked at $450^{\circ} \mathrm{C}$ to burn off all residual organic compounds. If turbidity readings were greater than 4 NTU, a pre-cleaned Savillex Teflon inline filter holder with a baked, glass microfiber filter (47-mm diameter, 0.7-micron pore size) was used to filter the sample from the tap into two 1-L amber glass bottles. One bottle was shipped to the laboratory; the second bottle was held as an archive sample. For processing of well-water samples for total coliform and E. coli bacteria, water was collected directly into a pre-sterilized $125-\mathrm{mL}$ bottle (sodium thiosulfate added to all bottles at the PADEPL as a chlorine neutralizer prior to sample collection). For nitrate/nitrite sample processing, well water was initially collected in a pre-cleaned bottle, then filtered to remove particles larger than $0.45 \mu \mathrm{g} / \mathrm{L}$ using a cleaned $50-\mathrm{mL}$ syringe and either a pre-conditioned ground-water capsule filter or a Millipore filter unit with a 47-mm diameter mixed-cellulose-ester filter into a pre-rinsed $125-\mathrm{mL}$ bottle. All bottles were immediately placed on ice and returned to the Pennsylvania Water Science Center (PA WSC) laboratory where they were either maintained at $4^{\circ} \mathrm{C}$ or shipped to the USGS NWQL or the PADEPL. The nitrate, nitrite, and bacteria samples were shipped the day of collection; pesticide samples were shipped within 2 days of sample collection via overnight delivery to the analytical laboratories. 
Table 4. Physical characteristics, units, accuracies, and equipment types used for this study.

[NWIS, National Water Information System; ${ }^{\circ} \mathrm{C}$, degrees Celsius; YSI, Yellow Springs Instrument Company; ICM, Industrial Chemical Measurement; $\mu \mathrm{S} / \mathrm{cm}$, microsiemens per centimeter at $25^{\circ} \mathrm{C} ; \mathrm{mm}$, millimeters; $\mathrm{mg} / \mathrm{L}$, milligrams per liter; NTU, Nephelometric Turbidity Units]

\begin{tabular}{|c|c|c|c|c|}
\hline Measurements & NWIS code & $\begin{array}{l}\text { Reporting } \\
\text { units }\end{array}$ & $\begin{array}{l}\text { Reporting } \\
\text { accuracy }\end{array}$ & $\begin{array}{l}\text { Equipment/ } \\
\text { sensor type }\end{array}$ \\
\hline \multirow[t]{2}{*}{ Water temperature } & 00010 & ${ }^{\circ} \mathrm{C}$ & $\pm 0.15^{\circ} \mathrm{C}$ & YSI 556, precision thermister \\
\hline & 00010 & ${ }^{\circ} \mathrm{C}$ & $\pm 0.3{ }^{\circ} \mathrm{C}$ & $\begin{array}{l}\text { YSI } 58 \text { dissolved oxygen meter } \\
\text { thermister }\end{array}$ \\
\hline $\mathrm{pH}$ & 00400 & standard units & $\pm 0.01 \mathrm{pH}$ & $\begin{array}{l}\text { Ross combination electrode, Beck- } \\
\text { man } 210 \mathrm{pH} \text { meter }\end{array}$ \\
\hline Specific conductivity & 00095 & $\mu \mathrm{S} / \mathrm{cm}$ at $25^{\circ} \mathrm{C}$ & $\begin{array}{l} \pm 0.5 \text { percent of the reading or } \\
\pm 1 \mu \mathrm{S} / \mathrm{cm} \text {; whichever is greater }\end{array}$ & $\begin{array}{l}\text { YSI } 556, \\
\text { 4-electrode cell with auto- } \\
\text { ranging }\end{array}$ \\
\hline Dissolved oxygen & 00300 & $\mathrm{mg} / \mathrm{L}$ & $\pm 0.3 \mathrm{mg} / \mathrm{L}$ & YSI 58, polarographic \\
\hline Barometric pressure & 00025 & mm mercury & \pm 0.75 to $1.5 \mathrm{~mm}$ mercury & $\begin{array}{l}\text { Thommen Classic Altimeter Plus } \\
\text { Barometer }\end{array}$ \\
\hline \multirow[t]{2}{*}{ Turbidity } & 63676 & NTU & $\begin{array}{l} \pm 2 \text { percent plus stray light (from } \\
\text { debris on mirror, ampule, etc.) }\end{array}$ & $\begin{array}{l}\text { Hach } 2100 \mathrm{P}, 400-680 \mathrm{~nm} \text { light } \\
\text { source, } 90 \text { degree detection } \\
\text { angle, multiple detectors with } \\
\text { ratio compensation }\end{array}$ \\
\hline & 63675 & NTU & $\begin{array}{l}0.1 \text { percent or } \\
\pm 1 \text { count }\end{array}$ & $\begin{array}{l}\text { ICM turbidity meter, Sensor Mode } \\
11520,400-680 \mathrm{~nm} \text { light source, } \\
90 \text { degree detection angle, one } \\
\text { detector }\end{array}$ \\
\hline
\end{tabular}

\section{Laboratory Analyses}

Four laboratories were used for analytical work done during the project: the USGS Ohio Water Microbiology Laboratory (OWML), the USGS NWQL, the USGS Organic Geochemistry Research Laboratory (OGRL), and the PADEPL. Timeframes when samples were submitted to respective laboratories are found in table 5.

Bacteria were analyzed at the USGS OWML and the PADEPL. Both laboratories used Standard Method 9223B (Chromogenic Substrate Test) (American Public Health Association, American Water Works Association, and Water Pollution Control Federation, 2004), Idexx Colilert Quanti-Tray equipment, which gives results in Most Probable Number per $100 \mathrm{~mL}$ (MPN/100 mL) of total coliform and E. coli bacteria.

Nitrate and nitrite were analyzed at the PADEPL using the USEPA 353.2 method that uses cadmium reduction of nitrate to nitrite followed by colorimetry (on file at the
PADEPL quality-assurance office [James Yoder, Pennsylvania Department of Environmental Protection Laboratory, Quality Assurance Section Chief, oral commun., February 4, 2008]).

At the NWQL, the concentration of nitrate plus nitrite nitrogen was determined using a method comparable to USEPA 353.2 (cadmium reduction of nitrate to nitrite followed by colorimetry), and nitrite concentration was determined using colorimetry (Fishman, 1993).

For pesticides analyzed at the PADEPL (table 6), a modification of USEPA Method 525.2 (Eichelberger and others, 1994) was used. Method 525.2 uses gas chromatography/mass spectroscopy (GCMS) with initial solid-phase extraction. The modification involved the extraction solvent; PADEPL used a 1:1 methylene chloride-acetone mix as the extraction solvent rather than a 1:1 methylene chloride-ethyl acetate mix because better extraction results have been obtained from the modified solvent mix (Michael Webb, Pennsylvania Department of Environmental Protection Laboratory, written commun., 
Table 5. Laboratories used for analytical work by analysis type and date of sample collection.

[USGS OWML, U.S. Geological Survey Ohio Water Microbiology Laboratory; USGS NWQL, U.S. Geological Survey National Water Quality Laboratory in Denver, Colo.; PADEPL, Pennsylvania Department of Environmental Protection Laboratory in Harrisburg, Pa.; USGS OGRL, U.S. Geological Survey Organic Geochemistry Research Laboratory in Lawrence, Kans.; E. coli, Escherichia coli; -, not applicable]

\begin{tabular}{|c|c|c|c|}
\hline \multirow{2}{*}{ Laboratories } & Pesticides & $\begin{array}{l}\text { Nitrate plus nitrite and nitrite or } \\
\text { nitrate and nitrite }{ }^{1}\end{array}$ & $\begin{array}{l}\text { Total coliform } \\
\text { and E. coli }\end{array}$ \\
\hline & \multicolumn{3}{|c|}{ Month and year of sample collection } \\
\hline USGS OWML & - & - & March-May 2003 \\
\hline USGS NWQL & $\begin{array}{c}\text { March-May } 2003 \\
\text { May, June, Aug., Sept. } 2005 \\
\text { Jan., May-Sept. 2006, } \\
\text { June-Sept. } 2007\end{array}$ & March-May 2003 & - \\
\hline PADEPL & $\begin{array}{c}\text { Aug.-Oct., Dec. 2003, } \\
\text { May-Aug., Oct., Dec. } 2004\end{array}$ & $\begin{array}{l}\text { Aug.-Oct. } \\
\text { May-Aug., } \\
\text { May, June, A } \\
\text { Jan., May- } \\
\text { June-S }\end{array}$ & $\begin{array}{l}03 \\
2004 \\
2005 \\
06\end{array}$ \\
\hline USGS OGRL & $\begin{array}{l}\text { Aug., Sept. 2005, } \\
\text { June } 2006\end{array}$ & & \\
\hline
\end{tabular}

${ }^{1}$ The PADEPL reported concentrations of nitrate as nitrogen and nitrite as nitrogen; the USGS NWQL reported concentrations of nitrate plus nitrite as nitrogen and nitrite as nitrogen.

2002). Several compounds analyzed (pendimethalin and acetochlor, for example) are not listed in this method; however, the PADEPL has run Minimum Detection Level and Demonstration of Capability studies for these compounds in water and has documented the results (available at PADEPL—Martina McGarvey, Pennsylvania Department of Environmental Protection Laboratory, oral commun., 2008).

Carbaryl, methomyl, and oxamyl were determined by USEPA Method 531.1 at the PADEPL (Munch, 1995); this method involves direct aqueous injection into a reverse phase high-performance liquid chromatography (HPLC) column with post-column derivatization and fluorescence detection.

Pesticides were analyzed at the NWQL using C-18 solidphase extraction and capillary-column GCMS with selectedion monitoring (table 7) (Zaugg and others, 1995; Madsen and others, 2003) (March to May 2003 and May 2005 to September 2007) or graphitized carbon-based solid-phase extraction and high-performance liquid chromatography/mass spectrometry (HPLCMS) (table 8) (Furlong and others, 2001) (May 2003). Pesticide samples collected in May 2003 were analyzed at the NWQL using two methods to measure concentrations of compounds of interest to PDA that could not be obtained through one method. Analytical methodology used at the USGS OGRL involved solid-phase extraction and HPLCMS (Lee and others, 2002; Lee and Strahan, 2003) (table 9). Ten compounds have not been formally approved for inclusion in the method (Michael Meyer, U.S. Geological Survey Organic Geochemistry Research Laboratory, oral commun., 2008) (table 9). 
Table 6. Pesticides analyzed at the Pennsylvania Department of Environmental Protection Laboratory (PADEPL) in Harrisburg, Pennsylvania, from August 2003 to December 2004.

[NWIS, National Water Information System; USEPA, U.S. Environmental Protection Agency; MDL, method detection limit; MRL, minimum reporting level; $\mu \mathrm{g} / \mathrm{L}$, micrograms per liter; RPA, Rhone Poulenc Agro; NA, not available; NC, no code; FY04, fiscal year 2004]

\begin{tabular}{|c|c|c|c|c|c|c|c|}
\hline \multicolumn{4}{|c|}{$\begin{array}{l}\text { Pesticides analyzed in samples collected for the baseline-assessment of the } \\
\text { Blue Ridge crystalline and Triassic Lowland siliciclastic ( } 10 \text { of } 20 \text { samples) } \\
\text { (2003) and the Eastern Lake surficial (20 samples) (2004) } \\
\text { hydrogeologic settings }\end{array}$} & \multicolumn{4}{|c|}{$\begin{array}{l}\text { Pesticides analyzed in samples collected for the baseline-trends } \\
\text { assessments (Great Valley carbonate, Piedmont carbonate, Appalachian } \\
\text { Mountain carbonate, and Triassic Lowland siliciclastic) (2004) and trends } \\
\text { assessments in areas of special ground-water protection (2004) }\end{array}$} \\
\hline Analyte & $\begin{array}{l}\text { NWIS } \\
\text { parameter } \\
\text { code }\end{array}$ & $\begin{array}{l}\text { Minimum } \\
\text { reporting } \\
\text { level, } \\
\text { in } \\
\text { micrograms } \\
\text { per liter }\end{array}$ & $\begin{array}{l}\text { Method } \\
\text { detection } \\
\text { limit, } \\
\text { in } \\
\text { micrograms } \\
\text { per liter }\end{array}$ & Analyte & $\begin{array}{l}\text { NWIS } \\
\text { parameter } \\
\text { code }\end{array}$ & $\begin{array}{l}\text { Minimum } \\
\text { reporting } \\
\text { level, } \\
\text { in } \\
\text { micrograms } \\
\text { per liter }\end{array}$ & $\begin{array}{l}\text { Method } \\
\text { detection } \\
\text { limit, } \\
\text { in } \\
\text { micrograms } \\
\text { per liter }\end{array}$ \\
\hline USEPA 525.2 Method: & & & & USEPA 525.2 Method: & & & \\
\hline Acetochlor & 49260 & $0.10-0.25$ & 0.10 & Acetochlor & 49260 & $0.10-0.25$ & 0.10 \\
\hline Alachlor & 46342 & $0.10-0.25$ & .08 & Alachlor & 46342 & $0.10-0.25$ & .08 \\
\hline Atrazine & 39632 & $0.10-0.25$ & .07 & Atrazine & 39632 & $0.10-0.25$ & .07 \\
\hline Azinphos-methyl ${ }^{1}$ & 82686 & 1.0 & N/A & Chlorothalonil & 49306 & $0.10-0.25$ & .08 \\
\hline Captan & 61582 & $0.10-1.0$ & .10 & Chlorpyriphos (Dursban) & 38933 & $0.10-0.25$ & .09 \\
\hline Chlorothalonil & 49306 & $0.10-0.25$ & .08 & Dichlobenil $^{5}$ & 63009 & 0.10 & .06 \\
\hline Chlorpyriphos (Dursban) & 38933 & $0.10-0.25$ & .09 & Fenpropathrin ${ }^{5}$ & 64044 & 0.10 & .08 \\
\hline Dichlobenil $^{2}$ & 63009 & 0.10 & .06 & Hexachlorocyclopentadiene & 34386 & $0.10-0.25$ & .09 \\
\hline Diuron $^{3}$ & 49300 & NA & NA & Metolachlor & 39415 & $0.10-0.25$ & .10 \\
\hline Fenpropathrin $^{2}$ & 64044 & 0.10 & .08 & Metribuzin & 82630 & $0.10-0.25$ & .07 \\
\hline Hexachlorocyclopentadiene & 34386 & $0.10-0.25$ & .09 & Pendimethalin & 82683 & $0.10-0.25$ & .06 \\
\hline Metolachlor & 39415 & $0.10-0.25$ & .10 & Phosmet $^{5}$ & 61601 & 1.00 & .09 \\
\hline Metribuzin & 82630 & $0.10-0.25$ & .07 & Simazine & 04035 & $0.10-0.25$ & .10 \\
\hline Parathion-methyl & 82667 & 0.10 & .05 & & & & \\
\hline Pendimethalin & 82683 & $0.10-0.25$ & .06 & & & & \\
\hline Phosmet $^{2}$ & 61601 & 1.00 & .09 & & & & \\
\hline Phosphamidon $^{4}$ & 63736 & 1.0 & N/A & & & & \\
\hline Simazine & 04035 & $0.10-0.25$ & .10 & & & & \\
\hline Terbacil & 82665 & $0.10-0.25$ & .10 & & & & \\
\hline Trifluralin $^{2}$ & 82661 & 0.10 & .07 & & & & \\
\hline $\begin{array}{l}\text { 1,3-dimethyl-2-nitrobenzene } \\
\text { (surrogate) }\end{array}$ & $\mathrm{NC}$ & 0.10 & NA & $\begin{array}{l}\text { 1, 3-dimethyl-2-nitrobenzene } \\
\text { (surrogate) }\end{array}$ & $\mathrm{NC}$ & 0.10 & NA \\
\hline Pyrene-d10 (surrogate) & $\mathrm{NC}$ & 0.10 & NA & Pyrene-d10 (surrogate) & $\mathrm{NC}$ & 0.10 & NA \\
\hline Triphenylphosphate (surrogate) & $\mathrm{NC}$ & 0.10 & NA & Triphenylphosphate (surrogate) & $\mathrm{NC}$ & 0.10 & NA \\
\hline Perylene-d12 (surrogate) & $\mathrm{NC}$ & 0.10 & NA & Perylene-d 12 (surrogate) & $\mathrm{NC}$ & 0.10 & NA \\
\hline \multicolumn{4}{|l|}{ USEPA 531.1 Method: } & \multicolumn{4}{|c|}{ (October and December 2004 samples only at Hot-Spot Trend sites: ) } \\
\hline Carbaryl & 82680 & $1.6-5.0$ & $0.338-2.602$ & Isoxaflutole (RPA 201772) & 62733 & 1.25 & NA \\
\hline \multirow{10}{*}{$\begin{array}{l}\text { Methomyl } \\
\text { Oxamyl }\end{array}$} & 49296 & $1.6-5.0$ & $0.332-1.723$ & \multirow{3}{*}{$\begin{array}{l}\text { (RPA 203328) (terminal } \\
\text { metabolite of isoxaflutole) } \\
\text { [2-methanesulphonyl-4- } \\
\text { trifluromethylbenzoic acid] }\end{array}$} & \multirow[t]{3}{*}{62656} & \multirow[t]{3}{*}{1.25} & \multirow[t]{3}{*}{ NA } \\
\hline & 38866 & $1.6-5.0$ & $0.504-2.689$ & & & & \\
\hline & & & & & & & \\
\hline & & & & (RPA 202248) (primary & \multirow[t]{7}{*}{63011} & \multirow[t]{7}{*}{1.25} & \multirow[t]{7}{*}{ NA } \\
\hline & & & & metabolite of isoxaflutole) & & & \\
\hline & & & & [2-cyclopropylcarbonyl-3- & & & \\
\hline & & & & (2-methylsulphonyl-4- & & & \\
\hline & & & & trifluoromethylpenyl)-3- & & & \\
\hline & & & & oxopropanenitrile; & & & \\
\hline & & & & diketonitrile] & & & \\
\hline
\end{tabular}

\footnotetext{
${ }^{1}$ MRLs during project were reported as $0.10-0.50 \mu \mathrm{g} / \mathrm{L}$. A PADEPL data review conducted in 2007 changed this level to $1.0 \mu \mathrm{g} / \mathrm{L}$.

${ }^{2}$ FY04 addition.

${ }^{3} \mathrm{MRL}$ during project was reported as $0.10 \mu \mathrm{g} / \mathrm{L}$. A PADEPL data review conducted in 2007 could not verify acceptable recoveries and mass spectra during the period of sample submittal; therefore, acceptable MDLs and MRLs are not possible.
}

${ }^{4} \mathrm{MRLs}$ during project were reported as $0.10-0.25 \mu \mathrm{g} / \mathrm{L}$. A PADEPL data review conducted in 2007 changed this level to $1.0 \mu \mathrm{g} / \mathrm{L}$.

${ }^{5}$ FY04 addition (July 2004) at the three hot-spot wells in the areas of special ground-water protection. 
Table 7. Pesticides analyzed using C-18 solid-phase extraction and capillary-column gas chromatography/mass spectrometry with selected-ion monitoring at the U.S. Geological Survey National Water Quality Laboratory in Denver, Colorado, from March to May 2003 and May 2005 to September 2007.

[NWIS, National Water Information System; bolding of compound names denotes all values are estimated because of low recoveries or high variability in lab reagent spikes; pct, percent; NA, not available]

\begin{tabular}{|c|c|c|c|c|c|c|c|}
\hline Compound & $\begin{array}{c}\text { NWIS } \\
\text { parameter } \\
\text { code }\end{array}$ & $\begin{array}{l}\text { Minimum } \\
\text { reporting } \\
\text { level, } \\
\text { in } \\
\text { micrograms } \\
\text { per liter }\end{array}$ & $\begin{array}{l}\text { Method } \\
\text { detection } \\
\text { limit, } \\
\text { in } \\
\text { micrograms } \\
\text { per liter }\end{array}$ & Compound & $\begin{array}{c}\text { NWIS } \\
\text { parameter } \\
\text { code }\end{array}$ & $\begin{array}{l}\text { Minimum } \\
\text { reporting } \\
\text { level, } \\
\text { in } \\
\text { micrograms } \\
\text { per liter }\end{array}$ & $\begin{array}{l}\text { Method } \\
\text { detection } \\
\text { limit, } \\
\text { in } \\
\text { micrograms } \\
\text { per liter }\end{array}$ \\
\hline 2,6-Diethylaniline & 82660 & $0.002-0.006$ & $0.001-0.003$ & Metolachlor & 39415 & $0.006-0.013$ & $0.003-0.006$ \\
\hline Acetochlor & 49260 & 0.006 & 0.003 & Napropamide & 82684 & $0.007-0.018$ & $0.003-0.009$ \\
\hline Alachlor & 46342 & $0.005-0.006$ & $0.002-0.003$ & Parathion & 39542 & 0.010 & 0.005 \\
\hline Atrazine & 39632 & 0.007 & 0.004 & Parathion-methyl & 82667 & $0.008-0.015$ & $0.004-0.008$ \\
\hline Deethylatrazine (CIAT) ${ }^{2}$ & 04040 & $0.006-0.014$ & $0.003-0.007$ & Pebulate & 82669 & $0.004-0.0041$ & $0.002-0.0021$ \\
\hline Carbaryl & 82680 & $0.06-0.041$ & $0.021-0.03$ & Prometon & 04037 & $0.005-0.015$ & $0.002-0.007$ \\
\hline Carbofuran & 82674 & $0.020-0.02$ & $0.010-0.01$ & Propachlor & 04024 & $0.010-0.025$ & $0.0048-0.012$ \\
\hline Chlorpyrifos & 38933 & 0.005 & 0.003 & Propanil & 82679 & 0.011 & 0.005 \\
\hline cis-Permethrin & 82687 & $0.006-0.01$ & $0.003-0.005$ & Propargite & 82685 & $0.02-0.023$ & $0.01-0.011$ \\
\hline Cyanazine & 04041 & 0.018 & 0.009 & Propyzamide & 82676 & $0.004-0.0041$ & $0.002-0.0021$ \\
\hline Dacthal (DCPA) ${ }^{3}$ & 82682 & $0.0030-0.003$ & $0.0015-0.002$ & Simazine & 04035 & $0.005-0.006$ & $0.002-0.003$ \\
\hline Desulfinylfipronil & 62170 & $0.004-0.012$ & 0.006 & Tebuthiuron & 82670 & 0.016 & 0.008 \\
\hline Desulfinylfipronil amide & 62169 & $0.009-0.029$ & 0.015 & Terbacil & 82665 & $0.034-0.04$ & $0.017-0.02$ \\
\hline Diazinon & 39572 & 0.005 & 0.003 & Terbufos & 82675 & $0.012-0.017$ & $0.006-0.009$ \\
\hline Diazinon-d10 (surrogate) & 91063 & $0.1 \mathrm{pct}$ & NA & Thiobencarb & 82681 & $0.0048-0.01$ & $0.0024-0.005$ \\
\hline Fipronil sulfide & 62167 & $0.005-0.013$ & 0.006 & & & & \\
\hline Fipronil sulfone & 62168 & $0.005-0.024$ & 0.012 & & & & \\
\hline Fonofos & 04095 & $0.0027-0.006$ & $0.0013-0.003$ & & & & \\
\hline Lindane & 39341 & $0.0040-0.004$ & $0.0020-0.002$ & & & & \\
\hline Linuron & 82666 & $0.035-0.06$ & $0.018-0.03$ & & & & \\
\hline Malathion & 39532 & $0.016-0.027$ & $0.008-0.014$ & & & & \\
\hline
\end{tabular}

${ }^{1}$ Alpha hexachlorocyclohexane.

22-chloro-4-isopropylamino-6-amino-s-triazine.

${ }^{3}$ Dimethyl-2,3,5,6-tetrachlorobenzene-1,4-dicarboxylic acid.

${ }^{4}$ S-ethyl dipropylthiocarbamate.

${ }^{5}$ p,p'-dichlorodiphenyldichloroethylene. 
Table 8. Pesticides analyzed using graphitized carbon-based solid-phase extraction and high-performance liquid chromatography/mass spectrometry at the U.S. Geological Survey National Water Quality Laboratory in Denver, Colorado, in May 2003.

[NWIS, National Water Information System; bolding of compound names denotes permanently estimated values in May 2003 resulting from low recoveries or high variability in lab reagent spikes; pct, percent; NA, not available; these compounds were analyzed for 10 samples collected for the baseline assessment of the Blue Ridge crystalline and Triassic Lowland siliciclastic hydrogeologic setting]

\begin{tabular}{|c|c|c|c|c|c|c|c|}
\hline Compound & $\begin{array}{c}\text { NWIS } \\
\text { Parameter } \\
\text { Code }\end{array}$ & $\begin{array}{l}\text { Minimum } \\
\text { reporting } \\
\text { level, } \\
\text { in } \\
\text { micrograms } \\
\text { per liter }\end{array}$ & $\begin{array}{l}\text { Method } \\
\text { detection } \\
\text { limit, in } \\
\text { micrograms } \\
\text { per liter }\end{array}$ & Compound & $\begin{array}{c}\text { NWIS } \\
\text { Parameter } \\
\text { Code }\end{array}$ & $\begin{array}{l}\text { Minimum } \\
\text { reporting } \\
\text { level, } \\
\text { in } \\
\text { micrograms } \\
\text { per liter }\end{array}$ & $\begin{array}{c}\text { Method } \\
\text { detection } \\
\text { limit, in } \\
\text { micrograms } \\
\text { per liter }\end{array}$ \\
\hline 2,4,5-T (surrogate) & 99958 & $0.1 \mathrm{pct}$ & $0.1 \mathrm{pct}$ & Diphenamid & 04033 & 0.0264 & NA \\
\hline $2,4-\mathrm{D}^{1}$ & 39732 & .0218 & NA & Diuron & 49300 & .015 & NA \\
\hline 2,4-D methyl ester & 50470 & .0086 & NA & Fenuron & 49297 & .0316 & NA \\
\hline $2,4-\mathrm{DB}^{2}$ & 38746 & .016 & NA & Flumetsulam & 61694 & .011 & NA \\
\hline 3(4-Chlorophenyl)-1-methyl urea & 61692 & .0242 & NA & Fluometuron & 38811 & .031 & NA \\
\hline Acifluorfen & 49315 & .0066 & NA & Imazaquin & 50356 & .016 & NA \\
\hline Aldicarb & 49312 & .04 & NA & Imazethapyr & 50407 & .017 & NA \\
\hline Aldicarb sulfone & 49313 & .02 & NA & Imidacloprid & 61695 & .0068 & NA \\
\hline Aldicarb sulfoxide & 49314 & .0082 & NA & Linuron & 38478 & .0144 & NA \\
\hline Atrazine & 39632 & .009 & NA & $\mathrm{MCPA}^{7}$ & 38482 & .0162 & NA \\
\hline 2-Hydroxyatrazine (OIET) ${ }^{3}$ & 50355 & .008 & NA & $\mathrm{MCPB}^{8}$ & 38487 & .015 & NA \\
\hline Deethylatrazine (CIAT) ${ }^{4}$ & 04040 & .0282 & NA & Metalaxyl & 50359 & .02 & NA \\
\hline Deethyldeisopropylatrazine (CAAT) ${ }^{5}$ & 04039 & .01 & NA & Methiocarb & 38501 & .008 & NA \\
\hline Deisopropylatrazine (CEAT) ${ }^{6}$ & 04038 & .044 & NA & Methomyl & 49296 & .0044 & NA \\
\hline Barban (surrogate) & 90640 & $.1 \mathrm{pct}$ & $.1 \mathrm{pct}$ & Metsulfuron methyl & 61697 & .025 & NA \\
\hline Bendiocarb & 50299 & .0252 & NA & Neburon & 49294 & .012 & NA \\
\hline Benomyl & 50300 & .0038 & NA & Nicosulfuron & 50364 & .013 & NA \\
\hline Bensulfuron-methyl & 61693 & .0158 & NA & Norflurazon & 49293 & .016 & NA \\
\hline Bentazon & 38711 & .011 & NA & Oryzalin & 49292 & .0176 & NA \\
\hline Bromacil & 04029 & .033 & NA & Oxamyl & 38866 & .0122 & NA \\
\hline Bromoxynil & 49311 & .017 & NA & Picloram & 49291 & .0198 & NA \\
\hline Caffeine & 50305 & .0096 & .0048 & Propham & 49236 & .0096 & NA \\
\hline Caffeine-C13 (surrogate) & 99959 & $.1 \mathrm{pct}$ & $.1 \mathrm{pct}$ & Propiconazole & 50471 & .021 & NA \\
\hline Carbaryl & 49310 & .0284 & .0142 & Propoxur & 38538 & .008 & NA \\
\hline Carbofuran & 49309 & .0056 & NA & Siduron & 38548 & .0168 & NA \\
\hline 3-Hydroxycarbofuran & 49308 & .0058 & NA & Sulfometuron-methyl & 50337 & .0088 & NA \\
\hline 3-Ketocarbofuran & 50295 & 1.5 & NA & Tebuthiuron & 82670 & .0062 & NA \\
\hline Chloramben, methyl ester & 61188 & .018 & NA & Terbacil & 04032 & .0098 & NA \\
\hline Chlorimuron-ethyl & 50306 & .0096 & NA & Triclopyr & 49235 & .0224 & NA \\
\hline Chlorothalonil & 49306 & .035 & .0173 & & & & \\
\hline Clopyralid & 49305 & .0138 & N/A & & & & \\
\hline Cycloate & 04031 & .013 & NA & & & & \\
\hline Dacthal monoacid & 49304 & .0116 & NA & & & & \\
\hline Dicamba & 38442 & .0128 & NA & & & & \\
\hline Dichlorprop & 49302 & .0138 & NA & & & & \\
\hline Dinoseb & 49301 & .012 & NA & & & & \\
\hline
\end{tabular}

${ }^{1}(2,4$-dichlorophenoxy) acetic acid.

24-(2,4-dichlorophenoxy) butyric acid.

32-hydroxy-4-isopropylamino-6-ethylamino-s-triazine.

42-chloro-4-isopropylamino-6-amino-s-triazine.

${ }^{5}$ Chloro-di-amino-s-triazine.

${ }^{6}$ 2-chloro-6-ethylamino-4-amino-s-traizine.

72-methyl-4-chlorophenoxyacetic acid.

${ }^{8} 4$-(2-methyl-4-chlorophenoxy) butyric acid. 
Table 9. Acetamide, triazine, and phenylurea pesticides and degradation products analyzed using solid-phase extraction and liquid chromatography/mass spectrometry at the U.S. Geological Survey Organic Geochemistry Research Laboratory (OGRL) in Lawrence, Kansas, from August to September 2005 and June 2006.

[NWIS, National Water Information System; *, degradation product; ESA, ethane sulfonic acid; OXA, oxanilic acid; SAA, sulfynil acetic acid]

\begin{tabular}{|c|c|c|c|c|c|}
\hline Analyte & $\begin{array}{c}\text { NWIS } \\
\text { parameter } \\
\text { code }\end{array}$ & $\begin{array}{l}\text { Minimum } \\
\text { reporting } \\
\text { level, } \\
\text { in } \\
\text { micrograms } \\
\text { per liter }\end{array}$ & Analyte & $\begin{array}{c}\text { NWIS } \\
\text { parameter } \\
\text { code }\end{array}$ & $\begin{array}{l}\text { Minimum } \\
\text { reporting } \\
\text { level, } \\
\text { in } \\
\text { micrograms } \\
\text { per liter }\end{array}$ \\
\hline \multicolumn{3}{|l|}{ Acetamide parents and degradation products: } & \multicolumn{3}{|c|}{ Triazine and phenylurea parents and degradation products: } \\
\hline Acetochlor & 49260 & 0.02 & Atrazine & 39632 & 0.025 \\
\hline *Acetochlor ESA & 61029 & .02 & Bromacil & 04029 & .025 \\
\hline *Acetochlor OXA & 61030 & .02 & Cyanazine & 04041 & .025 \\
\hline *Acetochlor SAA & 62847 & .02 & Prometon & 04037 & .025 \\
\hline *Acetochlor/metolachlor ESA - 2nd amide & 62850 & .02 & Propazine & 38535 & .025 \\
\hline$*$ Acetochlor/metolachlor - 2nd amide ${ }^{1}$ & 63782 & .02 & Simazine & 04035 & .025 \\
\hline *Acetochlor deschloro ${ }^{1}$ & 63778 & .02 & *Deethylatrazine $(\mathrm{CIAT})^{2}$ & 04040 & .025 \\
\hline *Acetochlor hydroxy ${ }^{1}$ & 63784 & .02 & *Deisopropylatrazine $(\mathrm{CEAT})^{3}$ & 04038 & .025 \\
\hline Alachlor & 46342 & .02 & $\begin{array}{l}\text { *Hydroxyatrazine or } \\
\text { 2-hydroxyatrazine }(\mathrm{OIET})^{4}\end{array}$ & 50355 & .025 \\
\hline *Alachlor ESA & 50009 & .02 & *Hydroxysimazine & 63154 & .025 \\
\hline *Alachlor OXA & 61031 & .02 & *Deethylhydroxyatrazine (OIAT) $)^{5}$ & 62676 & .025 \\
\hline *Alachlor SAA & 62848 & .02 & *Deisopropylhydroxyatrazine $(\mathrm{OEAT})^{6}$ & 62678 & .025 \\
\hline *Alachlor ESA - 2nd amide & 62849 & .02 & $\begin{array}{r}\text { *Deethyldeisopropylatrazine/ } \\
\text { Didealkyatrazine (CAAT) }{ }^{7}\end{array}$ & 04039 & .025 \\
\hline${ }^{*}$ Alachlor -2 nd amide ${ }^{1}$ & 63781 & .02 & *Cyanazine acid & 61745 & .025 \\
\hline${ }^{*}$ Alachlor deschloro ${ }^{1}$ & 63777 & .02 & *Cyanazine amide & 61709 & .025 \\
\hline *Alachlor hydroxy ${ }^{1}$ & 63783 & .02 & *Deethylcyanazine acid & 61750 & .025 \\
\hline Dimethenamid & 61588 & .02 & *Deethylcyanazine amide & 61751 & .025 \\
\hline *Dimethenamid ESA & 61951 & .02 & *Deethylcyanazine & 61749 & .20 \\
\hline *Dimethenamid OXA & 62482 & .02 & Diuron & 50374 & .20 \\
\hline *Dimethenamid deschloro ${ }^{1}$ & 63779 & .02 & Fluometuron & 38811 & .20 \\
\hline * Dimethenamid hydroxy ${ }^{1}$ & 64045 & .02 & *Demethylfluometuron (DMFM) & 61755 & .20 \\
\hline Flufenacet & 62481 & .02 & Linuron & 38478 & .20 \\
\hline *Flufenacet ESA & 61952 & .02 & & & \\
\hline *Flufenacet OXA & 62483 & .02 & & & \\
\hline Metolachlor & 39415 & .02 & & & \\
\hline *Metolachlor ESA & 61043 & .02 & & & \\
\hline *Metolachlor OXA & 61044 & .02 & & & \\
\hline${ }^{*}$ Metolachlor deschloro ${ }^{1}$ & 63780 & .02 & & & \\
\hline *Metolachlor hydroxy ${ }^{1}$ & 63785 & .02 & & & \\
\hline Propachlor & 04024 & .02 & & & \\
\hline *Propachlor ESA & 62766 & .05 & & & \\
\hline *Propachlor OXA & 62767 & .02 & & & \\
\hline
\end{tabular}

${ }^{1}$ Unapproved compound as of June 1, 2008 (Michael Meyer, U.S. Geological Survey Organic Geochemistry Research Laboratory, oral commun., 2008).

22-chloro-4-isopropylamino-6-amino-s-triazine.

32-chloro-6-ethylamino-4-amino-s-traizine.

${ }^{4}$ 2-hydroxy-4-isopropylamino-6-ethylamino-s-triazine.

52-hydroxy-4-isopropylamino-6-amino-s-triazine.

62-hydroxy-6-ethylamino-4-amino-s-triazine.

${ }^{7}$ Chlorodiamino-s-triazine. 


\section{Quality Assurance and Quality Control}

A USEPA-approved Quality Assurance Project Plan (QAPP) (U.S. Environmental Protection Agency, 2000a) was implemented to obtain data of known and adequate quality specified by documented quality assurance (QA) objectives. The QAPP is on file at the PA WSC office of the USGS in New Cumberland, Pa.

Quality controls for field-instrument calibration as detailed in the QAPP (with the exception of barometric pressure and turbidity) are summarized in table 10. Instruments used to collect specific conductance, $\mathrm{pH}$, dissolved oxygen, and turbidity were calibrated and checked for accuracy on the day of sampling by the use of certified standards and buffers; thermistors for field instruments were checked one time prior to each sampling season.

\section{Quality-Assurance Objectives}

For QC of water-quality samples, QA objectives were established as part of the QAPP to assure the

- Representativeness of samples to characterize the aquifer of interest using site-selection criteria combined with stability criteria for field measurements; the acceptance criteria for representativeness (percent of listed site-selection criteria being met for each well and percent of stability criteria for field measurements being met during well purge prior to sample collection) was not defined in the QAPP (QA objective 1),

- Bias resulting from sample contamination (resulting in false positives) from all processing sources (field processing, transport, and lab analysis) would be zero; the objective would, therefore, only be met if 100 percent of the blanks were without contamination (QA objective 2),

- Bias resulting from not detecting an analyte when the analyte was present would be less than 5 percent (resulting in false negatives) (QA objective 3),

Table 10. Quality-control acceptance criteria for fieldinstrument calibration.

\begin{tabular}{ll}
\hline \multicolumn{1}{c}{ Measurements } & \multicolumn{1}{c}{ Acceptance criteria } \\
\hline Water temperature & \pm 0.5 degrees Celsius \\
Specific conductance & \pm 5 percent \\
$\mathrm{pH}$ & \pm 0.05 units $\mathrm{pH}$ \\
Dissolved oxygen & \pm 5 percent \\
Barometric pressure & \pm 1 percent \\
Turbidity & \pm 2 percent \\
\hline
\end{tabular}

- Bias in analyte recovery would be \pm 25 percent of the 'true' (100-percent) recovery (QA objective 4), and

- Variability in results would be \pm 25 percent (QA objective 5).

The five QA objectives were evaluated through methodology that involved either goals for adherence to wellselection criteria and well-purging stability indicators or QC samples to evaluate bias and (or) variability. QC samples submitted for the project included blanks, replicates, FSRW samples prepared in triplicate, nutrient SRWS, and 2-lab splits. QC data from lab reagent spikes (LRS) were used when data from field-submitted samples were not available. Blank samples help define the (false) positive bias that may be introduced into analytical results through sample contamination, either through improperly cleaned equipment, field processing, or lab processing. Data from replicates provided information on variability in analytical results. FSRW samples, SRWS, and internal laboratory-control data provided information for bias and (or) variability related to compound recovery. Therefore, if compound recoveries were above 100 percent, the results for the environmental samples would be biased high; alternately, if compound recoveries were less than 100 percent, the results for the environmental samples would be biased low. The numbers of QC samples and the respective laboratories used for analyses from 2003 through 2007 are summarized in table 11. Detailed information on methodology and the resulting analysis of QC data for each objective are presented in appendix 2. The following is a summary of the results:

\section{QA objective 1}

Representativeness in sampling: Water samples were considered representative of the aquifer being sampled because site-selection criteria combined with stability criteria for field measurements were met 75 to 100 percent of the time.

\section{QA objective 2}

False positives: There were no detections of pesticides above the method detection limit (MDL) for the three blank samples analyzed at the PADEPL; therefore, no PADEPL results for environmental samples analyzed had a positive bias because of sample contamination. For samples submitted to the NWQL, 1 field-blank pesticide sample of the 11 equipment and field blank samples submitted had an estimated (E) detection of p,p'-DDE (E $0.0009 \mu \mathrm{g} / \mathrm{L})$, which was below the MDL $(0.001 \mu \mathrm{g} / \mathrm{L})$ and the MRL $(0.003 \mu \mathrm{g} / \mathrm{L})$ for this compound. It was unclear if the contamination was introduced from the air during sample collection or during analysis at the laboratory. Insufficient cleaning of equipment was discounted because p,p'-DDE was not detected in any of the wells sampled during the years of sample collection. For all intents and purposes, there was no contamination in blank samples for any pesticides analyzed at the NWQL except p,p'-DDE.

Of the 12 nitrate blank samples submitted to the PADEPL, only three had detections at or above the MRL 
Table 11. Summary of the numbers of quality-control samples analyzed at the U.S. Geological Survey (USGS) National Water Quality Laboratory (NWQL), USGS Ohio Water Microbiology Laboratory (OWML), the USGS Organic Geochemistry Research Laboratory (OGRL), and the Pennsylvania Department of Environmental Protection Laboratory (PADEPL), 2003-07.

[E. coli, Escherichia coli]

\begin{tabular}{llc}
\hline \multicolumn{1}{c}{$\begin{array}{c}\text { Quality-control } \\
\text { sample type }\end{array}$} & $\begin{array}{c}\text { Laboratory } \\
\text { used }\end{array}$ & $\begin{array}{c}\text { Number of } \\
\text { samples }\end{array}$ \\
\hline Equipment blanks & \\
\hline Pesticides & PADEPL & 1 \\
& NWQL & 4 \\
\hline Nitrate plus nitrite/ & PADEPL & 2 \\
nitrate and (or) nitrite & NWQL & 1 \\
\hline Total coliform and $E$. coli bacteria & PADEPL & 1 \\
& OWML & 1
\end{tabular}

\begin{tabular}{llr}
\hline \multicolumn{2}{c}{ Field blanks } & \\
\hline Pesticides & PADEPL & 2 \\
& NWQL & 7 \\
\hline Nitrate plus nitrite/ & PADEPL & 10 \\
nitrate and (or) nitrite & NWQL & 1 \\
\hline Total coliform and E. coli bacteria & PADEPL & 6 \\
& OWML & 4
\end{tabular}

\begin{tabular}{lll}
\hline \multicolumn{2}{c}{ Trip blanks } & \\
\hline Nitrate plus nitrite/ & PADEPL & 0 \\
nitrate and (or) nitrite & NWQL & 1 \\
\hline Total coliform and E. coli bacteria & PADEPL & 0 \\
& OWML & 1
\end{tabular}

\begin{tabular}{llr}
\hline \multicolumn{3}{c}{ Replicates } \\
\hline $\begin{array}{llr}\text { Nitrate plus nitrite/ } \\
\text { nitrate and (or) nitrite }\end{array}$ & PADEPL & 20 \\
\hline Total coliform and E. coli bacteria & NWQL & 2 \\
\hline & OWDEPL & 34 \\
& OWML & 2 \\
\hline
\end{tabular}

Field-spiked reagent water samples, prepared in triplicate

\begin{tabular}{llr}
\hline Pesticides & PADEPL & 18 \\
& NWQL & 36 \\
& OGRL & 4 \\
\hline $\begin{array}{l}\text { Nitrate plus nitrite/ } \\
\text { nitrate and (or) nitrite }\end{array}$ & PADEPL & 12 \\
\hline \multicolumn{2}{c}{ Nutrient standard reference samples } \\
\hline Nitrate and nitrite & PADEPL & 3 \\
\hline \multicolumn{2}{c}{ 2-lab split samples } \\
\hline $\begin{array}{l}\text { Pesticides } \\
\text { NADEPL }\end{array}$ \\
\hline $\begin{array}{l}\text { Nitrate plus nitrite/ } \\
\text { nitrate and (or) nitrite }\end{array}$ & 3 \\
\hline Total coliform and $E$. coli bacteria & OWML & 2 \\
\hline
\end{tabular}

$(0.04 \mathrm{mg} / \mathrm{L})$. One field blank in 2004 had a concentration of $0.2 \mathrm{mg} / \mathrm{L}$; the remaining two analyses (one collected in 2005 and one in 2006) reported nitrate concentrations at the MRL $(0.04 \mathrm{mg} / \mathrm{L})$. The $0.2 \mathrm{mg} / \mathrm{L}$ reported concentration in one blank was considered an isolated case where the equipment was not cleaned properly after one sample, because the sample collected the following day had no nitrate concentration above the MRL. Because of the three detections of nitrate above the MRL, reported concentrations of nitrate analyzed at the PADEPL may contain minimal positive bias (usually about $0.04 \mathrm{mg} / \mathrm{L}$ ) resulting from sample contamination during collection, processing, or laboratory analysis. Nitrate was not detected above the MRL in the three blank samples analyzed at the NWQL; therefore, environmental results (April 2003May 2003) do not have a positive bias because of sample contamination.

Bacteria were not detected in the seven blank samples submitted to the PADEPL or in the six blank samples submitted to the USGS OWML. Sterile buffered water with peptone is known to result in some false positives (Amie Brady, U.S. Geological Survey, oral commun., December 21, 2007); however, that result was not observed in this study. The goal of no false positives was met for the bacteria results.

\section{QA objective 3}

False negatives (spiked compounds that are not reported when the compounds are present should be less than 5 percent): There was a false negative for 1 (captan) of the 65 pesticides evaluated in FSRW samples and no false negatives for nitrate plus nitrite or total coliform/E. coli bacteria. Relative to the "less than 5 percent" goal for QA objective 3, captan had a bias of 100 percent because it was not reported in any spikes, and all other pesticides had zero bias. Nitrate and nitrite analyses and total coliform and $E$. coli bacteria results all met project goals (zero bias).

\section{QA objective 4}

Bias in recovery should be \pm 25 percent of the 'true' value (at a $0.4 \mu \mathrm{g} / \mathrm{L}$ concentration for most pesticides evaluated).

\section{Bias results for pesticide samples analyzed at the NWQL:}

- Of the 60 pesticides included in triplicate FSRW samples analyzed at the NWQL (table 2-2, appendix 2) (surrogates not included in count), the following 17 compounds had low biases that did not meet project objectives: aldicarb, alicarb sulfone, aldicarb sulfoxide, deethylatrazine (CIAT), cis-permethrin, desulfinylfipronil amide, 2,6-diethylaniline, disulfoton, ethalfluralin, methiocarb, methomyl, metribuzin, oxamyl, p,p'-DDE, phorate, propargite, and terbacil. The compound 2, 6-diethylaniline also had poor median recovery ( 33 percent) in FSRW samples but 
excellent recovery and variability in LRS. The poor recoveries in FSRW samples could have been the result of methodology or equipment used in spike preparation because 2, 6-diethylaniline is very volatile (Lucinda Murtagh, U.S. Geological Survey, oral commun., December 19, 2007); therefore, this compound will not be qualified on the basis of the FSRW results. Median recoveries for these pesticides ranged from 11 to 74 percent.

- Of the 47 compounds not included in FSRW samples analyzed at the NWQL (table 2-2, appendix 2), 20 compounds did not meet project bias goals on the basis of the "long-term" median recoveries from LRS. Bensulfuron-methyl, chlorimuron-ethyl, flumetsulam, imazaquin, nicosulfuron, and sulfometuron-methyl had high biases ranging from 130 to 205 percent (table 2-2, appendix 2). The following 14 compounds had low biases in median recoveries ranging from 7 to 73 percent (table 2-2, appendix 2): 2,4-DB, deisopropylatrazine (CEAT), bendiocarb, bentazon, bromoxynil, 3-keto-carbofuran, chloramben methyl ester, deethyldeisopropylatrazine (CAAT), chlorothalonil, clopyralid, cycloate, dinoseb, metsulfuron-methyl, and MCPB.

Bias results for pesticide samples analyzed at the PADEPL:

- Of the 20 pesticides included in FSRW samples analyzed at the PADEPL (table 2-2, appendix 2) (surrogates not included in count), the following 3 compounds had low recoveries that did not meet project objectives: captan, hexachlorocyclopentadiene, and metribuzin. Median recoveries for these pesticides ranged from 0 to 72 percent.

- Three compounds analyzed at the PADEPL were not included in the FSRW samples - dichlobenil, fenpropathrin, and phosmet (table 2-2, appendix 2). For these compounds, median recoveries from LRS were used to evaluate bias; all lab median recoveries of LRS were within project goals for these compounds.

Bias results for pesticide samples analyzed at the OGRL laboratory:

- Of the 10 pesticides included in the FSRW samples sent to the USGS OGRL (acetochlor, alachlor, metolachlor, propachlor, atrazine, cyanazine, prometon, simazine, CIAT, and linuron), all compounds analyzed met project QA objective 4 goals except atrazine, prometon, simazine, and CIAT, which showed low biases in recoveries ranging from 62 to 74 percent (table 2-3).
Bias results for nitrate and nitrite samples analyzed at the $N W Q L$ and the PADEPL:

- Results were good at both laboratories: There was a negative bias of 1-2 percent for nitrate and 0-percent bias for nitrite. Therefore, bias was well within the \pm 25 percent goal for both compounds.

Bias results for total coliform and E. coli results analyzed at the PADEPL:

- No total coliform or E. coli samples were submitted as spiked samples because of the wide confidence limits associated with the Colilert-tray methodology; therefore, bias was not evaluated.

\section{QA objective 5}

Variability in results would be \pm 25 percent: For pesticides, two data sets were used to evaluate variability of pesticides included in spike mixes: 1) median relative standard deviations (RSDs), which were calculated using individual pesticides concentrations from triplicate sets, and 2) F-pseudosigma for FSRW and LRS recoveries. F-pseudosigma is a nonparametric statistic defined as the interquartile range of data divided by 1.349 (Hoaglin and others, 1983).

\section{Variability results for pesticide samples analyzed at the} $N W Q L$ :

- Using median RSDs calculated from concentrations of pesticides in triplicate FSRW samples for 60 pesticides analyzed at the NWQL (table 2-2, appendix 2) (surrogates not included in count), the goal of variability was met for all pesticides except the following: aldicarb, aldicarb sulfoxide, methiocarb, and methomyl. RSDs for these four compounds ranged from 26 to 93 percent. Using the F-pseudosigma results from aggregated compound recoveries from FSRW samples analyzed at the USGS NQWL, four compounds-azinphos-methyl, carbaryl, 2,6-diethylaniline, and fipronil-did not meet project objectives for variability. F-pseudosigmas for recoveries of these compounds ranged from 27 to 59 percent. The goal in variability was met for 93 percent of the compounds on the basis of RSD criteria and 93 percent on the basis of F-pseudosigmas of recoveries. Again, 2,6-diethylaniline results were not qualified due to the methodology or equipment used in spike preparation, which may have affected results.

- For the 47 pesticides not included in FSRW samples analyzed at the NWQL, the goal in variability was met for 70 percent of the compounds on the basis of F-pseudosigma of recoveries in LRS (table 2-2). Those 13 pesticides not meeting project objectives 
for variability were bensulfuron-methyl, bentazon, bromacil, bromoxynil, chloramben methyl ester, chlorimuron-ethyl, cycloate, flumetsulam, imazaquin, imazethapyr, metsulfuron-methyl, nicosulfuron, and norflurazon. F-pseudosigmas on LRS recoveries ranged from 27 to 50 percent.

Variability results for pesticide samples analyzed at the PADEPL:

- Using the median RSDs calculated from concentrations of pesticides in triplicate FSRW samples for 20 pesticides analyzed at the PADEPL (table 2-2, appendix 2) (surrogates not included in count), the goal for variability was met for all pesticides analyzed that could be evaluated. The exception was captan - no concentrations were reported in the spiked samples above the MRL. Captan, therefore, was not qualified based on the variability in LRS (37 percent). Using the F-pseudosigma statistic calculated for samples analyzed at the PADEPL for individual compound recoveries, the goal was also met for all pesticides analyzed except azinphos-methyl (F-pseudosigma for this compound was 78 percent).

- For the three pesticides that were not included in FSRW samples analyzed at the PADEPL_-dichlobenil, fenpropathrin, and phosmet. F-pseudosigmas for LRS recoveries for fenpropathrin (36 percent) and phosmet (47 percent) did not meet project objectives (table 2-2).

Variability results for pesticide samples analyzed at the OGRL:

- For the 10 pesticides in the triplicate FSRW samples sent to the USGS OGRL, only concentrations of linuron had a calculated RSD that did not meet QA objective 5 (44 percent). RSDs for all other compounds ranged from 0 to 24 percent.

Variability results for nitrate and nitrite samples analyzed at the NWQL and PADEPL:

- For nitrate and nitrite, the QA objective was met 100 percent of the time. Median RSDs of nitrate and nitrite replicate concentrations ranged from 0 to 2 percent and F-pseudosigmas of nitrate and nitrite recoveries ranged from 1 to 5 percent.

Variability results for total coliform and E. coli results analyzed at the PADEPL:

- For total coliform bacteria, a median RSD of 25 percent for well-water replicate samples met the QA objective for variability. Variability in E. coli results could not be evaluated because of infrequent detections in the samples submitted.

\section{Qualifying Sample Results Based on Quality- Assurance Objectives}

Estimates of bias and variability in reported concentrations (table 2-2) were used to 'qualify' selected results because QA objectives 4 and (or) 5 were not met. 'Qualified' concentrations may substantially differ from the true environmental concentrations because of poor performance of bias and variability using either field-submitted QC samples and (or) internally submitted laboratory QC samples. The effects of environmental-water chemistry in the respective well-water sample may increase or decrease bias and variability for individual compounds.

$P A D E P L$ - Twenty-three pesticides were analyzed at the PADEPL (table 6). Of these pesticide compounds, results for azinphos-methyl, captan, fenpropathrin, hexachlorocyclopentadiene, metribuzin, and phosmet were qualified on the basis of the results of six to nine project-submitted QC samples and (or) internally submitted QC samples. No reported concentrations in environmental samples were above the respective MRLs for any of these seven compounds when analyzed by the PADEPL, and it is possible, therefore, that some of the results reported as less than the MRLs are actually false negatives.

USGS NWQL-Of the 107 pesticide compounds analyzed at the NWQL, 48 compounds did not have results that met project QA objectives; the results for these compounds were qualified. Qualified compounds include those 39 compounds previously identified as permanently "Estimated" (one of several reasons concentrations are flagged with an "E" qualifier in the National Water Information System [NWIS] database) (based on internally submitted QC-sample results) (tables 7 and 8), and ethalfluralin, metribuzin, p,p'-DDE, and propargite were qualified as a result of 33 project-submitted QC-sample results. Results for five other pesticides were also qualified, 2,4-DB, bendiocarb, clopyralid, MCPB, and sulfometuron-methyl, which were not qualified as estimated in 2003 but which had internally submitted QC-sample results that did not meet project QA objectives. Of the 48 compounds, CIAT was reported above the MRL in 81 samples. Ten or fewer environmental samples had reported concentrations of terbacil, carbofuran, carbaryl, benomyl, deisopropylatrazine (CEAT), CAAT, dinoseb, norflurazon, and sulfometuronmethyl. The other qualified compounds were not reported above the respective MRLs in any of the samples analyzed; it is possible that some of the results were actually false negatives.

USGS OGRL - Of the 54 pesticide compounds analyzed at the USGS OGRL (table 9), 10 pesticide compounds (acetochlor, alachlor, metolachlor, propachlor, atrazine, cyanazine, prometon, simazine, CIAT, and linuron) were 
submitted in four project-submitted QC samples for evaluation of bias and variability (table 2-3). All compounds but linuron (RSD was 44 percent) met project QA goals for variability (no environmental samples had concentrations above the MRL), and all compounds but atrazine, prometon, simazine, and CIAT (low recoveries ranging from 62 to 74 percent) met project goals for bias (concentrations were reported above the MRLs). Linuron, atrazine, prometon, simazine, and CIAT results are noted as not meeting project QA goals but were not qualified because of the low numbers of project-submitted QC samples and the lack of long-term QC results for comparison.

\section{Pesticides in Ground Water for the Baseline Assessment of Hydrogeologic Settings, 2003-07}

Well-water samples were collected for the baseline assessment of hydrogeologic settings to identify occurrence and concentrations of pesticides in ground water from settings where few or no previous sample analyses for pesticides were available (Lindsey and Bickford, 1999). The following section describes the results from samples for 2003-07 (appendix 3).

\section{Blue Ridge Crystalline and Triassic Lowland Siliciclastic}

Twenty rural domestic wells were sampled in the Blue Ridge crystalline and Triassic Lowland siliciclastic setting in 2003. Of these 20 wells, 13 were in the Blue Ridge crystalline part of the setting, and 7 were in the western boundary of the Triassic Lowland siliciclastic part of the setting. Ten of the wells were randomly sampled in May 2003, and these samples were analyzed at the USGS NWQL (tables 7 and 8; MRLs ranged from 0.002 to $1.5 \mu \mathrm{g} / \mathrm{L}$ ). The remaining 10 well samples were collected in August through September 2003; these samples were analyzed at the PADEPL (table 6; MRLs ranged from 0.10 to $1.6 \mu \mathrm{g} / \mathrm{L}$ ). The MRLs are, therefore, higher for analyses completed at the PADEPL (table 6); fewer compounds were analyzed at the PADEPL than at the USGS NWQL (tables 7 and 8). The results presented for this setting should be considered relative to these two issues. No concentrations of pesticides were above $0.10 \mu \mathrm{g} / \mathrm{L}(1.6 \mu \mathrm{g} / \mathrm{L}$ for carbaryl, oxamyl, and methomyl) in samples analyzed at the PADEPL. The well locations in Cumberland County and Adams County, Pa., and laboratories used for analyses of respective samples are shown in figure 8 . For the Blue Ridge crystalline and Triassic Lowland siliciclastic setting, the number of samples with pesticide detections are shown in table 12 .

Concentrations of pesticides in samples collected in this setting are shown in table 13. Six wells had water with concentrations of one or more pesticides at or above the MRLs. Three well-water samples had only 1 pesticide with a concentration equal to or above the respective MRL (wells CU 951, AD 1160, and AD 1162); well AD 1159 had 2 cooccurring pesticides, well AD 1161 had 8 co-occurring pesticides, and well AD 1155 had 16 co-occurring pesticides. The herbicide 2,4-D had the greatest concentration in this setting $($ E $2.52 \mu \mathrm{g} / \mathrm{L})$ followed by $2,4-\mathrm{D}$ methyl ester $(0.663 \mu \mathrm{g} / \mathrm{L})$. CEAT and CAAT (degradation products of atrazine and simazine) were analyzed at the NWQL for 10 samples in the Triassic Lowland siliciclastic setting only; one sample had reported concentrations of CEAT of E $0.17 \mu \mathrm{g} / \mathrm{L}$ and CAAT of $\mathrm{E} 0.25 \mu \mathrm{g} / \mathrm{L}$ even though the concentration of atrazine and CIAT were both less than $0.10 \mu \mathrm{g} / \mathrm{L}$ (table 13). Atrazine and (or) degradates of atrazine and simazine were present in water from five of the six wells at concentrations above the MRLs.

\section{Eastern Lake Surficial}

Twenty rural domestic wells were sampled in the Eastern Lake surficial setting (Erie County, Pa.) from May through August 2004 (fig. 9). Because of an analyst error, the sample extract for one sample (well ER 3506) was lost during preparation. This well was resampled in October 2004. The PADEPL in Harrisburg, Pa., analyzed all samples collected in 2004.

To test well water for pesticide compounds commonly used in grape-growing regions such as the Eastern Lake surficial setting, the PADEPL analyzed samples for four additional compounds (dichlobenil, fenpropathrin, and trifluralin, all with MRLs of $0.10 \mu \mathrm{g} / \mathrm{L}$, and phosmet, MRL of $1.0 \mu \mathrm{g} / \mathrm{L}$ ); therefore, each sample was analyzed for 23 pesticide compounds.

No concentrations of pesticides were above the MRLs (table 6) for any of the 20 well-water samples from the Eastern Lake surficial setting. The low number of reported concentrations may be at least partially explained by the greater PADEPL pesticide MRLs compared to those at the NWQL and the lower number of compounds analyzed at the PADEPL. Additionally, results from the QA samples submitted as FSRW samples in April and June 2004 indicated a negative bias in pesticide recoveries that may characterize the samples submitted the first month of sampling (May) and the entire month of June when samples were analyzed at the PADEPL. Whereas the April and June spikes showed an overall negative bias, the July spikes showed a positive bias with recoveries as high as 260 percent. No FSRW samples were submitted in August to evaluate PADEPL pesticide recoveries.

In addition to the variability bias in recovery, MRLs increased in 2004 for azinphos-methyl (from 0.10 to $0.50 \mu \mathrm{g} / \mathrm{L}$ ), phosphamidon (from 0.10 to $0.25 \mu \mathrm{g} / \mathrm{L}$ ), and the carbamates, carbaryl, oxamyl, and methomyl (from 1.6 to $2.0-5.0 \mu \mathrm{g} / \mathrm{L}$ ). For well ER 3509, analyses for carbaryl, methomyl, and oxamyl were cancelled (per PADEPL report; unknown reason); therefore, no results are available for these compounds. The MRLs for phosphamidon and azinphosmethyl were later reevaluated by PADEPL and set at $1.0 \mu \mathrm{g} / \mathrm{L}$ (Martina McGarvey, Director, Pennsylvania Department 


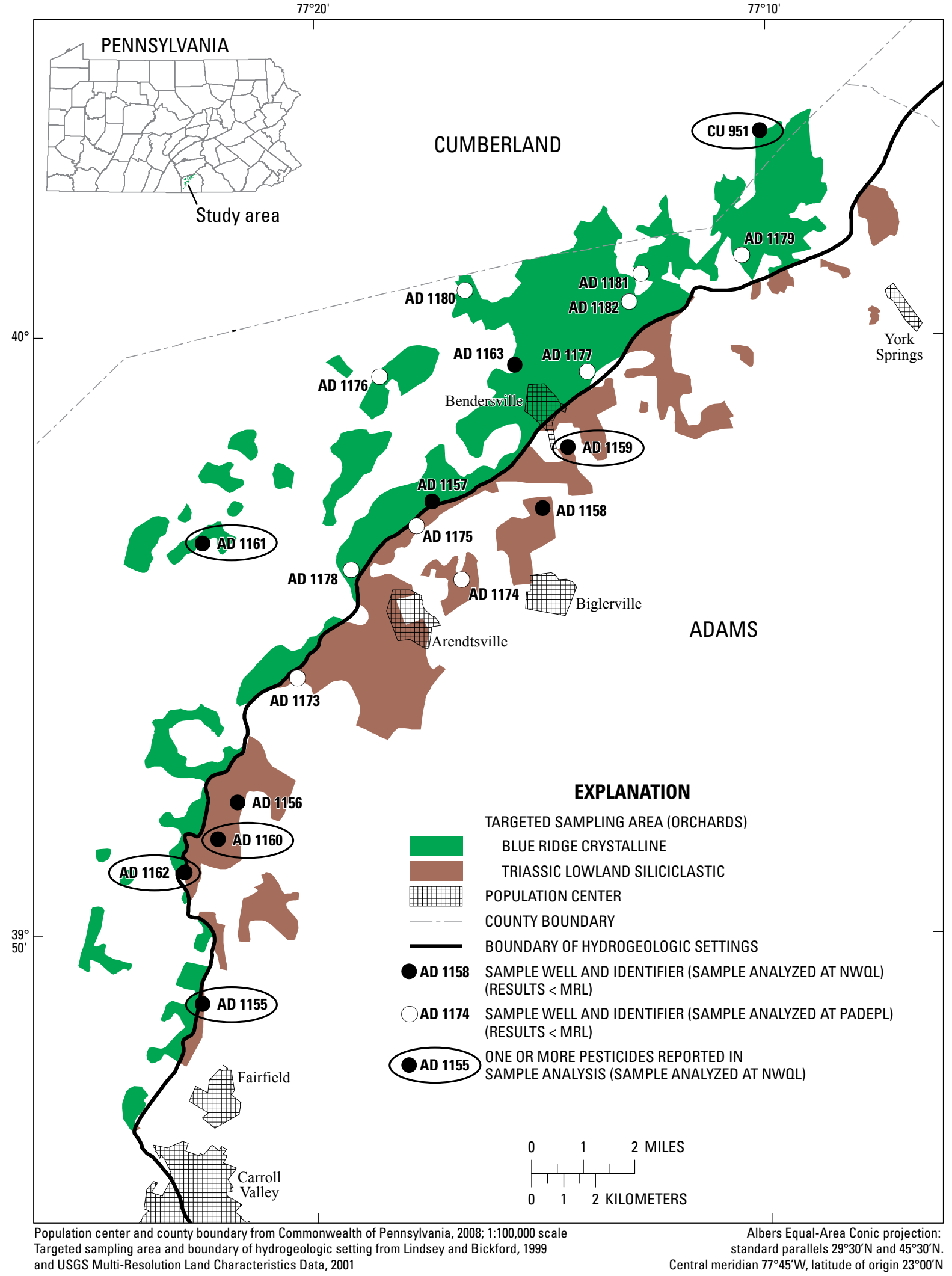

Figure 8. Locations of wells sampled for pesticide analysis and wells with reported concentrations above the minimum reporting levels in the Blue Ridge crystalline and Triassic Lowland siliciclastic hydrogeologic setting, Adams and Cumberland Counties, Pennsylvania, May and August 2003. Minimum reporting levels (MRLs) at the Pennsylvania Department of Environmental Protection Laboratory (PADEPL) ranged from 0.10 to $1.6 \mu \mathrm{g} / \mathrm{L}$, and MRLs at the U.S. Geological Survey National Water Quality Laboratory (NWOL) ranged from 0.002 to $1.5 \mu \mathrm{g} / \mathrm{L}$. The notation $<\mathrm{MRL}$ indicates no pesticides were reported at concentrations at or above the MRL. 


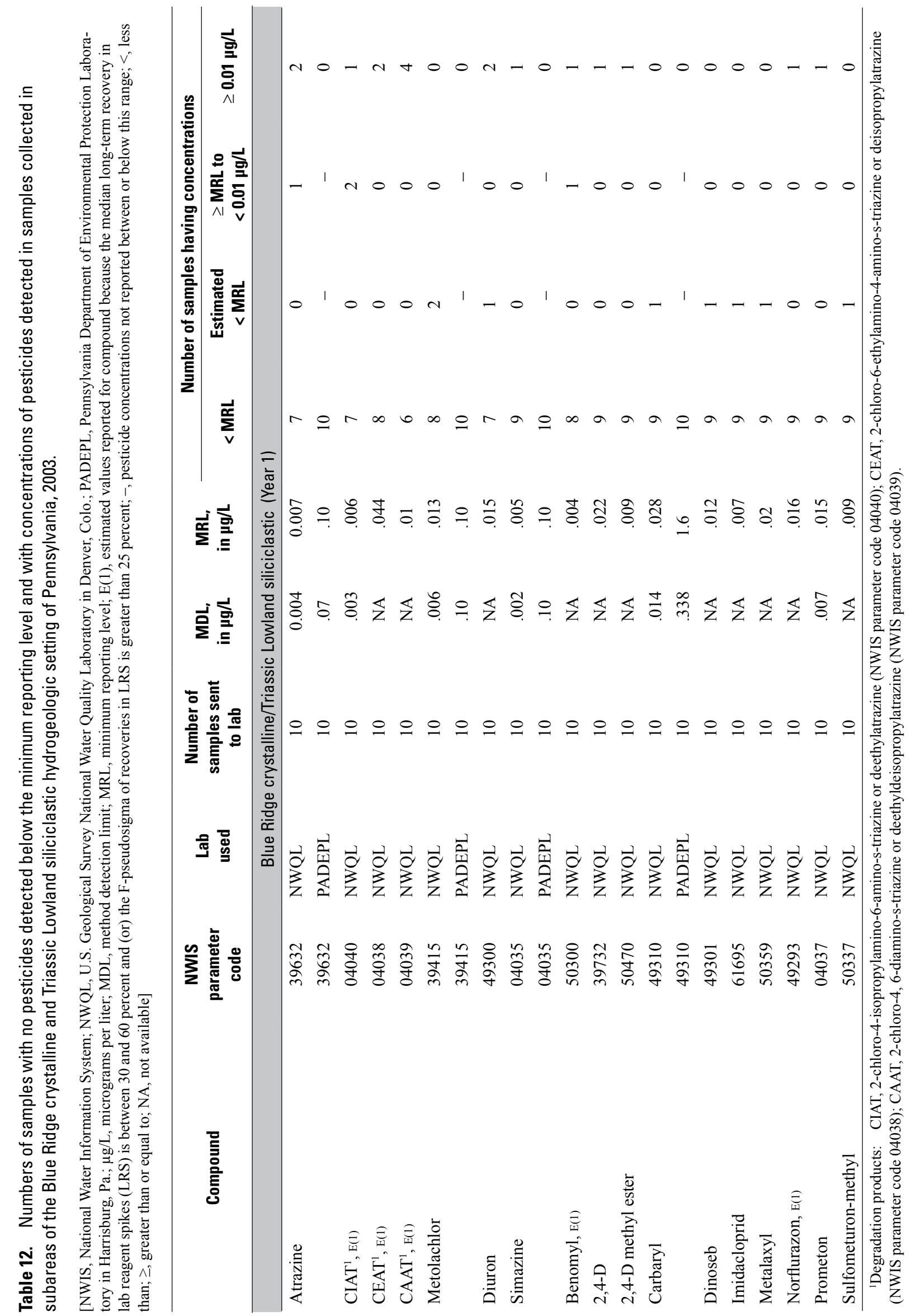




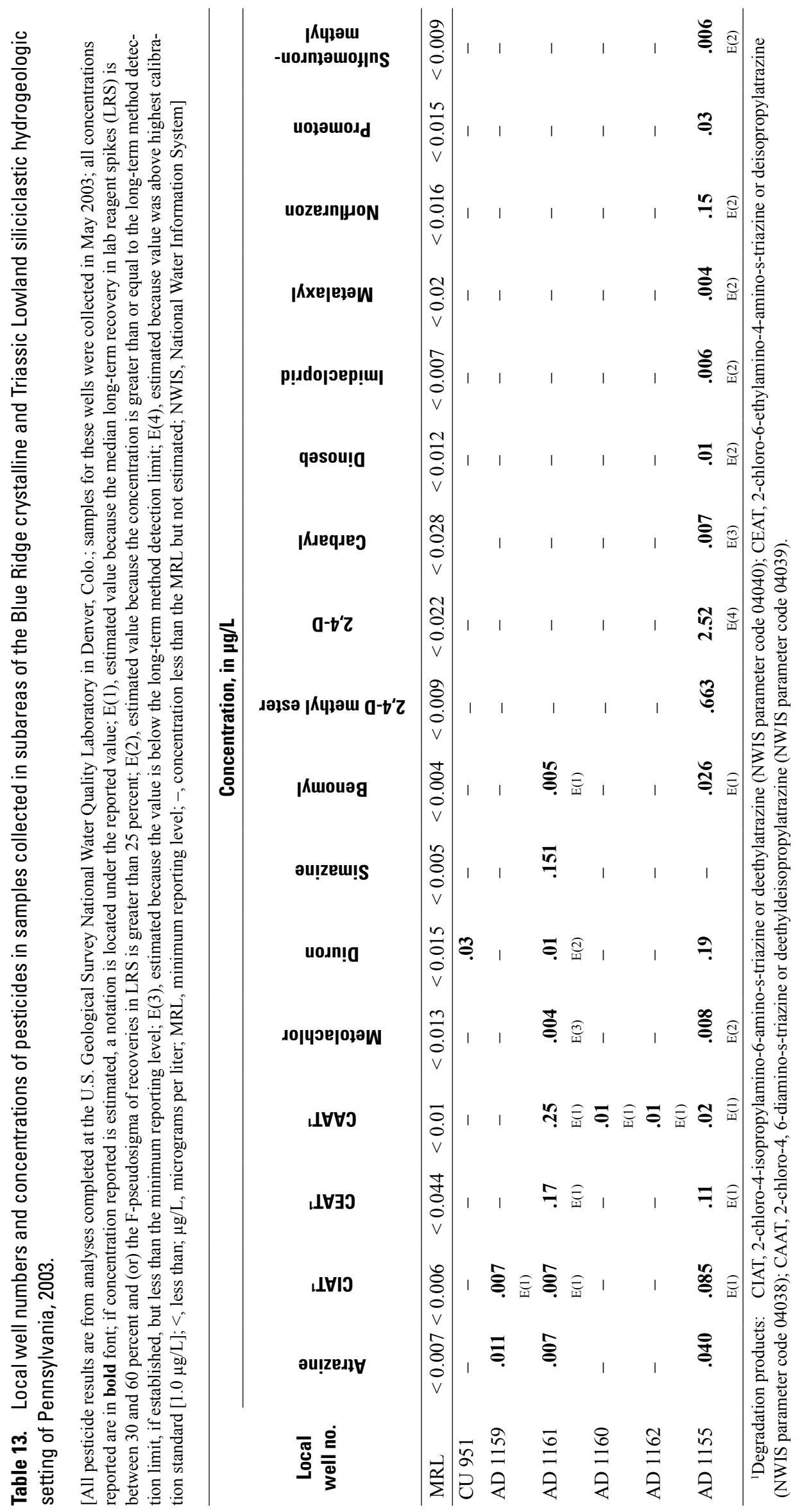



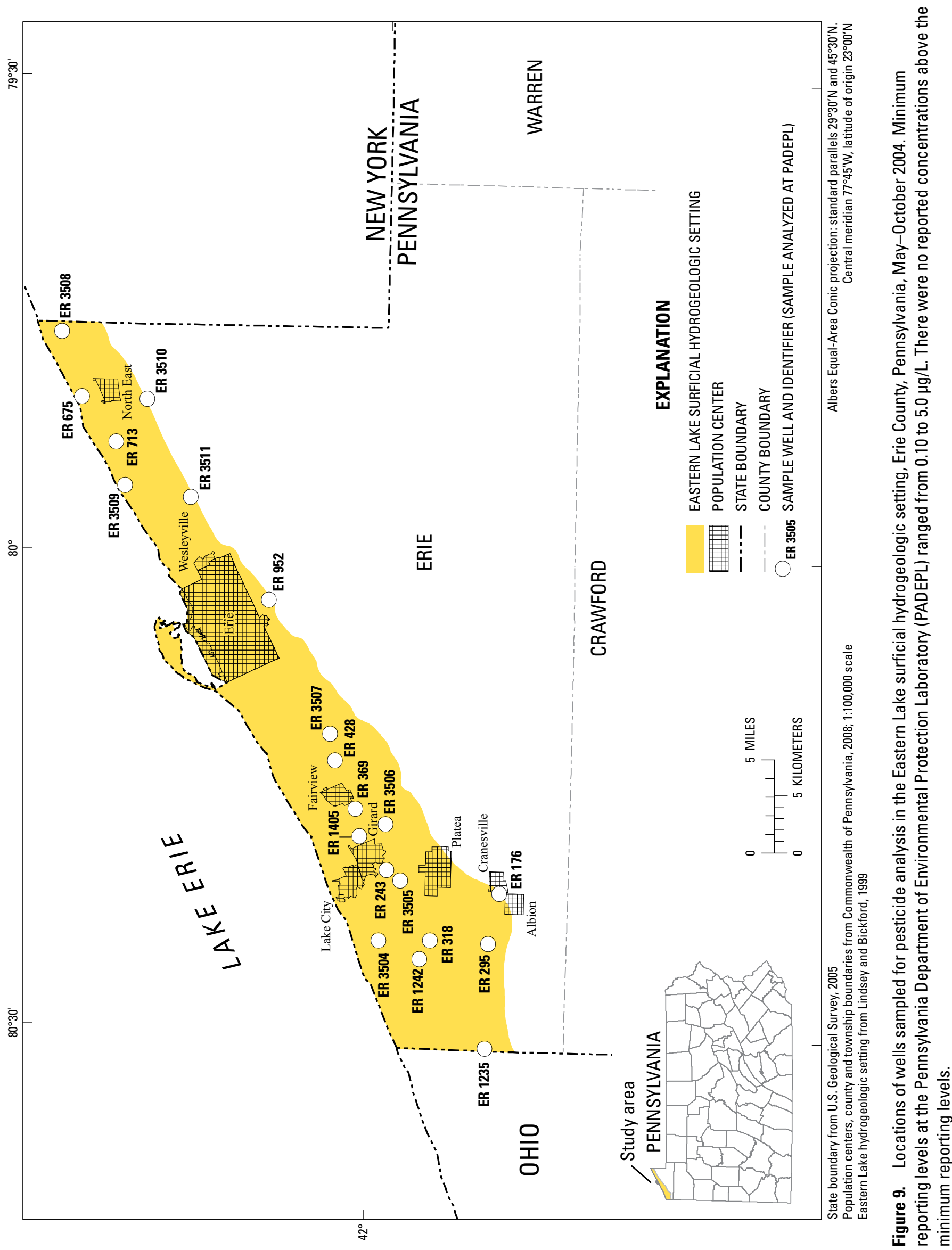
of Environmental Protection Laboratory, written commun., 2007).

The results reported from the Eastern Lake surficial setting are, therefore, limited largely by the greater PADEPL MRLs (compared to those at the NWQL) and cannot be directly compared to numbers of samples with reported concentrations from the Devonian-Silurian carbonate, Great Valley siliciclastic, and Northeastern Glaciated surficial hydrogeologic settings where analytical work was completed at the USGS NWQL.

\section{Devonian-Silurian Carbonate}

Well water was collected and analyzed from 28 rural domestic wells between June and August 2005 in the Devonian-Silurian carbonate setting. All well-water samples and most of the QC samples for pesticides were analyzed at the USGS NWQL for a suite of 52 pesticides (table 7). For the Devonian-Silurian carbonate setting, the numbers of samples with pesticide detections are shown in table 14. In this setting, only well JU 373 had a concentration below the MRL (atrazine, at E $0.004 \mu \mathrm{g} / \mathrm{L}$ ); all other detections of compounds were above the respective MRLs. All the wells in this setting with concentrations above the MRLs had one or more pesticides with concentrations above $0.01 \mu \mathrm{g} / \mathrm{L}$ but less than $0.10 \mu \mathrm{g} / \mathrm{L}$; $0.10 \mu \mathrm{g} / \mathrm{L}$ is the lowest MRL for pesticides analyzed at the PADEPL. Well locations and wells with concentrations of pesticides reported above and below the MRLs are shown in figure 10 .
Sixteen wells had one or more pesticides reported in well-water samples (table 15). Fifteen of these wells showed co-occurrence of atrazine and CIAT, a degradate of atrazine. Three of these 15 wells also had measurable concentrations of simazine, and 1 of the 15 wells had a co-occurrence of metolachlor. Only one well (well JU 271) had a concentration of a single pesticide, acetochlor, at a concentration of $0.029 \mu \mathrm{g} / \mathrm{L}$ (table 15).

Maximum concentrations of atrazine and CIAT were $0.054 \mu \mathrm{g} / \mathrm{L}$ (well UN 205) and E $0.062 \mu \mathrm{g} / \mathrm{L}$ (well HU 429), respectively. Well HU 429 also had the maximum combined concentration of all pesticides reported (as mass per volume $[\mu \mathrm{g} / \mathrm{L}]$ and not normalized to moles per volume) $-0.114 \mu \mathrm{g} / \mathrm{L}$, followed by well LY $688(0.109 \mu \mathrm{g} / \mathrm{L})$ and well UN 206 $(0.104 \mu \mathrm{g} / \mathrm{L})$. Median recoveries in LRS water samples in 2005 for atrazine (105 percent), metolachlor (103 percent), and simazine (99 percent) were \pm 5 percent of the 'true' (100 percent) recovery; assuming negligible interferences from environmental-water chemistry, concentrations of these herbicides in well-water samples are accurate. CIAT, however, had a median recovery of 34 percent in a LRS sample in 2005; therefore, the actual concentrations could be greater than that reported in well-water samples.

Table 14. Number of samples with no pesticides detected below the minimum reporting levels and with concentrations of pesticides detected in samples collected in the Devonian-Silurian carbonate hydrogeologic setting of Pennsylvania, 2005.

[NWIS, National Water Information System; NWQL, U.S. Geological Survey National Water Quality Laboratory in Denver, Colo.; $\mu \mathrm{g} / \mathrm{L}$, micrograms per liter; MDL, method detection limit; MRL, minimum reporting level; $\mathrm{E}(1)$, estimated values reported for compound because the median long-term recovery in lab reagent spikes (LRS) is between 30 and 60 percent and (or) the F-pseudosigma of recoveries in LRS is greater than 25 percent; <, less than; $\geq$, greater than or equal to]

\begin{tabular}{lccccc}
\hline & \multicolumn{5}{c}{ Compound } \\
\cline { 2 - 5 } & Atrazine & CIAT', E(1) & Metolachlor & Acetochlor & Simazine \\
\hline NWIS parameter code & 39632 & 04040 & 39415 & 49260 & 04035 \\
Lab used & NWQL & NWQL & NWQL & NWQL & NWQL \\
Number of wells sampled & 28 & 28 & 28 & 28 & 28 \\
MDL, in $\mu \mathrm{g} / \mathrm{L}$ & 0.004 & 0.003 & 0.003 & 0.003 & 0.002 \\
MRL, in $\mu \mathrm{g} / \mathrm{L}$ & .007 & .006 & .006 & .006 & .005 \\
Number of samples having concentrations & 13 & 13 & & & 27 \\
$\quad<$ MRL & 1 & 0 & 0 & 0 & 0 \\
$\quad$ Estimated $<$ MRL & 1 & 1 & 1 & 0 & 1 \\
$\quad$ MRL to $<0.01 \mu \mathrm{g} / \mathrm{L}$ & 13 & 14 & 0 & 1 & 2 \\
$\quad \geq 0.01 \mu \mathrm{g} / \mathrm{L}$ & & & 27 & 25 \\
\hline
\end{tabular}

${ }^{1}$ Degradation product: CIAT, 2-chloro-4-isopropylamino-6-amino-s-triazine or deethylatrazine (NWIS parameter code 04040). 


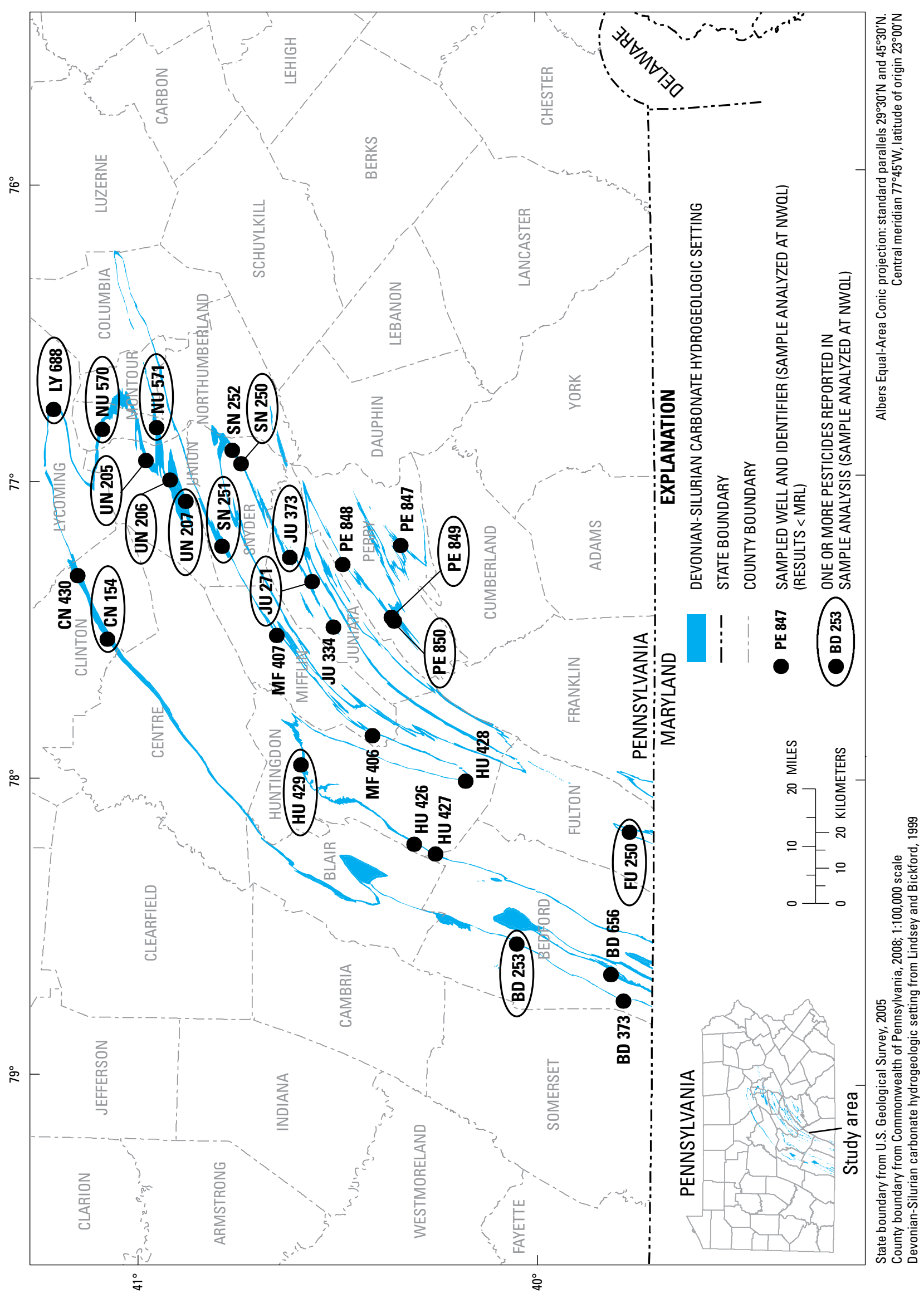

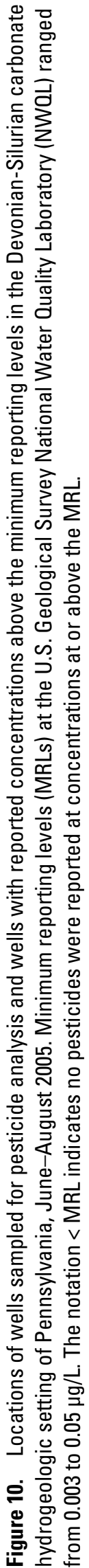


Table 15. Local well numbers and concentrations of pesticides in samples collected in the Devonian-Silurian carbonate hydrogeologic setting of Pennsylvania, 2005.

[All pesticide results are from analyses completed at the U.S. Geological Survey National Water Quality Laboratory in Denver, Colo.; samples for these wells were collected in June-August 2005; all concentrations reported are in bold font; if concentration reported is estimated, a notation is located under the reported value; $\mathrm{E}(1)$, estimated value because the median long-term recovery in lab reagent spikes (LRS) is between 30 and 60 percent and (or) the F-pseudosigma of recoveries in LRS is greater than 25 percent; $\mathrm{E}(2)$, estimated value because the concentration is greater than or equal to the long-term method detection limit but less than the minimum reporting level; $\mu \mathrm{g} / \mathrm{L}$, micrograms per liter; MRL, minimum reporting level; -, concentration less than the MRL but not estimated; $<$, less than; NWIS, National Water Information System]

\begin{tabular}{|c|c|c|c|c|c|}
\hline \multirow{2}{*}{$\begin{array}{l}\text { Local } \\
\text { well no. }\end{array}$} & \multicolumn{5}{|c|}{ Concentration, in $\mu \mathrm{g} / \mathrm{L}$} \\
\hline & Atrazine & CIAT ${ }^{1}$ & Metolachlor & Acetochlor & Simazine \\
\hline MRL & $<0.007$ & $<0.006$ & $<0.006$ & $<0.006$ & $<0.005$ \\
\hline BD 253 & .036 & $\begin{array}{l}. \mathbf{0 3 5} \\
\mathrm{E}(1)\end{array}$ & - & - & - \\
\hline HU 429 & .052 & $\begin{array}{l}.062 \\
\mathrm{E}(1)\end{array}$ & - & - & - \\
\hline FU 250 & .008 & $\begin{array}{l}.014 \\
\mathrm{E}(1)\end{array}$ & - & - & - \\
\hline PE 850 & .017 & $\begin{array}{l}. \mathbf{0 1 4} \\
\mathrm{E}(1)\end{array}$ & - & - & - \\
\hline PE 849 & .023 & $\begin{array}{l}.056 \\
\mathrm{E}(1)\end{array}$ & - & - & .013 \\
\hline $\mathrm{CN} 154$ & .016 & $\begin{array}{l}. \mathbf{0 2 1} \\
\mathrm{E}(1)\end{array}$ & - & - & - \\
\hline SN 251 & .024 & $\begin{array}{l}. \mathbf{0 1 5} \\
\mathrm{E}(1)\end{array}$ & - & - & .008 \\
\hline JU 373 & $\begin{array}{l}.004 \\
\mathrm{E}(2)\end{array}$ & $\begin{array}{l}.013 \\
\mathrm{E}(1)\end{array}$ & - & - & - \\
\hline JU 271 & - & - & - & .029 & - \\
\hline SN 250 & .027 & $\begin{array}{l}. \mathbf{0 3 3} \\
\mathrm{E}(1)\end{array}$ & - & - & - \\
\hline UN 207 & .045 & $\begin{array}{l}.019 \\
\mathrm{E}^{(1)}\end{array}$ & - & - & - \\
\hline UN 206 & .052 & $\begin{array}{l}.052 \\
\mathrm{E}(1)\end{array}$ & - & - & - \\
\hline NU 571 & .014 & $\begin{array}{l}.032 \\
\mathrm{E}(1)\end{array}$ & - & - & - \\
\hline UN 205 & .054 & $\begin{array}{l}.009 \\
\mathrm{E}(1)\end{array}$ & .008 & - & - \\
\hline NU 570 & .032 & $\begin{array}{l}.034 \\
\mathrm{E}(1)\end{array}$ & - & - & .010 \\
\hline LY 688 & .048 & $\begin{array}{l}. \mathbf{0 6 1} \\
\mathrm{E}(1)\end{array}$ & - & - & - \\
\hline
\end{tabular}

${ }^{1}$ Degradation product: CIAT, 2-chloro-4-isopropylamino-6-amino-s-triazine or deethylatrazine (NWIS parameter code 04040). 


\section{Great Valley Siliciclastic}

Thirty rural domestic wells were sampled in the Great Valley siliciclastic setting from June through August 2006. The samples were analyzed for 52 pesticides at the USGS NWQL. For the Great Valley siliciclastic setting, the numbers of samples with pesticide detections are shown in table 16. In this setting, only concentrations of atrazine, CIAT, and simazine were above the MRL (table 17). Simazine was reported at $0.007 \mu \mathrm{g} / \mathrm{L}$ in one sample. Three well-water samples had trace amounts of atrazine under the MRL (less than $0.007 \mu \mathrm{g} / \mathrm{L}$ ), and two samples had concentrations above $0.01 \mu \mathrm{g} / \mathrm{L}$ (table 16). CIAT also was detected in three samples below the MRL (less than $0.014 \mu \mathrm{g} / \mathrm{L}$ ) and in one sample above $0.01 \mu \mathrm{g} / \mathrm{L}$. Both napronamide and metolachlor were reported at concentrations less than the respective MRLs. Locations of wells sampled and wells with concentrations of pesticides reported above and below the MRLs are shown in figure 11 .

Five well-water samples had reported concentrations of pesticides (table 17). Four of the five wells showed co-occurrence of atrazine and CIAT, and two of these wells had water that included either napropamide or metolachlor and simazine. Maximum concentrations of atrazine and CIAT in the samples collected in the Great Valley siliciclastic setting were 0.025 and E $0.033 \mu \mathrm{g} / \mathrm{L}$, respectively - both in one sample collected at well NP 828. The sample from this well also had the maximum combined concentration of all pesticides (as mass per volume $[\mu \mathrm{g} / \mathrm{L}]$ and not normalized to moles per volume) $-0.068 \mu \mathrm{g} / \mathrm{L}$. Median recoveries in LRS samples for CIAT were low in 2006 ( 35 percent); therefore, the concentration of CIAT in well NP 828 may actually be greater than that reported.

Table 16. Number of samples with no pesticides detected below the minimum reporting levels and with concentrations of pesticides detected in samples collected in the Great Valley siliciclastic hydrogeologic setting of Pennsylvania, 2006.

[NWIS, National Water Information System; NWQL, U.S. Geological Survey National Water Quality Laboratory in Denver, Colo.; $\mu \mathrm{g} / \mathrm{L}$, micrograms per liter; MDL, method detection limit; MRL, minimum reporting level; $\mathrm{E}(1)$, estimated values reported for compound because the median long-term recovery in lab reagent spikes (LRS) is between 30 and 60 percent and (or) the F-pseudosigma of recoveries in LRS is greater than 25 percent; -, range not applicable; $<$, less than; $\geq$, greater than or equal to]

\begin{tabular}{lccccc}
\hline & \multicolumn{5}{c}{ Compound } \\
\cline { 2 - 6 } & Atrazine & CIAT', E(1) & Metolachlor & Napronamide & Simazine \\
\hline NWIS parameter code & 39632 & 04040 & 39415 & 82684 & 04035 \\
Lab used & NWQL & NWQL & NWQL & NWQL & NWQL \\
Number of wells sampled & 30 & 30 & 30 & 30 & 30 \\
MDL, in $\mu \mathrm{g} / \mathrm{L}$ & 0.004 & 0.007 & 0.003 & 0.003 & 0.002 \\
MRL, in $\mu \mathrm{g} / \mathrm{L}$ & .007 & .014 & .006 & .007 & .005 \\
Number of samples having concentrations & 25 & 26 & & & 29 \\
$\quad<$ MRL & 3 & 3 & 28 & 1 & 0 \\
$\quad$ Estimated $<$ MRL & 0 & - & 0 & 0 & 1 \\
$\quad \geq$ MRL to $<0.01 \mu \mathrm{g} / \mathrm{L}$ & 2 & 1 & 0 & 0 & 0 \\
$\quad \geq 0.01 \mu \mathrm{g} / \mathrm{L}$ & & & 29 & & \\
\hline
\end{tabular}

${ }^{1}$ Degradation product: CIAT, 2-chloro-4-isopropylamino-6-amino-s-triazine or deethylatrazine (NWIS parameter code 04040). 
Table 17. Local well numbers and concentrations of pesticides in samples collected in the Great Valley siliciclastic hydrogeologic setting of Pennsylvania, 2006.

[All pesticide results are from analyses completed at the U.S. Geological Survey National Water Quality Laboratory in Denver, Colo.; samples for these wells were collected from June through August 2006; all concentrations reported are in bold font; if concentration reported is estimated, a notation is located under the reported value; E(1), estimated value because the median long-term recovery in lab reagent spikes (LRS) is between 30 and 60 percent and (or) the F-pseudosigma of recoveries in LRS is greater than 25 percent; E(2), estimated value because the concentration is greater than or equal to the long-term method detection limit but less than the minimum reporting level; E(3), estimated because the value is below the long-term method detection limit; MRL, minimum reporting level; -, concentration less than the MRL but not estimated; <, less than; NWIS, National Water Information System]

\begin{tabular}{|c|c|c|c|c|c|}
\hline \multirow{2}{*}{$\begin{array}{l}\text { Local } \\
\text { well no. }\end{array}$} & \multicolumn{5}{|c|}{ Concentration, in micrograms per liter } \\
\hline & Atrazine & CIAT' & Metolachlor & Napronamide & Simazine \\
\hline MRL & $<0.007$ & $<0.014$ & $<0.006$ & $<0.007$ & $<0.005$ \\
\hline LE 1428 & $\begin{array}{l}. \mathbf{0 0 3} \\
\mathrm{E}(3)\end{array}$ & $\begin{array}{l}.002 \\
\mathrm{E}(1), \mathrm{E}(3)\end{array}$ & - & $\begin{array}{l}.004 \\
\mathrm{E}(2)\end{array}$ & - \\
\hline NP 828 & .025 & $\begin{array}{l}. \mathbf{0 3 3} \\
\mathrm{E}(1)\end{array}$ & $\begin{array}{l}. \mathbf{0 0 3} \\
\mathrm{E}(2)\end{array}$ & - & .007 \\
\hline NP 826 & $\begin{array}{l}.002 \\
\text { E(3) }\end{array}$ & - & $\begin{array}{l}.001 \\
\mathrm{E}(3)\end{array}$ & - & - \\
\hline NP 827 & .012 & $\begin{array}{l}. \mathbf{0 0 8} \\
\mathrm{E}(1), \mathrm{E}(2)\end{array}$ & - & - & - \\
\hline NP 818 & $\begin{array}{l}.002 \\
\mathrm{E}(3)\end{array}$ & $\begin{array}{l}.002 \\
\mathrm{E}(1), \mathrm{E}(3)\end{array}$ & - & - & - \\
\hline
\end{tabular}

${ }^{1}$ Degradation product: CIAT, 2-chloro-4-isopropylamino-6-amino-s-triazine or deethylatrazine (NWIS parameter code 04040). 


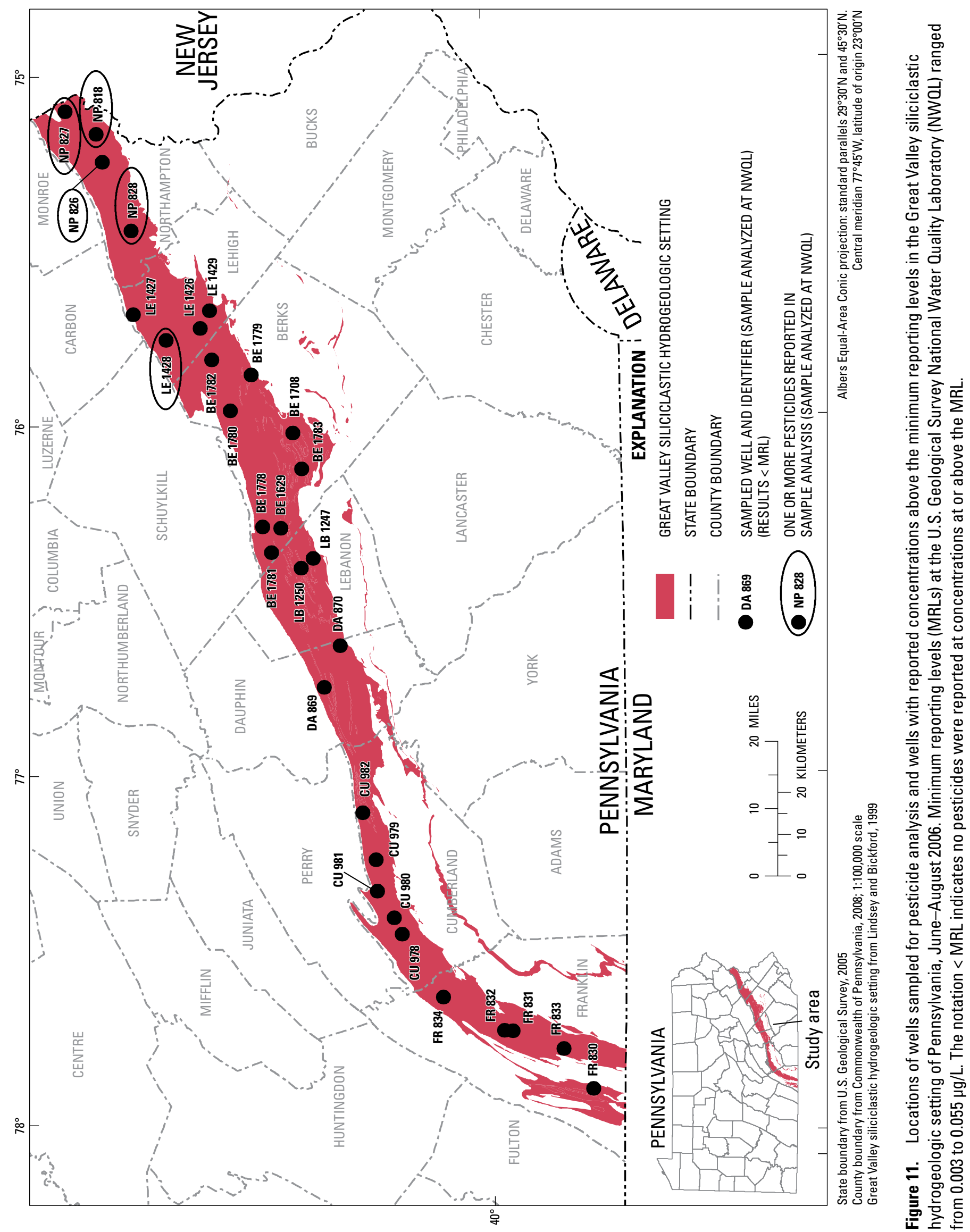




\section{Northeastern Glaciated Surficial}

Twenty-eight wells were sampled in the Northeastern Glaciated surficial setting from May through September 2007. Of these wells, 7 were used for public-water supply, 3 were used for commercial supply, 1 was used for fire-protection supply, and 17 were used for rural domestic supply. The samples were analyzed for 52 pesticides at the USGS NWQL. The numbers of samples with pesticide detections are shown in table 18. In this setting, seven samples had concentrations above the MRL for atrazine, and three samples had concentrations above the MRL for CIAT. The remainder of the concentrations reported for atrazine, CIAT, metolachlor, and simazine were estimated values less than the MRL. Locations of wells sampled and wells with concentrations of pesticides reported above and below the MRLs are shown in figure 12 .

Sixteen of the 28 well-water samples had reported concentrations of pesticides (table 19). Three wells (LY 691,
LY 692, and WY 196) had estimated concentrations of only one pesticide-CIAT. Thirteen samples had co-occurrence of atrazine and CIAT; 5 of these samples also had concentrations of metolachlor and (or) simazine (table 19). Five of seven samples from production wells had co-occurrence of two or more pesticides; however, concentrations were $0.012 \mu \mathrm{g} / \mathrm{L}$ or less.

Maximum concentrations of atrazine and CIAT in the Northeastern Glaciated surficial setting were $0.064 \mu \mathrm{g} / \mathrm{L}$ (well LY 690) and E $0.025 \mu \mathrm{g} / \mathrm{L}$ (well BR 884), respectively (table 19). The sum of concentrations of all pesticides from these two wells were similar (as mass per volume $[\mu \mathrm{g} / \mathrm{L}]$ and not normalized to moles per volume) $-0.089 \mu \mathrm{g} / \mathrm{L}$ for well BR 884 and $0.085 \mu \mathrm{g} / \mathrm{L}$ for well LY 690 . Combined reported concentrations for all other wells were $0.030 \mu \mathrm{g} / \mathrm{L}$ or less.

Table 18. Numbers of samples with no pesticides detected below the minimum reporting levels and with concentrations of pesticides detected in samples collected in the Northeastern Glaciated surficial hydrogeologic setting of Pennsylvania, 2007.

[NWIS, National Water Information System; NWQL, U.S. Geological Survey National Water Quality Laboratory in Denver, Colo.; samples for these wells were collected from May through September 2007; E(1), estimated values reported for compound because the median long-term recovery in lab reagent spikes (LRS) is between 30 and 60 percent and (or) the F-pseudosigma of recoveries in LRS is greater than 25 percent; $\mu \mathrm{g} / \mathrm{L}$, micrograms per liter; MDL, method detection limit; MRL, minimum reporting level; -, range not applicable; $<$, less than; $\geq$, greater than or equal to]

\begin{tabular}{lcccc}
\hline & \multicolumn{4}{c}{ Compound } \\
\cline { 2 - 5 } & Atrazine & CIAT', E11) & Metolachlor & Simazine \\
\hline NWIS parameter code & 39632 & 04040 & 39415 & 04035 \\
Lab used & NWQL & NWQL & NWQL & NWQL \\
Number of wells sampled & 28 & 28 & 28 & 28 \\
MDL, in $\mu \mathrm{g} / \mathrm{L}$ & 0.004 & 0.007 & 0.005 & 0.003 \\
MRL, in $\mu \mathrm{g} / \mathrm{L}$ & .007 & .014 & .01 & .006 \\
Number of samples having concentrations & & & & \\
$\quad<$ MRL & 15 & 12 & 25 & 25 \\
$\quad$ Estimated $<$ MRL & 6 & 13 & 3 & 0 \\
$\quad$ MRL to $<0.01 \mu \mathrm{g} / \mathrm{L}$ & 3 & - & - & 0 \\
$\quad \geq 0.01 \mu \mathrm{g} / \mathrm{L}$ & 4 & 3 & 0 & 0 \\
\hline
\end{tabular}

${ }^{1}$ Degradation product: CIAT, 2-chloro-4-isopropylamino-6-amino-s-triazine or deethylatrazine (NWIS parameter code 04040). 


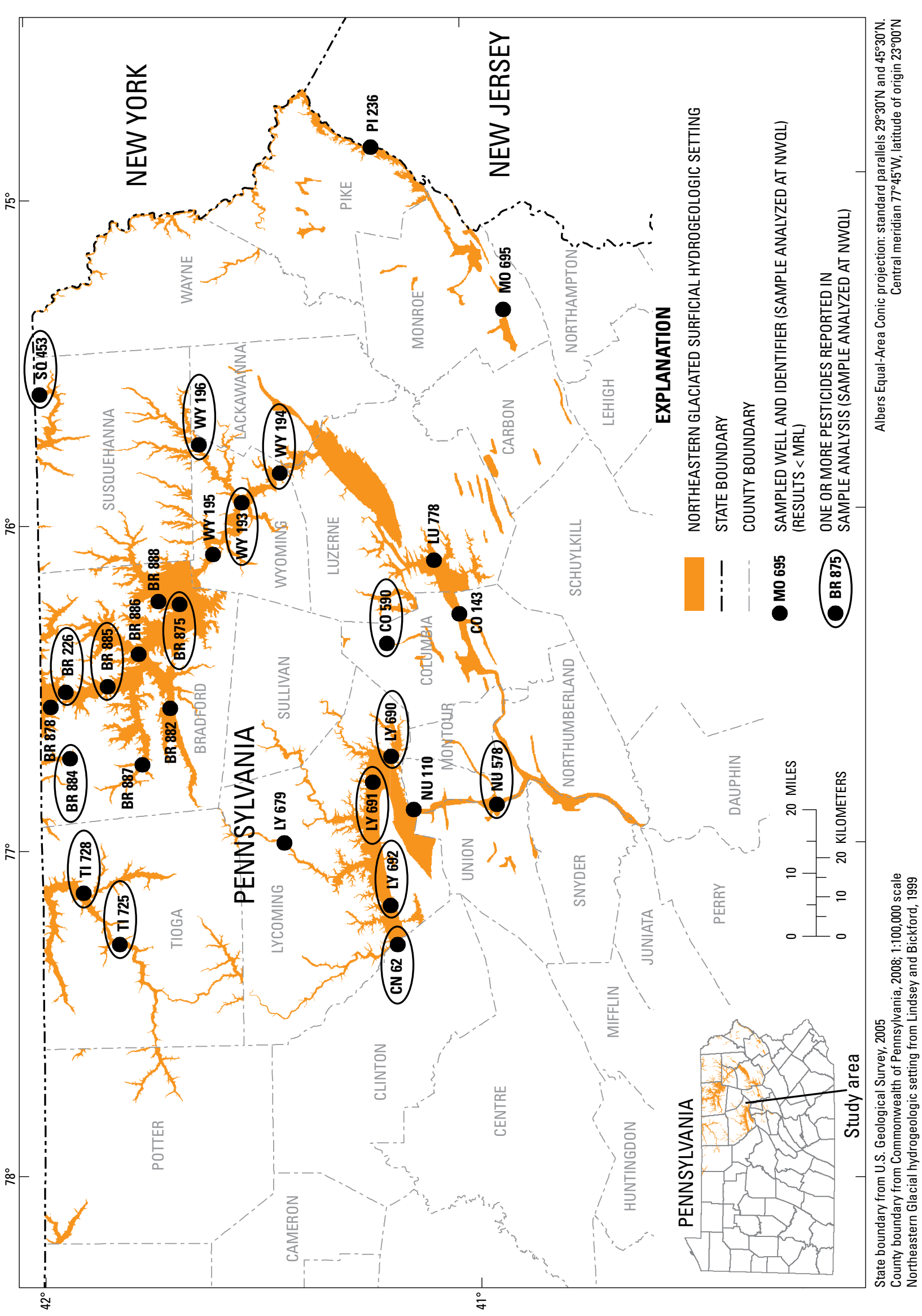

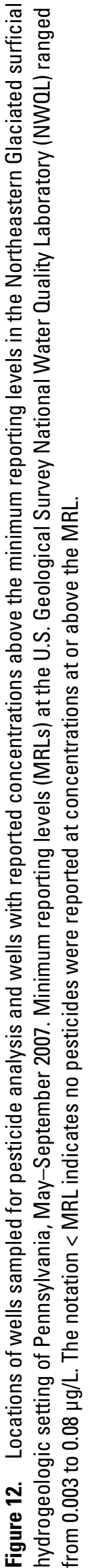


Table 19. Local well numbers and concentrations of pesticides in samples collected in the Northeastern Glaciated surficial hydrogeologic setting of Pennsylvania, 2007.

[All pesticide results are from analyses completed at the U.S. Geological Survey National Water Quality Laboratory in Denver, Colo.; samples for these wells were collected from May through September 2007; all concentrations reported are in bold font; if concentration reported is estimated, a notation is located under the reported value; E(1), estimated value because the median longterm recovery in lab reagent spikes (LRS) is between 30 and 60 percent and (or) the F-pseudosigma of recoveries in LRS is greater than 25 percent; $\mathrm{E}(2)$, estimated value because the concentration is greater than or equal to the long-term method detection limit but less than the minimum reporting level; E(3), estimated because the value is below the long-term method detection limit; MRL, minimum reporting level; -, concentration less than the MRL but not estimated; <, less than; NWIS, National Water Information System]

\begin{tabular}{|c|c|c|c|c|}
\hline \multirow{2}{*}{$\begin{array}{c}\text { Local } \\
\text { well no. }\end{array}$} & \multicolumn{4}{|c|}{ Concentration, in micrograms per liter } \\
\hline & Atrazine & CIAT $^{1}$ & Metolachlor & Simazine \\
\hline MRL & $<0.007$ & $<0.014$ & $<0.010$ & $<0.006$ \\
\hline \multirow[t]{2}{*}{${ }^{2} \mathrm{CN} 62$} & .007 & .004 & .003 & - \\
\hline & & $\mathrm{E}(1), \mathrm{E}(3)$ & $\mathrm{E}(3)$ & \\
\hline \multirow[t]{2}{*}{ LY 692} & - & .003 & - & - \\
\hline & & $\mathrm{E}(1), \mathrm{E}(3)$ & & \\
\hline \multirow[t]{2}{*}{ TI 725} & .004 & .002 & - & - \\
\hline & $\mathrm{E}(2)$ & $\mathrm{E}(1), \mathrm{E}(3)$ & & \\
\hline \multirow[t]{2}{*}{${ }^{2} \mathrm{TI} 728$} & .002 & .002 & - & .004 \\
\hline & $\mathrm{E}(3)$ & $\mathrm{E}(1), \mathrm{E}(3)$ & & $\mathrm{E}(2)$ \\
\hline \multirow[t]{2}{*}{ BR 884} & .061 & .025 & .003 & - \\
\hline & & $\mathrm{E}(1)$ & $\mathrm{E}(3)$ & \\
\hline \multirow[t]{2}{*}{ LY 691} & - & .006 & - & - \\
\hline & & $E(1), E(3)$ & & \\
\hline \multirow[t]{2}{*}{ LY 690} & .064 & .021 & - & - \\
\hline & & $\mathrm{E}(1)$ & & \\
\hline \multirow[t]{2}{*}{${ }^{2} \mathrm{NU} 578$} & .002 & .008 & - & - \\
\hline & $\mathrm{E}(3)$ & $\mathrm{E}(1), \mathrm{E}(2)$ & & \\
\hline \multirow[t]{2}{*}{ CO 590} & .008 & .006 & - & .002 \\
\hline & & $\mathrm{E}(1), \mathrm{E}(3)$ & & $\mathrm{E}(3)$ \\
\hline \multirow[t]{2}{*}{${ }^{2} \mathrm{BR} 885$} & .012 & .008 & - & - \\
\hline & & $E(1), E(2)$ & & \\
\hline \multirow[t]{2}{*}{${ }^{2} \mathrm{BR} 226$} & .008 & .005 & .002 & .002 \\
\hline & & $E(1), E(3)$ & $\mathrm{E}(3)$ & E(3) \\
\hline \multirow[t]{2}{*}{ BR 875} & .004 & .011 & & \\
\hline & $\mathrm{E}(2)$ & $E(1), E(2)$ & & \\
\hline \multirow[t]{2}{*}{ WY 194} & .010 & .020 & - & - \\
\hline & & $\mathrm{E}(1)$ & & \\
\hline \multirow[t]{2}{*}{ WY 193} & .003 & .013 & - & - \\
\hline & $\mathrm{E}(3)$ & $E(1), E(2)$ & & \\
\hline \multirow[t]{2}{*}{ WY 196} & - & .002 & - & - \\
\hline & & $\mathrm{E}(1), \mathrm{E}(3)$ & & \\
\hline \multirow[t]{2}{*}{ SQ 453} & .004 & .003 & - & - \\
\hline & $\mathrm{E}(2)$ & $\mathrm{E}(1), \mathrm{E}(3)$ & & \\
\hline
\end{tabular}

${ }^{1}$ Degradation product: CIAT, 2-chloro-4-isopropylamino-6-amino-s-triazine or deethylatrazine (NWIS parameter code 04040).

${ }^{2}$ Production well. 


\section{Correlating Pesticide Occurrence with Other Indicators of Water-Quality Degradation}

Statistical analysis was used to investigate the strength of the relations among pesticide occurrence and two indicators of water-quality degradation —occurrence of bacteria and nitrate concentration.

To test the relation between pesticide and bacteria occurrence, a $2 \times 2$ contingency-table analysis was used to determine associations between the two nominal categorical variables (Helsel and Hirsch, 2002, p. 378). For this analysis, the categorical variables were the presence/absence of total coliform bacteria and the presence/absence of the pesticides atrazine or metolachlor above the MRLs in analyses of ground water by the USGS NWQL. In order for the standard chisquare test to be valid, each of the four categories of the contingency table must have an expected number of observations greater than one and at least 80 percent of the categories must have an expected number of observations greater than five (Helsel and Hirsch, 2002). These criteria were not met; hence, the Fisher's exact test (Uitenbroek, 1997) was used because the probability (p) value is accurate for all sample sizes. A significance level of 0.05 was used (p less than or equal to 0.05 ).

The results of the contingency-table analysis (fig. 13) indicated a significant relation between the presence or absence of atrazine or metolachlor and the presence or absence of bacteria in the Blue Ridge crystalline and Triassic Lowland siliciclastic setting $(p=0.0333)$. Relations for the DevonianSilurian carbonate, Great Valley siliciclastic, or Northeastern Glaciated surficial settings were not significant $(\mathrm{p}>0.05)$. The Eastern Lake surficial setting was excluded from testing because none of the 20 samples from the setting were analyzed for atrazine and metolachlor at the USGS NWQL.

To evaluate if there was a linear association between 1) number of pesticides above the MRLs and nitrate concentration, and 2) atrazine concentration and nitrate concentration (figs. 14 and 15, respectively), Spearman's rank correlation was used. Spearman's rank method can be used when both variables have a substantial number of non-detected values
(Helsel and Hirsch, 2002) and involves ranking each variable separately and then calculating the Spearman's rank correlation coefficient for the ranks (Ott, 1993); all non-detected values are assigned the lowest rank value. Alpha levels and Spearman's rho statistics from the Spearman's rank correlation indicate the statistical significance of the association and the strength of the association, respectively. For this analysis, an alpha of 0.05 was used, and, therefore, if the probability generated from the Spearman's correlation is less than 0.05, there is a 95-percent chance that a mathematical association is present between the variables. Spearman's rho values can range from zero to one; the closer the Spearman's rho is to a value of one, the greater the strength of the association. The rank correlation used data from the Devonian-Silurian carbonate, Great Valley siliciclastic, and Northeastern Glaciated surficial settings with SAS software (SAS Institute, 1990). Data from samples collected in the Eastern Lake surficial and Blue Ridge crystalline and Triassic Lowland siliciclastic settings were not analyzed because all or part of the samples were analyzed at the PADEPL where MRLs were greater than USGS NWQL MRLs. The greatest atrazine MRL used for collective work done in the Blue Ridge crystalline and Triassic Lowland siliciclastic setting was $0.10 \mu \mathrm{g} / \mathrm{L}$ where 10 samples were analyzed at the PADEPL (MRL for atrazine was $<0.10 \mu \mathrm{g} / \mathrm{L}$; a suite of 18 pesticides analyzed) and 10 samples were analyzed at the NWQL (MRL for atrazine was $<0.007 \mu \mathrm{g} / \mathrm{L}$; a suite of 115 pesticides analyzed).

Results of the Spearman's rank correlation showed strong correlations between the number of pesticides above the MRLs and nitrate concentration ( $r$ ho $=0.85$ and $p<0.0001$ ) and between concentrations of atrazine and nitrate $(\mathrm{rho}=0.88$ and $\mathrm{p}<0.0001)$ in the Devonian-Silurian carbonate setting. The relation between concentrations of atrazine and nitrate in the Great Valley siliciclastic setting was statistically significant (rho $=0.53$ and $p=0.0025)$. There were no statistically significant relations in the Great Valley siliciclastic $(\mathrm{rho}=0.35$ and $\mathrm{p}=0.0597)$ or Northeastern Glaciated surficial $(\mathrm{rho}=0.06$ and $p=0.7672$ ) hydrogeologic settings between number of pesticides above the MRLs and nitrate concentration or in the Northeastern Glaciated surficial setting between concentrations of atrazine and nitrate ( $r h o=0.19$ and $\mathrm{p}=0.3358)$. 


\begin{tabular}{|c|c|c|}
\hline \multicolumn{3}{|c|}{$\begin{array}{c}\text { Blue Ridge crystalline and Triassic Lowland } \\
\text { siliciclastic hydrogeologic setting, 2003 }\end{array}$} \\
\hline \multirow{2}{*}{$\mathbf{N}=\mathbf{1 0}$} & \multicolumn{2}{|c|}{$\begin{array}{c}\text { One-sided p-value for } \\
\text { (Observed } \geq \text { Expected) = } \mathbf{0 . 0 3 3 3}\end{array}$} \\
\cline { 2 - 3 } & $\begin{array}{c}\text { Number of samples } \\
\text { with TC bacteria } \\
\text { present }\end{array}$ & $\begin{array}{c}\text { Number of samples } \\
\text { with TC bacteria } \\
\text { absent }\end{array}$ \\
\hline $\begin{array}{c}\text { Number of samples } \\
\text { with Atrz or } \\
\text { Metol present } \\
\text { above the MRLs }\end{array}$ & 3 & \\
\hline $\begin{array}{c}\text { Number of samples } \\
\text { with Atrz or } \\
\text { Metol absent } \\
\text { above the MRLs }\end{array}$ & 1 & \\
\hline \multicolumn{2}{|c|}{} \\
\hline
\end{tabular}

\begin{tabular}{|c|c|c|}
\hline \multirow{2}{*}{ Devonian-Silurian carbonate hydrogeologic setting, 2005 } \\
\hline \multirow{2}{*}{$\mathbf{N}=\mathbf{2 7}$} & $\begin{array}{c}\text { One-sided p-value for } \\
\text { p (Observed } \geq \text { Expected) = } \mathbf{0 . 2 9 2 8}\end{array}$ \\
\cline { 2 - 3 } & $\begin{array}{c}\text { Number of samples } \\
\text { with TC bacteria } \\
\text { present }\end{array}$ & $\begin{array}{c}\text { Number of samples } \\
\text { with TC bacteria } \\
\text { absent }\end{array}$ \\
\hline $\begin{array}{c}\text { Number of samples } \\
\text { with Atrz or } \\
\text { Metol present } \\
\text { above the MRLs }\end{array}$ & 11 & \\
\hline $\begin{array}{c}\text { Number of samples } \\
\text { with Atrz or } \\
\text { Metol absent } \\
\text { above the MRLs }\end{array}$ & 8 & \\
\hline \multicolumn{2}{|c|}{} & \\
\hline
\end{tabular}

\begin{tabular}{|c|c|c|}
\hline \multicolumn{2}{|c|}{ Great Valley siliciclastic hydrogeologic setting, 2006} \\
\hline \multirow{N}{*}{$=\mathbf{3 0}$} & $\begin{array}{c}\text { One-sided p-value for } \\
\mathbf{p} \text { (Observed } \geq \text { Expected) = } \mathbf{0 . 6 4 8 3}\end{array}$ \\
\cline { 2 - 3 } & $\begin{array}{c}\text { Number of samples } \\
\text { with TC bacteria } \\
\text { present }\end{array}$ & $\begin{array}{c}\text { Number of samples } \\
\text { with TC bacteria } \\
\text { absent }\end{array}$ \\
\hline $\begin{array}{c}\text { Number of samples } \\
\text { with Atrz or } \\
\text { Metol present } \\
\text { above the MRLs }\end{array}$ & 1 & \\
\hline $\begin{array}{c}\text { Number of samples } \\
\text { with Atrz or } \\
\text { Metol absent } \\
\text { above the MRLs }\end{array}$ & 11 & \\
\hline
\end{tabular}

\begin{tabular}{|c|c|c|}
\hline \multicolumn{2}{|c|}{ Northeastern Glaciated surficial hydrogeologic setting, 2007 } \\
\hline $\mathbf{N}=\mathbf{2 8}$ & \multicolumn{2}{|c|}{$\begin{array}{r}\text { One-sided p-value for } \\
\text { p (Observed } \geq \text { Expected) = 0.8077 }\end{array}$} \\
\cline { 2 - 3 } & $\begin{array}{c}\text { Number of samples } \\
\text { with TC bacteria } \\
\text { present }\end{array}$ & $\begin{array}{c}\text { Number of samples } \\
\text { with TC bacteria } \\
\text { absent }\end{array}$ \\
\hline $\begin{array}{c}\text { Number of samples } \\
\text { with Atrz or } \\
\text { Metol present } \\
\text { above the MRLs }\end{array}$ & 3 & \\
\hline $\begin{array}{c}\text { Number of samples } \\
\text { with Atrz or } \\
\text { Metol absent } \\
\text { above the MRLs }\end{array}$ & 11 & \\
\hline
\end{tabular}

\section{EXPLANATION}

TC, Total Coliform; Atrz, Atrazine; Metol, Metolachlor; MRL, minimum reporting level; $\mathrm{N}$, number of samples.

p-value is the test statistic, and a p-value of 0.05 or less is significant at the 95 percent confidence level.

Atrazine MRL is less than 0.007 micrograms per liter

Metolachlor MRL is less than 0.006 to 0.013 micrograms per liter

Figure 13. Contingency table $(2 \times 2)$ and one-sided $p$-values resulting from Fischer's Exact Test for the same or stronger associations (Uitenbroek, 1997) from four hydrogeologic settings, Pennsylvania, 2003 and 2005-07, to determine relation of presence or absence of pesticides (by use of occurrence of atrazine or metolachlor in ground-water samples at or above the minimum reporting level concentrations as measured by the USGS National Water Quality Laboratory) and presence or absence of total coliform bacteria in ground-water samples. 


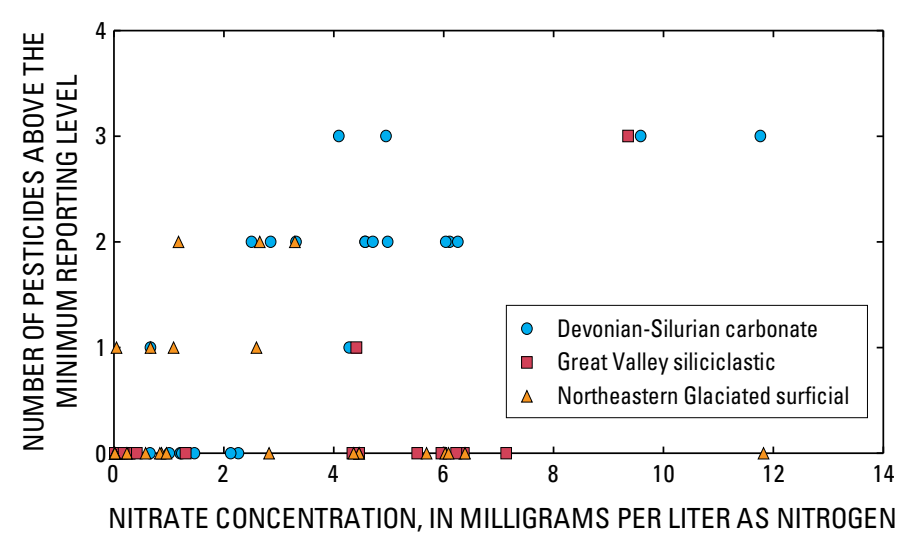

Figure 14. The relation between numbers of pesticides above the minimum reporting level and nitrate concentration in wellwater samples collected in the Devonian-Silurian carbonate, Great Valley siliciclastic, and Northeastern Glaciated surficial hydrogeologic settings of Pennsylvania. Pesticide analyses for these settings were completed at the U.S. Geological Survey (USGS) National Water Quality Laboratory (NWQL). Data from the Eastern Lake surficial and Blue Ridge crystalline and Triassic Lowland siliciclastic settings are not shown because all or part of the samples were analyzed at the Pennsylvania Department of Environmental Protection Laboratory where minimum reporting levels (MRLs) were greater than MRLs at the USGS NWQL.

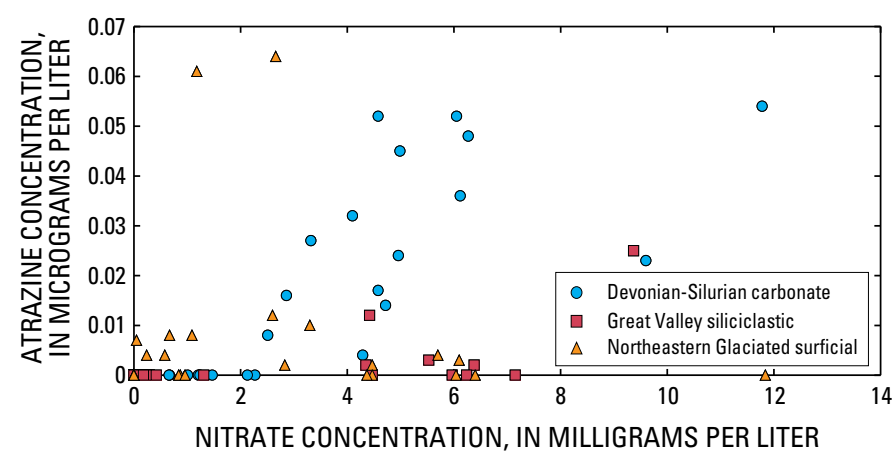

Figure 15. The relation between concentrations of atrazine and nitrate in well-water samples collected in the Devonian-Silurian carbonate, Great Valley siliciclastic, and Northeastern Glaciated surficial hydrogeologic settings of Pennsylvania. Pesticide analyses for these settings were completed at the U.S. Geological Survey (USGS) National Water Quality Laboratory (NWQL). Data from the Eastern Lake surficial and Blue Ridge crystalline and Triassic Lowland siliciclastic settings are not shown because all or part of the samples were analyzed at the Pennsylvania Department of Environmental Protection Laboratory where minimum reporting levels (MRLs) were greater than MRLs at the USGS NWOL.

\section{Trend Assessments}

\section{Pesticide Concentration Changes for Selected Wells in Baseline-Assessment Areas}

Several wells have been sampled in Pennsylvania as part of this project and as part of the National Water-Quality Assessment (NAWQA) Program (Delaware, Lower Susquehanna, and Potomac River Basins) to assess ground-water quality and how it is changing over time (fig. 16). Wells selected for a trend network in baseline-assessment areas to evaluate long-term changes in pesticide concentration were previously sampled for USGS (Lower Susquehanna or Delaware NAWQA programs), PDA, or Pennsylvania Department of Environmental Protection programs (table 20). Sixteen wells initially were chosen for inclusion in this network because available data from 1993 to 2001 indicated measureable concentrations of one or more pesticides in ground water. Water from these wells had one or more concentrations of pesticides above an arbitrary value of $0.20 \mu \mathrm{g} / \mathrm{L}$. A minimum concentration of $0.20 \mu \mathrm{g} / \mathrm{L}$ was chosen to evaluate change from initial concentrations reported in the 1993 to 2001 samples. Because of difficulties locating wells with reported historical concentrations of pesticides in the Triassic Lowland siliciclastic setting, well AD 1184 was located through a referral; previous concentrations of pesticides for a sample collected by Groundwater Sciences Corporation in February 1997 were stored in the Agway Andgrow (East Berlin, Pa.) Chemistry Database and were available from the well owner. In 2004, one replacement well had to be located in each of the Great Valley carbonate and Piedmont carbonate settings. Of the 18 wells (appendix 3), 4 wells were in each of the Appalachian Mountain carbonate and Triassic Lowland siliciclastic settings, and 5 wells were in each of the Great Valley carbonate and Piedmont carbonate settings (fig. 16) (table 20). These four settings were ranked 'high' or 'moderate/high' in relative vulnerability to pesticide contamination (Lindsey and Bickford, 1999). Pesticide samples were analyzed at the USGS NWQL in 2003, and the PADEPL was used for pesticide analyses in 2004.

Most of the well-water samples collected from 1993 to 2001 were analyzed either at the NWQL (GCMS methodology) or the PADEPL (USEPA 525.2, GCMS methodology). There were two exceptions - water for well LN 1763 was analyzed at the PDA laboratory in 1995 using an immunoassay method, and water for well AD 1184 was analyzed at EnviroTest Laboratories, Inc. using the USEPA 608 wastewater method (gas chromatography [GC]).

The wells selected for a trend network in baseline-assessement areas originally were sampled for programs with their own respective timelines for sample collection. For the majority of wells sampled, the initial sample was collected during the post-emergent pesticide-application period (June-August) (table 20). Fifteen of the selected wells were resampled in 


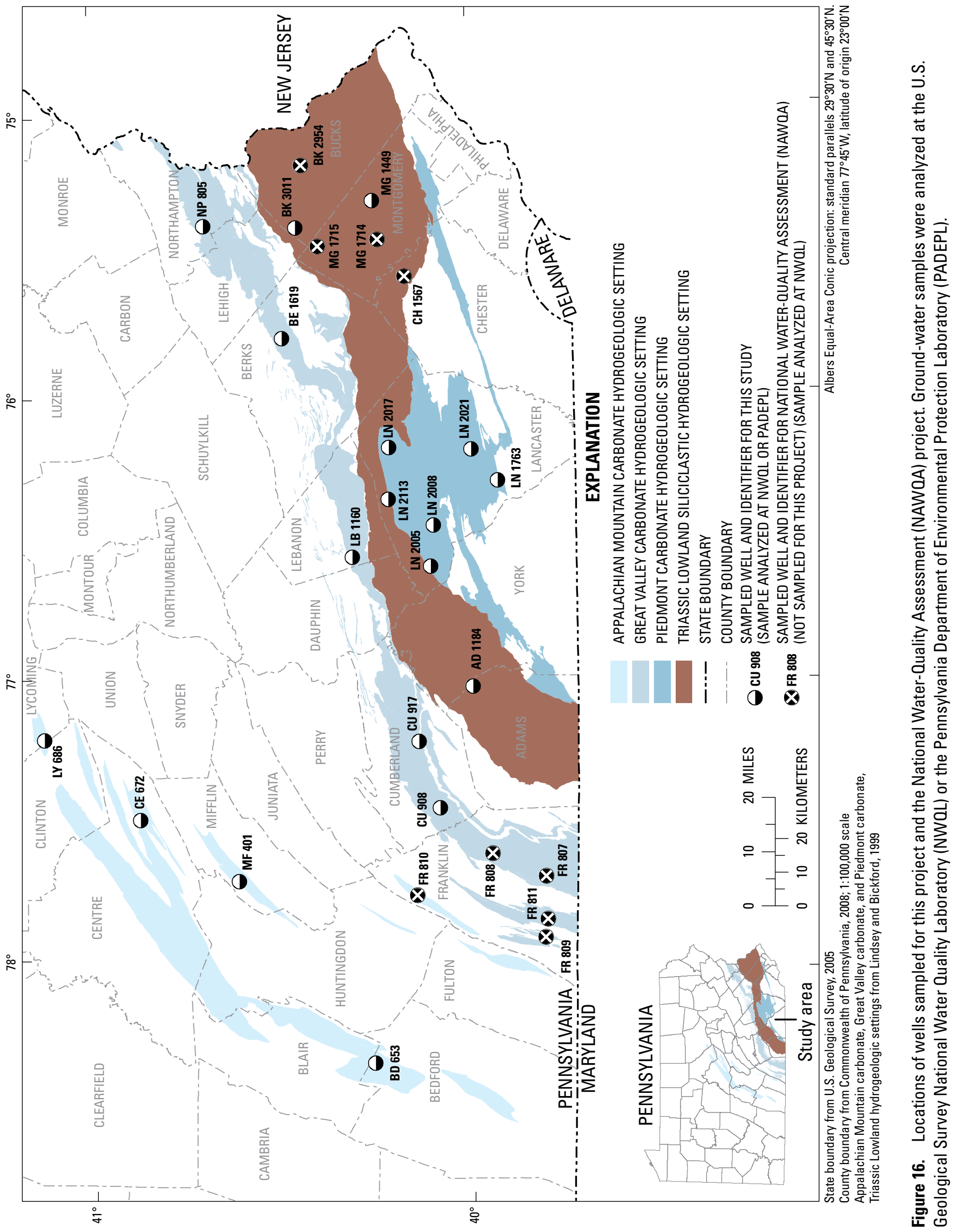


量

宕苛

需

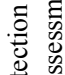

要

焉

产

氙㺃

零

㯊

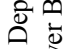

学

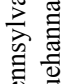

気 胥

i क

贸高

安

苋管

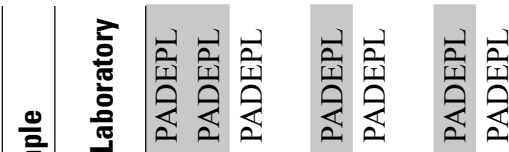

氙

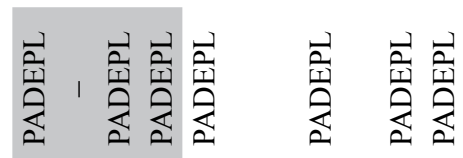

స్.

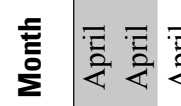

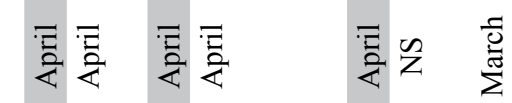

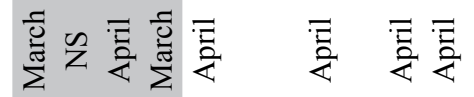

을

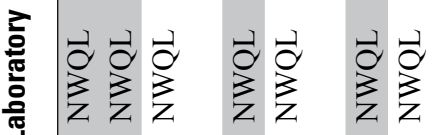

$\begin{array}{ll}\vec{\partial} \partial & \partial \\ z & z\end{array}$

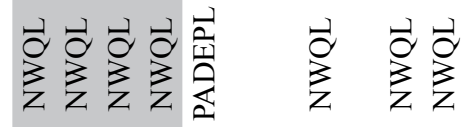

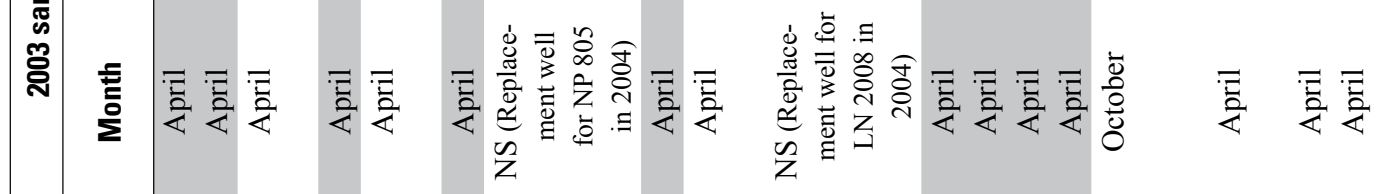

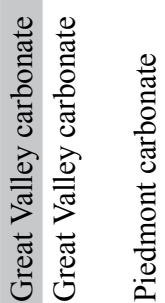

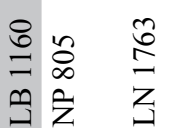
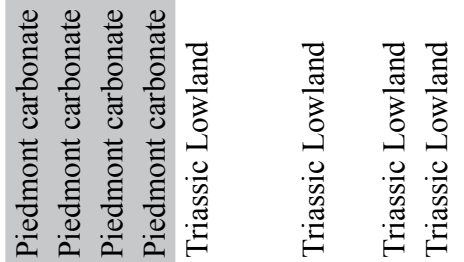
April 2003, and these samples were analyzed at the NWQL for 52 pesticides with MRLs ranging from 0.002 to $0.05 \mu \mathrm{g} / \mathrm{L}$; well AD 1184 was resampled in October 2003, and this sample was analyzed at the PADEPL for 10 pesticides with MRLs ranging from 0.10 to $0.12 \mu \mathrm{g} / \mathrm{L}$. The following year (2004), samples were collected March 30-April 29 and analyzed for 10 pesticides at the PADEPL with MRLs of 0.10 to $0.25 \mu \mathrm{g} / \mathrm{L}$.

Nine of the wells chosen as trend wells in baselineassessment areas were used to determine changes in long-term pesticide concentrations. The nine wells were selected because the NWQL was the analyzing laboratory for one-time samples collected in 1993, 1994, or 1995 as part of the NAWQA project in Pennsylvania and again for samples collected as part of this project (2003). Pesticides reported in the initial sample (1993, 1994, or 1995) generally were still present in samples collected in 2003; however, the concentrations generally were lower than in the previous samples. Changes in concentration from 1993 to 2003 are shown by well, using atrazine and its breakdown product CIAT as examples, in figure 17. Water-level changes in the wells ranging from 2.5 to nearly $40 \mathrm{ft}$ (fig. 17) indicate high water levels in 2003 compared to 1993-95 could be a factor in the concentration changes observed. Water-level rises attributed to recharge could dilute the concentration of pesticides in ground water or could carry pesticides to ground water thereby increasing the concentrations. If breakdown processes alone were responsible for the drop in atrazine concentration, a systematic increase in CIAT concentration might be expected; however, this was not observed. Hence, water-level change is one factor that, along with land-use change and pesticide-use change, needs to be considered in explaining the lower concentrations in 2003 compared to 1993-95.

Nonparametric statistical analyses were used to determine long-term changes in pesticide concentrations at the nine trend wells in baseline-assessment areas. The Kruskal-Wallis test is a rank-transform test used as a screening tool to examine for significant differences in the medians of two or more groups of data (Helsel and Hirsch, 2002). In this study, concentrations of atrazine and metolachlor in samples from the nine wells sampled one time in 1993, 1994, or 1995 and one time again in 2003 were ranked from lowest to highest; all censored data (values less than the reporting limits) were assigned the lowest rank. The test compared the rank-transformed pesticide data to the categorical variable sample date (group 1-pesticide data 1993, 1994, or 1995; group 2 - pesticide data 2003). If results of the Kruskal-Wallis test showed statistically significant differences in the ranked concentrations grouped by sample date at a significance level of 0.05 , the Tukey-Kramer multiplecomparison test was used to determine which groups differed from each other. The groups with the highest medians were assigned a letter " $A$," the groups with the next highest medians were assigned a letter "B," or an "AB" combination, and so on. Any groups assigned the same letter (or combination of letters) designations were not statistically different from each other.
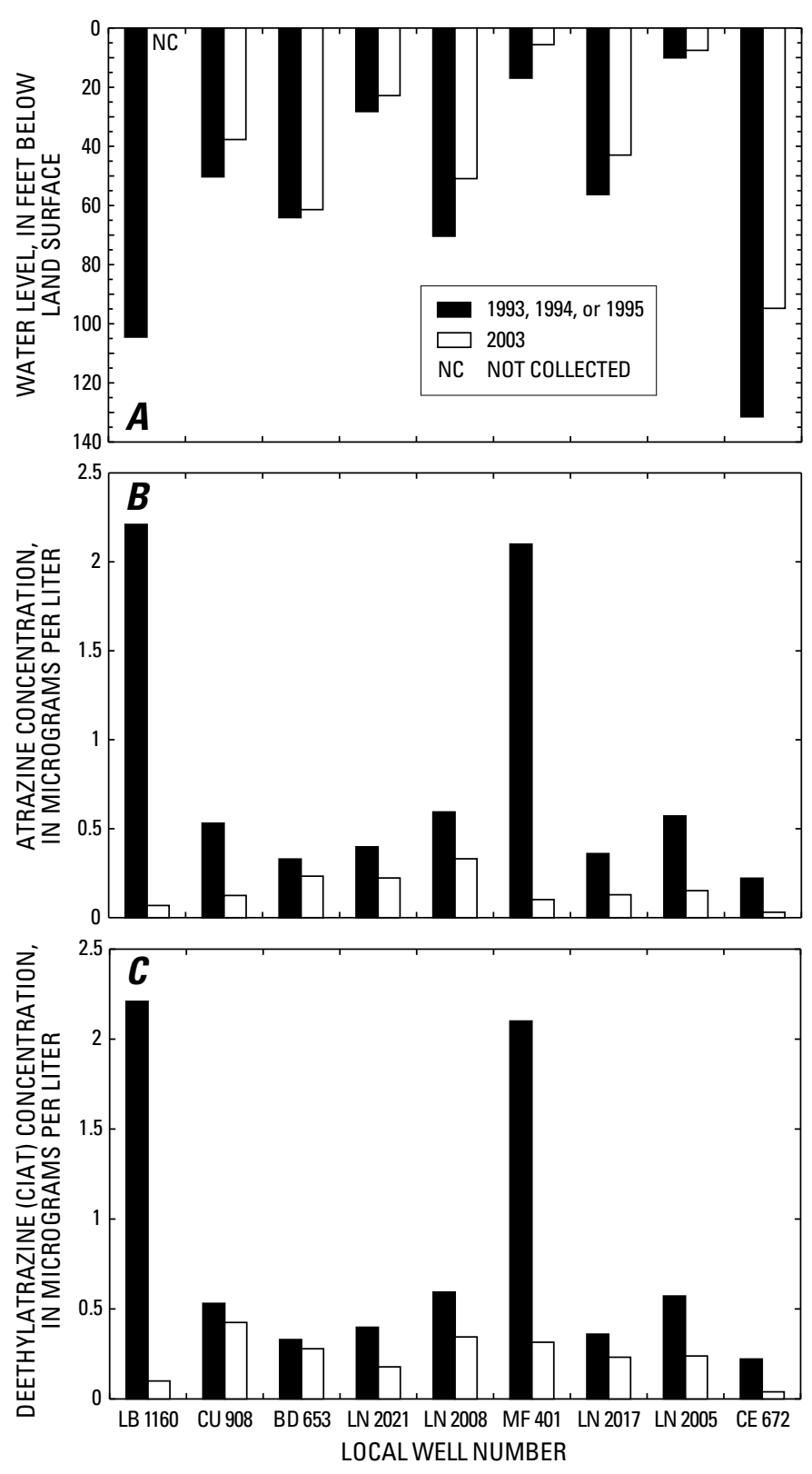

Figure 17. Data for nine wells in agricultural row-crop settings underlain by carbonate bedrock, Lower Susquehanna River Basin, Pennsylvania, from a one-time sample from those wells in 1993-95 and a sample in 2003 for $A$ ) water level, $B$ ) concentration of atrazine, and $C$ ) concentration of CIAT (deethylatrazine), a breakdown product of atrazine. 
Using the Kruskal-Wallis and Tukey-Kramer multiplecomparison tests, significantly lower median concentrations of atrazine were observed in the samples collected from the nine trend wells in baseline-assessment areas during 2003 than during 1993-95 (fig. 18a). No significant change was observed in median concentrations of metolachlor between sample dates.

Because of the availability of paired observations from the nine trend wells in baseline-assessment areas, the Wilcoxon signed-rank test (Helsel and Hirsch, 2002) was used to test for temporal changes in median concentrations at a 0.05 significance level. Censored pesticide concentrations (values below the reporting limit, or non-detects) were assigned a common value lower than the lowest quantified pesticide concentration. Therefore, all values below the reporting limit for a single pesticide compound were tied at the lowest rank.
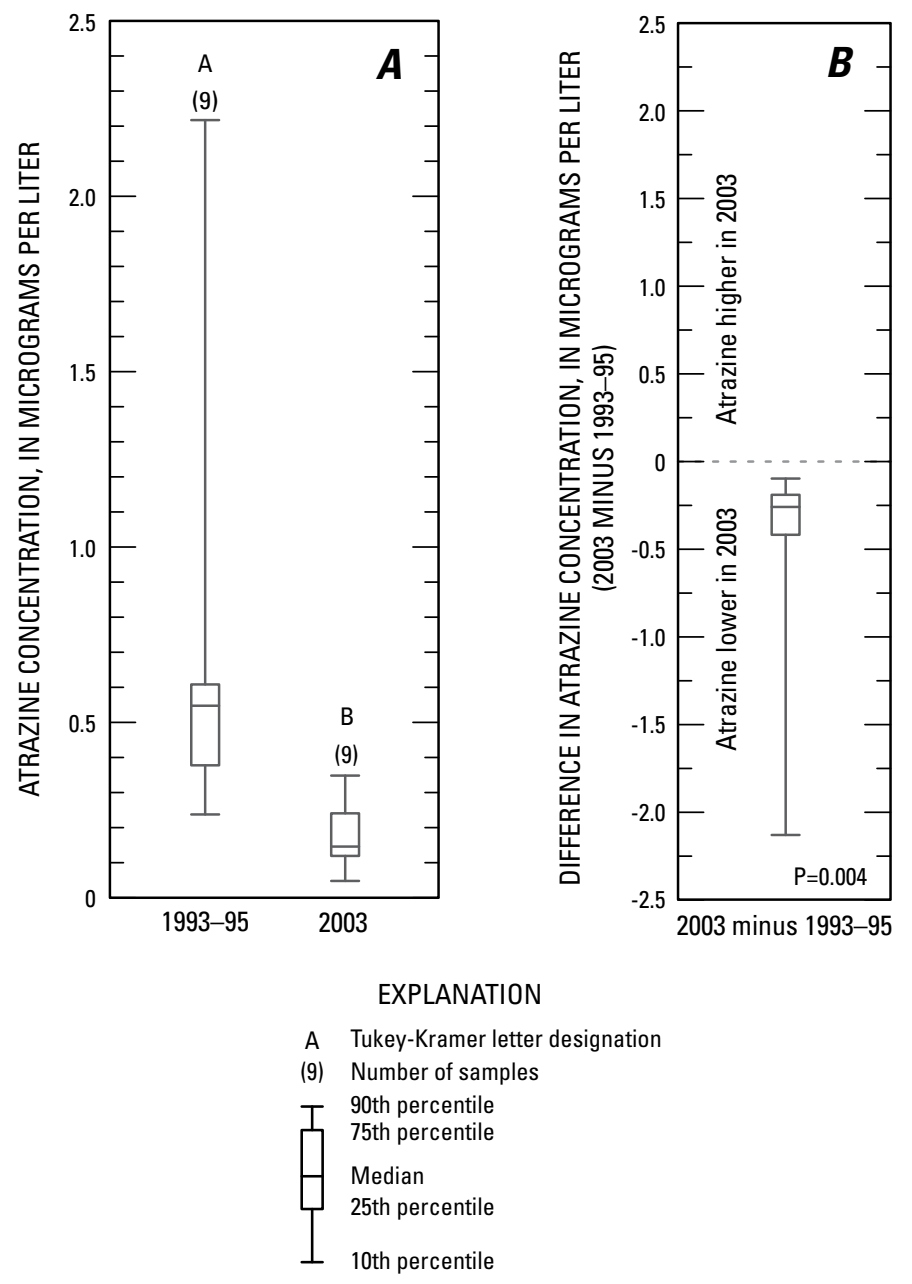

Figure 18. Range of $A$ ) atrazine concentrations 1993-95 (onetime sample) compared to 2003 with results of Tukey-Kramer multiple-comparison test and $B$ ) paired differences in atrazine concentrations 2003 minus 1993-95 for nine wells in agricultural row-crop setting underlain by carbonate bedrock, Lower Susquehanna River Basin, Pennsylvania. P-value indicates result of the Wilcoxon signed-rank test.
Pesticide concentrations from the nine sites sampled once in 2003 were subtracted from the pesticide concentrations from each of the same wells in 1993, 1994, or 1995. Examining these differences in paired-observation data, a significant decrease in atrazine concentration was identified $(p=0.004$, fig. 18b). The pattern of decline in atrazine concentrations for this study is consistent with results of other ground-water studies. For example, Kolpin and others (1997) reported decreasing concentrations of atrazine in ground-water samples collected from selected municipal wells in Iowa over time (1982-95). Conversely, Kolpin and others (1997) reported increasing concentrations of metolachlor in the Iowa wells over that same time period (1982-95). The decreasing trend for atrazine and the increasing trend for metolachlor were reported to be consistent with changes in statewide chemical use and application rates for the two pesticides; there were no apparent relations between precipitation and temporal patterns in atrazine and metolachlor (Kolpin and others, 1997). A study of ground-water quality in agricultural areas of the Mid-Atlantic region (Potomac NAWQA), including carbonate rocks in the Great Valley, reported significantly decreasing concentrations of atrazine, CIAT, and prometon in $2002 \mathrm{com}-$ pared to 1993 (Debrewer and others, 2008). The decreasing trend in pesticide concentrations was reported by Debrewer and others (2008) to be related to hydrogeology, climate, changes in land use, and changes in chemical applications. As explained previously, water-level change, land-use change, pesticide-use change, and date of sample collection are all factors for this study that need to be considered in explaining the lower atrazine concentrations in 2003 compared to 1993-95. From 1993-95 to 2003, the amount of land used for row-crop agriculture decreased (table 1), atrazine pesticide application (fig. 5) decreased in many counties in Pennsylvania over the past 10 years, and water levels increased (fig. 17). Similar findings for metolachlor were not observed for this study. Applications of metolachlor/S-metolachlor increased from 1996 to 2004-05 in many counties (fig. 6), but the Wilcoxon signed-rank test did not identify a significant temporal change in concentrations for the nine trend wells in baseline-assessment areas $(\mathrm{p}=0.625)$.

Because the 2003 data showed that pesticide concentrations had dropped below the action levels set for the PDA PPGWS (appendix 4) and that further sample collection would only serve to confirm the trend to low concentrations with a large added cost to the project, the collection of samples at these baseline-assessment-area wells was discontinued before the field season in 2005 .

\section{Pesticide and Nitrate Concentration Changes for Three Hot-Spot Wells in Areas of Special Ground-Water Protection}

The three hot-spot wells in areas of special ground-water protection are in the Great Valley carbonate, Appalachian Mountain carbonate, and Piedmont carbonate hydrogeologic 
settings (fig. 7), areas known for high percentages of land in row crop and high pesticide usage (Lindsey and Bickford, 1999). These areas are also known to have high concentrations of nitrate in ground water (Lindsey and others, 1997). The wells frequently had one or more pesticide concentrations at or above the PPGWS action levels (invoked by the PDA at fractions of the USEPA MCLs or Lifetime Health Advisories [LHAs], appendix 4) prior to when this project began in 2003.

The Berks County hot-spot well (BE 1370) is on a farm in the Great Valley carbonate setting. The initial sample collected in 1998 from this well had an alachlor concentration of $14 \mu \mathrm{g} / \mathrm{L}$, which was above the USEPA MCL of $2 \mu \mathrm{g} / \mathrm{L}$. Thus, hot-spot monitoring was initiated in 1998. Water from well BE 1370 historically had nitrate concentrations one to two times the USEPA MCL of $10 \mathrm{mg} / \mathrm{L}$ as N (nitrogen) (U.S. Environmental Protection Agency, 2008).

The Blair County hot-spot well (BA 437), in the Appalachian Mountain carbonate setting, is at a building housing municipal offices and the highway department. The building is in an agricultural area and is adjacent to a property historically used for pesticide mixing and handling. When the first sample was collected in 1984, concentrations of atrazine and alachlor were 11 and $20 \mu \mathrm{g} / \mathrm{L}$, respectively. The nitrate concentration of $100 \mathrm{mg} / \mathrm{L}$ as $\mathrm{N}$ was 10 times the USEPA MCL of $10 \mathrm{mg} / \mathrm{L}$ as N. From 2003 to 2006, four samples collected at well BA 437 exceeded the PPGWS action level for metolachlor prior to the USEPA LHA change from 100 to $700 \mu \mathrm{g} / \mathrm{L}$ in 2006, and one sample (August 2003) exceeded the PPGWS action level for atrazine $(1.0 \mu \mathrm{g} / \mathrm{L})$.

The Lancaster County hot-spot well (LN 1842) is on a farm in the Piedmont carbonate setting. The barnyard area near the well is also used for handling and mixing of pesticides. When the first sample was collected in 1991, the well water had reported concentrations for atrazine and alachlor of 1.8 and $2.8 \mu \mathrm{g} / \mathrm{L}$, respectively. With the exception of the August 2007 sample, all samples collected at well LN 1842 from 2003 to 2007 exceeded the PPGWS action level of $0.66 \mu \mathrm{g} / \mathrm{L}$ for alachlor. Samples collected between 1996 and 2005 frequently had reported concentrations of metolachlor near to or above the 2004 USEPA LHA $(100 \mu \mathrm{g} / \mathrm{L})$ (U.S. Environmental Protection Agency, 2004). The USEPA LHA was changed in 2006 to $700 \mu \mathrm{g} / \mathrm{L}$ (U.S. Environmental Protection Agency, 2006); no sample concentrations exceeded the 2006 USEPA LHA for metolachlor between 2006 and 2007. Nitrate concentrations have historically been two to four times the USEPA MCL at this site.

Samples were collected seasonally at hot spots to examine pesticide concentrations in well water in the summer, fall, winter, and spring (appendix 3). The change from season to season usually results in predictable changes in water levels in wells. For example, water levels usually decline during summer and early fall months because of increased rates of evaporation and transpiration by plants; water levels usually rise in winter and early spring months because low rates of evaporation and transpiration allow recharge water to reach the aquifer. Timing for sampling was estimated by referencing on-line, real-time data (U.S. Geological Survey, 2008) for USGS wells in the county ground-water-level network (Lancaster, LN 1351; Berks, BE 623; and Blair, BA 74). Spring samples were collected from April through May, summer samples from June through early August, fall samples from late August through October, and winter samples from December through March. The timing of the fall sample collection was occasionally missed because of multiple major precipitation events that quickly changed water-level conditions before samples could be collected.

Evaluation of the hot-spot data to determine trends was done in two steps - exploratory data analysis and trend testing. For the exploratory data analysis, scatterplots were used to analyze the data graphically. LOWESS smooth curves derived by the data were added to the scatterplots, a smoothing technique that has no simple equation or significance test associated with it that is used to visually highlight patterns through the middle of the data (Helsel and Hirsch, 2002). Boxplots also were used to analyze the data graphically. After graphical analysis of the data, the Kruskal-Wallis test was used as a screening tool to examine for significant seasonality in the data sets for the hot-spot wells and the Tukey-Kramer multiple-comparison test was used to determine which seasonal groups differed from each other. Kruskal-Wallis and TukeyKramer tests can indicate whether or not seasonality may be an issue but do not account for trends in concentrations over time; therefore, if seasonality was observed with those tests, use of seasonal trend tests to analyze the data was warranted. For the trend testing, the Mann-Kendall and the Seasonal Kendall tests were used to analyze concentration data for temporal trends.

For hot-spot well BE 1370, historical alachlor concentrations were above the USEPA MCL of $2 \mu \mathrm{g} / \mathrm{L}$ until June 2001 (table 21); metolachlor and atrazine also were detected above the MRLs in the majority of samples collected from 1998 to 2007. Only one sample collected from 2003 to 2007 at hotspot well BE 1370 had an alachlor concentration that exceeded the PPGWS action level. When samples were analyzed at the NWQL (March and May 2003 and May 2005-May 2007), CIAT concentrations were greater than atrazine concentrations. Concentrations of alachlor, metolachlor, and atrazine in well water from BE 1370 decreased over time (fig. 19); the compounds with the largest initial concentrations (alachlor and metolachlor) showed the greatest decreases. During the periods of time when the NWQL was used for analytical work and CIAT was included in the analytical schedules, CIAT regularly co-occurred with reported concentrations of alachlor, metolachlor, and atrazine. CIAT concentrations also decreased over time.

For hot-spot well BA 437, alachlor, metolachlor, and atrazine had the greatest concentrations, but dieldrin, s-ethyl dipropylthiocarebamate (EPTC), prometon, CIAT, cyanazine, simazine, butylate, and carbofuran also had reported concentrations from 1996 to 2007 (table 22). Atrazine and alachlor showed slight decreases in concentration over time since the initial sample in 1996 (fig. 20). The concentration of 
Table 21. Pesticide co-occurrence in ground water collected at well BE 1370, Oley Township, Berks County, Pennsylvania, from 1998 to 2007. Concentrations of alachlor, metolachlor, and atrazine are shown in figure 19.

[All concentrations reported are in bold font; if concentration reported is estimated, a notation is located under the reported value; NWIS, National Water Informtion System; <, less than; E(1), estimated value because the median long-term recovery in lab reagent spikes (LRS) is between 30 and 60 percent and (or) the F-pseudosigma of recoveries in LRS is greater than 25 percent; E(2), estimated value because the concentration is greater than or equal to the long-term method detection limit but less than the minimum reporting level; E(3), estimated because the value is below the long-term method detection limit; na, not analyzed; nad, not analyzed because of sample damage at laboratory]

\section{Concentration, in micrograms per liter}

\begin{tabular}{|c|c|c|c|c|c|}
\hline $\begin{array}{c}\text { Sample } \\
\text { date }\end{array}$ & $\begin{array}{l}\text { 흘 } \\
\text { 링 } \\
\text { 잉 }\end{array}$ & $\begin{array}{l}\text { 흐 } \\
\frac{1}{e} \\
\frac{\pi}{\mathbb{2}}\end{array}$ & $\begin{array}{l}\frac{\text { 을 }}{\overline{0}} \\
\frac{\pi}{0} \\
\text { 일 }\end{array}$ & 尝 & $\frac{E}{0}$ \\
\hline
\end{tabular}

\begin{tabular}{|c|c|c|c|c|c|c|c|c|c|c|}
\hline $2 / 3 / 1998$ & na & 14 & 6.3 & 0.40 & na & na & $<0.30$ & na & $<0.30$ & na \\
\hline 4/7/1998 & na & 2.3 & 1.9 & .38 & na & na & $<.30$ & na & $<.30$ & na \\
\hline $1 / 26 / 1999$ & na & 9.4 & 4.5 & .45 & na & na & $<.10$ & na & $<.10$ & na \\
\hline $3 / 6 / 2000$ & na & 9.5 & 6.2 & .31 & na & na & $<.10$ & na & $<.10$ & na \\
\hline $2 / 7 / 2001$ & na & 2.2 & .76 & .20 & na & na & $<.10$ & na & $<.10$ & na \\
\hline $3 / 26 / 2003$ & $<0.006$ & .396 & 1.06 & .164 & $\begin{array}{c}\mathbf{0 . 3 1 8} \\
\mathrm{E}(1)\end{array}$ & $<0.006$ & na & $<0.015$ & $<.005$ & $\begin{array}{c}\mathbf{0 . 0 0 6} \\
\mathrm{E}(2)\end{array}$ \\
\hline $5 / 15 / 2003$ & $<.006$ & .260 & .461 & .154 & $\begin{array}{l}.234 \\
\mathrm{E}(1)\end{array}$ & $\begin{array}{l}.001 \\
\text { Е(3) }\end{array}$ & na & $\begin{array}{l}\mathbf{. 0 0 6} \\
\mathrm{E}(3)\end{array}$ & .006 & $\begin{array}{l}.003 \\
\mathrm{E}(3)\end{array}$ \\
\hline $4 / 19 / 2004$ & $<.10$ & $<.10$ & .22 & $<.10$ & na & na & $<.10$ & na & $<.10$ & na \\
\hline $7 / 21 / 2004$ & $<.10$ & .98 & 2.02 & .26 & na & na & $<.10$ & na & $<.10$ & na \\
\hline $10 / 6 / 2004$ & nad & nad & nad & nad & na & na & nad & na & nad & na \\
\hline $12 / 15 / 2004$ & $<.10$ & $<.10$ & .48 & .18 & na & na & $<.10$ & na & $<.10$ & na \\
\hline $5 / 24 / 2005$ & $<.006$ & .046 & .216 & .154 & $\begin{array}{l}.194 \\
\text { E(1) }\end{array}$ & $<.006$ & na & $<.010$ & $<.005$ & $<.009$ \\
\hline $5 / 30 / 2006$ & .015 & $<.005$ & .157 & .108 & .183 & $<.006$ & na & $<.010$ & $\begin{array}{l}.005 \\
\mathrm{E}(2)\end{array}$ & $<.009$ \\
\hline $5 / 17 / 2007$ & $<.006$ & .024 & .325 & .123 & $\begin{array}{l}.157 \\
\mathrm{E}(1) \\
\end{array}$ & $<.002$ & na & $<.008$ & $<.006$ & $\begin{array}{l}.002 \\
\mathrm{E}(3) \\
\end{array}$ \\
\hline
\end{tabular}

${ }^{1}$ Degradation product: CIAT, 2-chloro-4-isopropylamino-6-amino-s-triazine or deethylatrazine (NWIS parameter code 04040). 


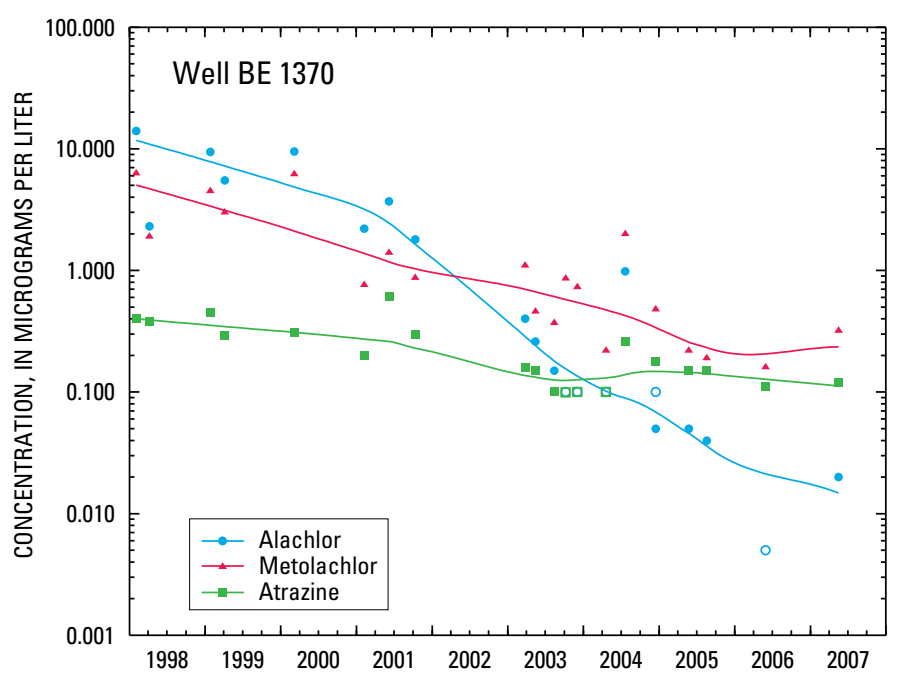

Figure 19. Concentrations of alachlor, metolachlor, and atrazine in samples collected from 1998 to 2007 at well BE 1370, Oley Township, Berks County, Pennsylvania. Lines fitted through the data are LOWESS smooth curves. Concentrations less than minimum reporting levels (MRLs) were plotted as open symbols at concentrations equal to the respective MRLs (these concentrations were included in the formulation of LOWESS smooth curves).

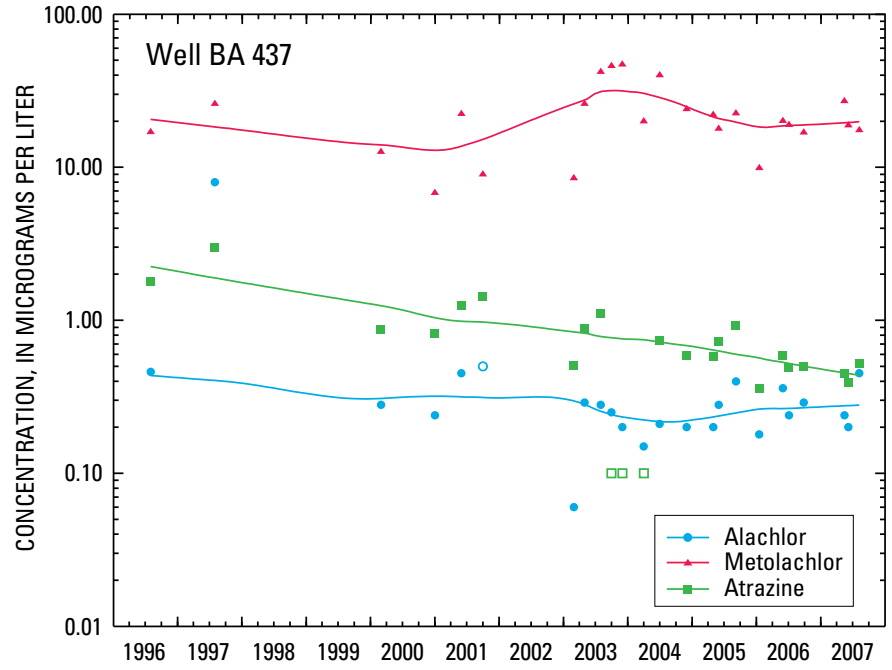

Figure 20. Concentrations of alachlor, metolachlor, and atrazine in samples collected from 1996 to 2007 at well BA 437, North Woodbury Township, Blair County, Pennsylvania. Lines fitted through the data are LOWESS smooth curves. Concentrations less than minimum reporting levels (MRLs) were plotted as open symbols at concentrations equal to the respective MRLs (these concentrations were included in the formulation of LOWESS smooth curves). 


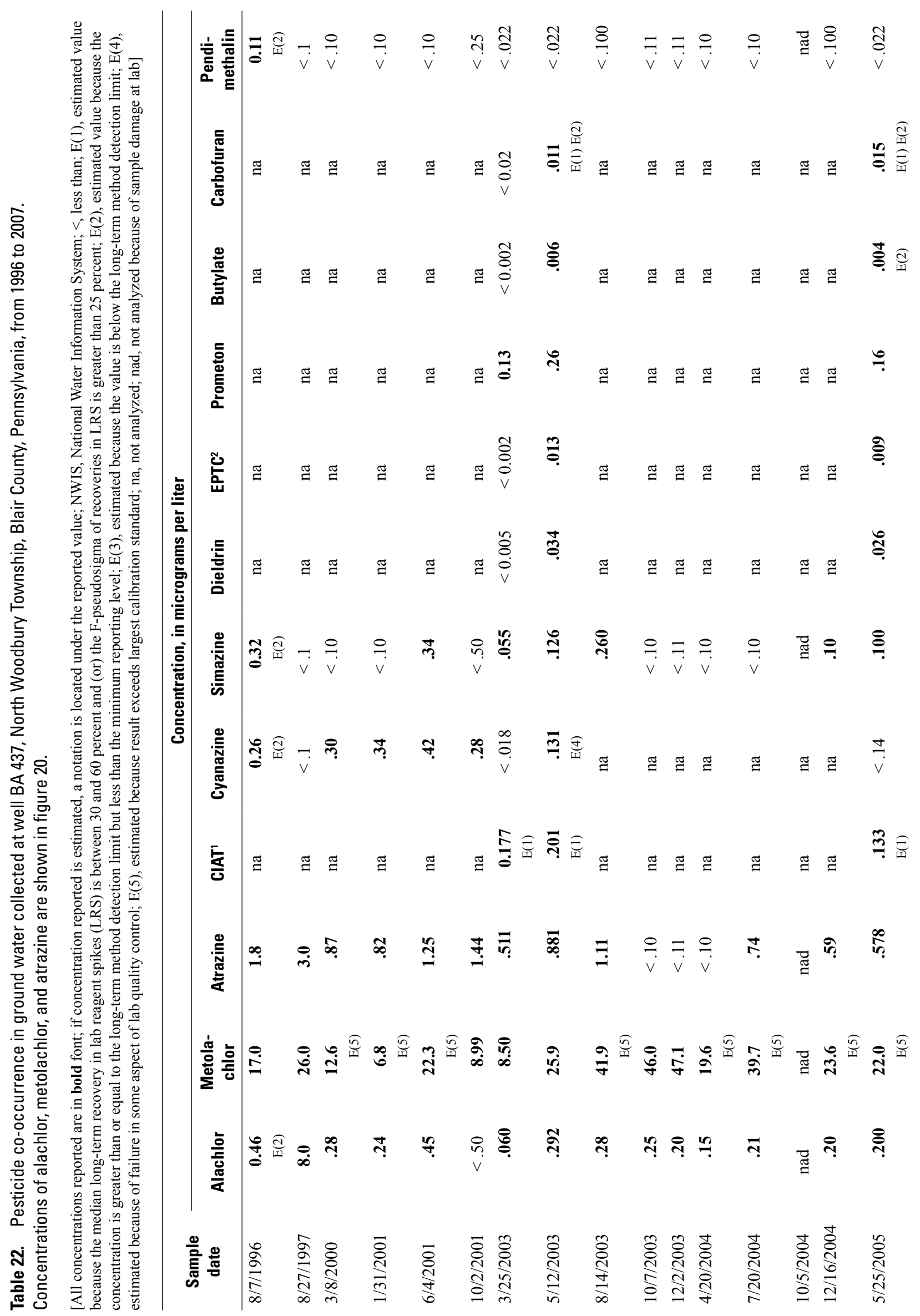




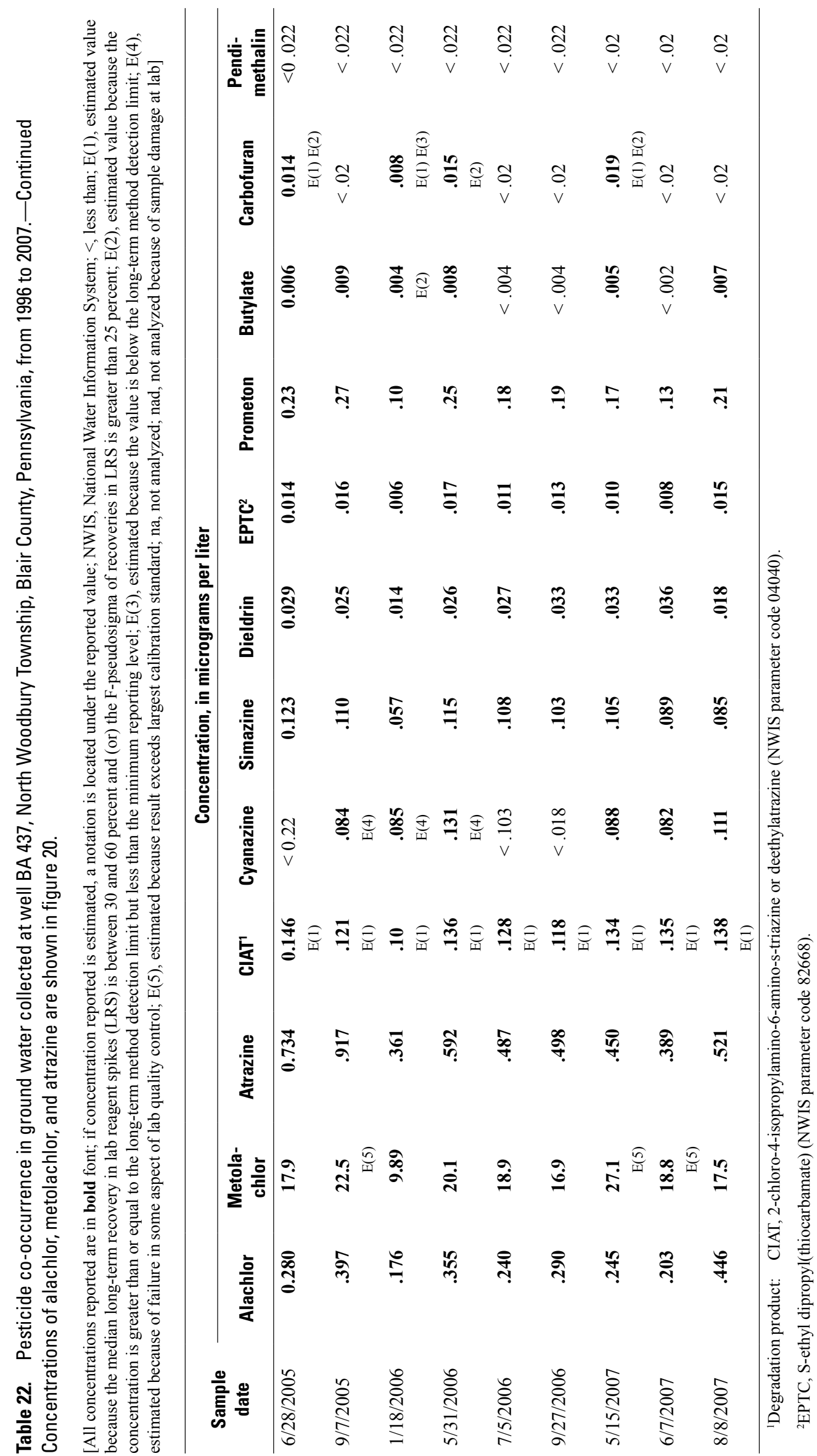


metolachlor ranged from 6.8 to $47.1 \mu \mathrm{g} / \mathrm{L}$ from 1996 to 2007 (table 22) with periods of decreasing and increasing concentration resulting in little overall change (fig. 20). Concentrations of cyanazine, simazine, and the atrazine degradate CIAT have slight but generally steady declines over their respective periods of record; the concentrations of dieldrin, EPTC, butylate, carbofuran, and prometon remained fairly constant (table 22).

For hot-spot well LN 1842, reported concentrations of acetochlor, alachlor, metolachlor, and atrazine from 1995 to 2007 are shown in figure 21. CIAT, cyanazine, simazine, butylate, EPTC, linuron, napropamide, prometon, terbacil, and tebuthiuron also had reported concentrations (table 23). Of these pesticides, atrazine concentrations decreased over time (fig. 21); acetochlor, alachlor, and metolachlor concentrations remained fairly constant.

Nitrate concentrations over time are shown in figure 22 for hot-spot wells BA 437, LN 1842, and BE 1370. Nitrate concentrations at BA 437 showed the greatest fluctuations and the greatest decreases over the period of record (1996-2007) compared to nitrate concentrations at wells LN 1842 and BE 1370.

Nonparametric statistical techniques were used in exploratory data analysis and in determining trends in concentration at the three hot-spot wells using a 5-yr (2003-07) data set and the long-term data sets. In addition to scatterplots described previously for the exploratory data analysis, boxplots also were used to analyze the data graphically. After graphical analysis of the data, the Kruskal-Wallis test was used as a screening tool to examine for significant seasonality in the data sets for the hot-spot wells. For this study, data were collected quarterly, and "season" was defined by four categories (winter season, generally December, January, February, and March; spring season, generally April and May; summer season, generally June, July, and early August; and fall season, generally late August, September, October, and November). Concentrations of acetochlor, alachlor, atrazine, metolachlor, and nitrate in samples collected from 2003 to 2007 were ranked from lowest to highest; all censored data (values less than the detection limits) were assigned the lowest rank. The test compared the rank-transformed data to the categorical variable for seasonal groups (winter, spring, summer, and fall groups). If results of the Kruskal-Wallis test showed statistically significant differences in the ranked concentrations grouped by season at a significance level of 0.05 , the TukeyKramer multiple-comparison test was used to determine which seasonal groups differed from each other.

The Kruskal-Wallis and Tukey-Kramer tests showed significantly higher median concentrations of alachlor in BA 437 during the fall than during the winter (fig. 23); however, seasonality was not evident in any of the other constituents analyzed in this exploratory phase of data analysis. Because seasonality was observed for alachlor, more rigorous statistical analysis methods to test for seasonal trends (Seasonal Kendall test) were considered valid.

Contaminant concentration data were analyzed for trends in ground-water quality over time by use of the Mann-Kendall trend test and the Seasonal Kendall trend test with the level of significance set at 0.05 (p equal to 0.05 or less) (Helsel and others, 2005). The nonparametric Mann-Kendall statistic is a test for whether concentrations tend to increase or decrease with time (monotonic change) (Helsel and Hirsch, 2002, p. 326). The nonparametric Seasonal Kendall test is a modified Mann-Kendall test (Helsel and Hirsch, 2002, p. 338) that determines whether concentrations increase or decrease with time and compares relative ranks of data values from the same season. Censored data were assigned a common value lower than the lowest quantified value before ranking (all values below the reporting limit for a single pesticide compound were tied at the lowest rank). In the Seasonal Kendall test, winter data were only compared with winter data, spring data were only compared with spring data, etc. The Seasonal Kendall test statistic is the summation of all Mann-Kendall test results on the individual seasons.

Trends of selected pesticides (acetochlor, alachlor, atrazine, and metolachlor) and nitrate were determined for the hot-spot wells. Prior to 2003, data generally were collected at least annually. A change in program emphasis in 2003 resulted in quarterly sampling for the selected constituents (an increase in sampling frequency) to determine if there were any seasonal trends in the hot-spot wells. The 5-year data sets (2003-07) for wells BA 437 and LN 1842 were analyzed using the Mann-Kendall test for overall trend and the Seasonal Kendall trend test. Because of low concentrations in hot-spot well BE 1370 after the first 2 years of quarterly sampling (2003 and 2004), quarterly sampling was discontinued. As a result, well BE 1370 had an insufficient number of samples to analyze for trend using the Seasonal Kendall trend test; the 5-year data set (2003-07) for well BE 1370 was analyzed using the MannKendall trend test only. The trend tests also were conducted using additional data that included samples collected before 2003, hereafter termed "long-term data," for the hot-spot wells. The long-term data for hot-spot well BA 437 covers 1996-2007, the long-term data for hot-spot well LN 1842 covers 1991-2007, and the long-term data for hot-spot well BE 1370 covers 1998-2007. As with the 5-year data sets, the long-term data sets were analyzed using the Mann-Kendall and Seasonal Kendall trend tests. Results of the trend analyses for the 5-year and long-term data sets are presented in table 24.

The Mann-Kendall test for overall trend and the Seasonal Kendall trend test indicated a statistically significant trend for nitrate in hot-spot well BA 437 for the 5-year data set. Concentrations of nitrate had a significant downward trend indicating an improvement in water quality since 2003 . Seasonal Kendall results indicate that nitrate decreased by $25 \mathrm{mg} / \mathrm{L}$ over the 2003-07 timeframe. This same result (downward trend) was not observed when the long-term data set (1996-2007) was analyzed; there was no statistically significant trend for nitrate in the long-term data set. According to Helsel and Hirsch (2002), the fact that no trend was found does not "prove" that no trend exists; rather, there is not sufficient evidence to conclude that there is a trend in existing data at the 


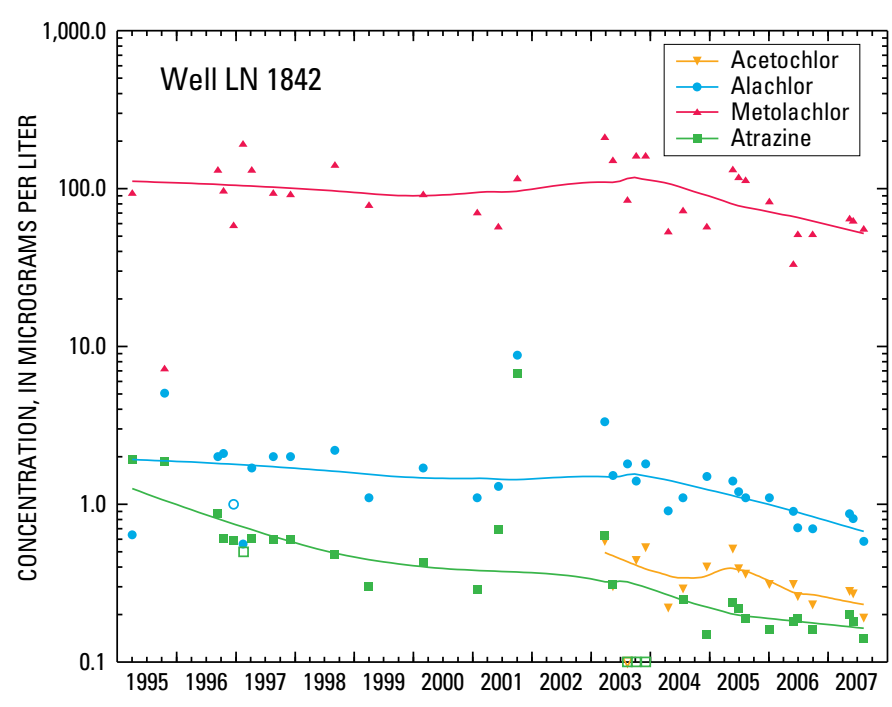

Figure 21. Concentrations of acetochlor, alachlor, metolachlor, and atrazine in samples collected from 1995 to 2007 at well LN 1842, Earl Township, Lancaster County, Pennsylvania. Lines fitted through the data are LOWESS smooth curves. Concentrations less than minimum reporting levels (MRLs) were plotted as open symbols at concentrations equal to the respective MRLs (these concentrations were included in the formulation of LOWESS smooth curves).

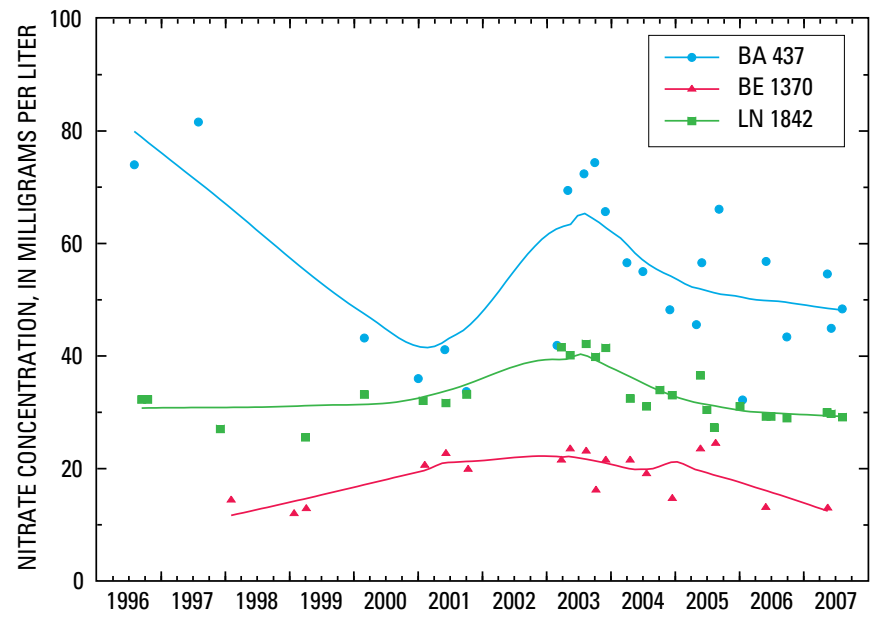

Figure 22. Nitrate concentrations in 1996-2007 for samples collected at wells BA 437, LN 1842, and BE 1370 in Pennsylvania. Lines fitted through the data are LOWESS smooth curves.

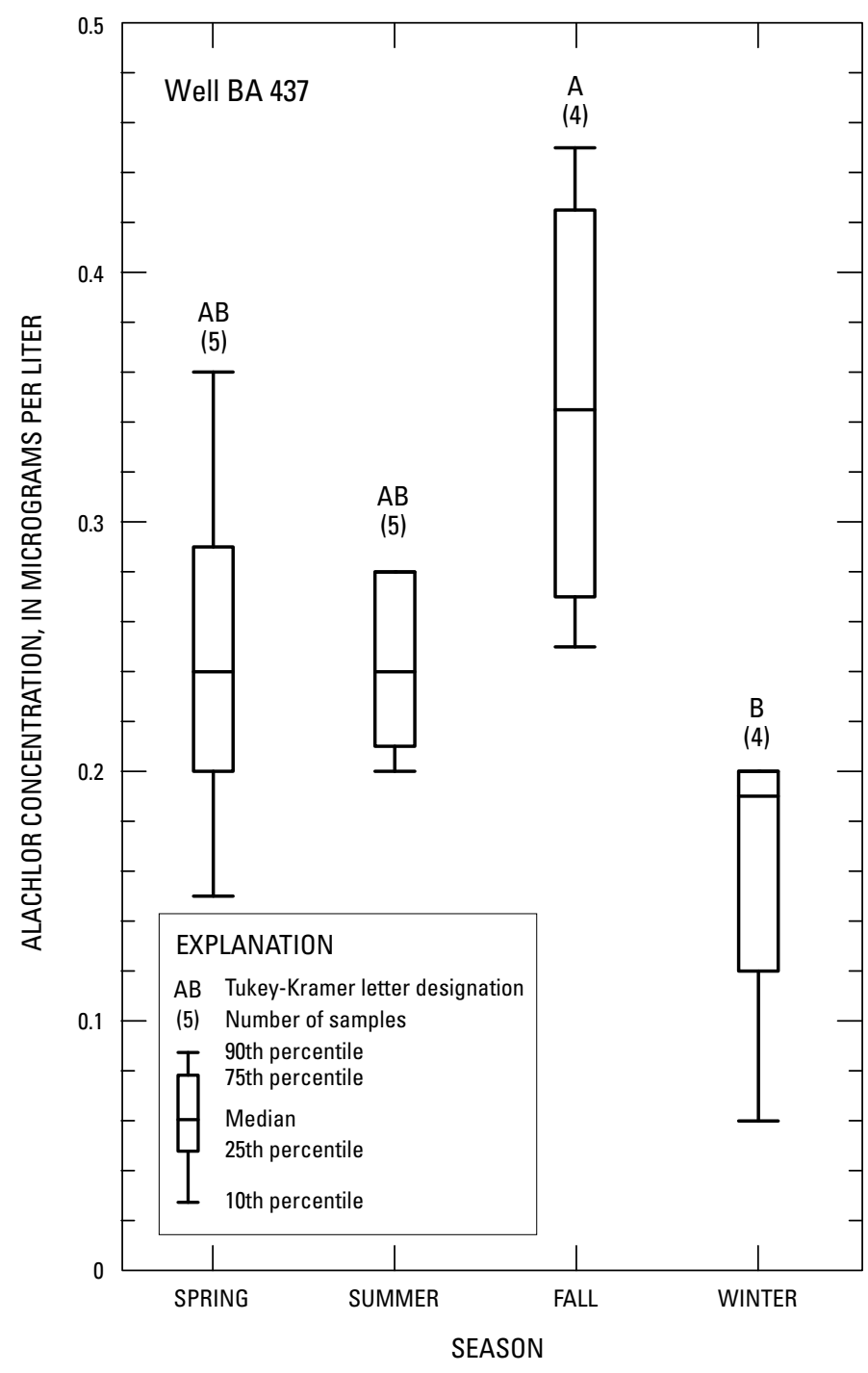

Figure 23. Range of alachlor concentrations from 2003 to 2007 by season at well BA 437, North Woodbury Township, Blair County, Pennsylvania, and results of Tukey-Kramer multiple-comparison test. 


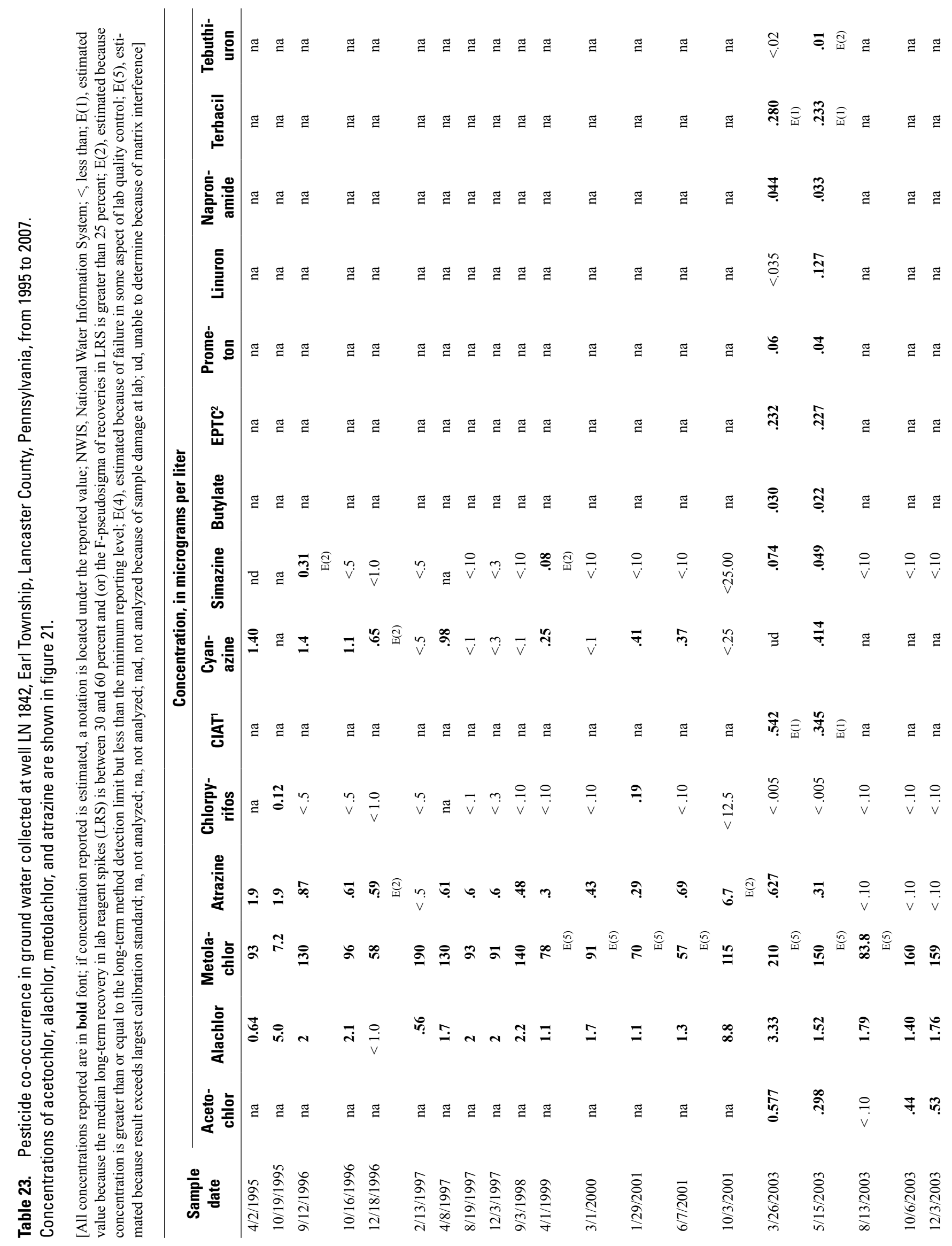




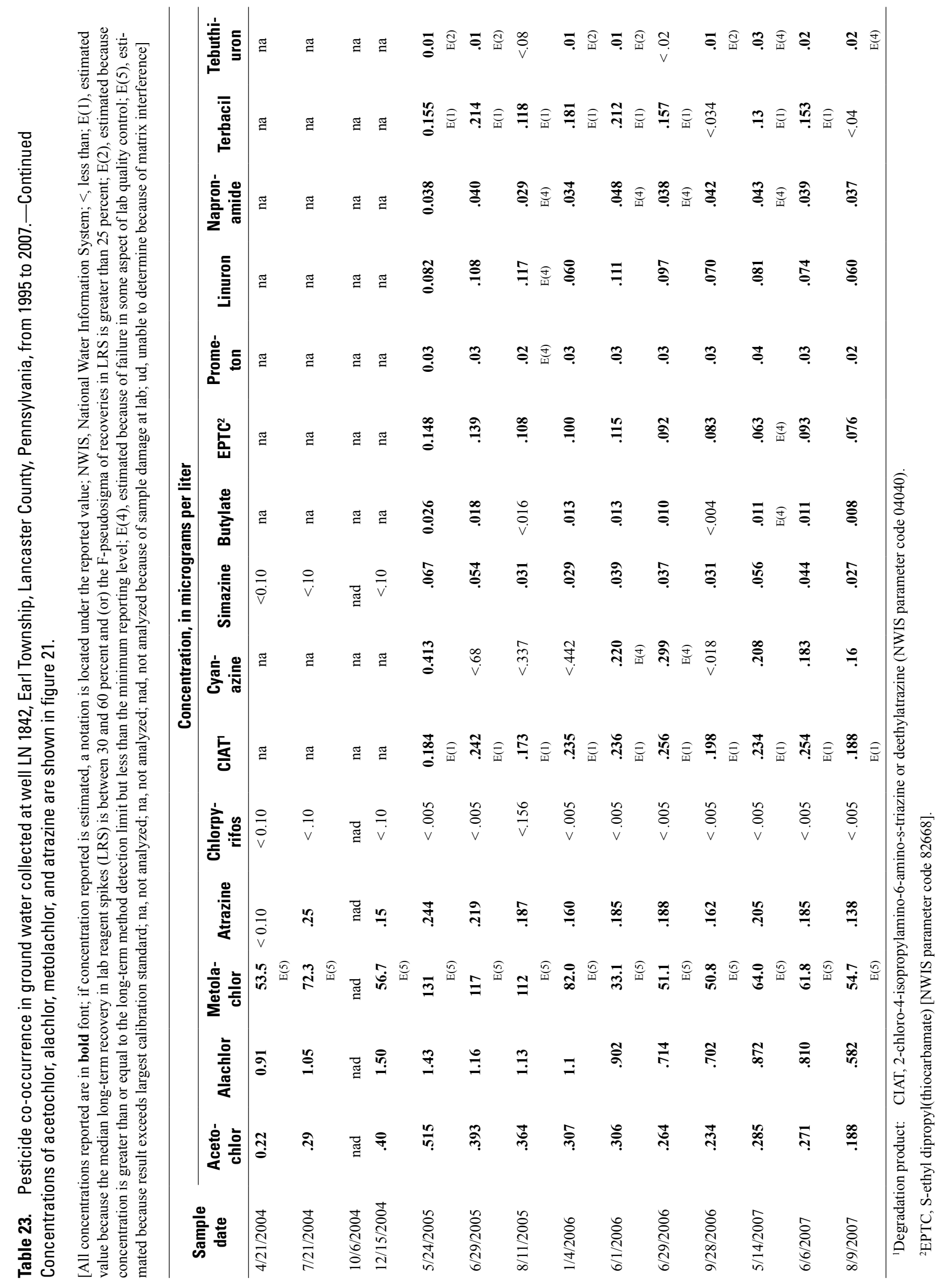




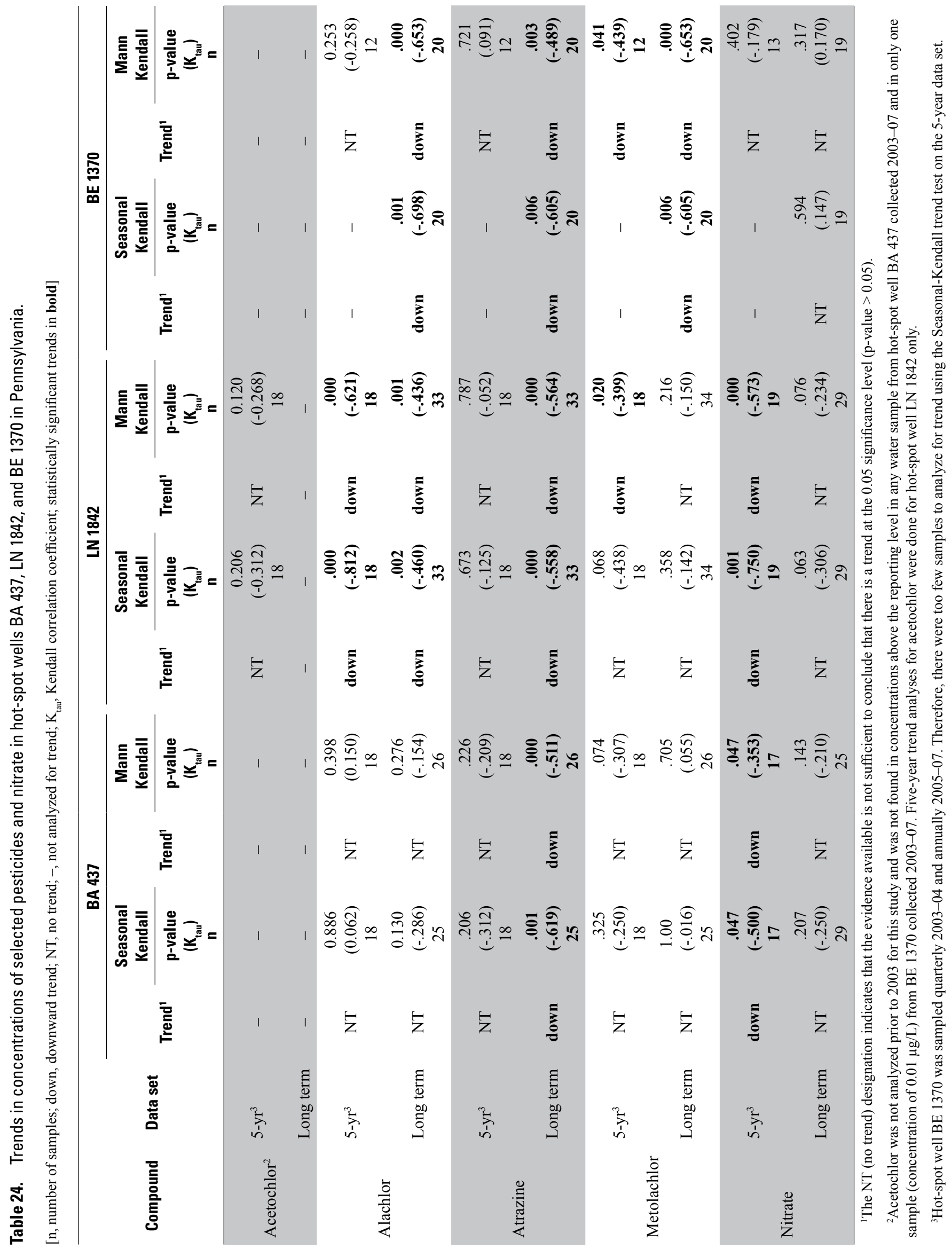


chosen level of significance. A significant downward trend was observed when analyzing the long-term data set for atrazine from hot-spot well BA 437. Seasonal Kendall results indicated concentrations of atrazine decreased by $1.43 \mu \mathrm{g} / \mathrm{L}$ over the 1996-2007 timeframe.

Concentrations of alachlor and nitrate in hot-spot well LN 1842 had statistically significant downward trends when analyzing the 5-year data set (2003-07) using the MannKendall and Seasonal Kendall trend tests. Seasonal Kendall results indicate alachlor and nitrate concentrations decreased by 1.1 and $9.1 \mathrm{mg} / \mathrm{L}$, respectively, over the 2003-07 timeframe. A significant downward trend for metolachlor also was observed using the Mann-Kendall trend test. Concentrations of metolachlor decreased by $65 \mu \mathrm{g} / \mathrm{L}$ over the 2003-07 timeframe. Additional downward trends in alachlor and atrazine were observed when the long-term data set from hot-spot well LN 1842 was analyzed. Seasonal Kendall results indicated concentrations of alachlor and atrazine decreased by 1.8 and $0.80 \mu \mathrm{g} / \mathrm{L}$, respectively, over the 1991-2007 timeframe. These downward trends in contaminant concentrations in hot-spot well LN 1842 indicate improvement in water quality.

The Mann-Kendall test for overall trend indicated statistically significant trends for metolachlor in hot-spot well BE 1370 when analyzing the 5-year data set. Mann-Kendall results indicate that metolachlor decreased by $0.26 \mu \mathrm{g} / \mathrm{L}$ over the 2003-07 timeframe, indicating an improvement in water quality. The results of the Mann-Kendall trend test on concentrations of alachlor and atrazine indicated no significant trends over the 2003-07 timeframe. However, the percentages of non-detects (data below the MRL) for the alachlor and atrazine data sets were 25 percent or greater, which decreases the statistical power of the trend test for these two constituents. Significant downward trends were observed in alachlor, atrazine, and metolachlor when analyzing the long-term data set. Seasonal Kendall results indicated concentrations of alachlor, atrazine, and metolachlor decreased by $6.6,0.33$, and 2.16 $\mu \mathrm{g} / \mathrm{L}$, respectively, over the 1998-2007 timeframe in hot-spot well BE 1370. The metolachlor data set for hot-spot well BE 1370 did not contain any non-detects, so the decreasing trend indicates an improvement in water quality with respect to this compound. Similar to the 5-year data sets for alachlor and atrazine, the long-term data sets had high percentages of nondetected values ( 40 and 15 percent, respectively), so the trend results for these two compounds are less certain.

The long-term data sets were tested to determine differences between seasons that would not be apparent using the trends tests, which assume a single monotonic pattern of trend across all seasons. This is called testing for homogeneity of trend (van Belle and Hughes, 1984; Helsel and Hirsh, 2002), which will uncover, for example, if trends for a particular constituent were due entirely to trends in one season (and no trends in the other seasons). Testing for homogeneity of trend also will uncover whether or not a constituent that was observed to have no statistically significant trends really had trends in the different seasons (upward and downward) that negated each other. The results of the within-season analysis are presented in table 25. Analyzing the long-term data from each season individually using the Mann-Kendall test for trend showed that the downward trend (Seasonal Kendall trend test results) observed for atrazine in hot-spot well BA 437 (table 24) was due entirely to a significant downward trend in the summer (table 25). The trend test for homogeneity also indicated a downward trend in alachlor concentrations in the summer (table 25); however, a trend was not observed for alachlor in that well using the Seasonal Kendall trend test (table 24). The fact that no trend was observed for alachlor using the Seasonal Kendall trend test indicates the downward trend was likely weak. The downward trend for alachlor in well LN 1842 (table 24) was due to significant downward trends in the summer and fall (table 25). Similarly, the downward trend observed using the Seasonal Kendall test on the long-term data for atrazine in well LN 1842 (table 24) was the result of significant downward trends in the spring and fall (table 25). Finally, the results of the Seasonal Kendall test indicating downward trends in the long-term data set for atrazine and metolachlor in hot-spot well BE 1370 (table 24) were due entirely to significant downward trends in the winter samples (table 25). The downward trend for alachlor in hotspot well BE 1370 (table 24) was the result of significant downward trends in the winter and spring (table 25).

Table 25. Within-season analysis of long-term trends in concentrations of selected pesticides and nitrate in hotspot wells BA 437, LN 1842, and BE 1370 in Pennsylvania using the Mann-Kendall test for trend.

(Table continued on next page)

[n, number of samples; down, downward trend; NT, no trend (at the 0.05 significance level); $\mathrm{K}_{\text {tau }}$, Kendall correlation coefficient; statistically significant trends in bold]

\begin{tabular}{|c|c|c|}
\hline \multirow[b]{3}{*}{ Compound $^{1}$} & \multicolumn{2}{|c|}{ BA 437} \\
\hline & \multicolumn{2}{|c|}{ Summer } \\
\hline & Trend & $\begin{array}{c}p \text {-value } \\
\left(K_{\text {tau }}\right) \\
n\end{array}$ \\
\hline Alachlor & down & $\begin{array}{c}0.004 \\
(-0.733) \\
10\end{array}$ \\
\hline Atrazine & down & $\begin{array}{c}.0002 \\
(-.933) \\
10\end{array}$ \\
\hline Metolachlor & NT & $\begin{array}{c}0.928 \\
(0.044) \\
10\end{array}$ \\
\hline Nitrate & NT & $\begin{array}{c}0.059 \\
(-0.528) \\
9\end{array}$ \\
\hline
\end{tabular}

${ }^{1}$ Acetochlor was not analyzed prior to 2003 for this study and was not included in the within-season analysis of long-term data. 
Table 25. Within-season analysis of long-term trends in concentrations of selected pesticides and nitrate in hot-spot wells BA 437, LN 1842, and BE 1370 in Pennsylvania using the Mann-Kendall test for trend.-Continued

[n, number of samples; down, downward trend; NT, no trend (at the 0.05 significance level); $\mathrm{K}_{\text {tau }}$, Kendall correlation coefficient; statistically significant trends in bold]

\begin{tabular}{|c|c|c|c|c|c|c|c|c|c|c|}
\hline \multirow[b]{3}{*}{ Compound ${ }^{1}$} & \multicolumn{6}{|c|}{ LN 1842} & \multicolumn{4}{|c|}{ BE 1370} \\
\hline & \multicolumn{2}{|c|}{ Spring } & \multicolumn{2}{|c|}{ Summer } & \multicolumn{2}{|c|}{ Fall } & \multicolumn{2}{|c|}{ Winter } & \multicolumn{2}{|c|}{ Spring } \\
\hline & Trend & $\begin{array}{c}\text { p-value } \\
\left(K_{\text {tau }}\right) \\
n\end{array}$ & Trend & $\begin{array}{c}\text { p-value } \\
\left(K_{\text {tau }}\right) \\
n\end{array}$ & Trend & $\begin{array}{c}\text { p-value } \\
\left(K_{\text {tau }}\right) \\
n\end{array}$ & Trend & $\begin{array}{c}\text { p-value } \\
\left(K_{\text {tau }}\right) \\
n\end{array}$ & Trend & $\begin{array}{c}\text { p-value } \\
\left(K_{\text {tau }}\right) \\
n\end{array}$ \\
\hline Alachlor & NT & $\begin{array}{c}0.118 \\
(-0.444) \\
9\end{array}$ & down & $\begin{array}{c}0.036 \\
(-0.714) \\
7\end{array}$ & down & $\begin{array}{c}0.036 \\
(-0.583) \\
9\end{array}$ & down & $\begin{array}{c}0.015 \\
(-0.810) \\
7\end{array}$ & down & $\begin{array}{c}0.044 \\
(-0.619) \\
7\end{array}$ \\
\hline Atrazine & down & $\begin{array}{c}0.016 \\
(-.667) \\
9\end{array}$ & NT & $\begin{array}{c}0.133 \\
(-0.524) \\
7\end{array}$ & down & $\begin{array}{c}.036 \\
(-.583) \\
9\end{array}$ & down & $\begin{array}{c}.048 \\
(-.667) \\
7\end{array}$ & NT & $\begin{array}{c}0.095 \\
(-0.571) \\
7\end{array}$ \\
\hline Metolachlor & NT & $\begin{array}{c}1.00 \\
(0.000) \\
9\end{array}$ & NT & $\begin{array}{c}0.548 \\
(-0.238) \\
7\end{array}$ & NT & $\begin{array}{c}0.834 \\
(-0.083) \\
9\end{array}$ & down & $\begin{array}{c}.023 \\
(-.762) \\
7\end{array}$ & NT & $\begin{array}{c}0.095 \\
(-0.571) \\
7\end{array}$ \\
\hline
\end{tabular}

${ }^{1}$ Acetochlor was not analyzed prior to 2003 for this study and was not included in the within-season analysis of long-term data.

\section{Pesticides and Pesticide-Degradation Products in Ground Water near Hot- Spot Wells}

Hot-spot wells yield water with concentrations of pesticides greater than or equal to at least one action level specified in the PPGWS (appendix 4). PDA has designated three areas of special ground-water protection in Berks, Blair, and Lancaster Counties (a hot-spot well is located in each of these areas). Descriptions of the hot-spot wells and the occurrence of pesticide compounds in well water were presented earlier. This section describes the results of sampling conducted to understand the co-occurrence of pesticides and pesticide-degradation products in ground water near the hotspot wells.

Pesticides are applied as the "parent" chemical. As pesticides age in the soil and in water, they are biologically degraded and chemically transformed into chemical compounds different than the parent. As the breakdown takes place, typically in the soil zone, the concentrations of the "degradation products" increase and the concentrations of the parent pesticides decrease. To understand the extent of natural breakdown of pesticides, it is important to analyze for parent pesticides and degradation products. A total of 16 sites ( 15 wells and 1 spring) were sampled once to characterize the distribution of 15 pesticides, 39 pesticide breakdown products (degradates), and other indicators of water-quality degradation, such as bromide, chloride, and nitrate (appendix 3). 


\section{Berks County, Oley Township}

In August 2005, hot-spot well BE 1370, BE SP20 (a spring adjacent to the farmhouse supplied by well BE 1370), and five rural domestic wells at neighboring residences were sampled (table 3, fig. 24). For this study, acetamide pesticides include parent compounds and degradates of acetochlor, alachlor, dimethenamid, metolachlor, and propachlor; triazine and phenylurea pesticides include parent compounds and degradates of atrazine, bromacil, cyanazine, prometon, propazine, simazine, diuron, fluometuron, and linuron (table 9). Results of the analyses of ground-water samples are summarized in tables 26,27 , and 28.

The water from hot-spot well BE 1370 and spring BE SP20 have similar concentrations of parent compounds and degradation products from the acetamide and triazine and phenylurea pesticide groupings. There are 3 to 4 times as many degradation products with up to 10 times the concentrations of the alachlor and metolachlor parent compounds in water from hot-spot well BE 1370 and spring BE SP20 compared to the neighboring wells sampled.
Waters from wells near the hot-spot well have variable water-quality characteristics. To the southwest of BE 1370 , waters from wells completed in shallow and deeper parts of the aquifer (wells BE 1298 and BE 1775) have concentrations of pesticides most similar to the hot-spot well; the difference is that the acetamide parent compounds were not detected in samples from BE 1298 and BE 1775. Well BE 1774, the deepest well sampled, and well BE 1776, both to the south of the well BE 1370, had similarities in ground-water quality. Water from these two wells had no parent compounds at the OGRL reporting levels of 0.02 to $0.05 \mu \mathrm{g} / \mathrm{L}$, concentrations of degradation products at least a factor of two less than the hot spot, and acetamide degradation products more prevalent in number and higher in concentration than triazine and phenylurea degradation products in the same water samples. A trace of acetamide degradation products was reported above the MRL in water from well BE 1773, adjacent to the Little Manatawny Creek.

Table 26. Summary of selected well and water-quality characteristics with associated numbers of pesticide parent compounds and numbers of pesticide degradates in water from well BE 1370, five neighboring wells, and a spring, Oley Township, Berks County, Pennsylvania, August 18-23, 2005.

[Water use: R, residence; L, Livestock; N, nitrogen; D.O., dissolved oxygen; $\mathrm{Cl}$, chloride; $\mathrm{Cl}: \mathrm{Br}$, mass (weight) ratio of chloride and bromide concentrations; $\mu \mathrm{g} / \mathrm{L}$, micrograms per liter; $<$, less than; RL, reporting level; -, no data]

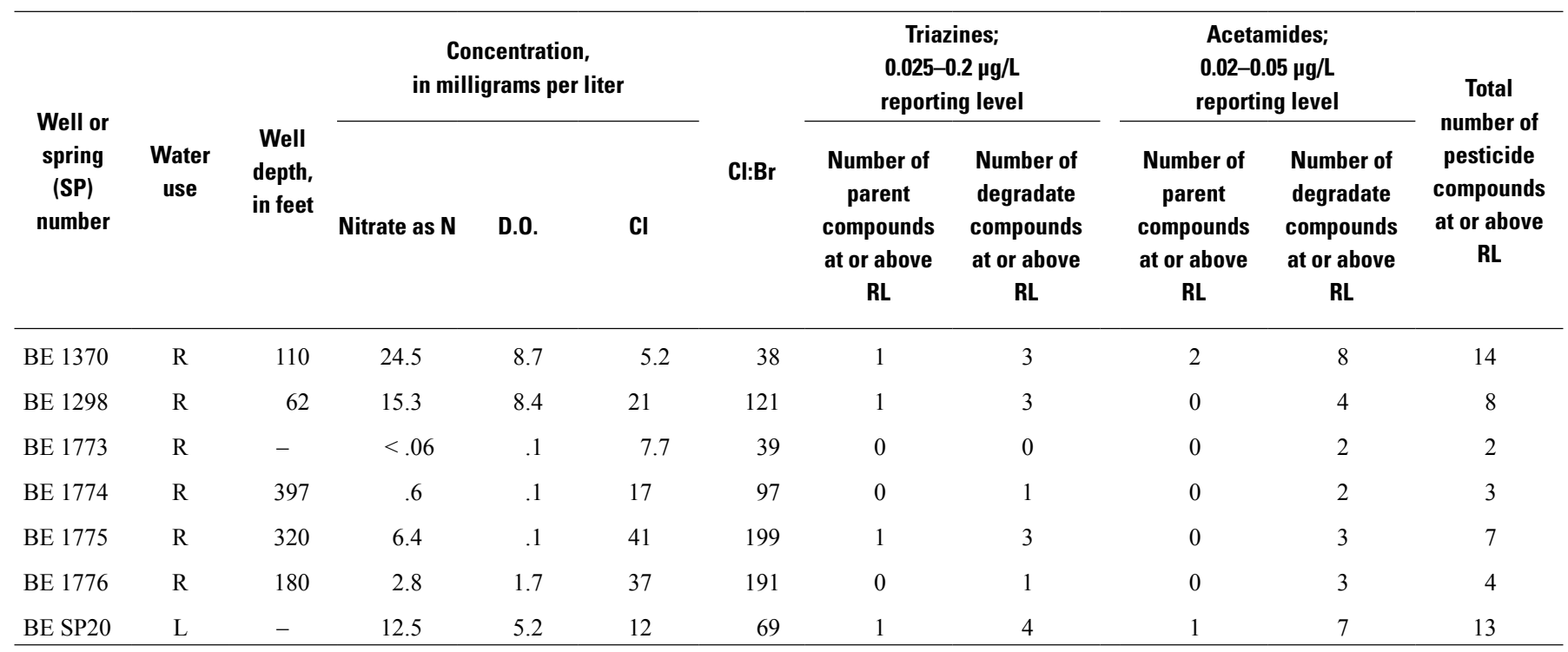




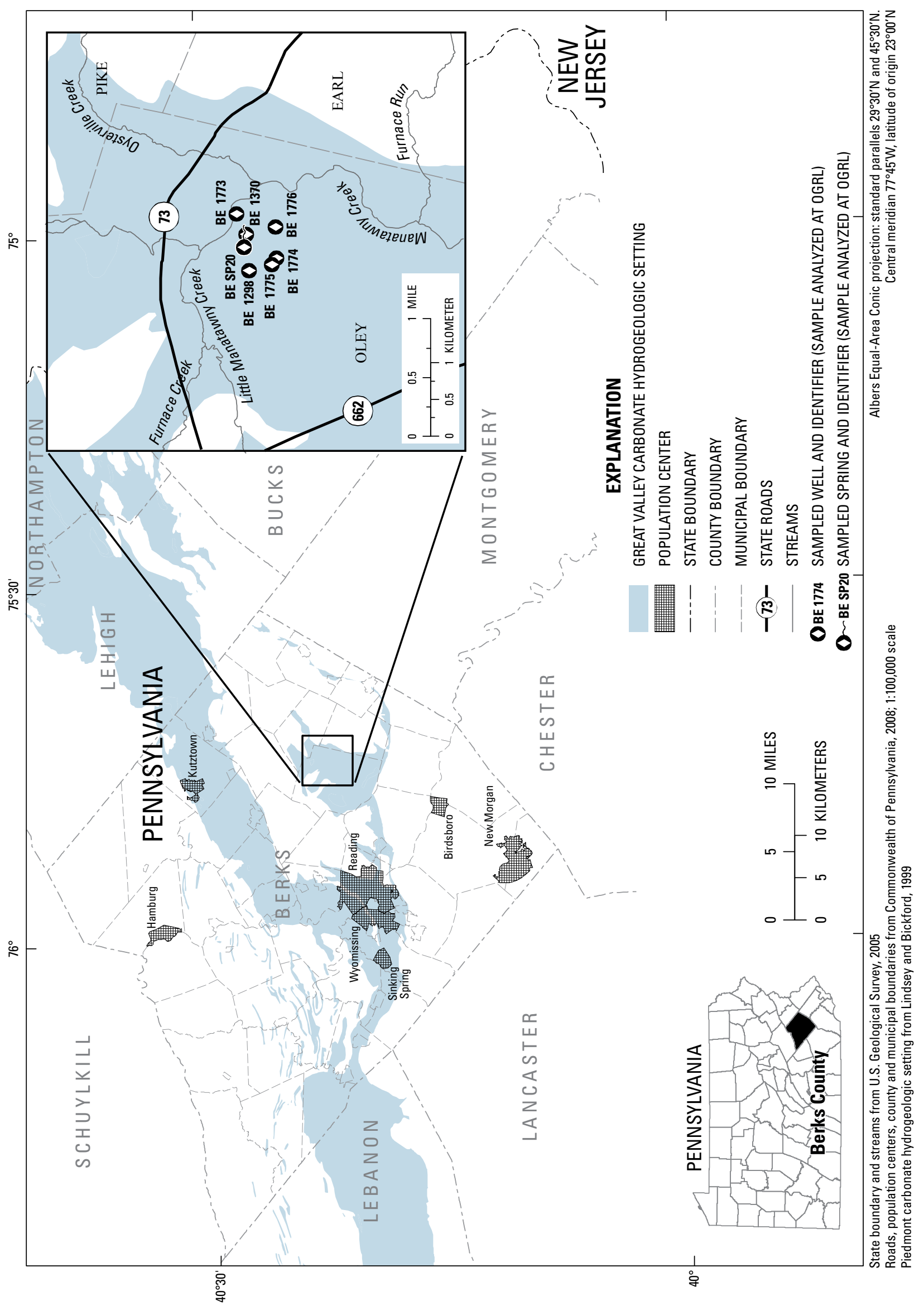






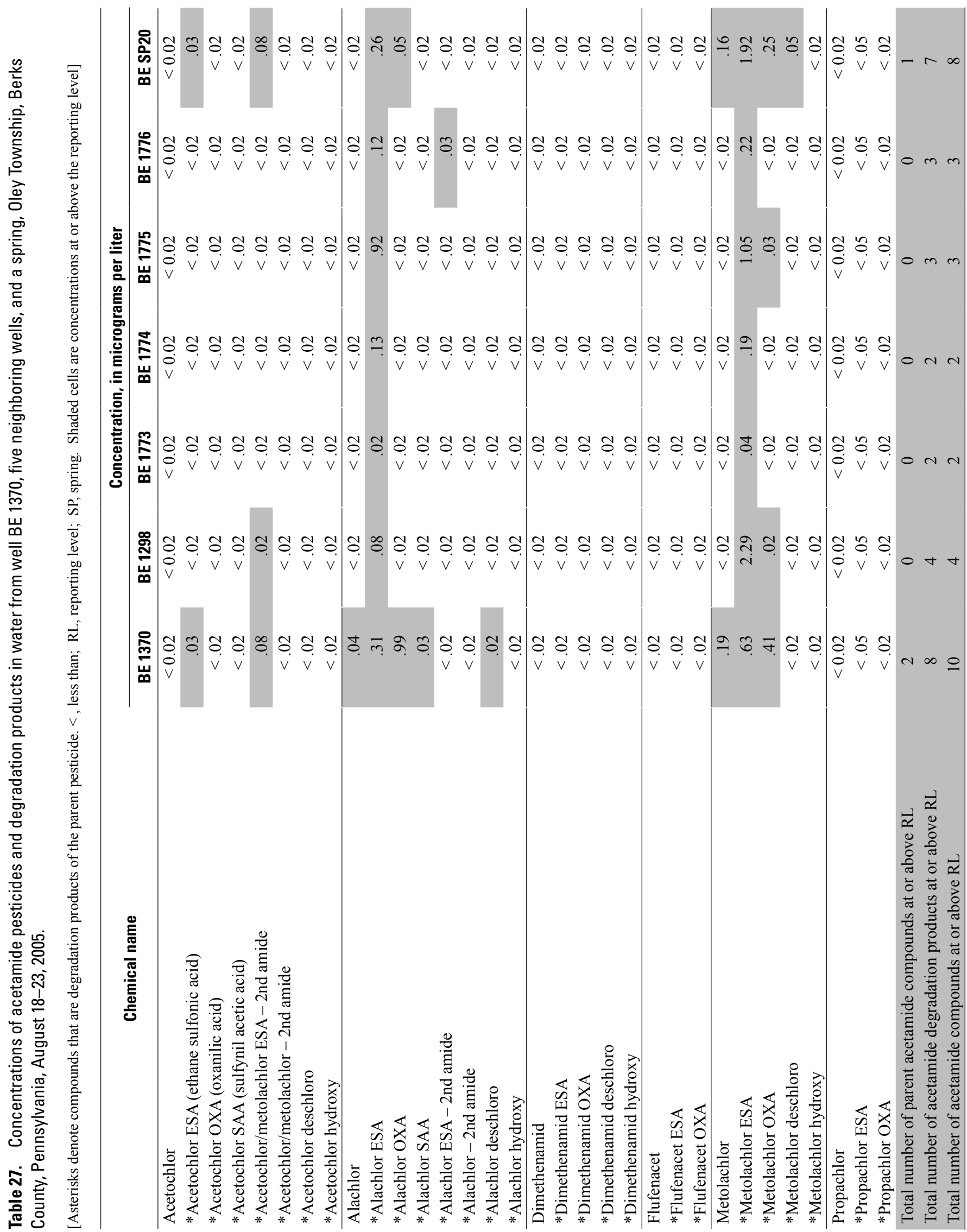




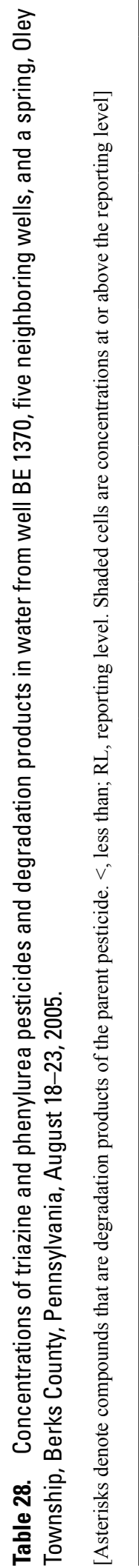

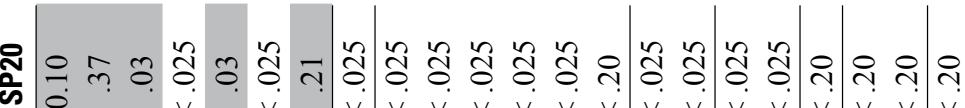

岗

ڤ

㟧

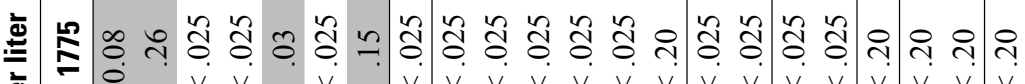

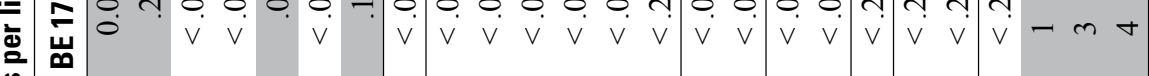

产

ฟ E

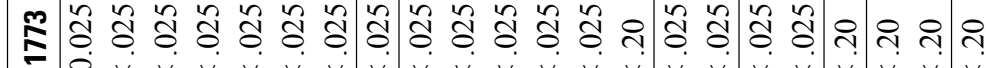
ü

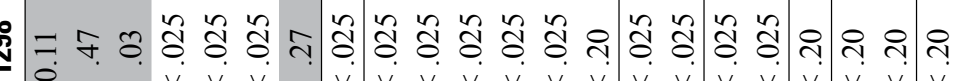

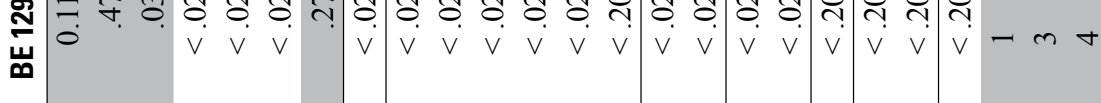

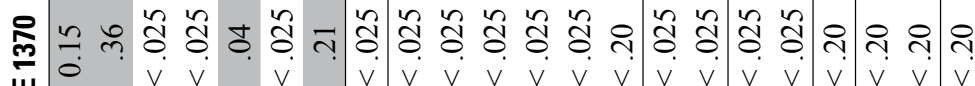

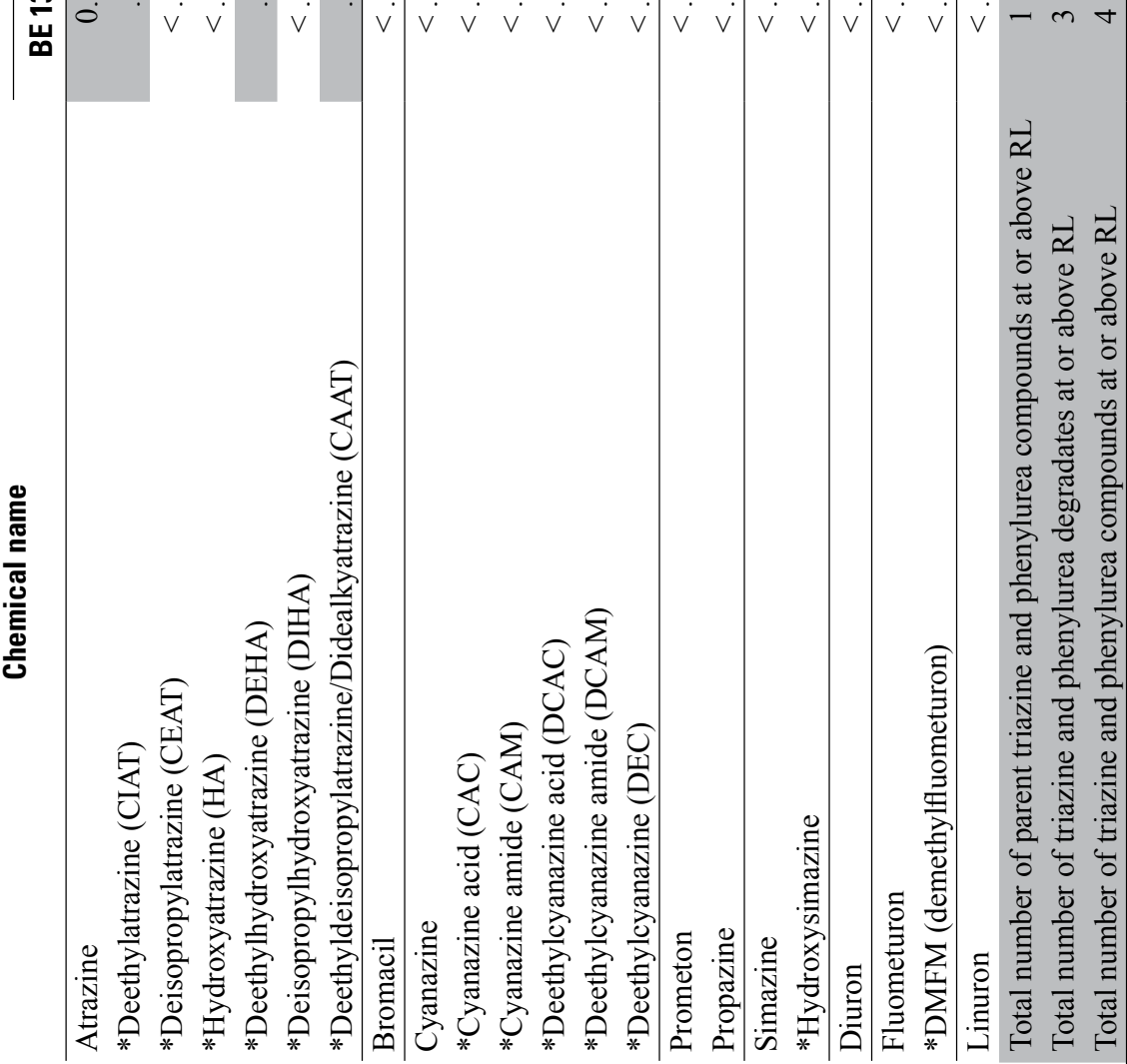




\section{Blair County, North Woodbury Township}

Concentrations of nitrate and pesticides in water from well BA 437 have exceeded MCLs for years. The following includes a brief history of monitoring, a description and summary of the major findings from the borehole testing, and a description and summary of the water-quality results.

In 1984, USGS conducted a regional assessment of well yields and ground-water quality in an area that included Blair County (Becher, 1996). The assessment showed that water from well BA 437 had high concentrations of chloride $(470 \mathrm{mg} / \mathrm{L})$, nitrate $(100 \mathrm{mg} / \mathrm{L}$ as nitrogen $)$, and pesticides (20 $\mu \mathrm{g} / \mathrm{L}$ of alachlor and $11 \mu \mathrm{g} / \mathrm{L}$ of atrazine). In 1996, PDA initiated a surveillance program of the ground water at well BA 437 to monitor long-term changes in the concentration of nitrate and pesticides. Because of concerns over the concentrations of nitrate in ground water by communities neighboring North Woodbury Township, USGS conducted an investigation of water sources and nitrate origin for the Borough of Martinsburg (Lindsey and Koch, 2004). Lindsey and Koch (2004, p. 35) reported that well BA 437 was near the southern extent of the zone of contribution of ground water to the supply wells for Martinsburg. Surveillance results at well BA 437 indicated the persistence of high concentrations of pesticides; hence, PDA requested in early 2005 that USGS investigate the occurrence of pesticide breakdown products and conduct detailed borehole tests to determine whether the high concentrations were present only in shallow parts of the aquifer.

In August 2005, borehole testing at well BA 437 included video, caliper, flowmeter, and geophysical logging to identify water-bearing fractures in the rock. The total well depth is $106 \mathrm{ft}$ below land surface (bls), and the well is cased to $21 \mathrm{ft}$ bls with a 6-in. diameter steel casing. The static water level at the start of testing was $33 \mathrm{ft}$ bls. The testing showed major fractures at 43,45 , and $48 \mathrm{ft}$ bls and numerous smaller fractures at 68,74 , and $97-99 \mathrm{ft}$ bls. The fractures in the 43-48 ft interval were termed the shallow water-bearing zone, and the fractures between 68 and $99 \mathrm{ft}$ were termed the deep water-bearing zone. Water conductivity showed a sudden increase at $101 \mathrm{ft}$ bls, indicating an increase in dissolved solids content and correspondingly higher water density. Bedding surfaces had an average orientation (strike) of N. $26^{\circ} \mathrm{E}$. and a dip of $61^{\circ} \mathrm{NW}$. On August 30, 2005, an inflatable barrier (packer) was set at $65 \mathrm{ft}$ bls to separate the shallow and deep water-bearing zones. A submersible pump positioned above the barrier showed the seal between the zones was tight. Pumping data showed a yield for the shallow zone of about $2 \mathrm{gal} / \mathrm{min}$. After purging over three volumes of water from the shallow zone, a water-quality sample was collected. On August 31,2005, the submersible sampling pump was positioned below the inflatable barrier. Pumping data indicated a yield of less than $0.25 \mathrm{gal} / \mathrm{min}$ for the deep zone. After 6 hours of purging, a water-quality sample was collected from the deep zone.

To summarize the borehole logging of well BA 437:
1. The casing appears intact. Minor amounts of water seep into the borehole above the static water level and below the base of the casing.

2. The well yield is chiefly from a shallow water-bearing zone at 43-48 ft bls where fractures and other openings in the rock connect with the borehole. A deep water-bearing zone at $68-99 \mathrm{ft}$ is a source of minor amounts of water.

3. Sustained well yield, without significant drawdown of water level, is about $2 \mathrm{gal} / \mathrm{min}$. The deep zone yields less than $0.25 \mathrm{gal} / \mathrm{min}$.

4. Water at the base of the borehole has relatively high dissolved solids content.

The detailed water-quality sampling and testing at well BA 437 was used to compare concentrations of chloride, nitrate, and pesticides in water from the shallow and deep zones. On September 7, 2005, a composite sample was collected from the open borehole of well BA 437 to compare to the samples from the shallow and deep zones of well BA 437 and to samples from neighboring wells. The neighboring wells included a commercial well (BA 643) historically used for pesticide mixing and handling; three rural domestic wells at residences (BA 642, BA 644, and BA 645); and the nearest production well for the Borough of Martinsburg (BA 332) (table 3, fig. 25). Results of the analyses of ground-water samples are summarized in tables 29,30 , and 31 .

At well BA 437, the nitrate concentrations in the shallow and deep zones were $61.7 \mathrm{mg} / \mathrm{L}$ and $28.8 \mathrm{mg} / \mathrm{L}$, respectively. The composite sample, with a nitrate concentration of $66.1 \mathrm{mg} / \mathrm{L}$, is further evidence that most of the water yield originates in the shallow zone, and the nitrate contamination is greatest in that zone. The concentration in composite samples has remained in the 35-75 mg/L as N range since 1996 (the USEPA MCL for nitrate in public drinking water is $10 \mathrm{mg} / \mathrm{L}$ as $\mathrm{N})$.

The chloride concentration in the shallow zone at well BA 437 was $196 \mathrm{mg} / \mathrm{L}$. The deep zone was only slightly more enriched in chloride $(228 \mathrm{mg} / \mathrm{L})$. Although the chloride concentrations were high, the magnitude was about one half the concentration measured by USGS in 1984. The USEPA secondary MCL for drinking water for chloride of $250 \mathrm{mg} / \mathrm{L}$ was not exceeded. The ratio of chloride to bromide $(\mathrm{Cl}: \mathrm{Br})$ is an indicator of whether the chloride is from (a) halite $(\mathrm{NaCl}$ - either naturally occurring in the rock or from road salt), (b) sewage, or (c) a mixture of sewage and halite. The relatively large $\mathrm{Cl}: \mathrm{Br}$ value of about 4,000 in the deep-zone sample indicates a halite source. The $\mathrm{Cl}: \mathrm{Br}$ value of about 700 in the shallow zone suggests a mixture of halite and sewage sources for the chloride in ground water. It is possible that the halite source is, at least in part, from road salt stored adjacent to the well. The high conductance water noted at the bottom of the well is consistent with the water-quality results.

The triazine herbicides (atrazine, bromacil, and prometon) and the acetamide herbicides (metolachlor and alachlor) 


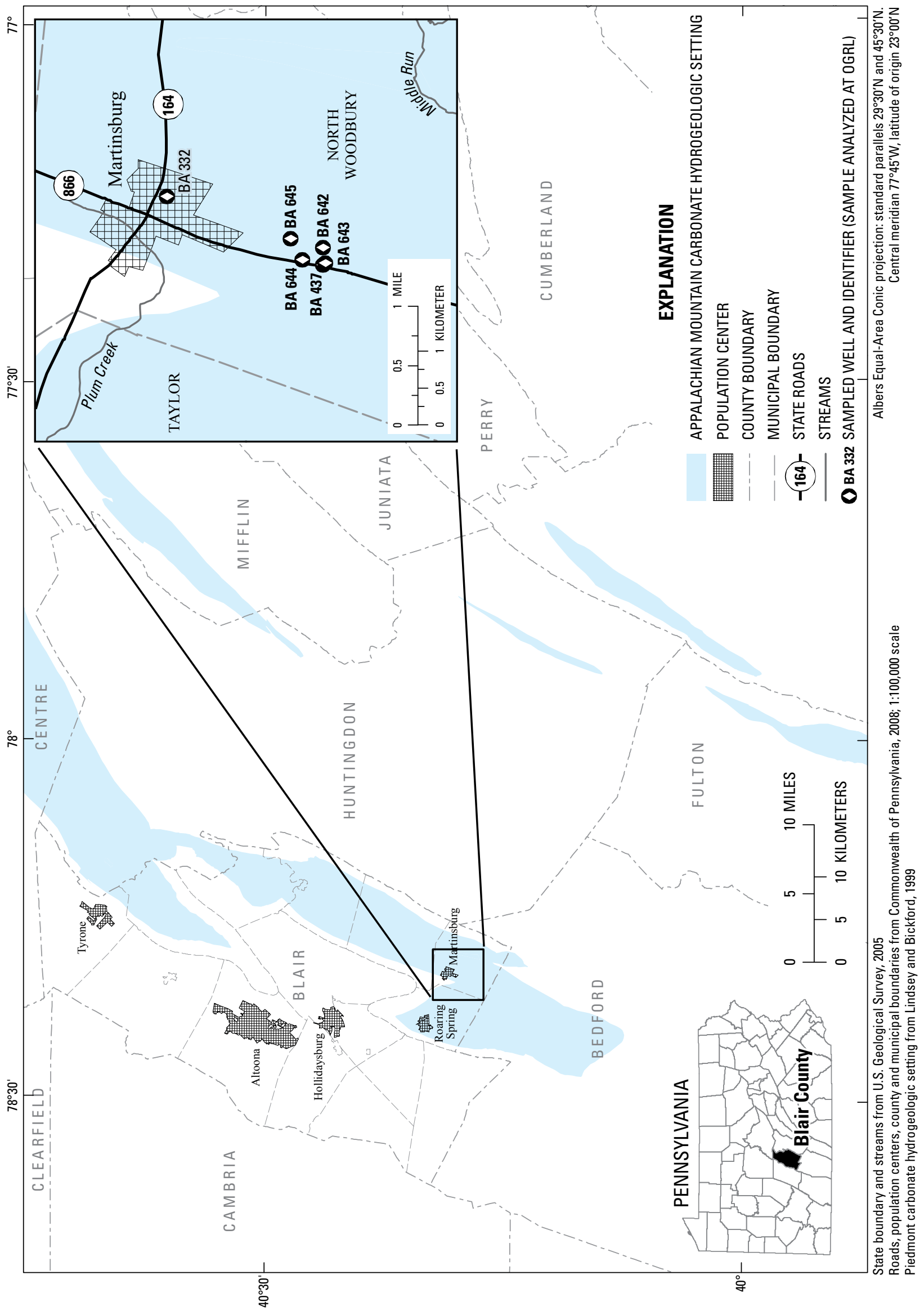

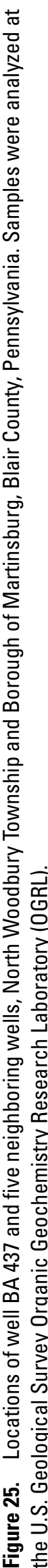


Table 29. Summary of selected well and water-quality characteristics with associated numbers of pesticide parent compounds and numbers of pesticide degradates in water from well BA 437 and five neighboring wells, North Woodbury Township and Borough of Martinsburg, Blair County, Pennsylvania, August 30 through September 8, 2005.

[RL, reporting level; $\mu \mathrm{g} / \mathrm{L}$, micrograms per liter; D.O., dissolved oxygen; $\mathrm{Cl}$, chloride; $\mathrm{Cl}$ :Br, mass (weight) ratio of chloride and bromide concentrations; $\mathrm{N}$, nitrogen; < , less than. Flow-path location: Up, Upgradient of hot spot; Down, Downgradient of hot spot. Water use: R, residence; NC, non-consumptive; P, public supply. Sample interval: S, shallow; D, deep; M, mixture of shallow and deep; -, no data]

\begin{tabular}{|c|c|c|c|c|c|c|c|c|c|c|c|c|c|}
\hline $\begin{array}{c}\text { Well } \\
\text { number }\end{array}$ & $\begin{array}{c}\text { Flow- } \\
\text { path } \\
\text { location }\end{array}$ & $\begin{array}{l}\text { Water } \\
\text { use }\end{array}$ & $\begin{array}{l}\text { Well } \\
\text { depth, } \\
\text { in feet }\end{array}$ & $\begin{array}{l}\text { Sample } \\
\text { interval }\end{array}$ & \multicolumn{3}{|c|}{$\begin{array}{c}\text { Concentration, } \\
\text { in milligrams per liter }\end{array}$} & $\mathrm{Cl}: \mathrm{Br}$ & \multicolumn{2}{|c|}{$\begin{array}{c}\text { Triazines; } \\
0.025-0.2 \mu \mathrm{g} / \mathrm{L} \\
\text { reporting level }\end{array}$} & \multicolumn{2}{|c|}{$\begin{array}{c}\text { Acetamides; } \\
0.02-0.05 \mu \mathrm{g} / \mathrm{L} \\
\text { reporting level }\end{array}$} & $\begin{array}{c}\text { Total } \\
\text { number of } \\
\text { pesticide } \\
\text { com- } \\
\text { pounds at } \\
\text { or above } \\
\text { RL }\end{array}$ \\
\hline BA 437 & Hot spot & $\mathrm{NC}$ & $<65$ & $\mathrm{~S}$ & 61.7 & 0.3 & 196 & 723 & 4 & 6 & 2 & 12 & 24 \\
\hline BA 437 & Hot spot & $\mathrm{NC}$ & 105 & $\mathrm{D}$ & 28.8 & - & 228 & 4,071 & 4 & 10 & 3 & 10 & 27 \\
\hline BA 437 & Hot spot & $\mathrm{NC}$ & 105 & M & 66.1 & .5 & 206 & 3,029 & 5 & 6 & 2 & 11 & 24 \\
\hline BA 644 & Down & $\mathrm{R}$ & 150 & - & 2.2 & .1 & 64 & 2,065 & 6 & 7 & 2 & 9 & 24 \\
\hline BA 645 & Down & $\mathrm{R}$ & 207 & - & 11.7 & 5.3 & 76 & 2,000 & 1 & 2 & 1 & 6 & 10 \\
\hline
\end{tabular}

${ }^{1}$ Production well for Borough of Martinsburg, Pa. 


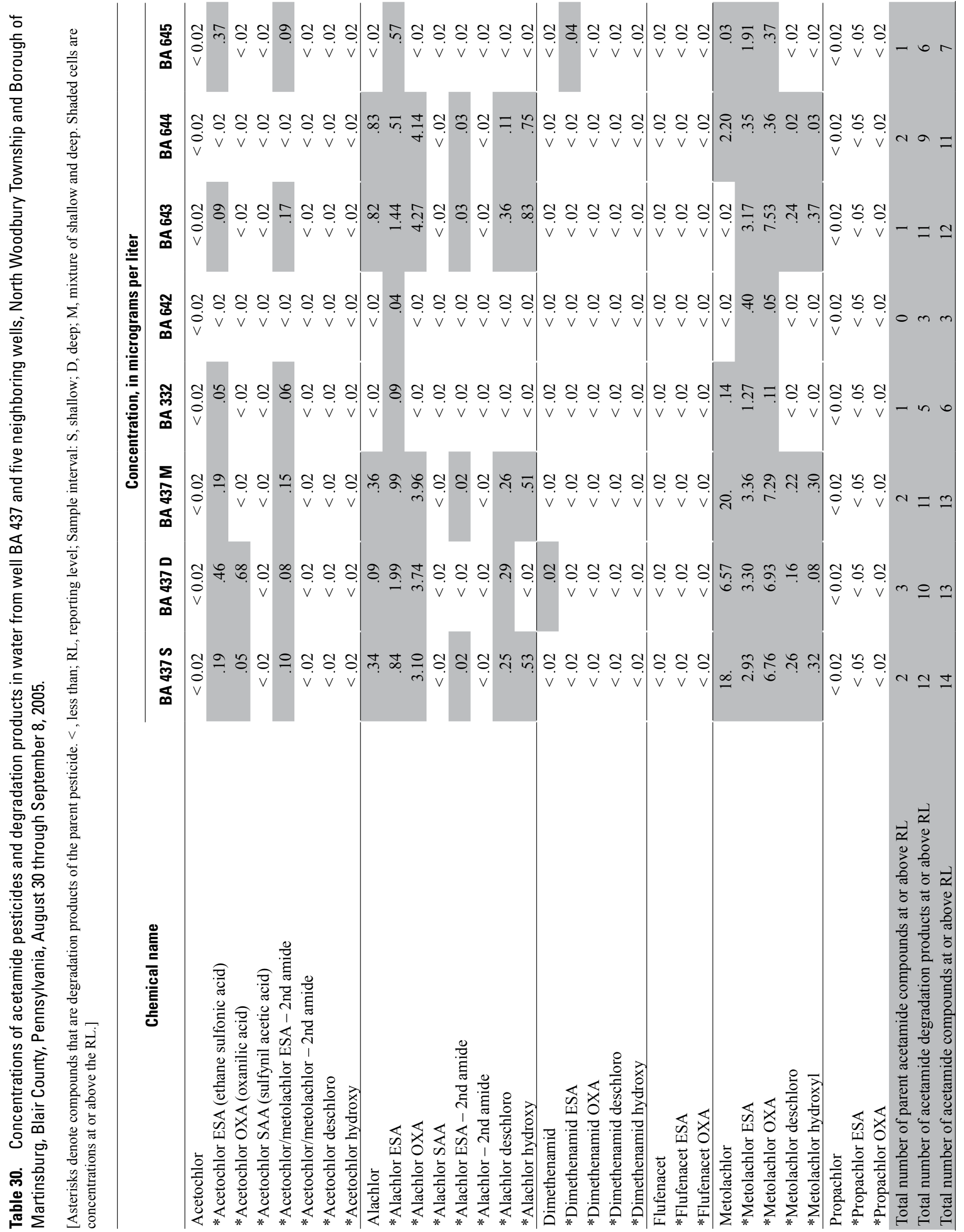




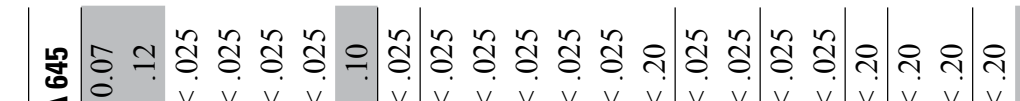

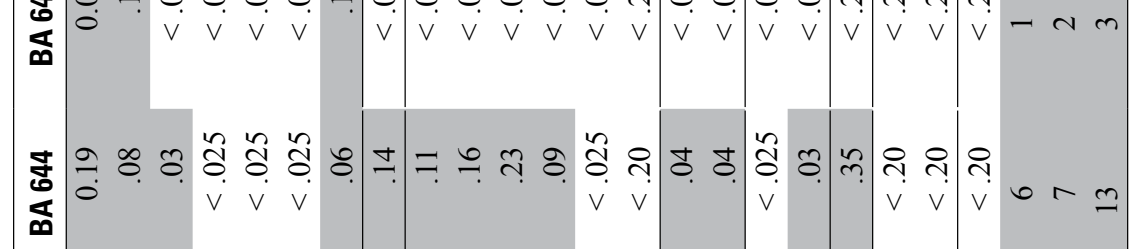

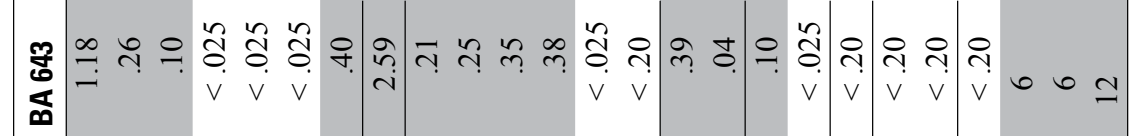

₹

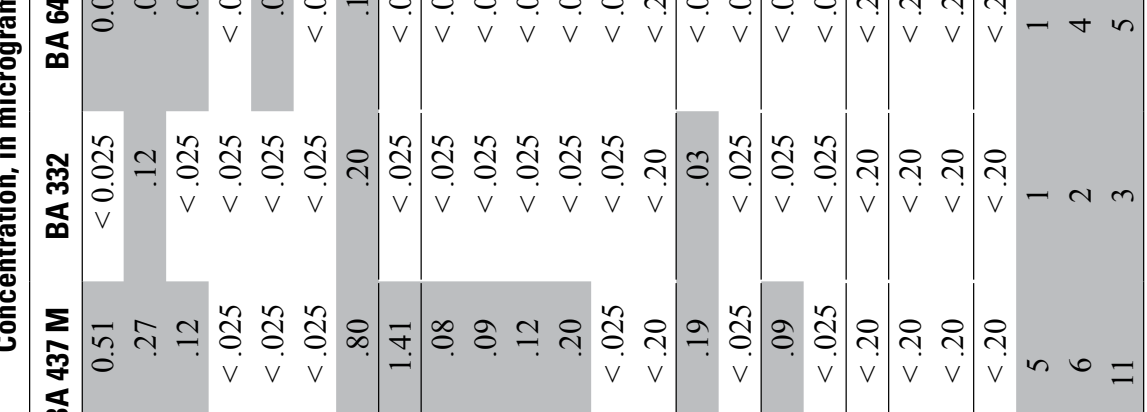
ธ

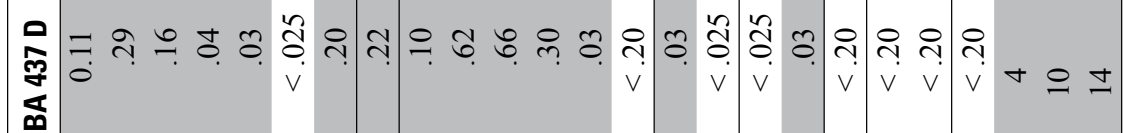

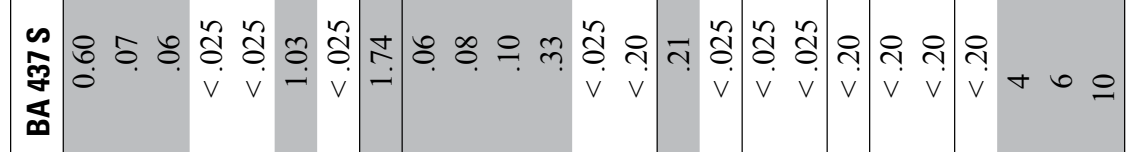

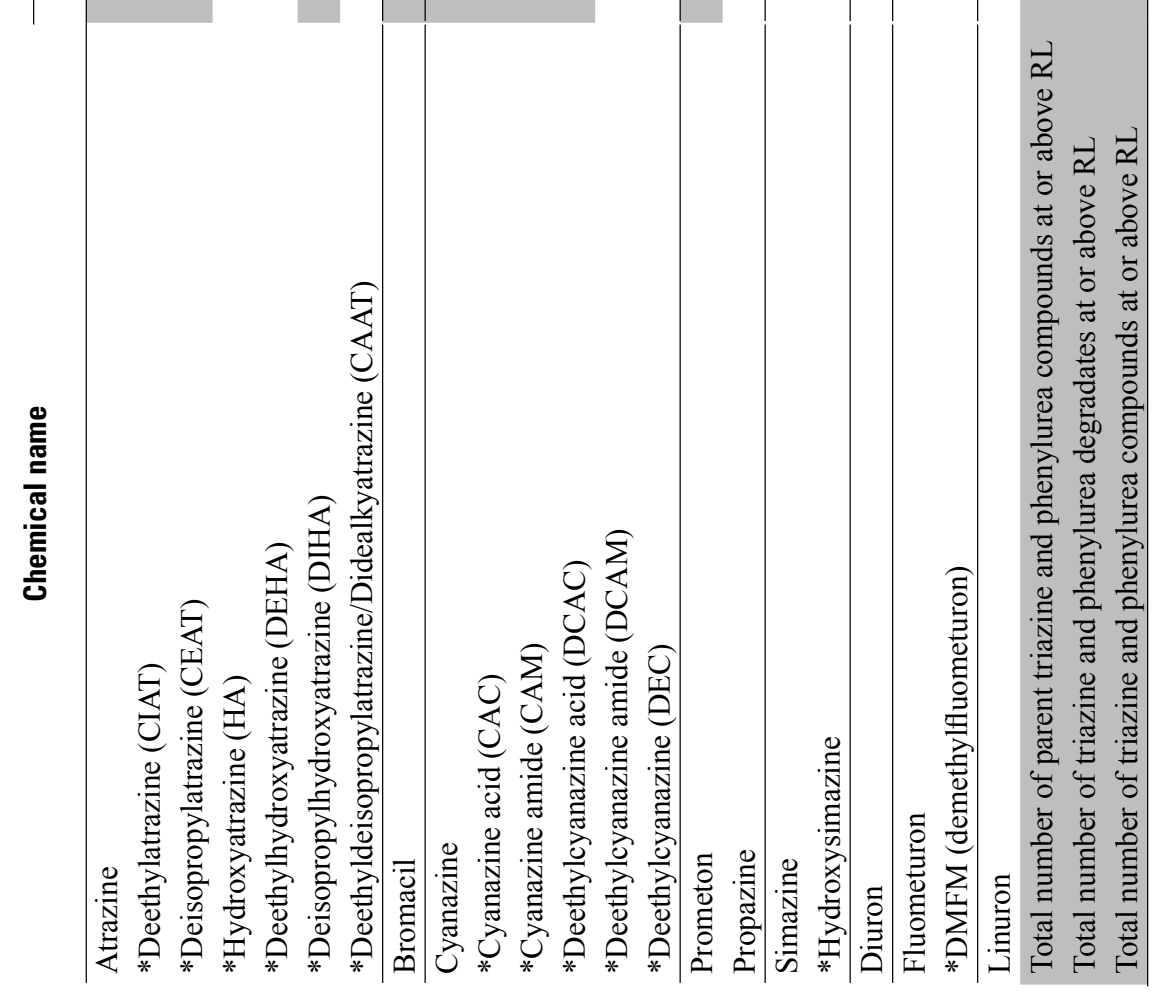


were present primarily in water from the shallow zone at well BA 437. Numerous triazine degradation products were present in the waters; cyanazine and its degradation products were prevalent in the deep zone. The atrazine concentration has remained below $1 \mu \mathrm{g} / \mathrm{L}$ (table 22), the action concentration set by the PDA (appendix 4); however, the atrazine concentration in 1984 was $11 \mu \mathrm{g} / \mathrm{L}$. Alachlor concentrations (0.34 to $0.36 \mu \mathrm{g} / \mathrm{L})$ were about one half the PDA action concentration (appendix 4) and up to five alachlor degradation products were present with concentrations ranging from about 0.02 to nearly $4 \mu \mathrm{g} / \mathrm{L}$ in the shallow and deep zones. The $20 \mu \mathrm{g} / \mathrm{L}$ of metolachlor in the composite sample collected on September 7, 2005, is consistent with results since 1997 (see fig. 20). Metolachlor concentrations were $18 \mu \mathrm{g} / \mathrm{L}$ in the shallow zone and $6.57 \mu \mathrm{g} / \mathrm{L}$ in the deep zone. The concentrations of metolachlor degradation products were nearly identical in the shallow and deep zones.

BA 642, a rural domestic well considered "upgradient" of the hot spot on the basis of the location and relative concentration of nitrate and pesticides, is one of the deepest wells but had the highest concentration of chloride $(270 \mathrm{mg} / \mathrm{L})$ of the five wells sampled. The $\mathrm{Cl}: \mathrm{Br}$ value near 5,000 indicates a halite mineral in the aquifer or road salt as possible sources of the chloride and bromide. Although relatively low in concentration, atrazine and four triazine degradation products were reported (table 31) along with acetamide degradation products of alachlor and metolachlor. BA 642 well water has the lowest measured concentrations of pesticides in the vicinity of well BA 437.

At BA 643, atrazine, alachlor, and bromacil are present in water at concentrations nearly double the concentrations in water from well BA 437 (tables 30 and 31). The historical use of well BA 643 to supply water for a commercial pesticide mixing facility may indicate a potential source for the alachlor, atrazine, and bromacil in ground water; however, the concentration of metolachlor below reporting levels in BA 643 well water is confounding. With a measured total depth of $330 \mathrm{ft}$, well BA 643 is the deepest of the wells sampled. Little is known about the construction of well BA 643 or the depth and nature of water-bearing zones to the well.

Wells BA 644 and BA 645 are north of well BA 437 along the simulated line of northward ground-water flow towards well BA 332 (Lindsey and Koch, 2004). The concentrations of pesticides in these wells are intermediate between the hot spot area and well BA 332. Well BA 644 has the same set of parent pesticides and degradation products, although at lower concentrations, as those observed at well BA 437. The nitrate concentration in well BA 644 is relatively low and suggests a possible connection to a fracture system that intersects well BA 642.

The borehole investigation at well BA 437 underscores the complex nature of the fractured carbonate-rock aquifers in the vicinity. The directions and rates of ground-water flow are not well characterized in this area. Additional hydrogeologic measurements and water-quality sampling are required to yield more insight into the occurrence of pesticides, nitrate, and chloride in this complex flow system.

The pesticide concentrations in well BA 437 or in neighboring wells sampled do not exceed USEPA health advisories (U.S. Environmental Protection Agency, 2006, 2008). No USEPA MCLs or health advisories currently exist for degradation products and for combinations of pesticides and pesticide degradation products.

\section{Lancaster County, Earl Township}

In June 2006, well LN 1842, four wells used for farmyard, livestock, and rural domestic purposes at neighboring residences, and a production well for the Borough of New Holland were sampled (table 3, fig. 26). Results of the analyses of ground-water samples are summarized in tables 32,33 , and 34 .

The pesticide compounds in ground water from well LN 1842 were primarily acetamide compounds (dominated by metolachlor) with lesser concentrations of triazine herbicides. The presence of degradation products indicates the degradation of metolachlor, alachlor, and acetochlor parent compounds is occurring. The concentrations of selected degradation products of alachlor and acetochlor exceeded the concentration of parent compounds. The alachlor concentration in water from well LN 1842 was $2.8 \mu \mathrm{g} / \mathrm{L}$ in 1991 (Durlin and Schaffstall, 1993, p. 307), which triggered the hot-spot status for the well. The sum of concentrations of alachlor degradation products and parent compounds averaged for the two June 2006 samples from well LN 1842 (0.0109 micromoles per liter $[\mu \mathrm{M} / \mathrm{L}])$ was about equal to the historic concentration of alachlor alone $(0.0104 \mu \mathrm{M} / \mathrm{L})$. In the June 2006 samples, the combined concentration of metolachlor degradation products is to about $0.07 \mu \mathrm{M} / \mathrm{L}$ (or about $20 \mu \mathrm{g} / \mathrm{L}$ ), one third of the $0.21 \mu \mathrm{M} / \mathrm{L}$ concentration of the metolachlor parent compound (about $60 \mu \mathrm{g} / \mathrm{L}$ ) (table 33). The newly proposed "ambient water-quality human-health criteria" for metolachlor is $69 \mu \mathrm{g} / \mathrm{L}$ (Pennsylvania Department of Environmental Protection, 2008).

Wells neighboring well LN 1842 were chosen for sampling in an attempt to represent three possible components of the ground-water flow system in the carbonate-rock aquifers of Cambrian age underlying Earl Township and the Borough of New Holland. The first component was deep flow discharging as pumpage from the municipal wells at the north side of New Holland (fig. 26). Well LN 1291 was sampled to represent this discharge area. The second component was flow towards the southeast and Mill Creek, which represents another possible discharge point for ground water. This component was represented by wells LN 2118 and LN 2119. The third component of flow was along the axis of an anticlinal rock structure striking approximately east-west near well LN 1842. Well LN 2000 was along the axial strike to the east. Well LN 1998 was chosen to represent a plausible upgradient location in the flow system. 
All well-water samples had reported concentrations of nitrate and pesticides. Nitrate concentration was above $10 \mathrm{mg} / \mathrm{L}$ as $\mathrm{N}$ in samples from wells along the southeast and axial east flow components. Nitrate was lowest in the samples from wells LN 1998 and LN 1291 with concentrations of 7.6 and $4.3 \mathrm{mg} / \mathrm{L}$, respectively (table 32 ). Pesticide occurrence was dominated by acetamide degradation products (table 33); however, wells LN 2118 and LN 2119 had a higher number of triazine degradation products than the other neighboring wells (table 34). The four triazine degradation products in samples from wells LN 2118 and LN 2119 were among the seven triazine degradation products reported in samples from the hot-spot well LN 1842. Water samples from well LN 2119 appear to have the same set of pesticide compounds as well LN 1842 except the acetochlor group in LN 1842 sample water was not present in well LN 2119 or the other wells (tables 33 and 34). The flow component to the discharge point at the New Holland supply well (LN 1291) has atrazine and one degradation product each of atrazine and metolachlor in ground water at concentrations of 0.03 to $0.05 \mu \mathrm{g} / \mathrm{L}$. These concentrations are nearly an order of magnitude less than in waters from wells LN 1998 and LN 2000.

Table 32. Summary of selected well and water-quality characteristics with associated numbers of pesticide parent compounds and numbers of pesticide degradates in water from well LN 1842 and five neighboring wells, Earl Township and Borough of New Holland, Lancaster County, Pennsylvania, June 1 through June 29, 2006.

[Water use: R, residence; L, Livestock; P, public supply. D.O., dissolved oxygen; Cl, chloride; $\mathrm{Cl}$ : $\mathrm{Br}$, mass (weight) ratio of chloride and bromide concentrations; $\mathrm{N}$, nitrogen; $\mu \mathrm{g} / \mathrm{L}$, micrograms per liter; RL, reporting level; -, no data]

\begin{tabular}{|c|c|c|c|c|c|c|c|c|c|c|c|}
\hline \multirow[b]{2}{*}{$\begin{array}{c}\text { Well number } \\
\text { (date sample } \\
\text { collected) }\end{array}$} & \multirow[b]{2}{*}{$\begin{array}{l}\text { Water } \\
\text { use }\end{array}$} & \multirow[b]{2}{*}{$\begin{array}{l}\text { Well } \\
\text { depth, } \\
\text { in feet }\end{array}$} & \multicolumn{3}{|c|}{$\begin{array}{c}\text { Concentration, } \\
\text { in milligrams per liter }\end{array}$} & \multirow[b]{2}{*}{$\mathrm{Cl}: \mathrm{Br}$} & \multicolumn{2}{|c|}{$\begin{array}{c}\text { Triazines; } \\
0.025-0.2 \mu \mathrm{g} / \mathrm{L} \\
\text { Reporting level }\end{array}$} & \multicolumn{2}{|c|}{$\begin{array}{c}\text { Acetamides; } \\
0.02-0.05 \mu \mathrm{g} / \mathrm{L} \\
\text { Reporting level }\end{array}$} & \multirow{2}{*}{$\begin{array}{c}\text { Total } \\
\text { number of } \\
\text { pesticide } \\
\text { compounds } \\
\text { at or above } \\
\text { RL }\end{array}$} \\
\hline & & & $\begin{array}{l}\text { Nitrate } \\
\text { as } \mathrm{N}\end{array}$ & D.0. & Cl & & $\begin{array}{c}\text { Number } \\
\text { of parent } \\
\text { compounds } \\
\text { at or above } \\
\text { RL }\end{array}$ & $\begin{array}{l}\text { Number of } \\
\text { degradate } \\
\text { compounds } \\
\text { at or above } \\
\text { RL }\end{array}$ & $\begin{array}{c}\text { Number } \\
\text { of parent } \\
\text { compounds } \\
\text { at or above } \\
\text { RL }\end{array}$ & $\begin{array}{c}\text { Number of } \\
\text { degradate } \\
\text { compounds } \\
\text { at or above } \\
\text { RL }\end{array}$ & \\
\hline LN 1842 (6/29/06) & $\mathrm{R}, \mathrm{L}$ & 65 & 32.1 & 8.3 & 44 & 1,222 & 4 & 6 & 3 & 12 & 25 \\
\hline LN $1291^{1}(6 / 5 / 06)$ & $\mathrm{P}$ & 232 & 4.3 & 4.6 & 32 & 1,000 & 1 & 1 & 0 & 1 & 3 \\
\hline LN 1998 (6/6/06) & $\mathrm{R}$ & 60 & 7.6 & .2 & 54 & 2,700 & 1 & 2 & 0 & 3 & 6 \\
\hline LN 2000 (6/1/06) & $\mathrm{R}, \mathrm{L}$ & 120 & 14.8 & 6.9 & 4.2 & 210 & 0 & 1 & 1 & 3 & 5 \\
\hline
\end{tabular}

${ }^{1}$ Production well for Borough of New Holland, Pa. 


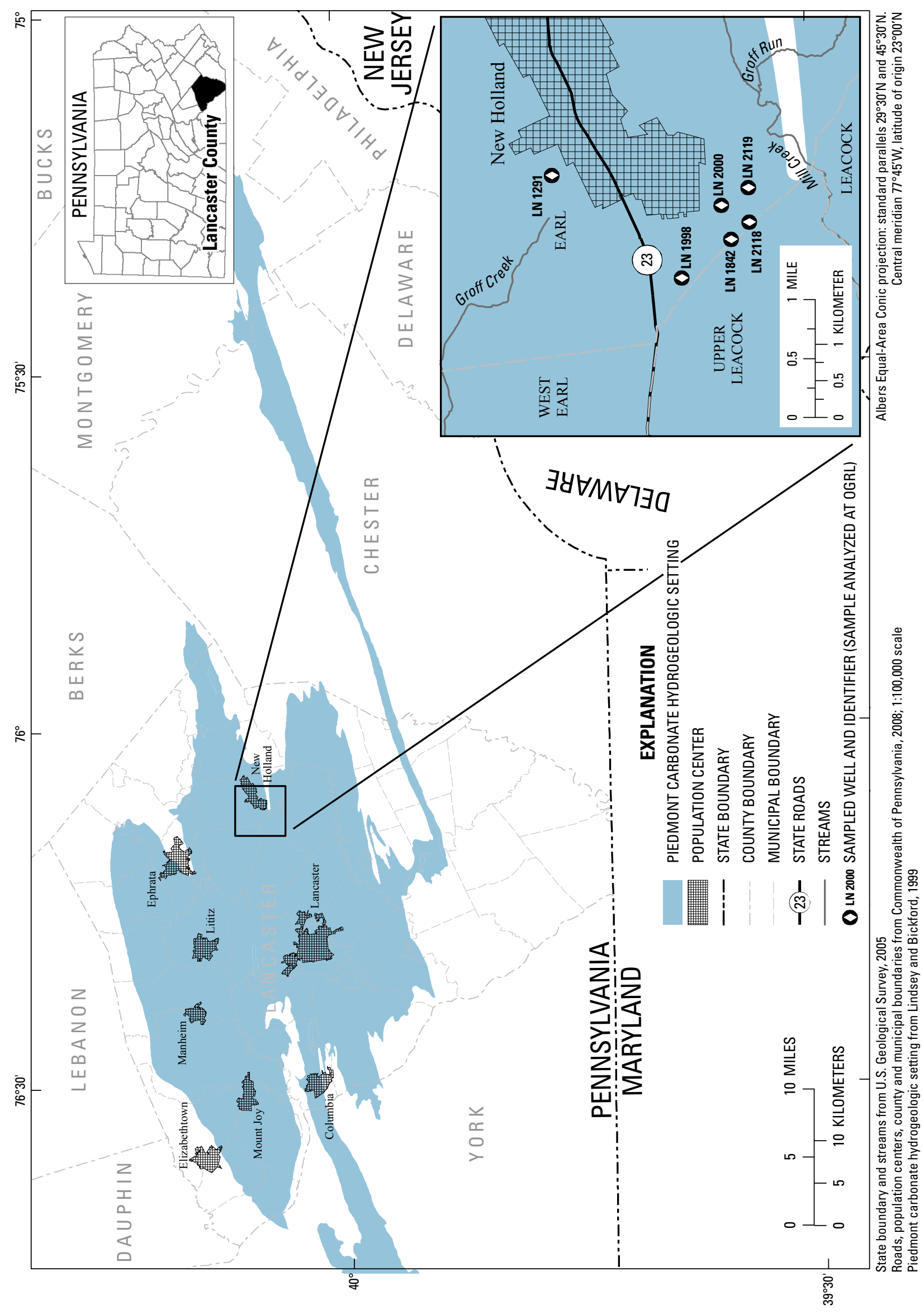

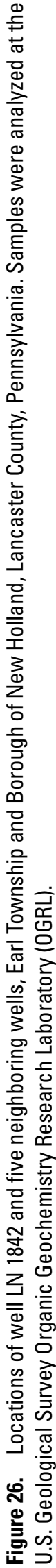



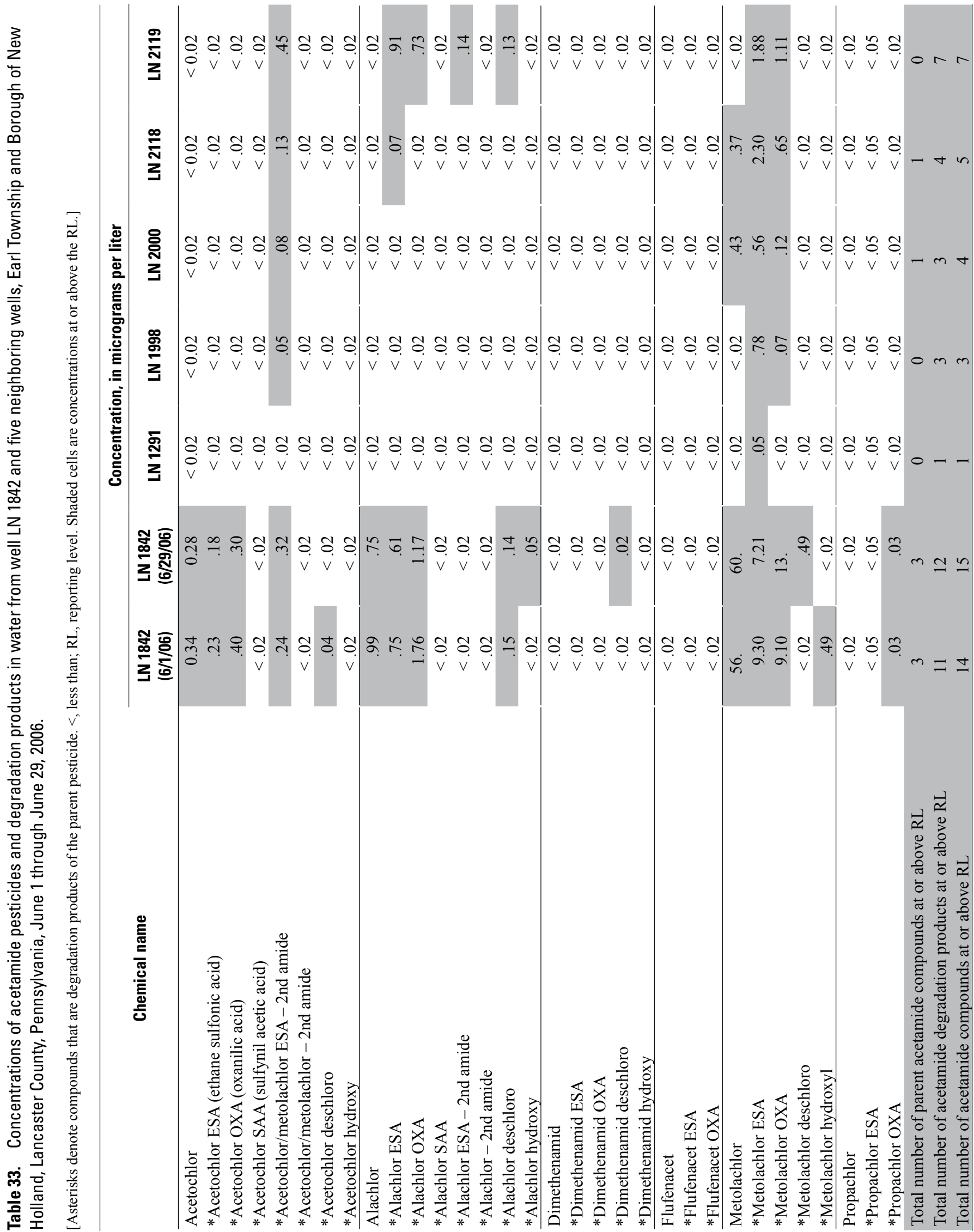


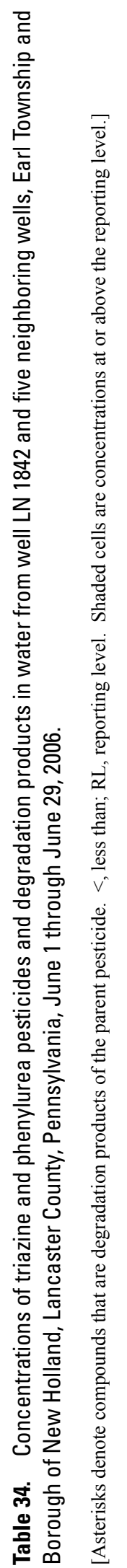

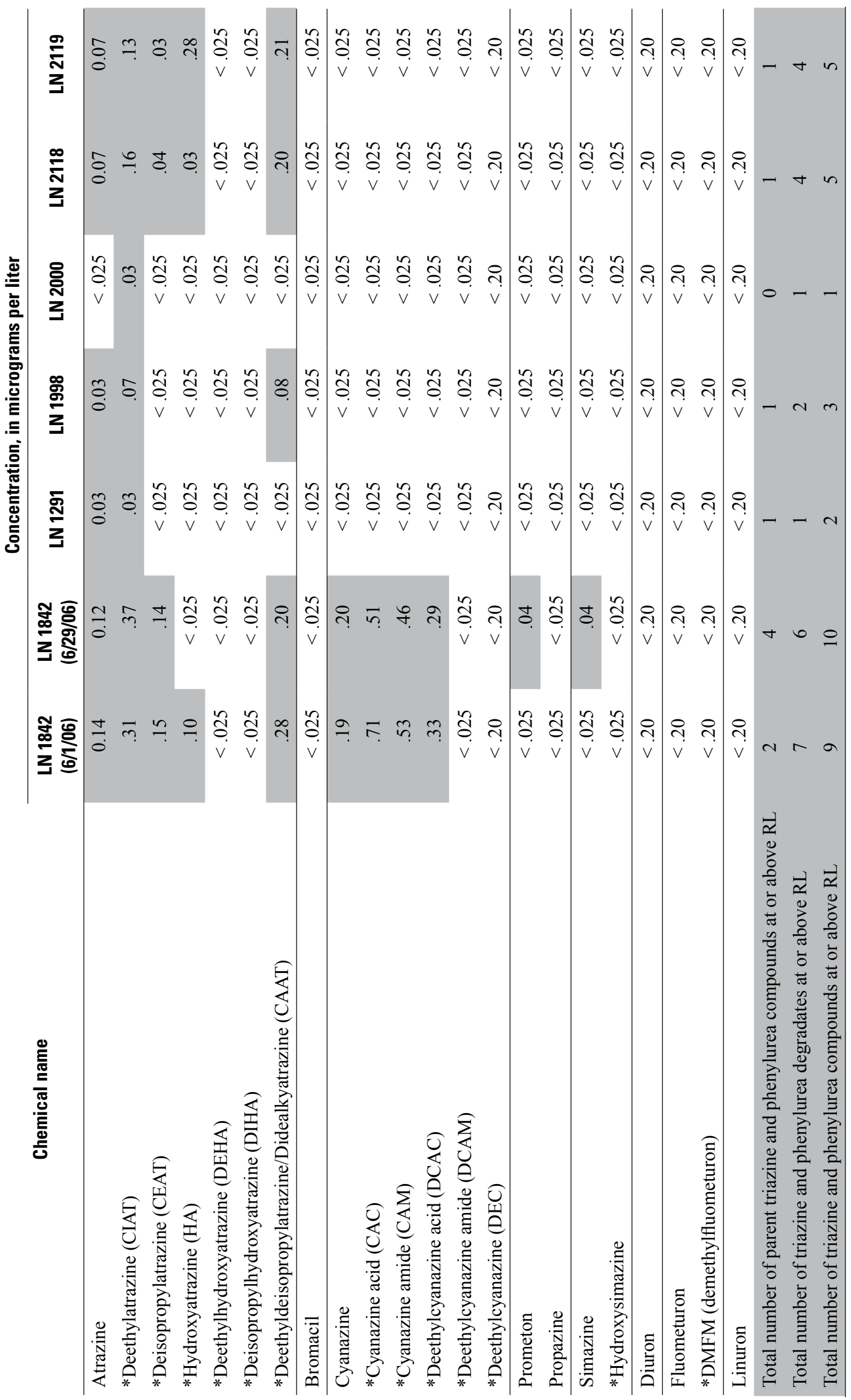




\section{Summary and Conclusions}

This report was prepared by the U.S. Geological Survey (USGS) in cooperation with the Pennsylvania Department of Agriculture (PDA) to evaluate the occurrence of pesticides in ground water as part of the Pennsylvania Pesticides and Ground Water Strategy (PPGWS). Overall, the major findings reported herein are:

- EVALUATING OCCURRENCE AND TRENDS OF PESTICIDES IN GROUND WATER REQUIRED LABORATORY METHODS CAPABLE OF MEASURING SMALL CONCENTRATIONS-

Pesticide concentrations in ground water are small enough that monitoring for and comparing pesticide concentrations in ground waters in several hydrogeologic settings required the use of consistent laboratory methods that reported a common set of pesticide compounds at minimum reporting levels (MRLs) that were less than 0.05 micrograms per liter $(\mu \mathrm{g} / \mathrm{L})$ and were supported by extensive quality assurance (QA). These attributes allowed for evaluation of concentrations among settings and over time. Analytical methods developed and used by USGS laboratories and the resulting data were a critical first step in evaluating occurrence and trends in pesticide concentrations.

- Co-ocCuRRENCE of PESTICIDES WAS COMMON-

In at least 50 percent of well samples with pesticides, multiple pesticides were detected; however, many concentrations were less than $0.01 \mu \mathrm{g} / \mathrm{L}$. Atrazine was the pesticide most reported in ground water. Commonly, deethylatrazine (CIAT) co-occurred with atrazine. Metolachlor and (or) simazine, although rare in occurrence, were the only other compounds to co-occur with atrazine in four of the five hydrogeologic settings.

- Pesticide-degradation products exhibited Co-occurRENCE WITH PARENT PESTICIDE COMPOUNDS-

Pesticide-degradation products were detected with parent compounds often at concentrations greater than the parent compounds. Analyzing for pesticide degradation products along with the parent compounds would be an important component of a comprehensive monitoring strategy for pesticides in ground water.

\section{- Monitoring SINCE 2003 HaS SHOWN NO EXCEEDANCES} OF MAXIMUM CONTAMINANT OR HEALTH ADVISORY LEVELS (MCLS OR LHAS) FOR PESTICIDES IN GROUND WATERAssessment of newly collected (2003 and 2005-07) monitoring data for pesticide concentrations in ground water from four hydrogeologic settings previously unassessed or assessed to a limited extent in baseline assessment and special-protection areas and extensive QA data for pesticides shows the MCLs and LHAs were not exceeded.
- THE NUMBER OF PESTICIDES IN GROUND WATER, THE MAGNITUDE OF THE CONCENTRATIONS, AND THE SPATIAL PATTERNS OF OCCURRENCE HAVE SHOWN DISTINCT VARIATIONS AMONG THE FIVE HYDROGEOLOGIC SETTINGS-

Widespread occurrence patterns, with pesticides at measurable concentrations in waters from over 50 percent of wells sampled, characterized the Devonian-Silurian carbonate and Northeastern Glaciated surficial settings. The carbonate setting, with a median atrazine concentration five times larger than the glaciated surficial setting, was the more vulnerable of the two. In contrast, a localized occurrence pattern with pesticides at measurable concentrations in waters from 20 percent of wells sampled, characterized the Great Valley siliciclastic setting with a median atrazine concentration similar to the glaciated surficial setting and five times lower than the carbonate setting. This supports earlier studies that identified carbonate settings as the most vulnerable for pesticide contamination of ground water.

- NitRate CONCENTRATION TESTING SHOWED SOME PROMISE AS A WAY TO PRIORITIZE WELL SAMPLES FOR PESTICIDE ANALYSES-

Relatively inexpensive test results for nitrate correlated directly with the number of pesticides above the MRLs in the Devonian-Silurian carbonate setting and with atrazine concentrations in the Devonian-Silurian carbonate and the Great Valley siliciclastic settings. Accordingly, elevated nitrate results from wells in these two settings could be used to prioritize wells selected for future sample collection for pesticide analyses.

- Preliminary testing for trends in pesticide ConcenTRATIONS INDICATES A DECLINE IN CONCENTRATION FOR ATRAZINE BUT NO CHANGE FOR METOLACHLOR IN GROUND WATER-

In carbonate settings known to be vulnerable to pesticide contamination, initial results on changes in pesticide concentrations in 2003 compared to 1993-95 showed waters from nine wells sampled twice having lower atrazine concentrations in 2003.

- MoNitoring IN THREE AREAS OF SPECIAL GROUND-WATER PROTECTION LED TO IMPROVED UNDERSTANDING OF PESTICIDE OCCURRENCE IN THE VICINITY OF HOT-SPOT WELLSSamples from wells neighboring the hot-spot wells showed the same sets of pesticides as the hot-spot wells. Concentrations at or in the vicinity of hot-spot wells BA 437 and LN 1842 qualified for continued monitoring as part of the PPGWS.

Details of the findings are presented below. Subheadings developed from the main scope elements and sections of this report are used to organize the summary material. 


\section{Changing Patterns of Pesticide Use Related to Land-Use Changes}

Agricultural pesticide use was estimated using application-rate and crop-acreage data; atrazine and metolachlor, with $1,314,000$ and $895,000 \mathrm{lb} / \mathrm{yr}$, respectively, were the most heavily used agricultural pesticides statewide in 2004-05. Atrazine and metolachlor were used predominantly on corn crops. On the basis of statewide pesticide-use data for corn, atrazine use decreased and metolachlor/S-metolachlor use increased in 2004-05 (2004 data were for field corn and 2005 data were for sweet corn) compared to 1996 (field corn and sweet corn data were combined). Counties where agricultural lands are predominant make up a large fraction of the total use of pesticides; Lancaster County had the greatest amounts of use for 1996 and 2004-05, followed by York, Franklin, and Berks Counties. Of 66 counties statewide, these four counties accounted for atrazine and metolachlor use in 2004-05 of 360,000 and $236,000 \mathrm{lb} / \mathrm{yr}$, respectively. To explain changes in agricultural pesticide use, changes in forest, agriculture, and urban land covers were evaluated in nine major hydrogeologic settings using the National Land Cover Database (NLCD) 1992 and NLCD 2001. A comparison of 1992 county data and 2001 county data showed decreases of agricultural land up to 12 percent (median decrease 7.2 percent), decreases of forested land up to 10 percent (median decrease 4.5 percent), and a corresponding increase of urban land up to 11 percent (median increase 2 percent).

\section{Investigations of Pesticides in Pennsylvania Ground Water, 1997-2002}

A retrospective summary of investigations of pesticides in Pennsylvania ground water through 1998 compiled in an earlier study documented that five of the nine hydrogeologic settings identified as vulnerable to pesticide contamination had inadequate monitoring data for the PPGWS. An updated retrospective through 2002 added six new data sources from previous USGS investigations and identified a data gap in the five hydrogeologic settings; filling this data gap was the impetus for the 2003-07 data-collection efforts in the baselineassessment areas.

\section{Quality Assurance and Quality Control}

Quality-control (QC) analyses of representativeness of sampling in the hydrogeologic settings, false positives, false negatives, and bias and variability in results for pesticides, nitrate, nitrite, total coliform, and E. coli bacteria were used to qualify the data from the Pennsylvania Department of Environmental Protection Laboratory (PADEPL), the USGS National Water Quality Laboratory (NWQL), and the USGS Organic Geochemistry Research Laboratory (OGRL). Results of these analyses indicated 1) waters sampled were considered representative of the aquifers sampled because site-selection criteria combined with stability criteria for field measurements were met 75 to 100 percent of the time; 2) false positives were not a problem in most cases - sampling procedures, sample equipment and containers, cleaning procedures, and analytical processes were not contributing contamination bias to samples; 3) false negatives (spiked compounds not reported) were less than 5 percent; and 4) bias in recovery and variability varied by compound and laboratory used for pesticides, were excellent for nitrate and nitrite, and could not be adequately evaluated for bacteria because of the methodology used.

Biases in recovery and variability for pesticides were determined from field-spiked reagent water (FSRW) or labreagent-spiked (LRS) water samples; selected pesticide results were 'qualified' where QA objectives for bias (recovery within \pm 25 percent of the true value) and variability (replicate results within \pm 25 percent of each other) were not met. The effects of matrix environmental water on recoveries were not evaluated during this study. Reported recoveries of the qualified compounds should be interpreted with the ground-water results because of the potential for 1) actual concentrations to be higher or lower than reported or 2) false negatives. The qualified compounds by laboratory are as follows:

- PADEPL-Azinphos-methyl, captan, fenpropathrin, hexachlorocyclopentadiene, metribuzin, and phosmet results were qualified on the basis of the results of six to nine field QC samples and (or) internally submitted QC samples. No reported concentrations in environmental samples were above the respective minimum reporting levels (MRLs) for any of these seven compounds when analyzed by thePADEPL, and it is possible, therefore, that some of the results reported as less than the MRLs are actually false negatives.

- USGS NWQL-Of the 107 pesticide compounds analyzed at the NWQL, results for 48 compounds did not meet QA objectives. Qualified compounds include those 39 compounds identified from internal NWQL QC as "estimated," 4 compounds qualified as a result of 33 field QC samples (ethalfluralin, metribuzin, p,p'-DDE, and propargite), and 5 additional compounds (2,4-DB, bendiocarb, clopyralid, $\mathrm{MCPB}$, and sulfometuron-methyl) that were not qualified as estimated in 2003 but had NWQL QC results (LRS) that did not meet study QA objectives. Of the 48 compounds, deethylatrazine (CIAT) was reported above the MRL in 81 samples. Ten or fewer samples had reported concentrations of terbacil, carbofuran, carbaryl, benomyl, deisopropylatrazine (CEAT), deethyldeisopropylatrazine (CAAT), dinoseb, norflurazon, and sulfometuron-methyl. The remaining qualified compounds were not reported at, above, or below the MRLs in any of the samples analyzed; it is possible that some of the results are actually false negatives. 
- USGS OGRL - Of the 54 pesticide compounds analyzed at the OGRL, bias and variability were evaluated for acetochlor, alachlor, atrazine, cyanazine, CIAT, linuron, metolachlor, propachlor, prometon, and simazine in field QC samples. All compounds but linuron met study QA goals for variability, and all compounds but atrazine, prometon, simazine, and CIAT met study QA goals for bias. Linuron was not detected above the MRL; however, atrazine, prometon, simazine, and CIAT were detected above the respective MRLs. Linuron, atrazine, prometon, simazine, and CIAT results are noted as not meeting study QA goals but were not qualified because of the low numbers of field QC samples and the lack of long-term QC results that could be used for comparison.

\section{Monitoring Data for Pesticide Occurrence, 2003-07}

A total of 126 wells were monitored for pesticides, nitrate, nitrite, and most probable numbers of total coliform and E. coli bacteria for the baseline assessment of five hydrogeologic settings previously unassessed or assessed to a limited extent. Between 20 and 30 wells per setting were sampled in the following hydrogeologic settings: Blue Ridge crystalline and Triassic Lowland siliciclastic, Eastern Lake surficial, Devonian-Silurian carbonate, Great Valley siliciclastic, and Northeastern Glaciated surficial. Of the 126 well waters analyzed, 43 had concentrations of one or more pesticides above the respective MRLs or estimated below the MRLs. All reported concentrations from 15 of these 43 wells were estimated below the MRL or estimated because of unacceptable bias in recovery and (or) variability. Well samples with one or more estimated pesticide concentrations were analyzed at the NWQL; the majority of these wells were in the Northeastern Glaciated surficial hydrogeologic setting ( 9 wells), followed by the Great Valley siliciclastic ( 3 wells), the Blue Ridge crystalline and Triassic Lowland siliciclastic ( 2 wells), and the Devonian-Silurian carbonate (1 well) settings. Occurrence of pesticides varied by setting. In terms of laboratory used and total number of wells sampled per setting, the number of well waters with reported concentrations (above the MRLs or estimated below the MRLs) was: Blue Ridge crystalline and Traissic Lowland (NWQL -6 of 10 wells; PADEPL -0 of 10 wells), Eastern Lake surficial (PADEPL — 0 of 20 wells), Devonian-Silurian carbonate (NWQL-16 of 28 wells), Great Valley siliciclastic (NWQL -5 of 30 wells), and Northeastern Glaciated surficial (NWQL-16 of 28 wells). At the PADEPL, at least 19 pesticide compounds were analyzed at MRLs of 0.10 to $1.6 \mu \mathrm{g} / \mathrm{L}$; at the NWQL, at least 52 pesticide compounds were analyzed at MRLs of 0.002 to $1.5 \mu \mathrm{g} / \mathrm{L}$. No pesticide concentration in samples collected in the five hydrogeologic settings exceeded the USEPA maximum contaminant levels (MCLs) or PPGWS action levels, although the pesticide results in the Eastern Lake surficial and sections of the Blue
Ridge crystalline and Triassic Lowland siliciclastic hydrogeologic settings (samples analyzed at the PADEPL) can not be directly compared with the pesticide results in the DevonianSilurian carbonate, Great Valley siliciclastic, and Northeastern Glaciated surficial hydrogeologic settings (samples analyzed at the NWQL) because of the analytical differences for the two laboratories.

Opportunities to evaluate co-occurrence of pesticides in well water sampled varied by year because of the differences in the number and respective MRLs of the pesticides analyzed at the PADEPL and the NWQL. Co-occurrence of pesticides was common (50 to 100 percent) in well samples, but many concentrations were at estimated levels; metolachlor and (or) simazine co-occurred with atrazine, and frequently CIAT, in one or more well-water samples in the following hydrogeologic settings: Blue Ridge crystalline and Triassic Lowland siliciclastic, the Devonian-Silurian carbonate, the Great Valley siliciclastic, and the Northeastern Glaciated surficial. Only one concentration of simazine $(0.151 \mu \mathrm{g} / \mathrm{L})$ was above $0.10 \mu \mathrm{g} / \mathrm{L}$.

Statistical-correlation analysis, using the NWQL analytical results, was used to investigate the strength of the relations between pesticide occurrence and two indicators of waterquality degradation - occurrence of total coliform bacteria and nitrate concentration. The results of a $2 \times 2$ contingencytable test showed a significant relation between presence or absence of atrazine or metolachlor and presence or absence of total coliform bacteria only for the 10 wells representing the Blue Ridge crystalline and Triassic Lowland siliciclastic setting. The Eastern Lake surficial setting was excluded from testing because none of the 20 samples from the setting were analyzed at the NWQL. Therefore, although bacteria were commonly found in samples of well water, statistical testing indicated bacteria in well water were not a significant indicator of the presence of pesticides, and bacteria results could not be used to prioritize selection of wells for pesticide analyses. Spearman's rank-test correlations were done using pesticide and nitrogen results in the following hydrogeologic settings: Devonian-Silurian carbonate, the Great Valley siliciclastic, and the Northeastern Glaciated surficial. Results suggest that a direct correlation exists between nitrate concentration and the number of pesticides above the MRLs in the Devonian-Silurian carbonate setting and between nitrate and atrazine concentrations in the Devonian-Silurian carbonate and the Great Valley siliciclastic settings. Accordingly, elevated nitrate results from wells in these two settings could be used to prioritize wells selected for future sample collection for pesticide analyses. The pesticide results from the Blue Ridge crystalline and Triassic Lowland siliciclastic and the Eastern Lake surficial settings were not included in these statistical tests because of the MRL differences in all or part of these data sets where samples were analyzed at the PADEPL. Therefore, for future monitoring that involves comparison of pesticide concentrations in ground waters in several hydrogeologic settings, the use of a consistent set of laboratory methods and reporting a consistent set of pesticide compounds at MRLs less than 
$0.05 \mu \mathrm{g} / \mathrm{L}$ is essential for evaluation of concentrations among settings and over time.

\section{Patterns of Pesticide Concentration Change, 1993-2004}

Changes in pesticide concentrations were evaluated for 18 wells sampled twice during the decade 1993-2004 in the Appalachian Mountain carbonate, Triassic Lowland siliciclastic, Great Valley carbonate, and Piedmont carbonate hydrogeologic settings. Nine of the 18 wells were chosen for further analysis because the NWQL was used consistently for analyses of the pairs of samples. Pesticides reported in the initial sample from each well in the mid-1990s were generally still present in samples collected in 2003 but at lower concentrations. Two nonparametric statistical analyses, the Kruskal-Wallis and Tukey-Kramer tests, were used to determine if there were statistically significant correlations between atrazine and metolachlor concentrations and a categorical 'date' variable for the nine wells. These tests indicated significantly lower median concentrations of atrazine in the samples collected during 2003 than during 1993-95; however, significant changes in the median concentrations of metolachlor were not observed between the sample dates. The Wilcoxon signed-rank test also was used to test for temporal changes in median concentrations for atrazine and metolachlor using differences in paired-observation data (1993, 1994, or 1995 and 2003) for the nine baseline-assessment wells. Results from this test showed a significant decrease in atrazine concentration but did not identify a significant temporal change in metolachlor concentration. For the nine wells, a comparison of changes in concentration of atrazine and its degradation product CIAT to changes in water levels and land-use practices indicated that higher water levels, decreases in agricultural land use, and decreases in atrazine application in 2003 compared to 1993-95 could all be factors in the decreased concentrations observed.

\section{Pesticides in Ground Waters Representing Three Areas of Special Ground-Water Protection}

At three pesticide hot-spot wells (wells BA 437, LN 1842, and BE 1370 in areas of special ground-water protection), changes in concentration of parent pesticide compounds and the co-occurrence of pesticide-degradation products with parent compounds in ground water were evaluated. During exploratory data analysis, scatterplots and boxplots were used to analyze the data graphically; the Kruskal-Wallis and Tukey-Kramer tests were used as screening tools to examine for significant seasonality and to determine which seasonal groups differed from each other but did not account for trend over time. These exploratory statistical tests indicated seasonality was likely a factor for well BA 437 ; significantly higher median concentrations of alachlor were observed at BA 437 during the fall than during the winter. During trend testing, seasonality was observed at all three hot-spot wells.

Nonparametric statistical analyses were used to determine monotonic trends in pesticide and nitrate concentration data at the three hot-spot wells using a 5-year (2003-07) data set and a long-term data set (dates varied). Trends in concentrations of alachlor, atrazine, metolachlor, and nitrate from wells BA 437 and LN 1842 were analyzed with the Mann-Kendall (overall trend) and Seasonal Kendall trend tests with a p-value of 0.05. Acetochlor concentrations in well LN 1842 also were analyzed using the same data sets and trend tests mentioned above. Acetochlor was not analyzed for trends at wells BA 437 or BE 1370 because of insufficient data.

At well BA 437, statistically significant downward trends were observed in results from both trend tests in the long-term data set for atrazine and in the 5-year data set for nitrate. These trends indicate improvements in water quality.

At well LN 1842, alachlor was the only pesticide that had statistically significant downward trends in concentration for both the 5-year and long-term data sets. Atrazine had a significant downward trend in concentrations only in the longterm data set, and a downward trend was observed for nitrate only in the 5-year data set. Metolachlor showed a downward trend using the Mann-Kendall test for the 5-year data set even though a downward trend for metolachlor was not observed in the 5-year data set at a 0.05 significance level ( $\mathrm{p}$ equal to 0.05 or less) using the Seasonal Kendall trend test. Metolachlor had the most dramatic decrease in concentrations evaluated for trends at well LN 1842 using the 2003-07 data set - approximately $65 \mu \mathrm{g} / \mathrm{L}$. Overall, the downward trends observed in well LN 1842 indicated improvements in water quality.

At well BE 1370, the 5-year data (2003-07) were analyzed using the Mann-Kendall trend test only; the number of samples was insufficient to analyze for trend using the Seasonal Kendall trend test. The results of the Mann-Kendall trend test indicated concentrations of metolachlor had significant downward trends in 2003-07, but concentrations of alachlor, atrazine, and nitrate had no significant trends. The longterm data set for well BE 1370 was analyzed for trends with the Mann-Kendall and Seasonal Kendall trend tests (p-value equal to 0.05 or less); significant downward trends were observed in alachlor, atrazine, and metolachlor. The 5-year and long-term data sets for well BE 1370 had high percentages of censored (less-than) values for alachlor and atrazine, and trend results for these two compounds are less certain. As observed for wells BA 437 and LN 1842, the downward trends in pesticide concentration in well BE 1370 indicated improvements in water quality.

Testing for homogeneity of trend was done on the longterm data sets to evaluate seasonal differences in pesticide concentrations that would not be apparent using the tests for trend that assume a single pattern of trend across all seasons. Results of these analyses showed that the downward trend for atrazine at well BA 437 was due entirely to a significant downward trend in the summer. The homogeneity of trend test also indicated a downward trend for alachlor concentrations 
in the summer in well BA 437; however, the trend was weak because the results from the Seasonal Kendall trend test indicated no trend. At well LN 1842, the downward trend in alachlor was due to statistically significant downward trends in the summer and fall, but for atrazine, the downward trend was due to statistically significant downward trends in the spring and fall. Finally, the homogeneity of trend test indicated that the downward trends in the long-term data set for atrazine and metolachlor in well BE 1370 were entirely due to significant downward trends in the winter samples, and the downward trends in the long-term data for alachlor were the result of significant downward trends in the winter and spring.

Additional sampling near the three hot-spot wells, BE 1370, BA 437, and LN 1842, was conducted in 2005 and 2006 to better understand the occurrence of pesticides and pesticide degradation products in ground water and to enhance monitoring in areas of special ground-water protection. To understand the extent of natural breakdown of the pesticides, parent pesticides and their degradation products were analyzed. A total of 16 sites (15 wells and 1 spring) in addition to the three hot-spot wells were sampled one time to characterize the distribution of 15 pesticides, 39 pesticide degradation products, and other water-quality indicators, such as bromide, chloride, and nitrate. Pesticide occurrence in water from wells in all three areas of special ground-water protection was highly variable, but no pesticide concentrations exceeded current USEPA MCLs or lifetime health advisories (LHAs).

Near well BE 1370, pesticides present in the hot-spot well also were present in the five neighboring wells tested (BE 1775, BE 1298, BE 1776, BE 1774, and BE 1773) and in a spring (BE SP20) on the same property as the hot-spot well. The spring and well BE 1370 both had three to four times as many degradation products as parent compounds; concentrations of parent compounds and degradation products were similar. Acetamide degradation products were more common than the triazine and phenylurea degradation products at all wells, except BE 1775.

At well BA 437, a shallow water-bearing zone at $43-48 \mathrm{ft}$ below land surface supplied most of the water to the well, and a deeper water-bearing zone at $68-99 \mathrm{ft}$ was only a minor source of water. Pesticide parent compounds and degradation products were present in both the shallow and deep zones. Water in the shallow zone had greater concentrations of nitrate, metolachlor, alachlor, and the triazine herbicide parents than the deeper zone. Cyanazine degradates were mostly in the deep zone, and the shallow zone had more alachlor degradates than the deep zone. Degradates of metolachlor had similar concentrations in the deep and shallow zones.

Near well BA 437, the same sets of pesticides in the hotspot well were present in select wells of the five neighboring wells tested (BA 642, BA 643, BA 644, BA 645, and BA 332). Water from well BA 643 had concentrations of atrazine, alachlor, and bromacil nearly double the concentrations measured in well BA 437. All neighboring wells sampled had reported concentrations of one or more pesticide parents and degradation products in well water. The samples collected from wells BA 643 and BA 644 each had 24 pesticide compounds (parent and degrades combined), which were comparable to that reported from hot-spot well BA 437. The production well (BA 332) had reported concentrations of nine pesticide compounds - the maximum concentration of these compounds was for metolachlor ethane sulfonic acid (ESA) $(1.27 \mu \mathrm{g} / \mathrm{L})$. For four of the five neighboring wells, nitrate concentrations ranged from 1.1 to $11.7 \mathrm{mg} / \mathrm{L}$ as N. For BA 643, the nitrate concentration was $64 \mathrm{mg} / \mathrm{L}$ as N, which was similar to the concentration at the hot-spot well $(66 \mathrm{mg} / \mathrm{L}$ as $\mathrm{N})$.

At well LN 1842, pesticides in water were primarily acetamide compounds dominated by metolachlor. Five wells neighboring LN 1842 (LN 1291, LN 2118, LN 2119, LN 1998, and LN 2000) had measured concentrations for one or more pesticide parents and degradates; the number of degradates was greater than the number of parent compounds in most samples. Pesticide occurrence in the five wells was also dominated by acetamide degradation products - up to a maximum number of seven degradates in well LN 2119; however, wells LN 2118 and LN 2119 had a higher number (4) of triazine degradation products than the other wells. One degradate of acetochlor was measured in four of the neighboring wells. Supply well LN 1291 had reported concentrations of atrazine, CIAT, and metolachlor ESA, all at concentrations of $0.05 \mu \mathrm{g} / \mathrm{L}$ or less. Nitrate concentrations were less than $10 \mathrm{mg} / \mathrm{L}$ (USEPA MCL for nitrate) in water from only two neighboring wellsLN 1998 and LN 1291.

Exceedances of the PPGWS action levels were assessed at the three pesticide hot-spot wells and the neighboring wells. For alachlor, the PPGWS action level of $0.66 \mu \mathrm{g} / \mathrm{L}$ was exceeded at well LN 1842 in all samples collected from 2003 to 2007, with the exception of the August 2007 sample; at well BE 1370, one sample collected in July 2004 exceeded the alachlor action level, and near well BA 437, the alachlor action level was exceeded at wells BA 643 and BA 644. For metolachlor, the PPGWS action level of $33 \mu \mathrm{g} / \mathrm{L}$ was exceeded in all samples from well LN 1842 and in four samples from well BA 437. For atrazine, the PPGWS action level of $1.0 \mu \mathrm{g} / \mathrm{L}$ was exceeded at well BA 437 (August 2003) and a neighboring well (BA 643 in September 2005). For simazine, the PPGWS action level of $1.3 \mu \mathrm{g} / \mathrm{L}$ was not exceeded. Therefore, continued monitoring of alachlor, metolachlor, and atrazine concentrations as part of the PPGWS would be needed at wells LN 1842 and near BA 437.

As part of the PPGWS, continued monitoring in the area of wells LN 1842 and BA 437 would be needed to further define the occurrence and persistence of pesticide parent compounds and degradation products, especially for wells with pesticide concentrations exceeding action levels. The occurrence of pesticide parent compounds and degradation products in well water was not limited to the three hot-spot wells summarized herein because all wells sampled near the pesticide hot spots had one or more reported concentrations of pesticides and (or) degradation products. Concentrations of some degradation products were significantly greater than concentrations of the respective parent compound. No USEPA 
MCLs or LHAs exist for pesticide degradation products or for combinations of pesticides and pesticide degradation products; therefore, the human-health effects (cancer risk, effects on human organs, etc.) of concentrations of these compounds in well water are not established.

\section{Acknowledgments}

The authors thank Donald Gilbert (PDA), Phillip Pitzer (PDA), John Tacelosky (retired PDA), and Vance Wagner (formerly with PDA) for assistance in developing and supporting the project. USGS staff David L. O'Brien, Linda F. Zarr, James E. Welch, James E. Bubb (former employee), Donald R. Williams (retired USGS), Heather L. Eggleston, Suzanne J. Ward, and Ian Orland (USGS/ National Association for Geoscience Teachers [NAGT] intern), and volunteers Albert Becher (retired USGS), Jennifer Reese, and Deborah

A. Hardman are thanked for their assistance with identification of wells that met sampling criteria and (or) their assistance with sample collection and processing. The authors also thank the following individuals for substantial contributions: geographic information system (GIS) maps for site reconnaissance and reporting, Scott A. Hoffman and Lee W. Eicholtz; editorial review and preparation of text and graphics, Kim L. Otto; colleague review, Lisa R. Fogarty (USGS Michigan Water Science Center) and David A. Eckhardt (USGS New York Water Science Center); and assistance in obtaining drillers' records, Gary Fleeger and Jody Zipperer (Pennsylvania Topographic and Geologic Survey). Finally, much gratitude is given to the well owners who allowed their wells to be sampled one or more times during the course of the project.

\section{References Cited}

American Public Health Association, American Water Works Association, and Water Pollution Control Federation, 2004, Standard methods for the analysis of water and wastewater (21st ed.): Washington, D.C., American Public Health Association, Section 9223.

Becher, A.E., 1996, Ground-water resources of Cambrian and Ordovician carbonate rocks in the Valley and Ridge Physiographic Province of Pennsylvania: U.S. Geological Survey Open-File Report 90-109, 134 p.

Bexfield, L.M., 2008, Decadal-scale changes of pesticides in ground water of the United States, 1993-2003: Journal of Environmental Quality, v. 37, p. S-226-S-239.
Breen, K.J., 2000, Quality-assurance design applied to an assessment of agricultural pesticides in ground water from carbonate bedrock aquifers in the Great Valley of eastern Pennsylvania: U.S. Geological Survey Water-Resources Investigations Report 00-4104, $31 \mathrm{p}$.

Coll, M.B., Jr., and Siwicki, R.W., 1999, Water resources data, Pennsylvania, water year 1998, vol. 3, Ohio River and St. Lawrence River Basins: U.S. Geological Survey WaterData Report PA-98-3, 352 p.

Commonwealth of Pennsylvania, 2008, Roads, population centers, county and municipal boundaries: accessed February 22, 2008, at http://www.pasda.psu.edu/.

Debrewer, L.M., Ator, S.W., and Denver, J.M., 2008, Temporal trends in nitrate and selected pesticides in Mid-Atlantic ground water: Journal of Environmental Quality, v. 37, p. S-296-S-308.

Durlin, R.R., and Schaffstall, W.P., 1993, Water resources data, Pennsylvania, water year 1992, vol. 2, Susquehanna and Potomac River Basins: U.S. Geological Survey WaterData Report PA-92-2, p. 279-337.

Durlin, R.R., and Schaffstall, W.P., 1999a, Water resources data, Pennsylvania, water year 1998, vol. 1, Delaware River Basin: U.S. Geological Survey Water-Data Report PA-98-1, $405 \mathrm{p}$.

Durlin, R.R., and Schaffstall, W.P., 1999b, Water resources data, Pennsylvania, water year 1998, vol. 2, Susquehanna and Potomac River Basins: U.S. Geological Survey Water-Data Report PA-98-2, 456 p.

Durlin, R.R., and Schaffstall, W.P., 2001, Water resources data, Pennsylvania, water year 2000, vol. 1, Delaware River Basin: U.S. Geological Survey Water-Data Report PA-00-1, $652 \mathrm{p}$.

Durlin, R.R., and Schaffstall, W.P., 2002, Water resources data, Pennsylvania, water year 2001, vol. 1, Delaware River Basin: U.S. Geological Survey Water-Data Report PA-01-1, $529 \mathrm{p}$.

Durlin, R.R., and Schaffstall, W.P., 2003, Water resources data, Pennsylvania, water year 2002, vol. 2, Susquehanna and Potomac River Basins: U.S. Geological Survey WaterData Report PA-02-2, 536 p.

Eichelberger, J.W., Munch, J.W., and Shoemaker, J.A., 1994, Determination of organic compounds in drinking water by liquid-solid extraction and capillary column gas chromatography/mass spectrometry: U.S. Environmental Protection Agency Method 525.2, 60 p. 
Fishman, M.J., ed., 1993, Methods of analysis by the U.S. Geological Survey National Water Quality LaboratoryDetermination of inorganic and organic constituents in water and fluvial sediments: U.S. Geological Survey Open-File Report 93-125, 217 p.

Furlong, E.T., Anderson, B.D., Werner, S.L., Soliven, P.P., Coffey, L.J., and Burkhardt, M.R., 2001, Methods of analysis by the U.S. Geological Survey National Water Quality Laboratory-Determination of pesticides in water by graphitized carbon-based solid-phase extraction and high-performance liquid chromatography/mass spectrometry: U.S. Geological Survey Water-Resources Investigations Report 01-4134, 73 p.

Helsel, D.R., and Hirsch, R.M., 2002, Statistical methods in water resources: U.S. Geological Survey Techniques of Water-Resources Investigations, book 4, chap. A3, 510 p.

Helsel, D.R., Mueller, D.K., and Slack, J.R., 2005, Computer program for the Kendall family of trend tests: U.S. Geological Survey Scientific Investigations Report 2005-5275, $4 \mathrm{p}$.

Hoaglin, D.C., Mosteller, F., and Tukey, J.S., 1983, Understanding robust and exploratory data analysis: New York, John Wiley and Sons, 447 p.

Kolpin, D.W., Schnoebelen, D.J., and Thurman, E.M., 2004, Degradates provide insight to spatial and temporal trends of herbicides in ground water: Ground Water, v. 42, no. 4, p. 601-608.

Kolpin, D.W., Sneck-Fahrer, D., Hallberg, G.R., and Libra, R.D., 1997, Temporal trends of selected agricultural chemicals in Iowa's groundwater, 1982-1995-Are things getting better?: Journal of Environmental Quality, v. 26, p. 1,007-1,017.

Lee, E.A., and Strahan, A.P., 2003, Methods of analysis by the U.S. Geological Survey Organic Geochemistry Research Group -Determination of acetamide herbicides and their degradation products in water using online solid-phase extraction and high-performance liquid chromatography/ mass spectrometry: U.S. Geological Survey Open-File Report 03-173, 17 p.

Lee, E.A., Strahan, A.P., and Thurman, E.M., 2002, Methods of analysis by the U.S. Geological Survey Organic Geochemistry Research Group-Determination of triazine and phenylurea herbicides and their degradation products in water using solid-phase extraction and liquid chromatography/mass spectrometry: U.S. Geological Survey OpenFile Report 02-436, 19 p.

Lietman, P.L., 1997, Evaluation of agricultural best-management practices in the Conestoga River headwaters, Pennsylvania-A summary report, 1982-90: U.S. Geological Survey Water-Supply Paper 2493, 69 p.
Lindsey, B.D., and Bickford, T.M., 1999, Hydrogeologic framework and sampling design for an assessment of agricultural pesticides in ground water in Pennsylvania: U.S. Geological Survey Water-Resources Investigations Report 99-4076, 44 p.

Lindsey, B.D., Breen, K.J., Bilger, M.D., and Brightbill, R.A., 1998, Water quality in the lower Susquehanna River Basin, Pennsylvania and Maryland, 1992-95: U.S. Geological Survey Circular 1168, 38 p.

Lindsey, B.D., and Koch, M.L., 2004, Determining sources of water and contaminants to wells in a carbonate aquifer near Martinsburg, Blair County, Pennsylvania, by use of geochemical indicators, analysis of anthropogenic contaminants, and simulation of ground water flow: U.S. Geological Survey Scientific Investigations Report 2004-5124, 46 p., available at http://pubs.usgs.gov/sir/2004/5124/.

Lindsey, B.D., Loper, C.A., and Hainly, R.A., 1997, Nitrate in ground water and stream base flow in the Lower Susquehanna River Basin, Pennsylvania and Maryland: U.S. Geological Survey Water-Resources Investigations Report 97-4146, 66 p.

Low, D.J., Chichester, D.C., and Zarr, L.F., 2008, Selected ground-water-quality data in Pennsylvania-1979-2006: U.S. Geological Survey Data Series 314, 22 p., available at http://pubs.usgs.gov/ds/314/.

Low, D.J., and Conger, R.W., 2002, Ground-water availability in part of the Borough of Carroll Valley, Adams County, Pennsylvania, and the establishment of a drought monitor well: U.S. Geological Survey Water-Resources Investigations Report 02-4273, 78 p.

Madsen, J.E., Sandstrom, M.W., and Zaugg, S.D., 2003, Methods of analysis by the U.S. Geological Survey National Water Quality Laboratory-A method supplement for the determination of fipronil and degradates in water by gas chromatography/mass spectrometry: U.S. Geological Survey Open-File Report 02-462, 11 p.

Multi-Resolution Land Characteristics, 1992, National land cover database 1992: accessed January 2008 at http://www.mrlc.gov/landcover.usgs.gov/natlandcover.php

Multi-Resolution Land Characteristics, 2001, National land cover database 2001: accessed January 2008 at http://www.mrlc.gov/mrlc2k_nlcd.asp

Munch, J.W., ed., 1995, Measurement of N-methyl carbamoyloximes and n-methyl-carabamates in water by direct aqueous injection HPLC with post column derivatization: U.S. Environmental Protection Agency Method $531.1,23 \mathrm{p}$.

Ott, R.L., 1993, An introduction to statistical methods and data analysis: Belmont, Calif., Duxbury Press, 1,051 p. 
Pennsylvania Department of Agriculture, 1997, Pennsylvania Agricultural Statistics 1996-1997: Harrisburg, Pa., p. 71-73.

Pennsylvania Department of Agriculture, 1998, Pesticides and ground water strategy, January 2, 1998: Harrisburg, Pa., $36 \mathrm{p}$.

Pennsylvania Department of Agriculture, 2004, Pennsylvania Agricultural Statistics 2003-2004: Harrisburg, Pa., p. 13.

Pennsylvania Department of Agriculture, 2005, Pennsylvania Agricultural Statistics 2004-2005: Harrisburg, Pa., p. 3.

Pennsylvania Department of Agriculture, 2006, Pennsylvania Agricultural Statistics 2005-2006: Harrisburg, Pa., 3 p.

Pennsylvania Department of Agriculture, 2007, Pennsylvania Agricultural Statistics 2006-2007: Harrisburg, Pa., 3 p.

Pennsylvania Department of Environmental Protection, 2008, Triennial review of water quality standards: Pennsylvania Bulletin, v. 38, no. 2 (January 12, 2008), p. 241.

SAS Institute, 1990, SAS user's guide-The CORR procedure-Version 6 ( $3^{\text {rd }}$ ed.): Cary, N.C., SAS Institute Pub., p. 209-235.

Scott, J.C., 1990, Computerized stratified random site-selection approaches for design of a ground-water-quality sampling network: U.S. Geological Survey Water-Resources Investigations Report 90-4101, 109 p.

Uitenbroek, D.G., 1997, Fisher exact SISA: accessed April 17, 2009, at http://www.quantitativeskills.com/sisa/ statistics/fisher.htm

U.S. Department of Agriculture National Agricultural Statistics Service, 1997a, Agricultural chemical usage 1996 vegetable summary: accessed December 28, 2008, at http://usda.mannlib.cornell.edu/usda/nass/ AgriChemUsVeg/1990s/1997/ AgriChemUsVeg-07-15-1997.txt

U.S. Department of Agriculture National Agricultural Statistics Service, 1997b, Pennsylvania Statistics: accessed December 28, 2008, at http://www.nass.usda.gov/ Statistics_by_State/Pennsylvania/index.asp

U.S. Department of Agriculture National Agricultural Statistics Service, 2004, Agricultural chemical usage 2003 field crops summary: Washington, D.C., p. 70.

U.S. Department of Agriculture National Agricultural Statistics Service, 2005a, Agricultural chemical usage 2004 vegetables summary: Washington, D.C., p. 77, 155.

U.S. Department of Agriculture National Agricultural Statistics Service, 2005b, Pennsylvania Statistics: accessed December 28, 2008, at http://www.nass.usda.gov/ Statistics_by_State/Pennsylvania/index.asp
U.S. Department of Agriculture National Agricultural Statistics Service, 2006a, Agricultural chemical usage 2005 field crops summary: Washington, D.C., p. 33, 68.

U.S. Department of Agriculture National Agricultural Statistics Service, 2006b, Agricultural chemical usage 2005 fruit summary: Washington, D.C., p. 32-34, 102, 156-157.

U.S. Department of Agriculture National Agricultural Statistics Service, 2006c, Pennsylvania Statistics: accessed December 28, 2008, at http://www.nass.usda.gov/ Statistics_by_State/Pennsylvania/index.asp

U.S. Department of Agriculture National Agricultural Statistics Service, 2007a, Agricultural chemical usage 2006 field crops summary: Washington, D.C., p. 38, 70.

U.S. Department of Agriculture National Agricultural Statistics Service, 2007b, Agricultural chemical usage 2006 vegetables summary: Washington, D.C., p. 37,100.

U.S. Environmental Protection Agency, 2000a, Policy and program requirements for the mandatory agency-wide quality system: USEPA Order 5360.1 A2, May 5, 2000, 13 p.

U.S. Environmental Protection Agency, 2000b, Cyanazine cancellation order: Federal Register Environmental Documents, v. 65, no. 4, January 6, 2000.

U.S. Environmental Protection Agency, 2004, 2004 Edition of the Drinking Water Standards and Health Advisories: accessed March 4, 2009, at http://www.epa.gov/waterscience/criteria/drinking/ \#dw-standards/dwstandards2004[1].pdf

U.S. Environmental Protection Agency, 2006, Ground water \& drinking water, Drinking water contaminants: accessed October 8, 2008, at http://www.epa.gov/safewater/hfacts.html

U.S. Environmental Protection Agency, 2008, Water Quality Criteria, Drinking Water Health Advisories: accessed October 8, 2008, at http://epa.gov/waterscience/criteria/drinking/.

U.S. Geological Survey, 2005, State boundary and stream GIS data: accessed February 14, 2008, at http://www.nationalatlas.gov/atlasftp.html/.

U.S. Geological Survey, 2008, USGS ground-water data for Pennsylvania from National Water Information System-Web Interface: accessed December 15, 2008, at http://waterdata.usgs.gov/pa/nwis/gw

van Belle, G., and Hughes, J.P., 1984, Nonparametric tests for trend in water quality: Water Resources Research, v. 20, p. 127-136. 
Wilde, F.D., ed., variously dated, Field measurements (ver. 1.2: $\mathrm{pH}, 7 / 2003$; specific conductance, $8 / 2005$; temperature, 4/2004; ver. 2.1: dissolved oxygen 6/2006; turbidity 9/2005): U.S. Geological Survey Techniques of WaterResources Investigations, book 9, chap. A6, accessed June 17, 2008, at http://pubs.water.usgs.gov/twri9A6/.

Wilde, F.D., ed., April 2004, Cleaning of equipment for water sampling (ver. 2.0): U.S. Geological Survey Techniques of Water-Resources Investigations, book 9, chap. A3, accessed August 9, 2007, at http://pubs.water.usgs.gov/twri9A3

Wilde, F.D., Radtke, D.B., Gibs, Jacob, and Iwatsubo, R.T., eds., September 1999, National field manual for the collection of water-quality data - Collection of water samples: U.S. Geological Survey Techniques of WaterResources Investigations, book 9, chap. A4, variously paged.

Wilde, F.D., Radtke, D.B., Gibs, Jacob, and Iwatsubo, R.T., eds., April 2004, Processing of water samples (version 2.1): U.S. Geological Survey Techniques of WaterResources Investigations, book 9, chap. A5, accessed March 15, 2007, at http://pubs.water.usgs.gov/twri9A5

Williams, J.H., Taylor, L.E., and Low, D.J., 1998, Hydrogeology and groundwater quality of the glaciated valleys of Bradford, Tioga, and Potter Counties, Pennsylvania: Pennsylvania Geological Survey, $4^{\text {th }}$ ser., Water Resource Report $68,89 \mathrm{p}$.

Zaugg, S.D., Sandstrom, M.W., Smith, S.G., and Fehlberg, K.M., 1995, Methods of analysis by the U.S. Geological Survey National Water Quality Laboratory-Determination of pesticides in water by $\mathrm{C}-18$ solid-phase extraction and capillary-column gas chromatography/mass spectrometry with selected-ion monitoring: U.S. Geological Survey Open-File Report 95-181, 60 p. 
Table 3. Records of wells sampled for assessments of pesticides in ground water from baseline-assessment areas and areas of special ground-water protection, 2003-07, Pennsylvania.

[-, not available; ft, feet; gal/min, gallons per minute]

Local well number: Well location:

Aquifer code:

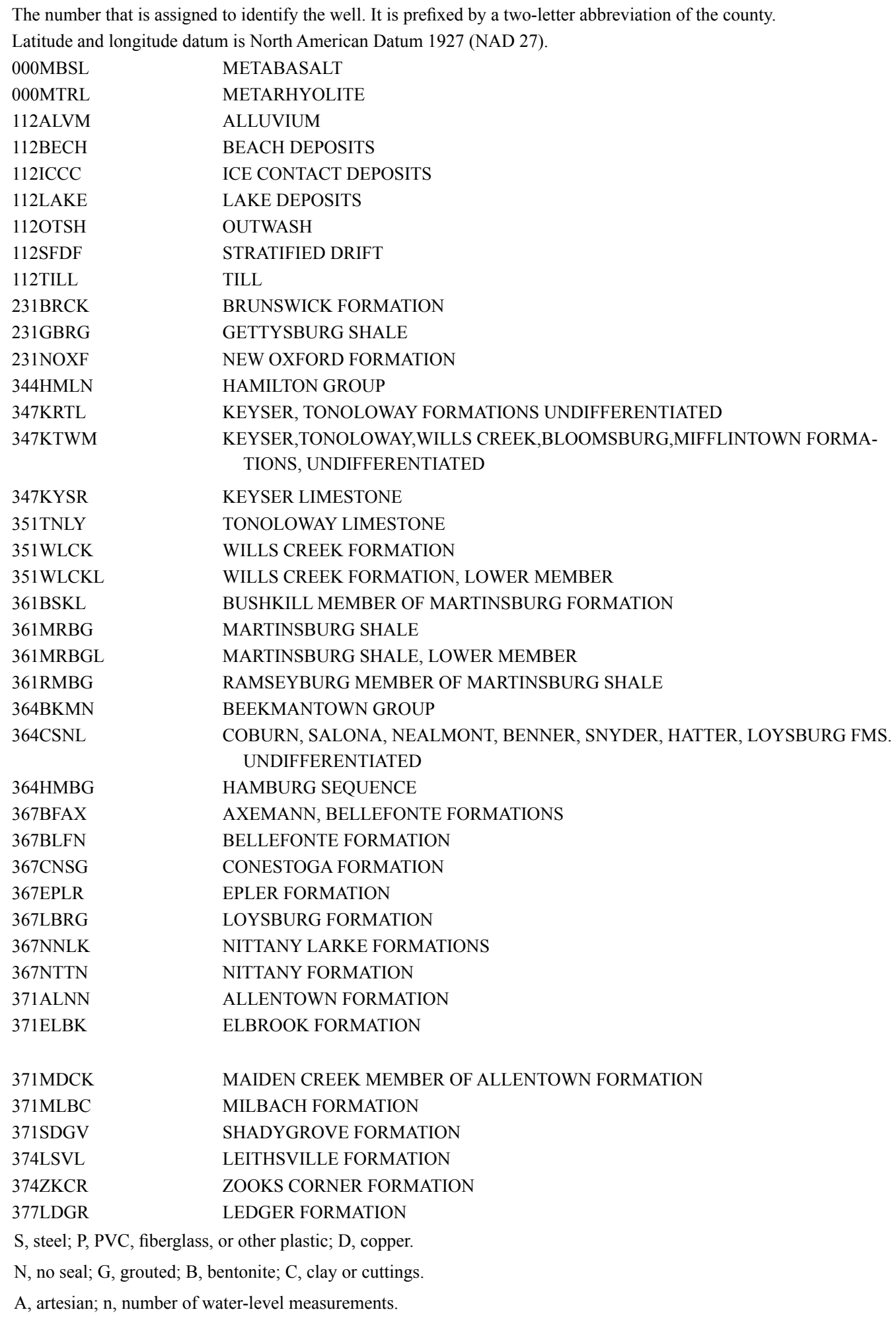


Table 3. Records of wells sampled for assessments of pesticides in ground water from baseline-assessment areas and areas of special ground-water protection, 2003-07, Pennsylvania.-Continued

\begin{tabular}{|c|c|c|c|c|c|c|c|c|}
\hline $\begin{array}{l}\text { Local well } \\
\text { number }\end{array}$ & Latitude & Longitude & Aquifer code & $\begin{array}{l}\text { Depth to top of } \\
\text { water-bearing } \\
\text { unit } \\
\text { (ft) }\end{array}$ & $\begin{array}{l}\text { Depth of well } \\
\text { (ft) }\end{array}$ & Casing length & $\begin{array}{l}\text { Casing } \\
\text { material }\end{array}$ & Type of seal \\
\hline eline-as & tareas & & & & & & & \\
\hline
\end{tabular}

Blue Ridge and Triassic Lowland hydrogeologic setting, 2003

\begin{tabular}{|c|c|c|c|c|c|c|c|}
\hline AD 1155 & 394849.8 & 772233.7 & 364BKMN & - & 202 & 34 & $\mathrm{~S}$ \\
\hline AD 1156 & 395212 & 772146.8 & $231 \mathrm{GBRG}$ & 55 & 220 & 60 & $\mathrm{~S}$ \\
\hline AD 1157 & 395713.3 & 771727.3 & 000MTRL & 30 & 260 & 42 & $\mathrm{~S}$ \\
\hline AD 1158 & 395706 & 771500 & 231GBRG & 55 & 220 & 60 & $\mathrm{~S}$ \\
\hline AD 1159 & 395807 & 771426 & $231 \mathrm{GBRG}$ & - & 160 & - & $\mathrm{S}$ \\
\hline AD 1160 & 395135 & 772213 & $231 \mathrm{GBRG}$ & 10 & 200 & 20 & $\mathrm{~S}$ \\
\hline AD 1161 & 395632 & 772232 & 000MTRL & 33 & 180 & 63 & $\mathrm{~S}$ \\
\hline AD 1162 & 395102 & 772257 & 000MTRL & 50 & 180 & 60 & $\mathrm{~S}$ \\
\hline AD 1163 & 395930 & 771536 & 000MTRL & 49 & 190 & 53 & $\mathrm{~S}$ \\
\hline AD 1173 & 395417.1 & 772025.6 & 231GBRG & - & 99 & 99 & $\mathrm{~S}$ \\
\hline AD 1174 & 395554.7 & 771647.8 & $231 \mathrm{GBRG}$ & - & 225 & - & $\mathrm{S}$ \\
\hline AD 1175 & 395648.8 & 771747.7 & $231 \mathrm{GBRG}$ & - & 155 & 26 & $\mathrm{~S}$ \\
\hline AD 1176 & 395919.4 & 771836 & 000MBSL & - & 175 & 55 & $\mathrm{~S}$ \\
\hline AD 1177 & 395923 & 771400.4 & 000MTRL & 30 & 120 & 44 & $\mathrm{~S}$ \\
\hline AD 1178 & 395605.1 & 771914.7 & 000MTRL & 30 & 140 & - & $\mathrm{S}$ \\
\hline AD 1179 & 400119 & 771034 & 000MBSL & 25 & 200 & 63 & $\mathrm{~S}$ \\
\hline AD 1180 & 400045.2 & 771642 & 000MTRL & 28 & 180 & - & $\mathrm{S}$ \\
\hline AD 1181 & 400101 & 771248.4 & 000MTRL & 56 & 140 & 60 & $\mathrm{~S}$ \\
\hline AD 1182 & 400032.6 & 771304 & 000MTRL & 32 & 210 & 40 & $\mathrm{~S}$ \\
\hline CU 951 & 400324 & 771009 & 000MTRL & 16 & 90 & 21 & $\mathrm{~S}$ \\
\hline
\end{tabular}

\begin{tabular}{|c|c|c|c|c|c|c|c|}
\hline ER 176 & 415409 & 802112 & 112TILL & - & 30 & 30 & $\mathrm{~S}$ \\
\hline ER 243 & 415924 & 801953 & 112OTSH & - & 88 & 88 & $\mathrm{~S}$ \\
\hline ER 295 & 415437 & 802423 & 112OTSH & - & 80 & 78 & $\mathrm{~S}$ \\
\hline ER 318 & 415718 & 802415 & 112TILL & - & 86 & 86 & $\mathrm{~S}$ \\
\hline ER 369 & 420055 & 801605 & 112OTSH & - & 49 & 49 & $\mathrm{~S}$ \\
\hline ER 428 & 420156 & 801305 & 112OTSH & - & 41 & 41 & $\mathrm{~S}$ \\
\hline ER 675 & 421403 & 795029 & 112OTSH & - & 94 & 94 & $\mathrm{~S}$ \\
\hline ER 713 & 421225 & 795317 & 112TILL & - & 32 & 32 & - \\
\hline ER 952 & 420511 & 800304 & 112OTSH & - & 40 & 40 & $\mathrm{~S}$ \\
\hline ER 1235 & 415438 & 803058 & 112OTSH & - & 52 & 52 & - \\
\hline ER 1242 & 415746 & 802527 & 112BECH & - & 34 & 34 & - \\
\hline ER 1405 & 420042 & 801749 & 112BECH & - & 45 & 45 & - \\
\hline ER 3504 & 415941.3 & 802421.4 & 112BECH & - & 18 & - & $\mathrm{S}$ \\
\hline ER 3505 & 415845.2 & 802033.3 & 112OTSH & - & 89 & 97 & $\mathrm{~S}$ \\
\hline ER 3506 & 415931.9 & 801701.9 & 112LAKE & - & 111.8 & 111.8 & $\mathrm{~S}$ \\
\hline ER 3507 & 420210.6 & 801125.4 & 112ALVM & - & 33 & 33 & $\mathrm{~S}$ \\
\hline ER 3508 & 421503.4 & 794622 & 112OTSH & - & 20 & 20 & $\mathrm{~S}$ \\
\hline ER 3509 & 421158.1 & 795600.7 & 112OTSH & - & 80 & 80 & $\mathrm{~S}$ \\
\hline ER 3510 & 421102.2 & 795033.1 & 112OTSH & - & 15 & 15 & - \\
\hline ER 3511 & 420853.5 & 795640 & 112ALVM & - & 39 & 19.8 & $\mathrm{~S}$ \\
\hline
\end{tabular}


Table 3. Records of wells sampled for assessments of pesticides in ground water from baseline-assessment areas and areas of special ground-water protection, 2003-07, Pennsylvania.-Continued

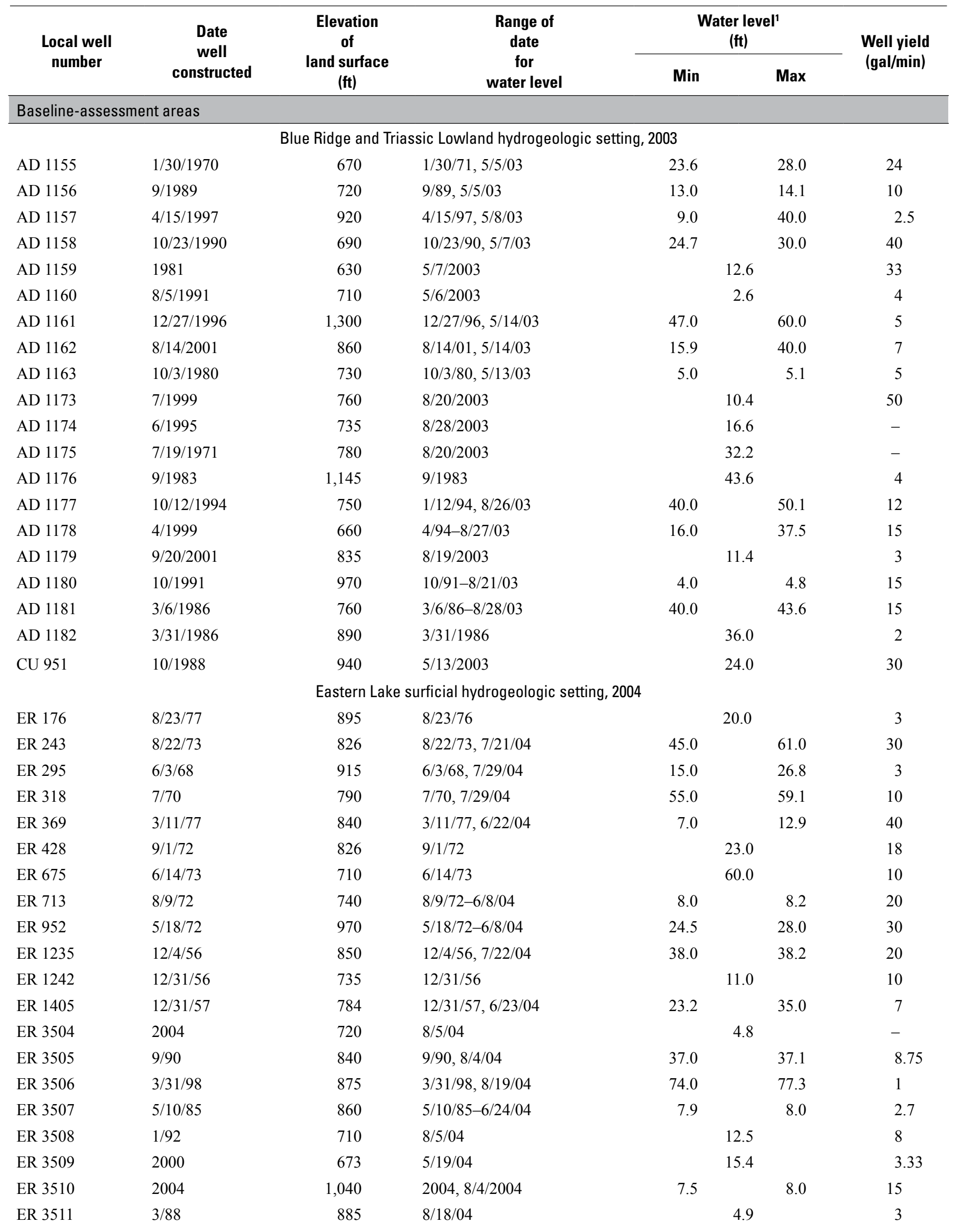


Table 3. Records of wells sampled for assessments of pesticides in ground water from baseline-assessment areas and areas of special ground-water protection, 2003-07, Pennsylvania.-Continued

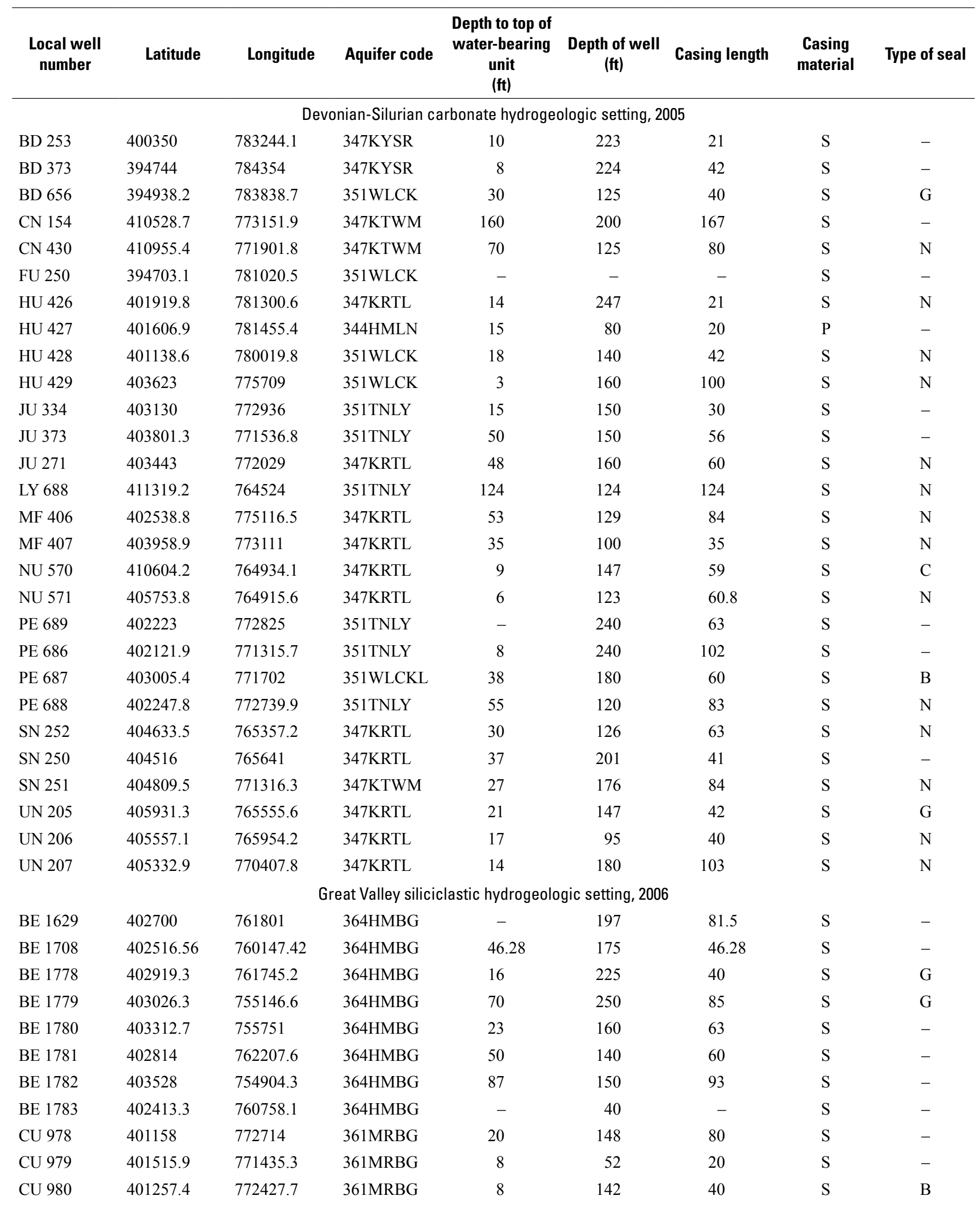


Table 3. Records of wells sampled for assessments of pesticides in ground water from baseline-assessment areas and areas of special ground-water protection, 2003-07, Pennsylvania.-Continued

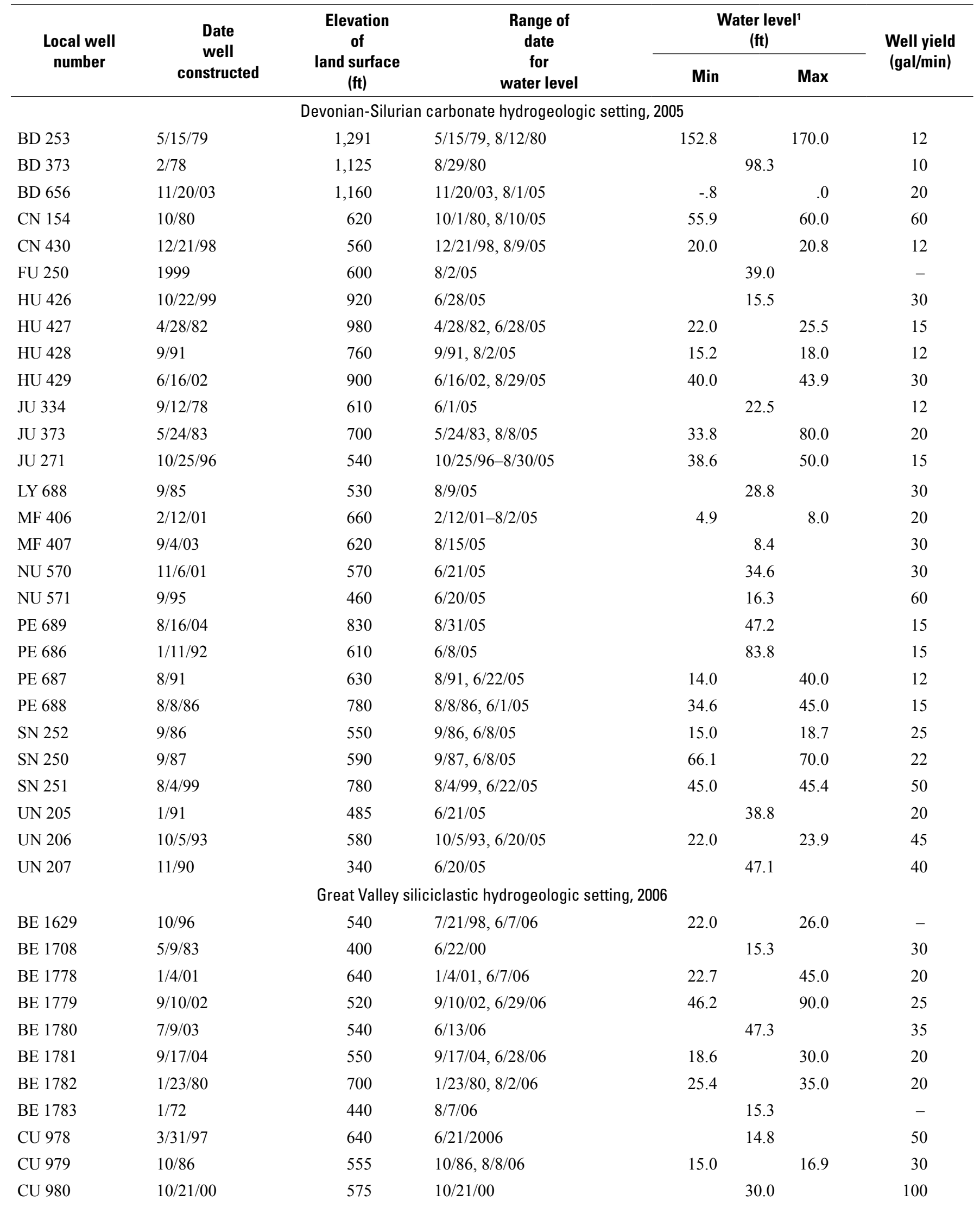


Table 3. Records of wells sampled for assessments of pesticides in ground water from baseline-assessment areas and areas of special ground-water protection, 2003-07, Pennsylvania.-Continued

\begin{tabular}{|c|c|c|c|c|c|c|c|c|}
\hline $\begin{array}{l}\text { Local well } \\
\text { number }\end{array}$ & Latitude & Longitude & Aquifer code & $\begin{array}{c}\text { Depth to top of } \\
\text { water-bearing } \\
\text { unit } \\
\text { (ft) }\end{array}$ & $\begin{array}{c}\text { Depth of well } \\
\text { (ft) }\end{array}$ & Casing length & $\begin{array}{l}\text { Casing } \\
\text { material }\end{array}$ & Type of seal \\
\hline \multicolumn{9}{|c|}{ Great Valley siliciclastic hydrogeologic setting, 2006-Continued } \\
\hline CU 981 & 401505.6 & 771956.5 & $361 \mathrm{MRBG}$ & - & 190 & 65 & $\mathrm{~S}$ & - \\
\hline CU 982 & 401652.5 & 770634.4 & 361MRBG & - & 223 & 40 & $\mathrm{~S}$ & - \\
\hline DA 870 & 401936.6 & 763808.6 & 364HMBG & 40 & 200 & 60 & $\mathrm{~S}$ & - \\
\hline FR 830 & 394727.3 & 775320.9 & $361 \mathrm{MRBG}$ & 30 & 225 & 42 & $\mathrm{~S}$ & $\mathrm{~N}$ \\
\hline FR 831 & 395746 & 774337 & 361MRBG & 39 & 220 & 63 & $\mathrm{~S}$ & G \\
\hline FR 833 & 395117.4 & 774640.3 & 361MRBG & 22 & 198 & 42 & $\mathrm{~S}$ & $\mathrm{~N}$ \\
\hline LB 1250 & 402425.9 & 762452.2 & 364HMBG & 16 & 150 & 81 & $\mathrm{~S}$ & G \\
\hline LE 1426 & 403651.8 & 754339 & 364HMBG & 55 & 250 & 75 & $\mathrm{~S}$ & $\mathrm{G}$ \\
\hline LE 1427 & 404523.5 & 754106.1 & 361MRBG & 67 & 224 & 76 & $\mathrm{~S}$ & G \\
\hline LE 1428 & 404113.7 & 754535.9 & $361 \mathrm{MRBG}$ & 12 & 100 & 26 & $\mathrm{~S}$ & G \\
\hline LE 1429 & 403534.5 & 754037.5 & 361MRBG & 35 & 200 & 40 & $\mathrm{~S}$ & G \\
\hline NP 818 & 404934.68 & 751001.77 & 361MRBG & 33.18 & 260 & 33.08 & $\mathrm{~S}$ & - \\
\hline NP 826 & 404852 & 751450 & 361BSKL & 18 & 190 & 30 & $\mathrm{~S}$ & $\mathrm{~N}$ \\
\hline NP 827 & 405328.1 & 750602 & 361RMBG & 69 & 94 & 71 & $\mathrm{~S}$ & - \\
\hline NP 828 & 404522.7 & 752645.3 & 361MRBG & 48 & 165 & 58 & $\mathrm{D}$ & G \\
\hline BR 885 & - & - & 112ALVM & - & - & - & $\mathrm{S}$ & - \\
\hline BR 886 & 414625 & 762359 & 112ALVM & - & 71 & 71 & $\mathrm{~S}$ & - \\
\hline BR 887 & 414612 & 764418 & 112SFDF & - & 108 & 108 & $\mathrm{~S}$ & - \\
\hline BR 888 & 414326 & 761411 & 112ALVM & - & 36 & 36 & $\mathrm{~S}$ & - \\
\hline $\mathrm{CN} 62$ & - & - & 112SFDF & - & 47 & 41 & - & - \\
\hline CO 143 & - & - & $112 \mathrm{OTSH}$ & - & 62 & 57 & $\mathrm{P}$ & - \\
\hline CO 590 & 411216.7 & 762251 & 112ALVM & - & 46 & 46 & $\mathrm{~S}$ & - \\
\hline LU 778 & 410532 & 760752 & 112ALVM & - & - & - & $\mathrm{S}$ & - \\
\hline LY 679 & 412647 & 765856 & 112ALVM & - & 40 & 40 & $\mathrm{~S}$ & - \\
\hline LY 690 & 411155 & 764325 & 112ALVM & - & 40 & 40 & $\mathrm{~S}$ & - \\
\hline LY 691 & 411431 & 764804 & 112ALVM & - & - & - & $\mathrm{S}$ & - \\
\hline LY 692 & 411213 & 771034 & 112ALVM & - & 60 & 60 & $\mathrm{~S}$ & - \\
\hline MO 695 & 405508 & 752239 & 112ALVM & - & 143 & 143 & $\mathrm{~S}$ & - \\
\hline NU 110 & 410854 & 765309 & 112ALVM & - & 41 & - & - & - \\
\hline NU 578 & - & - & 112ALVM & - & 50 & - & $\mathrm{S}$ & - \\
\hline PI 236 & - & - & 112ICCC & - & 165 & 165 & - & - \\
\hline
\end{tabular}


Table 3. Records of wells sampled for assessments of pesticides in ground water from baseline-assessment areas and areas of special ground-water protection, 2003-07, Pennsylvania.-Continued

\begin{tabular}{|c|c|c|c|c|c|c|}
\hline \multirow{2}{*}{$\begin{array}{l}\text { Local well } \\
\text { number }\end{array}$} & \multirow{2}{*}{$\begin{array}{c}\text { Date } \\
\text { well } \\
\text { constructed }\end{array}$} & \multirow{2}{*}{$\begin{array}{c}\begin{array}{c}\text { Elevation } \\
\text { of } \\
\text { land surface } \\
\text { (ft) }\end{array} \\
\end{array}$} & \multirow{2}{*}{$\begin{array}{c}\text { Range of } \\
\text { date } \\
\text { for } \\
\text { water level }\end{array}$} & \multicolumn{2}{|c|}{$\begin{array}{c}\text { Water level' } \\
\text { (ft) }\end{array}$} & \multirow{2}{*}{$\begin{array}{r}\text { Well yield } \\
\text { (gal/min) }\end{array}$} \\
\hline & & & & Min & Max & \\
\hline \multicolumn{7}{|c|}{ Great Valley siliciclastic hydrogeologic setting, 2006-Continued } \\
\hline CU 981 & $6 / 11 / 86$ & 580 & $7 / 27 / 06$ & & & - \\
\hline CU 982 & $8 / 23 / 89$ & 470 & $7 / 31 / 06$ & & & - \\
\hline DA 869 & $4 / 2 / 96$ & 490 & $6 / 6 / 06$ & & & 20 \\
\hline DA 870 & $5 / 14 / 98$ & 430 & $6 / 6 / 06$ & & & 40 \\
\hline FR 830 & $6 / 19 / 95$ & 600 & $6 / 19 / 95,6 / 20 / 06$ & 25.0 & 150.0 & 10 \\
\hline FR 831 & $3 / 13 / 03$ & 600 & $3 / 10 / 03,6 / 14 / 06$ & 18.0 & 20.7 & 17 \\
\hline FR 833 & $2 / 14 / 94$ & 570 & $2 / 14 / 94,6 / 20 / 06$ & 20.0 & 35.9 & 25 \\
\hline FR 832 & $10 / 26 / 98$ & 660 & $10 / 26 / 98,6 / 14 / 06$ & 30.0 & 47.3 & 50 \\
\hline FR 834 & 1967 & 680 & $6 / 21 / 06$ & \multicolumn{2}{|c|}{27.4} & - \\
\hline LB 1247 & $4 / 8 / 99$ & 600 & $6 / 8 / 06$ & \multicolumn{2}{|c|}{26.8} & 45 \\
\hline LB 1250 & $12 / 19 / 97$ & 435 & $6 / 22 / 06$ & \multicolumn{2}{|c|}{18.2} & 30 \\
\hline LE 1426 & $2 / 21 / 96$ & 805 & $2 / 21 / 1996$ & \multicolumn{2}{|c|}{60.0} & 18 \\
\hline LE 1427 & $11 / 3 / 00$ & 700 & $11 / 3 / 00,7 / 18 / 06$ & 21.6 & 39.0 & 12 \\
\hline LE 1428 & $8 / 30 / 00$ & 580 & $8 / 30 / 00,7 / 24 / 06$ & \multicolumn{2}{|c|}{25.0} & 16 \\
\hline LE 1429 & $6 / 26 / 98$ & 710 & $6 / 26 / 98,8 / 7 / 06$ & 18.2 & 40.0 & 8 \\
\hline NP 818 & $7 / 91$ & 740 & $6 / 14 / 00,8 / 1 / 06$ & 47.0 & 56.3 & 5 \\
\hline NP 826 & $6 / 95$ & 700 & $6 / 95,7 / 19 / 06$ & 40.0 & 40.4 & 6 \\
\hline NP 827 & $3 / 7 / 73$ & 620 & $3 / 7 / 73$ & \multicolumn{2}{|c|}{30.0} & 25 \\
\hline NP 828 & $7 / 03$ & 720 & $7 / 03,7 / 6 / 06$ & 31.9 & 55.0 & 11 \\
\hline \multicolumn{7}{|c|}{ Northeastern Glaciated surficial hydrogeologic setting, 2007} \\
\hline BR 226 & $4 / 72$ & 765 & $4 / 1 / 72,4 / 17 / 72$ & 17 & 17 & 1683 \\
\hline BR 875 & $7 / 04$ & 680 & $7 / 04,8 / 16 / 07$ & 8 & 14.2 & 10 \\
\hline BR 878 & $7 / 02$ & 780 & $7 / 02-8 / 15 / 07$ & 19 & 25 & 15 \\
\hline BR 882 & 1988 & 910 & $8 / 15 / 07$ & \multicolumn{2}{|c|}{19.4} & - \\
\hline BR 884 & 1977 & 1,090 & - & - & - & - \\
\hline BR 885 & 1980 & 730 & - & - & - & - \\
\hline BR 886 & $5 / 21 / 04$ & 710 & $5 / 21 / 04,7 / 25 / 07$ & 26.7 & 32 & 30 \\
\hline BR 887 & $9 / 15 / 64$ & 970 & $9 / 15 / 64$ & \multicolumn{2}{|c|}{2.0} & 32 \\
\hline BR 888 & 1973 & 740 & - & - & - & - \\
\hline $\mathrm{CN} 62$ & 1940 & 550 & $11 / 1 / 42$ & \multicolumn{2}{|c|}{15.0} & 350 \\
\hline CO 143 & $8 / 16 / 79$ & 490 & $6 / 10 / 80-4 / 30 / 81$ & 21.57 & 26.4 & - \\
\hline CO 590 & $8 / 5 / 75$ & 785 & $8 / 5 / 75,8 / 14 / 07$ & 20 & 20 & 10 \\
\hline LU 778 & 1955 & 510 & $5 / 29 / 07$ & \multicolumn{2}{|c|}{28.6} & - \\
\hline LY 679 & 1998 & 750 & $8 / 9 / 07-8 / 22 / 07$ & 14.8 & 16.28 & - \\
\hline LY 690 & 1970 & 650 & $5 / 30 / 07$ & \multicolumn{2}{|c|}{23.8} & - \\
\hline LY 691 & 1998 & 540 & $5 / 24 / 07$ & \multicolumn{2}{|c|}{11.6} & - \\
\hline LY 692 & 1970 & 545 & - & - & - & - \\
\hline MO 695 & $8 / 02$ & 750 & $8 / 27 / 07$ & \multicolumn{2}{|c|}{35.4} & 45 \\
\hline NU 110 & - & 485 & $11 / 7 / 75-8 / 23 / 07$ & 16.75 & 19 & 30 \\
\hline NU 578 & 1980 & 440 & $8 / 23 / 07$ & \multicolumn{2}{|c|}{20.5} & - \\
\hline PI 236 & $5 / 15 / 69$ & 410 & $5 / 15 / 69$ & \multicolumn{2}{|c|}{40.0} & 20 \\
\hline
\end{tabular}


Table 3. Records of wells sampled for assessments of pesticides in ground water from baseline-assessment areas and areas of special ground-water protection, 2003-07, Pennsylvania.-Continued

\begin{tabular}{|c|c|c|c|c|c|c|c|c|}
\hline $\begin{array}{l}\text { Local well } \\
\text { number }\end{array}$ & Latitude & Longitude & Aquifer code & $\begin{array}{l}\text { Depth to top of } \\
\text { water-bearing } \\
\text { unit } \\
\text { (ft) }\end{array}$ & $\begin{array}{l}\text { Depth of well } \\
\text { (ft) }\end{array}$ & Casing length & $\begin{array}{c}\text { Casing } \\
\text { material }\end{array}$ & Type of seal \\
\hline \multicolumn{9}{|c|}{ Northeastern Glaciated surficial hydrogeologic setting, 2007-Continued } \\
\hline SQ 453 & 415915.3 & 753550.7 & 112SFDF & - & 68 & 68 & $\mathrm{~S}$ & $\mathrm{~N}$ \\
\hline TI 725 & 414934.1 & 771716.5 & 112SFDF & - & 45 & 45 & $\mathrm{~S}$ & $\mathrm{~N}$ \\
\hline TI 728 & - & - & 112ALVM & - & 20 & 17 & $\mathrm{~S}$ & B \\
\hline WY 193 & 413152 & 755634 & 112ALVM & - & 48 & 48 & $\mathrm{~S}$ & - \\
\hline WY 194 & 412632 & 755120 & 112ALVM & - & 55 & 55 & S & - \\
\hline WY 195 & 413558 & 760556 & 112ALVM & - & 74 & 74 & $\mathrm{~S}$ & $\mathrm{~N}$ \\
\hline WY 196 & 413733 & 754549 & 112ALVM & - & 30 & 20 & $\mathrm{~S}$ & - \\
\hline \multicolumn{9}{|c|}{ Great Valley carbonate hydrogeologic setting, 2003 and (or) 2004} \\
\hline BE 1619 & 402934 & 754818 & 371MDCK & 25 & 150 & 120 & S & $\mathrm{N}$ \\
\hline CU 908 & 400513.3 & 772747.1 & 371SDGV & 42 & 182 & 120 & $\mathrm{~S}$ & - \\
\hline CU 917 & 400834.2 & 771344.4 & 371ELBK & 40 & 200 & 60 & $\mathrm{~S}$ & $\mathrm{~N}$ \\
\hline LB 1160 & 401856.3 & 763450 & 367EPLR & 40 & 180 & 95 & $\mathrm{~S}$ & - \\
\hline NP 805 & 404144 & 752415 & 367EPLR & 115 & 140 & 114 & $\mathrm{~S}$ & G \\
\hline \multicolumn{9}{|c|}{ Appalachian Mountain carbonate hydrogeologic setting, 2003 and 2004} \\
\hline BD 653 & 401524.9 & 782135.2 & 367 NNLK & 30 & 170 & 84 & S & $\mathrm{N}$ \\
\hline CE 672 & 405251.6 & 773015.4 & $364 \mathrm{CSNL}$ & - & 200 & 125 & $\mathrm{~S}$ & - \\
\hline LY 686 & 410805 & 771314 & 367LBRG & 120 & 175 & 134.5 & $\mathrm{~S}$ & $\mathrm{~N}$ \\
\hline MF 401 & 403712.2 & 774320.1 & 367BLFN & - & 120 & 40 & $\mathrm{~S}$ & - \\
\hline \multicolumn{9}{|c|}{ Piedmont carbonate hydrogeologic setting, 2003 and (or) 2004} \\
\hline LN 1763 & 395542 & 761853 & 367CNSG & - & 250 & 46 & $\mathrm{~S}$ & - \\
\hline LN 2005 & 400629.5 & 763652.5 & $371 \mathrm{MLBC}$ & 11 & 100 & 40 & $\mathrm{~S}$ & - \\
\hline LN 2008 & 400557.7 & 762812.7 & 371MLBC & 40 & 175 & 102 & S & - \\
\hline LN 2017 & 401255.1 & 761147.3 & 367EPLR & 20 & 160 & 42 & $\mathrm{~S}$ & - \\
\hline LN 2021 & 395952.3 & 761221.4 & $367 \mathrm{CNSG}$ & 27 & 150 & 41 & $\mathrm{~S}$ & $\mathrm{~N}$ \\
\hline \multicolumn{9}{|c|}{ Triassic Lowland hydrogeologic setting, 2003 and 2004} \\
\hline AD 1184 & 395955.1 & 770207.7 & $231 \mathrm{GBRG}$ & - & 180 & 101 & $\mathrm{~S}$ & G \\
\hline BK 3011 & 402704 & 752457 & 231BRCK & - & 100 & - & - & - \\
\hline LN 2113 & 401307 & 762243 & $231 \mathrm{NOXF}$ & 75 & 200 & 103 & $\mathrm{~S}$ & - \\
\hline MG 1449 & 401447.71 & 751935.18 & 231BRCK & - & 114.5 & 30 & $\mathrm{~S}$ & - \\
\hline \multicolumn{9}{|c|}{ Selected areas of special ground-water protection } \\
\hline \multicolumn{9}{|c|}{ Blair County, North Woodbury Township } \\
\hline BA 332 & - & - & $367 \mathrm{NTTN}$ & - & 100 & - & - & - \\
\hline BA $437^{2}$ & 401724 & 781958 & 367BFAX & 7 & 105 & 21 & $\mathrm{~S}$ & - \\
\hline BA 642 & 401724 & 781948 & 367NNLK & - & 325 & - & $\mathrm{P}$ & - \\
\hline BA 643 & 401723 & 781957 & 367BFAX & - & 330 & - & S & - \\
\hline BA 644 & 401733 & 781955 & 367BFAX & - & 145 & - & S & - \\
\hline BA 645 & 401738 & 781943 & 367BFAX & 15 & 207 & 60 & S & $\mathrm{N}$ \\
\hline
\end{tabular}


Table 3. Records of wells sampled for assessments of pesticides in ground water from baseline-assessment areas and areas of special ground-water protection, 2003-07, Pennsylvania.-Continued

\begin{tabular}{|c|c|c|c|c|c|c|}
\hline \multirow{2}{*}{$\begin{array}{l}\text { Local well } \\
\text { number }\end{array}$} & \multirow{2}{*}{$\begin{array}{c}\text { Date } \\
\text { well } \\
\text { constructed }\end{array}$} & \multirow{2}{*}{$\begin{array}{c}\text { Elevation } \\
\text { of } \\
\text { land surface } \\
\text { (ft) }\end{array}$} & \multirow{2}{*}{ 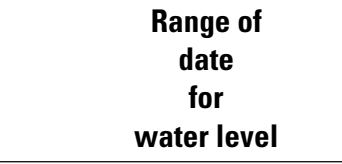 } & \multicolumn{2}{|c|}{$\begin{array}{l}\text { Water level' } \\
\text { (ft) }\end{array}$} & \multirow{2}{*}{$\begin{array}{l}\text { Well yield } \\
\text { (gal/min) }\end{array}$} \\
\hline & & & & Min & Max & \\
\hline \multicolumn{7}{|c|}{ Northeastern Glaciated surficial hydrogeologic setting, 2007—Continued } \\
\hline SQ 453 & $11 / 3 / 71$ & 1,030 & $11 / 3 / 71,7 / 5 / 07$ & 30 & 32 & 6 \\
\hline TI 725 & $8 / 90$ & 1,190 & $6 / 27 / 07$ & \multicolumn{2}{|c|}{10.6} & 18 \\
\hline TI 728 & $5 / 28 / 90$ & 1,040 & $5 / 28 / 90,6 / 28 / 07$ & 8.74 & 10.42 & 100 \\
\hline WY 193 & $3 / 28 / 95$ & 605 & $3 / 28 / 95,7 / 5 / 07$ & 25 & 31.8 & 20 \\
\hline WY 194 & $1 / 90$ & 580 & $1 / 90,6 / 20 / 07$ & 22 & 26.5 & 20 \\
\hline WY 195 & $6 / 2 / 00$ & 760 & $6 / 21 / 07$ & \multicolumn{2}{|c|}{52.8} & 20 \\
\hline WY 196 & $1 / 24 / 01$ & 730 & $1 / 24 / 01,9 / 4 / 07$ & 6 & 7.6 & 30 \\
\hline \multicolumn{7}{|c|}{ Great Valley carbonate hydrogeologic setting, 2003 and (or) 2004} \\
\hline BE 1619 & $6 / 26 / 89$ & 400 & $11 / 13 / 97-4 / 14 / 04(n=3)$ & 27.02 & 37.71 & - \\
\hline CU 908 & $3 / 22 / 91$ & 650 & $2 / 7 / 95-4 / 15 / 04(n=5)$ & 28.12 & 50.30 & 4.52 \\
\hline CU 917 & $3 / 9 / 89$ & 585 & $3 / 1 / 95-4 / 28 / 04(n=4)$ & 35.25 & 59.70 & 4.36 \\
\hline LB 1160 & $5 / 5 / 80$ & 440 & $5 / 5 / 80-7 / 19 / 95(n=4)$ & 86.00 & 104.49 & 4.3 \\
\hline NP 805 & $5 / 1 / 95$ & 400 & $1 / 14 / 98,4 / 1 / 03(n=2)$ & 66.30 & 78.52 & - \\
\hline \multicolumn{7}{|c|}{ Appalachian Mountain carbonate hydrogeologic setting, 2003 and 2004} \\
\hline BD 653 & $6 / 19 / 90$ & 1,370 & $5 / 26 / 94-4 / 26 / 04(n=5)$ & 47.42 & 64.10 & 4.80 \\
\hline CE 672 & 1988 & 1,190 & $4 / 19 / 94-4 / 29 / 04(n=5)$ & 84.24 & 131.50 & 6.82 \\
\hline LY 686 & $7 / 13 / 88$ & 765 & $7 / 13 / 88-4 / 27 / 04(n=3)$ & 82.20 & 110.00 & 60 \\
\hline MF 401 & 1991 & 870 & $6 / 21 / 94-4 / 13 / 04(n=4)$ & 3.47 & 16.90 & 9 \\
\hline \multicolumn{7}{|c|}{ Piedmont carbonate hydrogeologic setting, 2003 and (or) 2004} \\
\hline LN 1763 & $3 / 28 / 81$ & 435 & $5 / 24 / 91-3 / 31 / 04(n=3)$ & 36.00 & 40.85 & 8.5 \\
\hline LN 2005 & 1975 & 390 & $3 / 12 / 93-3 / 31 / 04(n=5)$ & 7.50 & 10.04 & 6.4 \\
\hline LN 2008 & $8 / 91$ & 370 & $5 / 14 / 93-4 / 9 / 03(n=3)$ & 48.70 & 70.40 & 4.3 \\
\hline LN 2017 & $7 / 92$ & 410 & $7 / 92-4 / 1 / 04(n=6)$ & 20.00 & 56.30 & 12 \\
\hline LN 2021 & $8 / 8 / 89$ & 370 & 3/29/93-3/30/04 (n= 5) & 22.10 & 28.20 & 8.41 \\
\hline \multicolumn{7}{|c|}{ Triassic Lowland hydrogeologic setting, 2003 and 2004} \\
\hline AD 1184 & $9 / 20 / 95$ & 500 & $9 / 20 / 95-4 / 8 / 04(n=3)$ & 11.18 & 40.00 & 10 \\
\hline BK 3011 & $10 / 21 / 92$ & 550 & $4 / 15 / 03,4 / 7 / 04(n=2)$ & A & $\mathrm{A}$ & - \\
\hline LN 2113 & $10 / 10 / 92$ & 500 & $4 / 2 / 03,4 / 6 / 04(n=2)$ & 32.60 & 36.50 & 100 \\
\hline MG 1449 & 1971 & 265 & 6/21/96-6/12/07 (n=7) & 10.49 & 11.24 & 55 \\
\hline \multicolumn{7}{|c|}{ Selected areas of special ground-water protection } \\
\hline \multicolumn{7}{|c|}{ Blair County, North Woodbury Township } \\
\hline BA 332 & 1945 & 1,440 & - & - & - & 20.00 \\
\hline BA $437^{2}$ & $6 / 10 / 80$ & 1,435 & $5 / 7 / 84-8 / 8 / 07(\mathrm{n}=22)$ & 14.8 & 37.1 & 6.6 \\
\hline BA 642 & 1994 & 1,455 & $8 / 25 / 05-9 / 6 / 05(n=2)$ & 41.7 & 44.4 & - \\
\hline BA 643 & 1960 & 1,445 & $8 / 25 / 05-9 / 1 / 05(n=2)$ & 39.1 & 39.1 & - \\
\hline BA 644 & 2005 & 1,440 & $9 / 1 / 05(\mathrm{n}=1)$ & \multicolumn{2}{|c|}{46.7} & - \\
\hline BA 645 & $10 / 25 / 04$ & 1,420 & $9 / 1 / 05(n=1)$ & \multicolumn{2}{|c|}{37.4} & 15 \\
\hline
\end{tabular}


Table 3. Records of wells sampled for assessments of pesticides in ground water from baseline-assessment areas and areas of special ground-water protection, 2003-07, Pennsylvania.-Continued

\begin{tabular}{|c|c|c|c|c|c|c|c|c|}
\hline $\begin{array}{l}\text { Local well } \\
\text { number }\end{array}$ & Latitude & Longitude & Aquifer code & $\begin{array}{l}\text { Depth to top of } \\
\text { water-bearing } \\
\text { unit } \\
\text { (ft) }\end{array}$ & $\begin{array}{c}\text { Depth of well } \\
\text { (ft) }\end{array}$ & Casing length & $\begin{array}{l}\text { Casing } \\
\text { material }\end{array}$ & Type of seal \\
\hline \multicolumn{9}{|c|}{ Berks County, Oley Township } \\
\hline BE 1298 & 402237 & 754455 & 371ALNN & 8 & 62 & 41 & $\mathrm{~S}$ & - \\
\hline BE $\mathbf{1 3 7 0}^{2,3}$ & 402238 & 754434 & 371ALNN & - & 110 & - & - & - \\
\hline BE 1774 & 402225 & 754448 & 371ALNN & 50 & 397 & 60 & $\mathrm{~S}$ & $\mathrm{~N}$ \\
\hline BE 1775 & 402227 & 754452 & 371ALNN & - & 320 & 64 & $\mathrm{~S}$ & - \\
\hline BE 1776 & 402225 & 754430 & 371ALNN & 15 & 180 & 42 & $\mathrm{~S}$ & - \\
\hline \multicolumn{9}{|c|}{ Lancaster County, Earl Township } \\
\hline LN 2000 & 400500 & 760637 & $374 Z K C R$ & - & 120 & - & $\mathrm{S}$ & - \\
\hline LN 2118 & 400448 & 760647 & 377LDGR & - & - & - & S & - \\
\hline LN 2119 & 400448 & 760627 & 377LDGR & 4 & 175 & 126 & $\mathrm{~S}$ & $\mathrm{G}$ \\
\hline
\end{tabular}

${ }^{1}$ Single water level indicates only a single measurement is on record.

${ }^{2}$ Detailed investigations of pesticide occurrence, concentration change related to water-level condition, and persistence done at these sites, $2003-07$.

${ }^{3}$ Additional reference water levels for BE 1370 where taken at BE 1774.
BE 1774
402225
754448
371ALNN
50
397
60
S
N 
Table 3. Records of wells sampled for assessments of pesticides in ground water from baseline-assessment areas and areas of special ground-water protection, 2003-07, Pennsylvania.-Continued

\begin{tabular}{|c|c|c|c|c|c|c|}
\hline \multirow{2}{*}{$\begin{array}{l}\text { Local well } \\
\text { number }\end{array}$} & \multirow{2}{*}{$\begin{array}{c}\text { Date } \\
\text { well } \\
\text { constructed }\end{array}$} & \multirow{2}{*}{$\begin{array}{c}\begin{array}{c}\text { Elevation } \\
\text { of }\end{array} \\
\text { land surface } \\
\text { (ft) }\end{array}$} & \multirow{2}{*}{$\begin{array}{c}\text { Range of } \\
\text { date } \\
\text { for } \\
\text { water level }\end{array}$} & \multicolumn{2}{|c|}{$\begin{array}{c}\text { Water level }{ }^{\mathbf{1}} \\
\text { (ft) }\end{array}$} & \multirow{2}{*}{$\begin{array}{c}\text { Well yield } \\
\text { (gal/min) }\end{array}$} \\
\hline & & & & Min & Max & \\
\hline \multicolumn{7}{|c|}{ Berks County, Oley Township } \\
\hline BE 1298 & $10 / 81$ & 330 & $12 / 31 / 81-8 / 23 / 05(n=32)$ & 13.9 & 23.3 & 60 \\
\hline BE $\mathbf{1 3 7 0}^{2,3}$ & - & 330 & $8 / 18 / 05,5 / 17 / 07(n=2)$ & 15.5 & 17.8 & - \\
\hline BE 1774 & $6 / 5 / 97$ & 356 & $6 / 5 / 97-5 / 17 / 05(n=15)$ & 31.0 & 41.8 & 8 \\
\hline BE 1775 & $6 / 05$ & 360 & $8 / 15 / 05-8 / 23 / 05(n=4)$ & 33.8 & 37.2 & - \\
\hline BE 1776 & $8 / 82$ & 345 & $8 / 0 / 82-8 / 23 / 05(n=2)$ & 20.0 & 27.2 & 35 \\
\hline \multicolumn{7}{|c|}{ Lancaster County, Earl Township } \\
\hline LN 2000 & 1992 & 440 & - & - & - & - \\
\hline LN 2118 & 1970 & 410 & $6 / 6 / 06(n=1)$ & \multicolumn{2}{|c|}{14.5} & - \\
\hline LN 2119 & $6 / 23 / 97$ & 440 & $6 / 5 / 06(n=1)$ & \multicolumn{2}{|c|}{45.6} & 50 \\
\hline
\end{tabular}

BE 1774

6/5/1997

356

$6 / 5 / 97-5 / 17 / 07(n=15)$

31.0

41.8

8 
Appendixes 1-4 


\section{Appendix 1. Methods for Estimating Pesticide Use}

Data for estimating pesticide use were obtained through U.S. Department of Agriculture Chemical Use Reports (U.S. Department of Agriculture National Agricultural Statistics Service, 1997a, 1997b, 2004, 2005a, 2005b, 2006a, 2006b, 2006c, 2007a, 2007b) and the Pennsylvania Agricultural Statistics published by Pennsylvania Department of Agriculture (1997). The Census of Agriculture provides accurate pesticide-use information, but these data were not used; direct comparison between past and present census surveys could not be made because the 2007 survey, which would best represent the 2003-07 study period, was not completed at the time this report was developed.

A U.S. Geological Survey method for estimating pesticide use (Thelin, 2000) was modified to use the best data available for the mid 1990s and the study period of 2003-07 for Pennsylvania and its counties. Statewide and county agricultural production and pesticide use are related as follows:

$$
P_{\text {County }}=A_{\text {County }} T_{P A} k_{P A} n,
$$

where

$$
\begin{aligned}
& P_{\text {County }} \quad \text { is pesticide total applied for county, in } \\
& \text { pounds, } \\
& A_{\text {County }} \text { is area of crop commodity harvested for }
\end{aligned}
$$

\section{Area Harvested}

Values for $A_{\text {County }}$ were from data published in Pennsylvania Agricultural Statistics Bulletins available for the study period (Pennsylvania Department of Agriculture, 2004, 2005, $2006,2007)$. The total area harvested for Pennsylvania, $A_{P A}$, is equivalent to the summation of $A_{\text {County }}$ for 66 counties ${ }^{1}$ :

$$
A_{P A}=\sum_{i=1}^{66} A_{\text {County }}
$$

Pesticide Applied

Data for pesticide use were not available for every crop for every year for every state in the United States. Values for pesticide use were based on the best available data that could be attained for the past and current study period. The data were obtained for representative years available during the study period for each crop commodity for Pennsylvania or representative pesticide-use data interpolated from adjacent states.

Values for $n, T_{P A}$, and $k_{P A}$ were taken directly from data published in the Agricultural Chemical Usage Summary Reports for Field Crops, Vegetables or Fruit (U.S. Department of Agriculture National Agricultural Statistics Service, 1997a, 1997b, 2004, 2005a, 2005b, 2006a, 2006b, 2006c, 2007a, 2007b) and are shown in table 1-1. The comparisons made for 21 of the 134 pesticides used statewide are based on area of crop commodity planted acres (not on acres harvested) for Pennsylvania (U.S. Department of Agriculture National Agricultural Statistics Service, 2004, 2005a, 2006a, 2006b, 2007a, 2007b). All other figures including countywide comparisons contain calculated data based on $\mathrm{A}_{\text {County }}$.

${ }^{1}$ No data for Philadelphia County. 
Table 1-1. Factors in computations of pesticide use.

[-, no data; Pennsylvania Department of Agriculture, 1997; U.S. Departmenof Agriculture, 1997a, 1997b, 2005a, 2005b, 2006a, 2006c]

\begin{tabular}{|c|c|c|c|c|c|c|}
\hline \multirow{2}{*}{ Pesticide } & \multicolumn{2}{|c|}{$\begin{array}{c}\text { Area applied factor, } \\
\text { percent }\end{array}$} & \multicolumn{2}{|c|}{$\begin{array}{l}\text { Application rate factor, } \\
\text { pounds per acre per year }\end{array}$} & \multicolumn{2}{|c|}{$\begin{array}{c}\text { Number of } \\
\text { applications factor }\end{array}$} \\
\hline & 1996 & 2004-05 & 1996 & 2004-05 & 1996 & 2004-05 \\
\hline Acetochlor & 17 & 11 & 2.07 & 1.610 & 1 & 1 \\
\hline Atrazine & 91 & 87 & 1.14 & 1.096 & 1 & 1 \\
\hline S-Metolachlor & - & 48 & - & 1.220 & - & 1 \\
\hline \multicolumn{7}{|c|}{ Sweet Corn } \\
\hline Acetochlor & - & - & - & - & - & - \\
\hline Atrazine & ${ }^{1} 45$ & 90 & ${ }^{1} 1.23$ & 1.41 & 1.1 & 1 \\
\hline Metolachlor & ${ }^{1} 40$ & - & ${ }^{1} 1.93$ & - & 1 & - \\
\hline
\end{tabular}

${ }^{1}$ Data interpolated for the same year from New Jersey chemical-use data.

\section{References Cited}

Pennsylvania Department of Agriculture, 1997, Pennsylvania Agricultural Statistics 1996-1997: Harrisburg, Pa., p. 71-73.

Pennsylvania Department of Agriculture, 2004, Pennsylvania Agricultural Statistics 2003-2004: Harrisburg, Pa., p. 13, 126.

Pennsylvania Department of Agriculture, 2005, Pennsylvania Agricultural Statistics 2004-2005: Harrisburg, Pa., p. $3,25,26$.

Pennsylvania Department of Agriculture, 2006, Pennsylvania 'Ag Snapshot' 2005: Pennsylvania Agricultural Statistics 20052006, Harrisburg, Pa., 3 p.

Pennsylvania Department of Agriculture, 2007, Pennsylvania 'Ag Snapshot' 2006: Pennsylvania Agricultural Statistics 20062007, Harrisburg, Pa., 3 p.

Thelin, G.P., 2000, Method for estimating pesticide use for county areas of conterminous United States: U.S. Geological Survey Open-File Report 00-250, p. 6-16.

U.S. Department of Agriculture National Agricultural Statistics Service, 1997a, Agricultural chemical usage 1996 vegetable summary: accessed December 28, 2008, at http://usda.mannlib.cornell.edu/usda/nass/ AgriChemUsVeg/1990s/1997/AgriChemUsVeg-07-15-1997.txt

U.S. Department of Agriculture National Agricultural Statistics Service, 1997b, Pennsylvania Statistics: accessed December 28, 2008, at http://www.nass.usda.gov/Statistics_by_State/ Pennsylvania/index.asp
U.S. Department of Agriculture National Agricultural Statistics Service, 2004, Agricultural chemical usage 2003 field crops summary: Washington, D.C., p. 70.

U.S. Department of Agriculture National Agricultural Statistics Service, 2005a, Agricultural chemical usage 2004 vegetables summary: Washington, D.C., p. 77, 155.

U.S. Department of Agriculture National Agricultural Statistics Service, 2005b, Pennsylvania Statistics: accessed December 28, 2008, at http://www.nass.usda.gov/Statistics_by_Statel Pennsylvania/index.asp

U.S. Department of Agriculture National Agricultural Statistics Service, 2006a, Agricultural chemical usage 2005 field crops summary: Washington, D.C., p. 33, 68.

U.S. Department of Agriculture National Agricultural Statistics Service, 2006b, Agricultural chemical usage 2005 fruit summary: Washington, D.C., p. 32-34, 102, 156-157.

U.S. Department of Agriculture National Agricultural Statistics Service, 2006c, Pennsylvania Statistics: accessed December 28, 2008, at http://www.nass.usda.gov/Statistics_by_State/ Pennsylvania/index.asp

U.S. Department of Agriculture National Agricultural Statistics Service, 2007a, Agricultural chemical usage 2006 field crops summary: Washington, D.C., p. 38, 70.

U.S. Department of Agriculture National Agricultural Statistics Service, 2007b, Agricultural chemical usage 2006 vegetables summary: Washington, D.C., p. 37, 100. 


\section{Appendix 2. Detailed Description of Quality-Control Methods and Data Analyses}

This appendix provides detailed information on qualitycontrol methods, the analysis of quality-control sample results, and how the analyses were used to evaluate project qualityassurance (QA) objectives. For QA objectives related to bias and variability, data were presented separately for pesticides, nitrate and nitrite, and total coliform and Escherichia coli (E. coli) bacteria.

Quality-control samples were submitted to the Pennsylvania Department of Environmental Protection Laboratory (PADEPL) and three U.S. Geological Survey (USGS) laboratories - Ohio Water Microbiology Laboratory (OWML), Organic Geochemistry Research Laboratory (OGRL), and National Water Quality Laboratory (NWQL) - for QA of analytical results for well-water samples (table 2-1); the results from these samples were used to evaluate additional QA objectives.

\section{Representativeness of Sampling of Hydrogeologic Settings}

QA objective 1 (representativeness of samples) was met by adhering to well-selection criteria and USGS protocols for stability of field measurements (U.S. Geological Survey, variously dated) during well purging prior to sampling. QA goals for well selection were established using the following criteria: the wells 1) were used on a daily basis, 2) had available detailed driller information (records on file with the homeowner or Pennsylvania Topographic and Geologic Survey that would provide confirmation of well depth and aquifer lithology), 3) were not affected by point sources of contamination, 4) were not influenced by surface-water sources, 5) had storage and treatment systems that could be by-passed during well purge and sample collection, 6) were used for household or farm-water supply in an area of row crop, orchard, or vineyard land use, 7) had sufficient yield to obtain a sample representative of the aquifer, and 8) had depths of $250 \mathrm{ft}$ or less (100 ft or less for the Eastern Lake surficial setting) or had all the water-bearing zones less than $250 \mathrm{ft}$ (100 ft for the Eastern Lake surficial setting) and were cased to the primary aquifer. In 2007, the last year of the study, commercial and production wells also were considered for sampling if the land near the wells was used for row-crop agriculture. The criteria for wateruse type were expanded for several reasons: 1) to improve the number of possible wells meeting lithology criteria-wells drilled in recent years are drilled through unconsolidated sand and gravel into bedrock to improve water quality and this limited the number of household or farm wells completed in sand and gravel, 2) to improve the number of wells meeting the land-use criteria - field observations indicated that many row-crop areas were fallow, and 3) to more accurately reflect the water quality in the setting because of the higher yield of commercial and production wells.

Locating wells that would meet all eight well-selection criteria was not practical; between six and eight criteria were met for each well that was selected for sample collection. Stability criteria for field measurements were met approximately 95 percent of the time. Most wells were used every day; therefore, flushing of the well for daily household processes (bathing, laundry, etc.) was routine, and the stability of all indicators usually could be reached within 30 minutes. During the well purge at several low-yielding wells, the stability of all indicators was not reached in 30 minutes, and the sample was collected with only three to four indicators being stable.

\section{False Positives}

QA objective 2 (bias resulting from sample contamination) was evaluated through the use of equipment, trip, and field blanks. A 'blank' is a water sample intended to be free of the analytes of interest. Approximately 18 percent of the number of environmental samples were submitted as QA blanks.

Equipment blanks were collected in the Pennsylvania Water Science Center (PA WSC) laboratory by pouring blank water through the equipment used for sample collection. Certified inorganic-free blank water was used for nitrate and nitrite, organic-free blank water was used for pesticides, and autoclaved deionized water (years 2005 and 2006) or sterile phosphate buffer with peptone (years 2003 and 2004) was used for bacteria. Autoclaved deionized water, used for bacteria blanks after 2004, was the blank solution used for the Colilert-tray method. During the 5-year study, five equipment blanks were analyzed for pesticides, three equipment blanks were analyzed for nitrate and nitrite, and two equipment blanks were analyzed for total coliform and E. coli bacteria.

Trip blanks were prepared to evaluate if contamination was introduced in the transportation of samples and containers. Two trip blanks - one for nitrate and nitrite and one for total coliform and E. coli bacteria-were analyzed.

Field blanks were prepared at the well site to demonstrate that (1) equipment was adequately cleaned to remove contamination introduced by samples collected at previous sites, (2) sample collection and processing did not produce artificial contamination, and (3) sample handling and transport did not introduce contamination. In addition, because the field blank was treated like an environmental sample at the analytical laboratory, field blanks could help to identify potential contamination introduced during laboratory handling and analysis. Nine field blanks were analyzed for pesticides, 11 field blanks were analyzed for nitrate and nitrite, and 10 field blanks were analyzed for total coliform and E. coli bacteria. 
Table 2-1. Summary of quality-control samples analyzed at the U.S. Geological Survey (USGS) National Water Quality Laboratory (NWQL), USGS Ohio Water Microbiology Laboratory (OWML), the USGS Organic Geochemistry Research Laboratory (OGRL), and the Pennsylvania Department of Environmental Protection Laboratory (PADEPL), 2003-07.

[Pesticides analyzed using C-18 solid-phase extraction (SPE) and capillary-column gas chromatography/mass spectrometry with selected ion monitoring (GCMS) at the USGS NWQL are listed in table 7; pesticides analyzed using graphitized carbon-based SPE and high-performance liquid chromatography/mass spectrometry (HPLCMS) at the USGS NWQL are listed in table 8; U.S. Environmental Protection Agency (USEPA) 525.2-method USEPA 531.1-method pesticides (baseline-assessment and trends listings) are listed on table 6; pesticides analyzed by SPE and HPLCMS at the OGRL are listed on table 9; 2-lab split samples are split samples analyzed at two laboratories; E. coli, Escherichia coli]

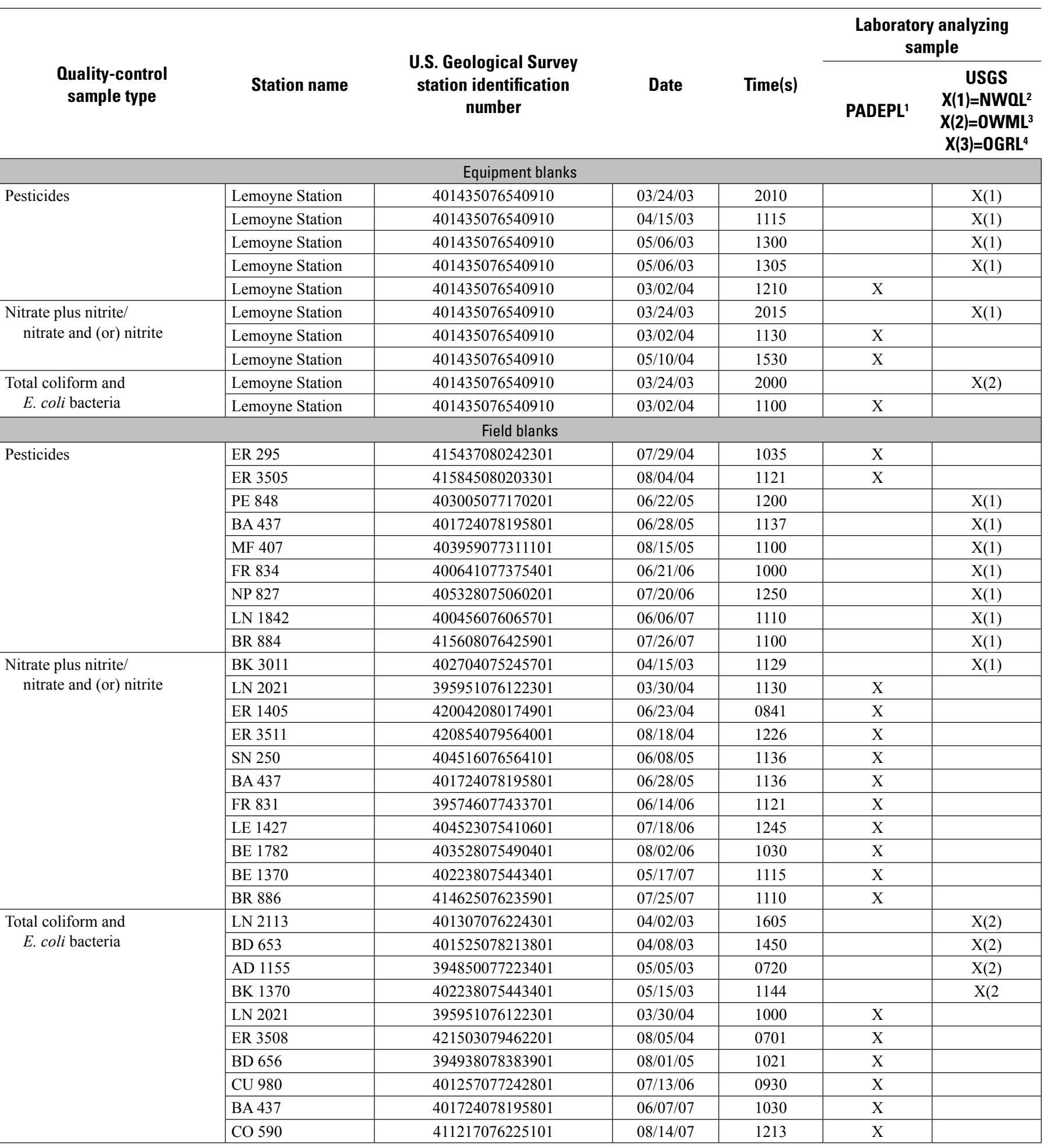


Table 2-1. Summary of quality-control samples analyzed at the U.S. Geological Survey (USGS) National Water Quality Laboratory (NWQL), USGS Ohio Water Microbiology Laboratory (OWML), the USGS Organic Geochemistry Research Laboratory (OGRL), and the Pennsylvania Department of Environmental Protection Laboratory (PADEPL), 2003-07.-Continued

[Pesticides analyzed using C-18 solid-phase extraction (SPE) and capillary-column gas chromatography/mass spectrometry with selected ion monitoring (GCMS) at the USGS NWQL are listed in table 7; pesticides analyzed using graphitized carbon-based SPE and high-performance liquid chromatography/mass spectrometry (HPLCMS) at the USGS NWQL are listed in table 8; U.S. Environmental Protection Agency (USEPA) 525.2-method USEPA 531.1-method pesticides (baseline-assessment and trends listings) are listed on table 6; pesticides analyzed by SPE and HPLCMS at the OGRL are listed on table 9; 2-lab split samples are split samples analyzed at two laboratories; E. coli, Escherichia coli]

\begin{tabular}{|c|c|c|c|c|c|c|}
\hline \multirow[b]{2}{*}{$\begin{array}{l}\text { Quality-control } \\
\text { sample type }\end{array}$} & \multirow[b]{2}{*}{ Station name } & \multirow[b]{2}{*}{$\begin{array}{c}\text { U.S. Geological Survey } \\
\text { station identification } \\
\text { number }\end{array}$} & \multirow[b]{2}{*}{ Date } & \multirow[b]{2}{*}{ Time(s) } & \multicolumn{2}{|c|}{$\begin{array}{c}\text { Laboratory analyzing } \\
\text { sample }\end{array}$} \\
\hline & & & & & PADEPL ${ }^{1}$ & $\begin{array}{c}\text { USGS } \\
X(1)=N W Q L^{2} \\
X(2)=0 \text { WML }^{3} \\
X(3)=0 \mathrm{GRL}^{4}\end{array}$ \\
\hline \multicolumn{7}{|c|}{ Trip blanks } \\
\hline $\begin{array}{c}\text { Total coliform and } \\
\text { E. coli bacteria }\end{array}$ & AD 1155 & 394850077223401 & $05 / 05 / 03$ & 1100 & & $\mathrm{X}(2)$ \\
\hline \multicolumn{7}{|c|}{ Replicates } \\
\hline \multirow[t]{7}{*}{$\begin{array}{l}\text { Nitrate plus nitrite/ } \\
\text { nitrate and (or) nitrite }\end{array}$} & LY 686 & 410805077131401 & $04 / 30 / 03$ & $\begin{array}{l}1211 \\
1212 \\
\end{array}$ & & $\mathrm{X}(1)$ \\
\hline & PE 847 & 402122077131601 & $06 / 08 / 05$ & $\begin{array}{l}0841 \\
0842\end{array}$ & $\mathrm{X}$ & \\
\hline & NU 570 & 410604076493401 & $06 / 21 / 05$ & $\begin{array}{l}0946 \\
0947\end{array}$ & $\mathrm{X}$ & \\
\hline & FR 833 & 395117077464001 & $06 / 20 / 06$ & $\begin{array}{l}1123 \\
1124\end{array}$ & $\mathrm{X}$ & \\
\hline & CU 981 & 401506077195701 & $07 / 27 / 06$ & $\begin{array}{l}1150 \\
1155\end{array}$ & $\mathrm{X}$ & \\
\hline & BA 437 & 401724078195801 & $05 / 15 / 07$ & $\begin{array}{l}1208 \\
1209 \\
\end{array}$ & $\mathrm{X}$ & \\
\hline & LY 690 & 411155076432501 & $05 / 30 / 07$ & $\begin{array}{l}1421 \\
1422\end{array}$ & $\mathrm{X}$ & \\
\hline
\end{tabular}


Table 2-1. Summary of quality-control samples analyzed at the U.S. Geological Survey (USGS) National Water Quality Laboratory (NWQL), USGS Ohio Water Microbiology Laboratory (OWML), the USGS Organic Geochemistry Research Laboratory (OGRL), and the Pennsylvania Department of Environmental Protection Laboratory (PADEPL), 2003-07.—Continued

[Pesticides analyzed using C-18 solid-phase extraction (SPE) and capillary-column gas chromatography/mass spectrometry with selected ion monitoring (GCMS) at the USGS NWQL are listed in table 7; pesticides analyzed using graphitized carbon-based SPE and high-performance liquid chromatography/mass spectrometry (HPLCMS) at the USGS NWQL are listed in table 8; U.S. Environmental Protection Agency (USEPA) 525.2-method USEPA 531.1-method pesticides (baseline-assessment and trends listings) are listed on table 6; pesticides analyzed by SPE and HPLCMS at the OGRL are listed on table 9; 2-lab split samples are split samples analyzed at two laboratories; E. coli, Escherichia coli]

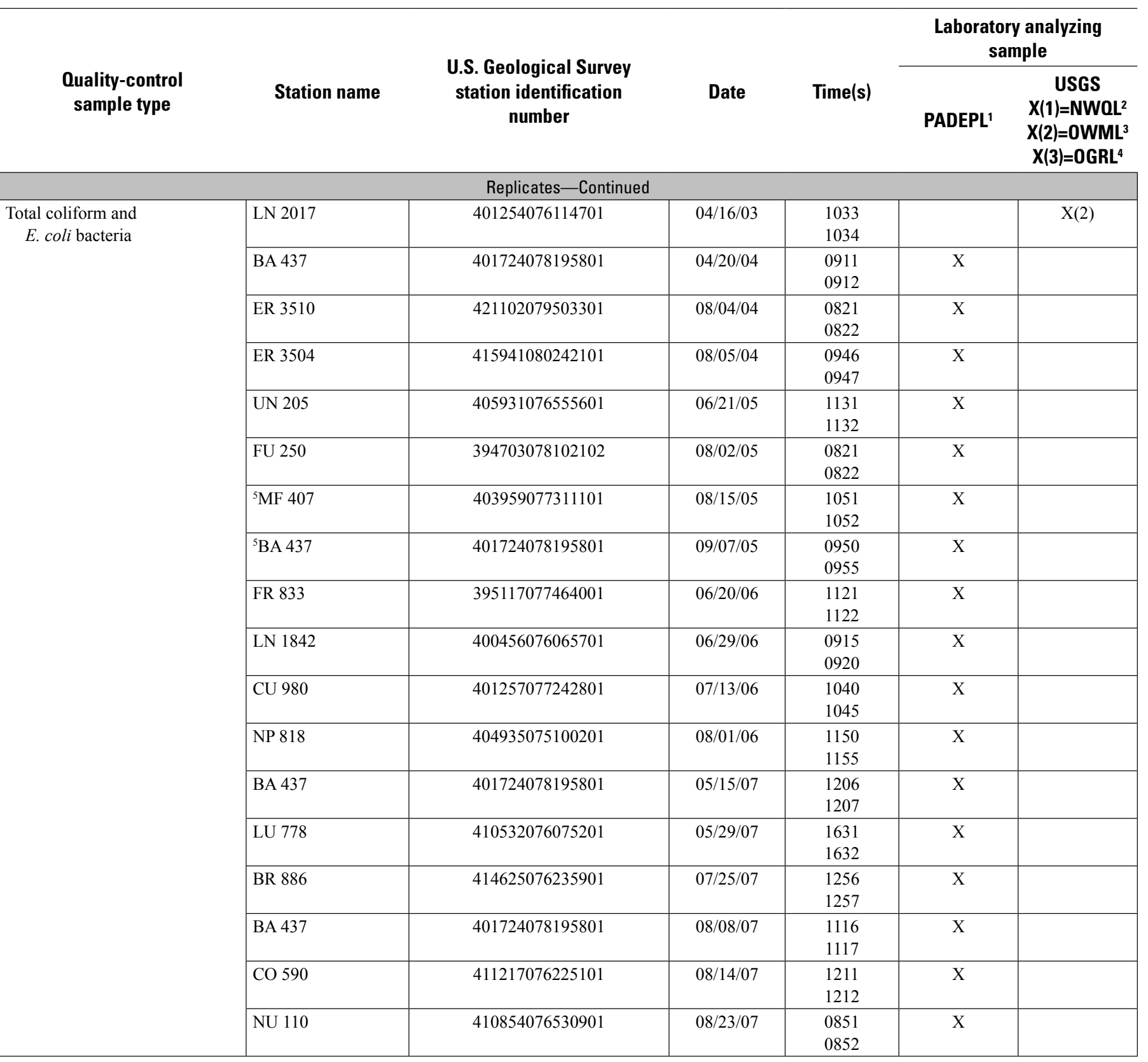


Table 2-1. Summary of quality-control samples analyzed at the U.S. Geological Survey (USGS) National Water Quality Laboratory (NWQL), USGS Ohio Water Microbiology Laboratory (OWML), the USGS Organic Geochemistry Research Laboratory (OGRL), and the Pennsylvania Department of Environmental Protection Laboratory (PADEPL), 2003-07.-Continued

[Pesticides analyzed using C-18 solid-phase extraction (SPE) and capillary-column gas chromatography/mass spectrometry with selected ion monitoring (GCMS) at the USGS NWQL are listed in table 7; pesticides analyzed using graphitized carbon-based SPE and high-performance liquid chromatography/mass spectrometry (HPLCMS) at the USGS NWQL are listed in table 8; U.S. Environmental Protection Agency (USEPA) 525.2-method USEPA 531.1-method pesticides (baseline-assessment and trends listings) are listed on table 6; pesticides analyzed by SPE and HPLCMS at the OGRL are listed on table 9; 2-lab split samples are split samples analyzed at two laboratories; E. coli, Escherichia coli]

\section{Quality-control sample type}

Station name

\section{U.S. Geological Survey station identification} number
Laboratory analyzing sample

\begin{tabular}{cc}
\multicolumn{2}{c}{ sample } \\
\hline & USGS \\
& $X(1)=N W 0 L^{2}$ \\
PADEPL $^{1}$ & \\
& $X(2)=\mathrm{OWML}^{3}$ \\
& $\mathrm{X}(3)=0 \mathrm{GRL}^{4}$
\end{tabular}

\begin{tabular}{|c|c|c|c|c|c|}
\hline \multicolumn{6}{|c|}{ Field-spiked (pesticides) reagent water samples, prepared in triplicate } \\
\hline Lemoyne Station & 401435076540910 & $04 / 15 / 03$ & $\begin{array}{l}1120 \\
1121 \\
1122\end{array}$ & & $\mathrm{X}(1)$ \\
\hline Lemoyne Station & 401435076540910 & $05 / 06 / 03$ & $\begin{array}{l}1240 \\
1241 \\
1242\end{array}$ & & $\mathrm{X}(1)$ \\
\hline Lemoyne Station & 401435076540910 & $05 / 06 / 03$ & $\begin{array}{l}1243 \\
1244 \\
1245 \\
\end{array}$ & & $\mathrm{X}(1)$ \\
\hline Lemoyne Station & 401435076540910 & $08 / 27 / 03$ & $\begin{array}{l}1100 \\
1105 \\
1110\end{array}$ & $\mathrm{X}$ & \\
\hline Lemoyne Station & 401435076540910 & $04 / 21 / 04$ & $\begin{array}{l}0900 \\
0905 \\
0910\end{array}$ & $\mathrm{X}$ & \\
\hline Lemoyne Station $^{6}$ & 401435076540910 & $06 / 08 / 04$ & $\begin{array}{l}1300 \\
1305 \\
1310 \\
1315 \\
1320 \\
1325\end{array}$ & $\mathrm{X}$ & \\
\hline Lemoyne Station $^{6}$ & 401435076540910 & $07 / 21 / 04$ & $\begin{array}{l}1250 \\
1255 \\
1300 \\
1305 \\
1310 \\
1315\end{array}$ & $\mathrm{X}$ & \\
\hline Lemoyne Station $^{6}$ & 401435076540910 & $05 / 24 / 05$ & $\begin{array}{l}1030 \\
1040 \\
1050 \\
\end{array}$ & & $\mathrm{X}(1)$ \\
\hline Lemoyne Station & 401435076540910 & $06 / 21 / 05$ & $\begin{array}{l}1020 \\
1030 \\
1040\end{array}$ & & $\mathrm{X}(1)$ \\
\hline \begin{tabular}{|l|} 
Lemoyne Station \\
\end{tabular} & 401435076540910 & $08 / 08 / 05$ & $\begin{array}{l}1100 \\
1105 \\
1110 \\
\end{array}$ & & $\mathrm{X}(1)$ \\
\hline
\end{tabular}


Table 2-1. Summary of quality-control samples analyzed at the U.S. Geological Survey (USGS) National Water Quality Laboratory (NWQL), USGS Ohio Water Microbiology Laboratory (OWML), the USGS Organic Geochemistry Research Laboratory (OGRL), and the Pennsylvania Department of Environmental Protection Laboratory (PADEPL), 2003-07.—Continued

[Pesticides analyzed using C-18 solid-phase extraction (SPE) and capillary-column gas chromatography/mass spectrometry with selected ion monitoring (GCMS) at the USGS NWQL are listed in table 7; pesticides analyzed using graphitized carbon-based SPE and high-performance liquid chromatography/mass spectrometry (HPLCMS) at the USGS NWQL are listed in table 8; U.S. Environmental Protection Agency (USEPA) 525.2-method USEPA 531.1-method pesticides (baseline-assessment and trends listings) are listed on table 6; pesticides analyzed by SPE and HPLCMS at the OGRL are listed on table 9; 2-lab split samples are split samples analyzed at two laboratories; E. coli, Escherichia coli]

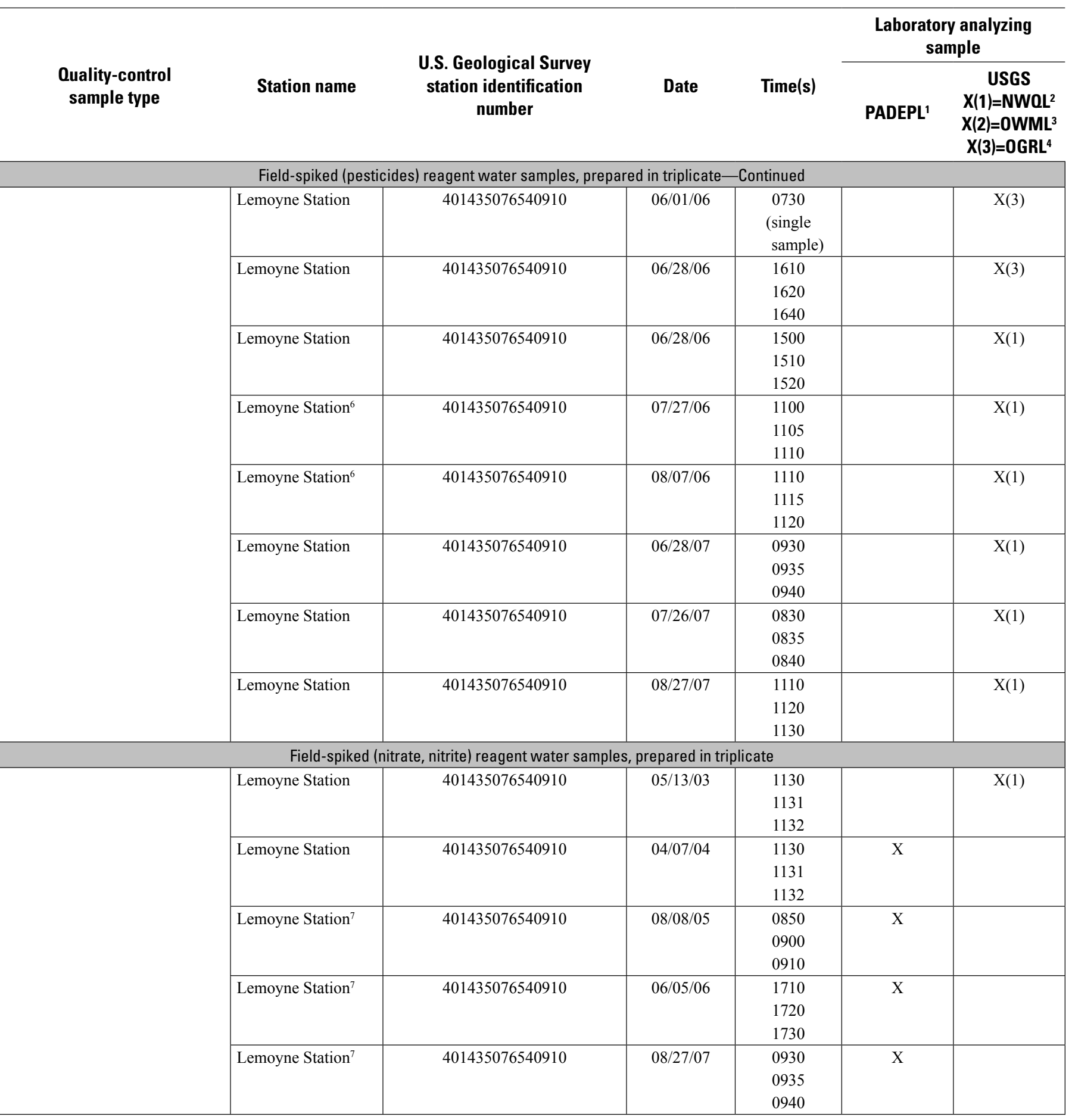


Table 2-1. Summary of quality-control samples analyzed at the U.S. Geological Survey (USGS) National Water Quality Laboratory (NWQL), USGS Ohio Water Microbiology Laboratory (OWML), the USGS Organic Geochemistry Research Laboratory (OGRL), and the Pennsylvania Department of Environmental Protection Laboratory (PADEPL), 2003-07.-Continued

[Pesticides analyzed using C-18 solid-phase extraction (SPE) and capillary-column gas chromatography/mass spectrometry with selected ion monitoring (GCMS) at the USGS NWQL are listed in table 7; pesticides analyzed using graphitized carbon-based SPE and high-performance liquid chromatography/mass spectrometry (HPLCMS) at the USGS NWQL are listed in table 8; U.S. Environmental Protection Agency (USEPA) 525.2-method USEPA 531.1-method pesticides (baseline-assessment and trends listings) are listed on table 6; pesticides analyzed by SPE and HPLCMS at the OGRL are listed on table 9; 2-lab split samples are split samples analyzed at two laboratories; E. coli, Escherichia coli]

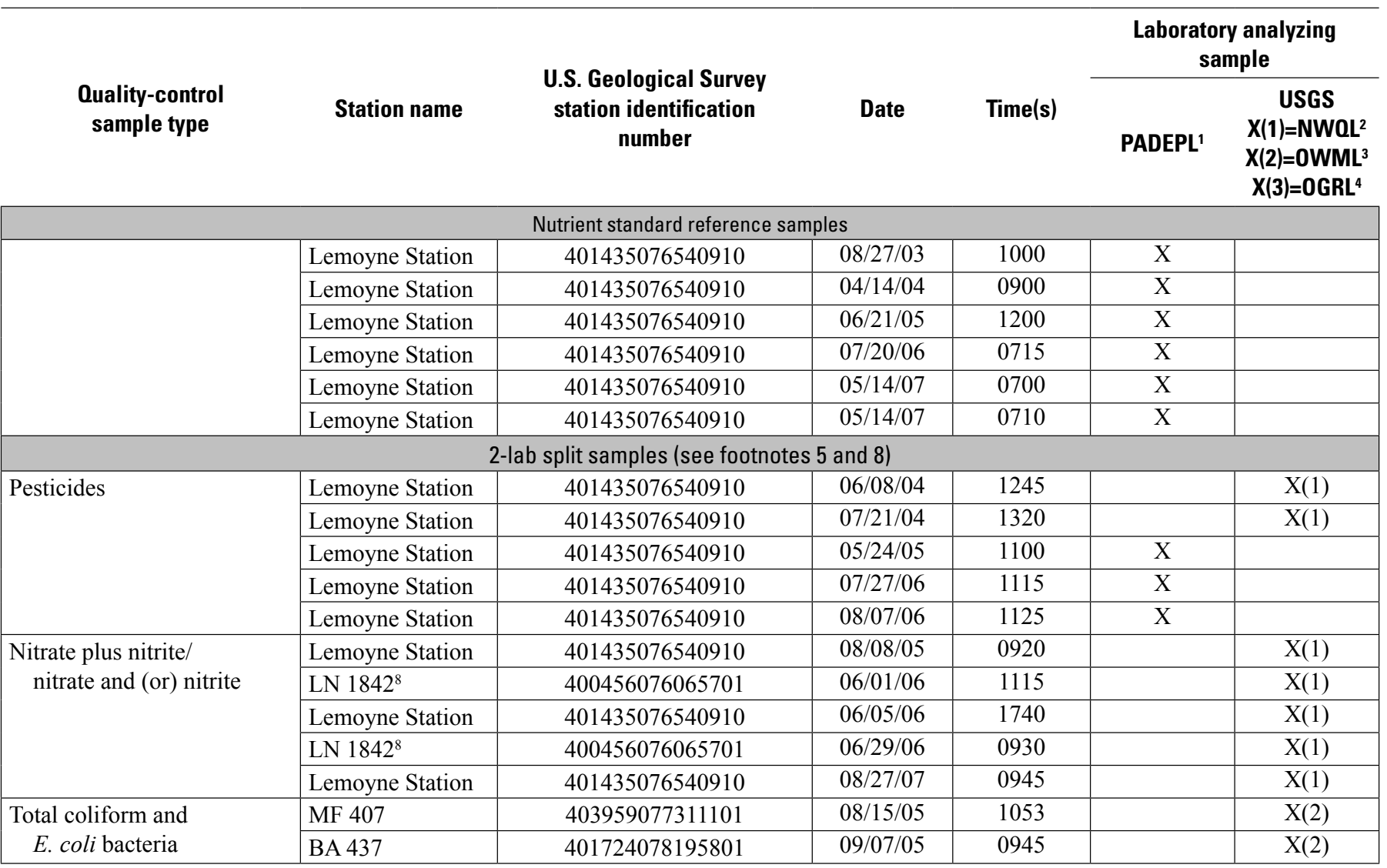

${ }^{1}$ Methodologies used at the PADEPL: nitrate and nitrite, cadmium reduction of nitrate to nitrite followed by colorimetry (nitrate-N and nitrite-N); pesticides, USEPA 525.2 method, SPE and GCMS (listing analyzed for trends assessments) or USEPA 525.2 method, SPE and GCMS and USEPA 531.1 method, direct aqueous injection into a reverse phase high-performance liquid chromatography (HPLC) column with post column derivitazation and fluorescence detection (listing analyzed for baseline-assessments); bacteria, Colilert tray.

${ }^{2}$ Methodologies used at the USGS NWQL: nitrate plus nitrite, Cadmium reduction of nitrate to nitrite followed by colorimetry (nitrate plus nitrite- nitrogen (N) and nitrite-N); pesticides, C-18 SPE and capillary-column GCMS with selected-ion monitoring; May 6, 2003 @ 1305 sample only, graphitized carbon-based SPE and high-performance HPLCMS.

${ }^{3}$ Methodology used at USGS OWML: bacteria, Colilert tray.

${ }^{4}$ Methodology used at USGS OGRL: pesticides, SPE and HPLCMS.

${ }^{5}$ An additional split-environmental sample was collected and submitted to the OWML to verify reported values received from PADEPL; this sample is listed under the 2-lab-split sample heading of this table (same station name and date, different time).

${ }^{6}$ An additional field-spiked reagent water sample was prepared and submitted to either the PADEPL or the NWQL to verify reported values received from the primary laboratory (see table 5) at the time of sample collection; this sample is listed under the 2-lab-split sample heading of this table (same station name and date, different time).

${ }^{7}$ An additional field-spiked reagent water sample was prepared and submitted to the NWQL to verify reported values for samples analyzed at the PADEPL; this sample is listed under the 2-lab-split sample heading of this table (same station name and date, different time).

${ }^{8} \mathrm{~A}$ split-environmental sample sent to the NWQL to verify reported values for samples analyzed at the PADEPL. 


\section{False Negatives}

False negatives (QA objective 3) occur when known concentrations of analytes are not detected. Potential falsenegative results were evaluated mainly through the use of field-spiked reagent water (FSRW) samples (pesticides and nitrate and nitrite), USGS Branch of Quality Systems standard reference water samples (SRWS) (used for nitrate and nitrite only), and, to a lesser degree, samples analyzed at two laboratories (2-lab splits). Approximately 33 percent of the number of environmental samples were submitted as spikes. A spike is a sample prepared from either environmental or reagent-grade water fortified with a known mass of the analyte of interest; for this study, only reagent-water spikes were used.

For pesticides, no false negatives were reported for 64 of the 65 compounds (surrogates not included in count) in 58 FSRW samples and five 2-lab splits. Sixty of the 65 pesticides were included in FSRW samples analyzed at the NWQL; 15 of the 60 pesticides analyzed at the NWQL in FSRW samples were also submitted in QC samples analyzed at the PADEPL. Five additional pesticides - captan, hexachlorocyclopentadiene, phosphamidon, chlorothalonil, and diuron-were included in FSRW samples analyzed only at the PADEPL. Captan was the only compound in two sets of triplicate spikes submitted to the PADEPL that was not reported in any of the six samples. The internal QC sample recoveries at the PADEPL were evaluated and found to be within an acceptable range. The manufacturer of the spike solution was contacted to determine if captan was mistakenly not included in the spike solution; all internal records indicated that captan was included in the spike mixture as requested. The source of the problem (false negatives for captan) was not apparent through any communications with the spike manufacturer or the laboratory. The false negatives for captan could not be verified with 2-lab splits because samples analyzed at the NWQL did not include captan. Captan was not detected in any environmental samples analyzed at the PADEPL.

\section{Bias and Variability}

Estimates of bias and variability in reported concentrations using field-submitted and laboratory QC samples for analyses of nitrate, nitrite, total coliform and E. coli bacteria, and pesticides analyzed at the PADEPL, USGS NWQL, and the USGS OWML are shown in table 2-2 (at back of appendix). Pesticide-recovery results for a single FSRW sample and a set of triplicate FSRW samples sent to the USGS OGRL in June 2006 using a USGS-certified spike mixture of pesticides and herbicides are shown in table 2-3.

Magnitude of the departure from a 'true' or known sample concentrations (called 'bias') was estimated from spikedsample results by calculating the percentage of the added analyte recovered in the sample (Friedman and Erdmann, 1982). Recovery can be either greater than or less than 100 percent, so the bias can be either positive or negative. Recovery results from SRWS and triplicate FSRW samples (nitrate and nitrite) and triplicate FSRW samples (pesticides) were used primarily to evaluate QA objective 4 goals; however, if compounds were not included in SRWS or FSRW samples, lab-reagent spike (LRS) data were used for estimates of bias in recoveries. The bias estimates (table 2-2) do not include the effect of environmental water matrices, which were not evaluated during this project.

Variability is the degree of random error in independent measurements of the same quantity, or more simply stated, how "tightly" concentrations of compounds can be reported for identical samples whether they are environmental samples, spikes, or reference samples. Information on variability can be used to estimate the reproducibility of individual measurements, the concentration needed to be assured of exceeding a water-quality standard, and the likelihood that two measurements of water quality are different. One method to estimate variability related to FSRW, SRWS, and LRS recoveries used a nonparametric statistic termed F-pseudosigma. F-pseudosigma is defined as the interquartile range of data divided by 1.349 (Hoaglin and others, 1983). F-pseudosigmas were calculated using aggregated recoveries of individual compounds in field-submitted SRWS and triplicate FSRW samples (nitrate and nitrite) and triplicate FSRW samples (pesticides) over the course of the project. For those pesticides not included in FSRW samples, F-pseudosigmas were calculated using recoveries from LRS to provide an estimate of analytical variability.

Variability also was determined using a second method that included the calculation of Relative Standard Deviation (RSD) (Friedman and Erdmann, 1982). RSD measures differences between concentrations of triplicate samples and is computed as follows:

$$
R S D=\frac{S D \text { of triplicate concentrations }}{\text { mean concentration of triplicate results }} \times 100
$$

where

$R S D$ is relative standard deviaion, in percent, and $S D$ is standard deviation.

RSDs were first calculated using concentrations from individual sets of quality-control samples: results from triplicate environmental replicates and FSRW samples (nitrate and nitrite), triplicate environmental replicates (total coliform and $E$. coli bacteria), and triplicate FSRW samples (pesticides) were used. The median RSD was then calculated using the RSDs from individual sets of triplicate results for each compound. Results for F-pseudosigma from aggregated compound recoveries (method 1) and also median RSDs from concentrations in triplicate field-submitted samples (method 2) were primarily used to evaluate if variability in reported data was within 25 percent (QA objective 5). The variability estimates in pesticide results noted in table 2-2 do not include the effect of environmental water matrices, which were not evaluated during this project. 


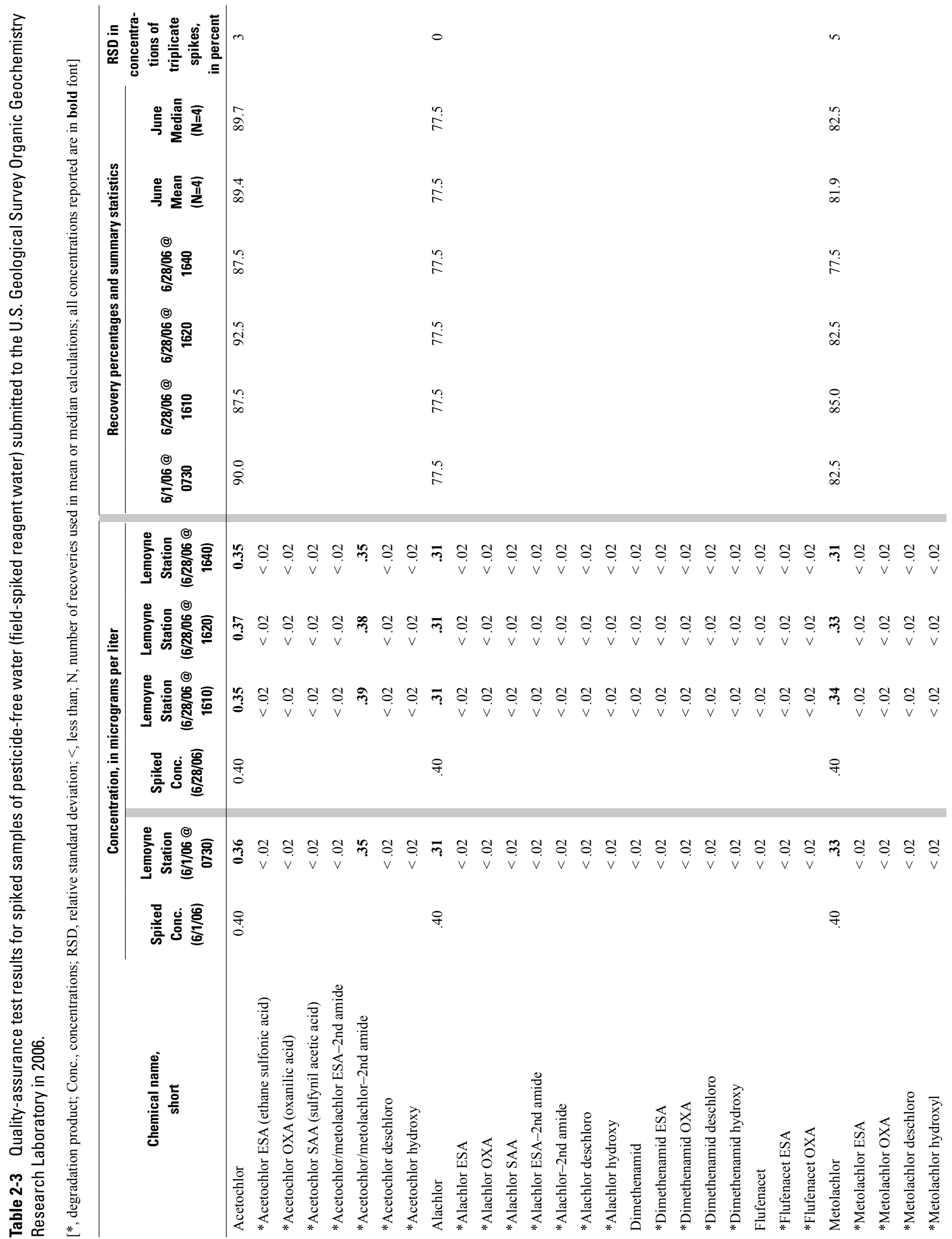




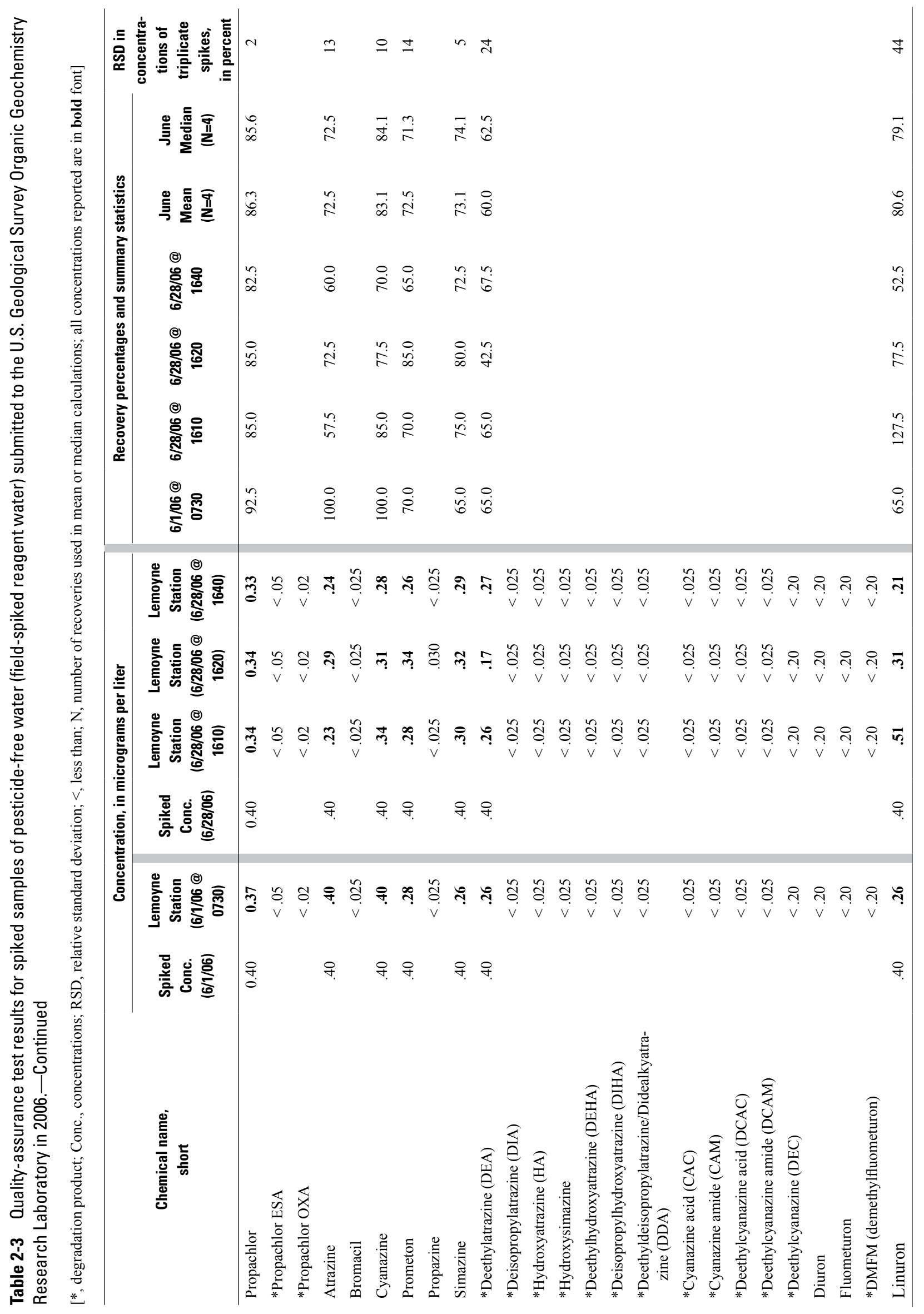




\section{Pesticides}

Most of the FSRW samples were submitted in triplicate so that bias and variability of results could be determined with each set of quality-control samples. For May 2003 and 2005-07, the pesticide-spike solutions used were Supelco or NWQL-prepared, USGS-certified mixtures of pesticides and herbicides. ULTRA Scientific custom-spike mixtures were used August 2003 and during 2004 to evaluate compounds not available in USGS-certified spike solutions. Spike solutions were prepared in the PA WSC laboratory using a micropipette to create solutions with concentrations of $0.4 \mu \mathrm{g} / \mathrm{L}$ for the targeted analytes, except for carbaryl, oxamyl, and methomyl spikes analyzed in 2003 and 2004. During this time, separate triplicate pesticide-spiked samples for carbaryl, oxamyl, and methomyl were prepared using a commercially available mixture of pesticides diluted to a concentration of $3.2 \mu \mathrm{g} / \mathrm{L}$. These samples were intended to be analyzed at the PADEPL where the minimum reporting levels (MRLs) for these compounds were $2.0 \mu \mathrm{g} / \mathrm{L}$, but they were actually analyzed at both the PADEPL and the NWQL.

The pesticide-spike concentration of $0.4 \mu \mathrm{g} / \mathrm{L}$ was selected to evaluate bias near action levels defined by Pennsylvania Pesticides and Ground Water Strategy (Pennsylvania Department of Agriculture, 1998) and to approximate concentrations in ground water analyzed in previous studies, summarized in Lindsey and Bickford (1999). Action levels for pesticides (Pennsylvania Department of Agriculture, 1998) are invoked by the PDA at fractions of the U.S. Environmental Protection Agency (USEPA) maximum contaminant levels (MCLs) or lifetime health advisories (LHAs) (appendix 4).

Analysis of recovery of pesticides spiked into water was used to assess bias of results. Pesticide recoveries, in percent, were calculated using the following formula:

\section{$\frac{\text { Lab-reported concentration }}{\text { Known concentration }} \times 100$}

where,

Lab-reported concentration is the concentration that the NWQL or PADEPL measured for each pesticide in the FSRW sample in micrograms per liter, and

Known concentration is the spike concentration prepared at the PA WSC laboratory, in micrograms per liter.

Methodology for determining the known concentration of each compound in the spike solution is available from the NWQL (U.S. Geological Survey, 1996). Because certified, analyte-free (reagent) water was used for all spikes, it was assumed that no analytes of interest were contributed from the water used to make the spike solution.

To evaluate bias in recovery for pesticides, median recoveries (in percent) from two data sets were used: 1) triplicate FSRW samples, and 2) lab internal quality-control samples. For the 65 pesticides included in spike mixtures used for this project (table 2-2), median recoveries of pesticides in FSRW samples were calculated from recovery results from samples analyzed at the USGS NWQL and separately for samples analyzed at the PADEPL. Median pesticide recoveries were calculated using recoveries from 3 to 33 samples depending on the compound and laboratory.

Using lab internal quality-control sample data, median recoveries from LRS recovery data were used in two ways: 1) for comparison only - to FSRW sample median recoveries (calculated for 65 pesticides), and 2) as the sole indicator of the performance in recovery of the compound, if the pesticide was not included in the spikes submitted (50 pesticides, table 2-2). USGS LRS median recoveries (table 2-2) are based on data compiled from 2002 to 2006 for a suite of pesticides (table 2-4); statistics were based on 968 to 1,417 spike results, depending on the specific compound. USGS LRS median recoveries for another suite of pesticides (table 2-5) were based on data compiled from February 2002 to February 2003 using approximately 235 spike results. PADEPL LRS median recoveries for compounds analyzed by USEPA 525.2 method (table 2-6) were calculated from recovery information from between 5 and 17 LRS. Because LRS samples were not analyzed for the USEPA 531.1 method (table 2-6) at the PADEPL, carbaryl, oxamyl, and methomyl recoveries from lab-spiked environmental samples were used as estimates of method performance, assuming LRS would give recoveries closer to 100 percent in the absence of the effects of environmental water.

Additional detail on internal quality control at the USGS NWQL and OGRL can be found in Zaugg and others (1995), Madsen and others (2003), Furlong and others (2001), Lee and others (2002), and Lee and Strahan (2003). Detail on internal quality control for methods USEPA 531.1 (carbamates) and USEPA 525.2 (semi-volatiles and pesticides) is available as Standard Operating Procedures on file at the PADEPL QA office (James Yoder, Pennsylvania Department of Environmental Protection Laboratory, QA Section Chief, oral commun., February 4, 2008).

\section{Nitrate and Nitrite}

For nitrate and nitrite, analytical laboratories have established internal quality-control samples to monitor method performance. Results from internal spiked samples are compared to acceptance criteria to decide if the spiked sample should be re-analyzed or if a comment should be added to the result noting that the quality-control criteria were not met. Details on internal quality control for the nitrate and nitrite methodology used at the NWQL are found in Fishman (1993). Similar detail for internal control for methodology used at the PADEPL is available as a Standard Operating Procedure (USEPA 353.2Automated Colorimetry) on file at the PADEPL QA office (James Yoder, Pennsylvania Department of Environmental Protection Laboratory, QA Section Chief, oral commun., February 4,2008 ).

To evaluate bias in reported data, 15 FSRW samples for nitrate and nitrite were prepared using Spex CertiPrep 
Table 2-4. Pesticides analyzed using C-18 solid-phase extraction and capillary-column gas chromatography/mass spectrometry with selected-ion monitoring at the U.S. Geological Survey National Water-Quality Laboratory in Denver, Colorado, from March to May 2003 and May 2005 to September 2007.

[NWIS, National Water Information System; bolding of compound names denotes all values are estimated because of low recoveries or high variability in lab reagent spikes; pct, percent; NA, not available]

\begin{tabular}{|c|c|c|c|c|c|c|c|}
\hline Compound & $\begin{array}{c}\text { NWIS } \\
\text { parameter } \\
\text { code }\end{array}$ & $\begin{array}{l}\text { Minimum } \\
\text { reporting } \\
\text { level, } \\
\text { in } \\
\text { micrograms } \\
\text { per liter }\end{array}$ & $\begin{array}{l}\text { Method } \\
\text { detection } \\
\text { limit, } \\
\text { in } \\
\text { micrograms } \\
\text { per liter }\end{array}$ & Compound & $\begin{array}{c}\text { NWIS } \\
\text { parameter } \\
\text { code }\end{array}$ & $\begin{array}{l}\text { Minimum } \\
\text { reporting } \\
\text { level, } \\
\text { in } \\
\text { micrograms } \\
\text { per liter }\end{array}$ & $\begin{array}{l}\text { Method } \\
\text { detection } \\
\text { limit, } \\
\text { in } \\
\text { micrograms } \\
\text { per liter }\end{array}$ \\
\hline 2,6-Diethylaniline & 82660 & $0.002-0.006$ & $0.001-0.003$ & Metolachlor & 39415 & $0.006-0.013$ & $0.003-0.006$ \\
\hline alpha-HCH ${ }^{1}$ & 34253 & $0.002-0.005$ & $0.001-0.002$ & Metribuzin & 82630 & $0.006-0.028$ & $0.003-0.014$ \\
\hline Acetochlor & 49260 & 0.006 & 0.003 & Napropamide & 82684 & $0.007-0.018$ & $0.003-0.009$ \\
\hline Alachlor & 46342 & $0.005-0.006$ & $0.002-0.003$ & Parathion & 39542 & 0.010 & 0.005 \\
\hline Atrazine & 39632 & 0.007 & 0.004 & Parathion-methyl & 82667 & $0.008-0.015$ & $0.004-0.008$ \\
\hline Deethylatrazine (CIAT) ${ }^{2}$ & 04040 & $0.006-0.014$ & $0.003-0.007$ & Pebulate & 82669 & $0.004-0.0041$ & $0.002-0.0021$ \\
\hline Azinphos-methyl & 82686 & $0.05-0.08$ & $0.02-0.04$ & Pendimethalin & 82683 & $0.02-0.022$ & $0.01-0.011$ \\
\hline Carbofuran & 82674 & $0.020-0.02$ & $0.010-0.01$ & Propachlor & 04024 & $0.010-0.025$ & $0.0048-0.012$ \\
\hline Chlorpyrifos & 38933 & 0.005 & 0.003 & Propanil & 82679 & 0.011 & 0.005 \\
\hline cis-Permethrin & 82687 & $0.006-0.01$ & $0.003-0.005$ & Propargite & 82685 & $0.02-0.023$ & $0.01-0.011$ \\
\hline Cyanazine & 04041 & 0.018 & 0.009 & Propyzamide & 82676 & $0.004-0.0041$ & $0.002-0.0021$ \\
\hline Dacthal (DCPA) ${ }^{3}$ & 82682 & $0.0030-0.003$ & $0.0015-0.002$ & Simazine & 04035 & $0.005-0.006$ & $0.002-0.003$ \\
\hline Desulfinylfipronil & 62170 & $0.004-0.012$ & 0.006 & Tebuthiuron & 82670 & 0.016 & 0.008 \\
\hline Desulfinylfipronil amide & 62169 & $0.009-0.029$ & 0.015 & Terbacil & 82665 & $0.034-0.04$ & $0.017-0.02$ \\
\hline Diazinon & 39572 & 0.005 & 0.003 & Terbufos & 82675 & $0.012-0.017$ & $0.006-0.009$ \\
\hline Diazinon-d10 (surrogate) & 91063 & $0.1 \mathrm{pct}$ & NA & Thiobencarb & 82681 & $0.0048-0.01$ & $0.0024-0.005$ \\
\hline Fipronil sulfide & 62167 & $0.005-0.013$ & 0.006 & & & & \\
\hline Fipronil sulfone & 62168 & $0.005-0.024$ & 0.012 & & & & \\
\hline Fonofos & 04095 & $0.0027-0.006$ & $0.0013-0.003$ & & & & \\
\hline Lindane & 39341 & $0.0040-0.004$ & $0.0020-0.002$ & & & & \\
\hline Linuron & 82666 & $0.035-0.06$ & $0.018-0.03$ & & & & \\
\hline Malathion & 39532 & $0.016-0.027$ & $0.008-0.014$ & & & & \\
\hline
\end{tabular}

${ }^{1}$ Alpha hexachlorocyclohexane.

${ }^{2}$ 2-chloro-4-isopropylamino-6-amino-s-triazine.

${ }^{3}$ Dimethyl-2,3,5,6-tetrachlorobenzene-1,4-dicarboxylic acid.

${ }^{4}$ S-ethyl dipropylthiocarbamate.

${ }^{5}$ p,p'-dichlorodiphenyldichloroethylene. 
Table 2-5. Pesticides analyzed using graphitized carbon-based solid-phase extraction and high-performance liquid chromatography/ mass spectrometry at the U.S. Geological Survey National Water-Quality Laboratory in Denver, Colorado, in May 2003.

[NWIS, National Water Information System; bolding of compound names denotes permanently estimated values in May 2003 resulting from low recoveries or high variability in lab reagent spikes; pct, percent; NA, not available; these compounds were analyzed for 10 samples collected for the baseline assessment of the Blue Ridge crystalline and Triassic Lowland siliciclastic hydrogeologic setting]

\begin{tabular}{|c|c|c|c|c|c|c|c|}
\hline Compound & $\begin{array}{c}\text { NWIS } \\
\text { Parameter } \\
\text { Code }\end{array}$ & $\begin{array}{l}\text { Minimum } \\
\text { reporting } \\
\text { level, } \\
\text { in } \\
\text { micrograms per } \\
\text { liter }\end{array}$ & $\begin{array}{l}\text { Method } \\
\text { detection } \\
\text { limit, in } \\
\text { micrograms } \\
\text { per liter }\end{array}$ & Compound & $\begin{array}{c}\text { NWIS } \\
\text { Parameter } \\
\text { Code }\end{array}$ & $\begin{array}{l}\text { Minimum } \\
\text { reporting } \\
\text { level, } \\
\text { in } \\
\text { micrograms per } \\
\text { liter }\end{array}$ & $\begin{array}{l}\text { Method } \\
\text { detection } \\
\text { limit, in } \\
\text { micrograms } \\
\text { per liter }\end{array}$ \\
\hline 2,4,5-T (surrogate) & 99958 & $0.1 \mathrm{pct}$ & $0.1 \mathrm{pct}$ & Diphenamid & 04033 & 0.0264 & NA \\
\hline $2,4-\mathrm{D}^{1}$ & 39732 & .0218 & NA & Diuron & 49300 & .015 & NA \\
\hline 2,4-D methyl ester & 50470 & .0086 & NA & Fenuron & 49297 & .0316 & NA \\
\hline $2,4-\mathrm{DB}^{2}$ & 38746 & .016 & NA & Flumetsulam & 61694 & .011 & NA \\
\hline 3(4-Chlorophenyl)-1-methyl urea & 61692 & .0242 & NA & Fluometuron & 38811 & .031 & NA \\
\hline Acifluorfen & 49315 & .0066 & NA & Imazaquin & 50356 & .016 & NA \\
\hline Aldicarb & 49312 & .04 & NA & Imazethapyr & 50407 & .017 & NA \\
\hline Aldicarb sulfone & 49313 & .02 & NA & Imidacloprid & 61695 & .0068 & NA \\
\hline Aldicarb sulfoxide & 49314 & .0082 & NA & Linuron & 38478 & .0144 & NA \\
\hline Atrazine & 39632 & .009 & NA & $\mathrm{MCPA}^{7}$ & 38482 & .0162 & NA \\
\hline 2-Hydroxyatrazine (OIET) ${ }^{3}$ & 50355 & .008 & NA & $\mathrm{MCPB}^{8}$ & 38487 & .015 & NA \\
\hline Deethylatrazine (CIAT) ${ }^{4}$ & 04040 & .0282 & NA & Metalaxyl & 50359 & .02 & NA \\
\hline Deethyldeisopropylatrazine (CAAT) ${ }^{5}$ & 04039 & .01 & NA & Methiocarb & 38501 & .008 & NA \\
\hline Deisopropylatrazine (CEAT) ${ }^{6}$ & 04038 & .044 & NA & Methomyl & 49296 & .0044 & NA \\
\hline Barban (surrogate) & 90640 & $.1 \mathrm{pct}$ & $.1 \mathrm{pct}$ & Metsulfuron methyl & 61697 & .025 & NA \\
\hline Bendiocarb & 50299 & .0252 & NA & Neburon & 49294 & .012 & NA \\
\hline Benomyl & 50300 & .0038 & NA & Nicosulfuron & 50364 & .013 & NA \\
\hline Bensulfuron-methyl & 61693 & .0158 & NA & Norflurazon & 49293 & .016 & NA \\
\hline Bentazon & 38711 & .011 & NA & Oryzalin & 49292 & .0176 & NA \\
\hline Bromacil & 04029 & .033 & NA & Oxamyl & 38866 & .0122 & NA \\
\hline Bromoxynil & 49311 & .017 & NA & Picloram & 49291 & .0198 & NA \\
\hline Caffeine & 50305 & .0096 & .0048 & Propham & 49236 & .0096 & NA \\
\hline Caffeine-C13 (surrogate) & 99959 & $.1 \mathrm{pct}$ & $.1 \mathrm{pct}$ & Propiconazole & 50471 & .021 & NA \\
\hline Carbaryl & 49310 & .0284 & .0142 & Propoxur & 38538 & .008 & NA \\
\hline Carbofuran & 49309 & .0056 & NA & Siduron & 38548 & .0168 & NA \\
\hline 3-Hydroxycarbofuran & 49308 & .0058 & NA & Sulfometuron-methyl & 50337 & .0088 & NA \\
\hline 3-Ketocarbofuran & 50295 & 1.5 & NA & Tebuthiuron & 82670 & .0062 & NA \\
\hline Chloramben, methyl ester & 61188 & .018 & NA & Terbacil & 04032 & .0098 & NA \\
\hline Chlorimuron-ethyl & 50306 & .0096 & NA & Triclopyr & 49235 & .0224 & NA \\
\hline Chlorothalonil & 49306 & .035 & .0173 & & & & \\
\hline Clopyralid & 49305 & .0138 & N/A & & & & \\
\hline Cycloate & 04031 & .013 & NA & & & & \\
\hline Dacthal monoacid & 49304 & .0116 & NA & & & & \\
\hline Dicamba & 38442 & .0128 & NA & & & & \\
\hline Dichlorprop & 49302 & .0138 & NA & & & & \\
\hline Dinoseb & 49301 & .012 & NA & & & & \\
\hline
\end{tabular}

${ }^{1}$ (2,4-dichlorophenoxy) acetic acid.

24-(2,4-dichlorophenoxy) butyric acid.

32-hydroxy-4-isopropylamino-6-ethylamino-s-triazine.

42-chloro-4-isopropylamino-6-amino-s-triazine.

${ }^{5}$ Chloro-di-amino-s-triazine.

${ }^{6}$ 2-chloro-6-ethylamino-4-amino-s-traizine.

72-methyl-4-chlorophenoxyacetic acid.

${ }^{8} 4$-(2-methyl-4-chlorophenoxy) butyric acid. 
Table 2-6. Pesticides analyzed at the Pennsylvania Department of Environmental Protection Laboratory (PADEPL) in Harrisburg, Pennsylvania, from August 2003 to December 2004.

[NWIS, National Water Information System; USEPA, U.S. Environmental Protection Agency; MDL, method detection limit; MRL, minimum reporting level; $\mu \mathrm{g} / \mathrm{L}$, micrograms per liter; RPA, Rhone Poulenc Agro; NA, not available; NC, no code; FY04, fiscal year 2004]

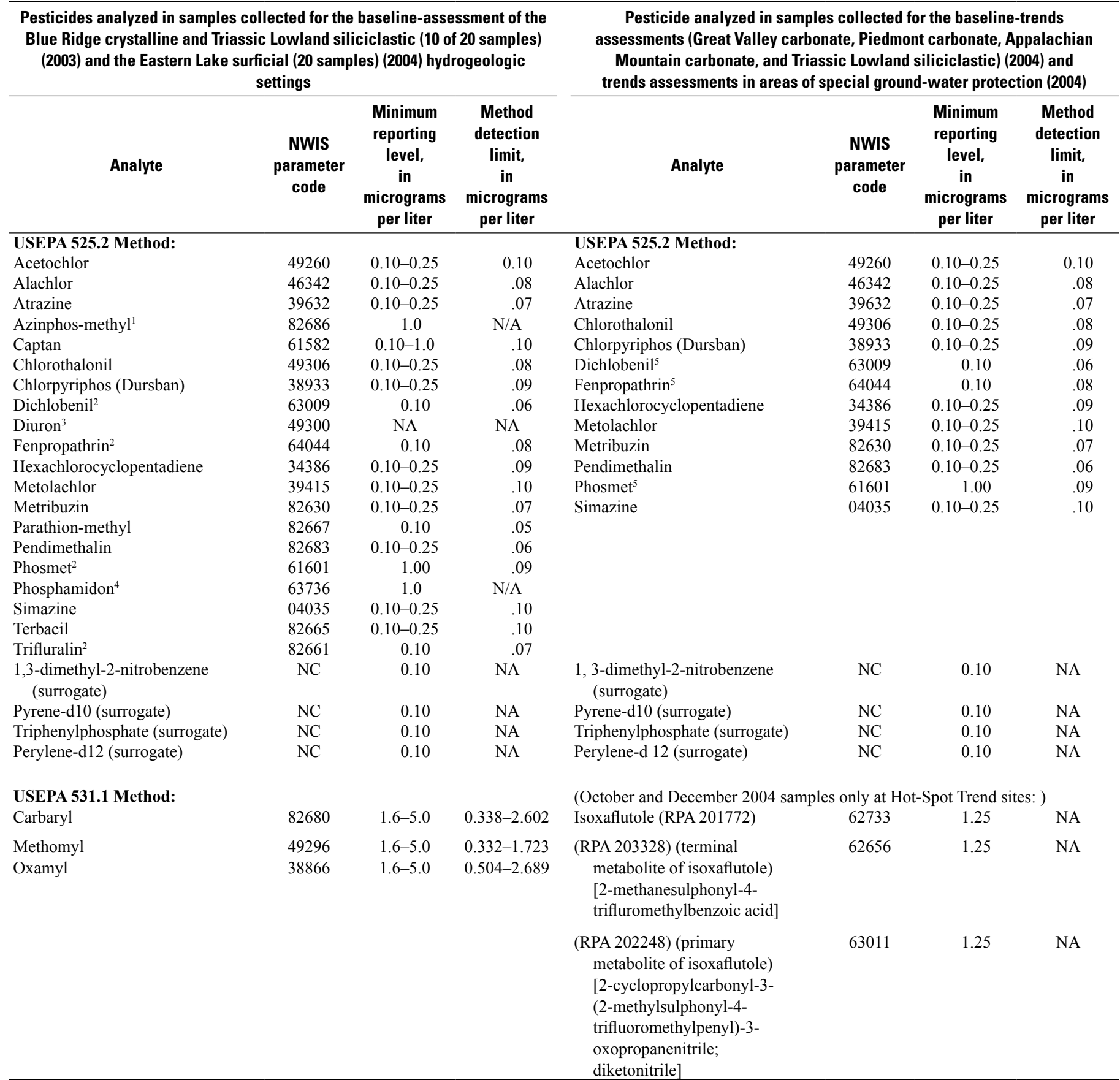

${ }^{1}$ MRLs during project were reported as $0.10-0.50 \mu \mathrm{g} / \mathrm{L}$. A PADEPL data review conducted in 2007 changed this level to $1.0 \mu \mathrm{g} / \mathrm{L}$.

${ }^{2} \mathrm{FY} 04$ addition.

${ }^{3}$ MRL during project was reported as $0.10 \mu \mathrm{g} / \mathrm{L}$. A PADEPL data review conducted in 2007 could not verify acceptable recoveries and mass spectra during the period of sample submittal; therefore, acceptable MDLs and MRLs are not possible.

${ }^{4} \mathrm{MRLs}$ during project were reported as $0.10-0.25 \mu \mathrm{g} / \mathrm{L}$. A PADEPL data review conducted in 2007 changed this level to $1.0 \mu \mathrm{g} / \mathrm{L}$.

${ }^{5}$ FY04 addition (July 2004) at the three hot-spot wells in the areas of special ground-water protection. 
quality-controlled spike solutions with nitrate concentrations ranging from 3.81 to $8.68 \mathrm{mg} / \mathrm{L}$ and nitrite concentrations ranging from 0.75 to $1.83 \mathrm{mg} / \mathrm{L}$. All nitrate and nitrite spikes were prepared using a pipet to transfer $10 \mathrm{~mL}$ of qualitycontrol concentrate into a $1-\mathrm{L}$ volumetric flask and diluting to volume with inorganic-blank water.

Six SRWS (N78, N82, N86, N90, N91, and N92) were submitted to the PADEPL to determine bias in recovery of nitrate and nitrite. SRWS are samples of known concentration prepared by the USGS Branch of Quality Systems in Denver, Colo. Recoveries of nitrate and nitrite reported for the SRWS were combined with recoveries calculated from triplicate FSRW samples to determine median recoveries.

To evaluate variability in nitrate and nitrite concentrations, RSDs were calculated from five triplicate field-spike sets and additional results from 11 well-water triplicate-set results (replicates). A median RSD from all triplicate-set results for nitrate and nitrite was then calculated.

\section{Bacteria}

For total coliform and E. coli bacteria, both the PADEPL and the OWML employ all method-required internal qualitycontrol samples to quality assure reported results. Both labs used the Colilert tray methodology; detail on internal qualitycontrol samples is found in SM 9223 (Enzyme Substrate Test) (American Public Health Association, American Water Works Association, and Water Pollution Control Federation, 2004).

No total coliform or E. coli samples were submitted as spiked samples for analysis of bias. Eighteen sets of wellwater triplicate sets were submitted for analysis of variability in bacteria results. There were no replicate sets for E. coli analyses where both samples had counts of bacteria, so estimates of variability could not be determined; however, 9 out of 18 sets of replicates for total coliform bacteria provided results for estimates of variability

\section{References Cited}

American Public Health Association, American Water Works Association, and Water Pollution Control Federation, 2004, Standard methods for the analysis of water and wastewater (21st ed.): Washington, D.C., American Public Health Association, Section 9223.

Fishman, M.J., ed., 1993, Methods of analysis by the U.S. Geological Survey National Water Quality LaboratoryDetermination of inorganic and organic constituents in water and fluvial sediments: U.S. Geological Survey Open-File Report 93-125, 217 p.

Friedman, L.C., and Erdmann, D.E., 1982, Quality assurance practices for the chemical and biological analyses of water and fluvial sediments: U.S. Geological Survey Techniques of Water-Resources Investigations, book 5, chap. A6, 181 p.

Furlong, E.T., Anderson, B.D., Werner, S.L., Soliven, P.P., Coffey, L.J., and Burkhardt, M.R., 2001, Methods of analysis by the U.S. Geological Survey National Water Quality Laboratory-Determination of pesticides in water by graphitized carbon-based solid-phase extraction and high-performance liquid chromatography/mass spectrometry: U.S. Geological Survey Water-Resources Investigations Report 01-4134, 73 p.

Hoaglin, D.C., Mosteller, F., and Tukey, J.S., 1983, Understanding robust and exploratory data analysis: New York, John Wiley and Sons, $447 \mathrm{p}$.

Lee, E.A., and Strahan, A.P., 2003, Methods of analysis by the U.S. Geological Survey Organic Geochemistry Research Group-Determination of acetamide herbicides and their degradation productions in water using online solid-phase extraction and high-performance liquid chromatography/ mass spectrometry: U.S. Geological Survey Open-File Report 03-173, $17 \mathrm{p}$. 
Lee, E.A., Strahan, A.P., and Thurman, E.M., 2002, Methods of analysis by the U.S. Geological Survey Organic Geochemistry Research Group-Determination of triazine and phenylurea herbicides and their degradation products in water using solid-phase extraction and liquid chromatography/mass spectrometry: U.S. Geological Survey OpenFile Report 02-436, 19 p.

Lindsey, B.D., and Bickford, T.M., 1999, Hydrogeologic framework and sampling design for an assessment of agricultural pesticides in ground water in Pennsylvania: U.S. Geological Survey Water-Resources Investigations Report 99-4076, $44 \mathrm{p}$.

Madsen, J.E., Sandstrom, M.W., and Zaugg, S.D., 2003, Methods of analysis by the U.S. Geological Survey National Water Quality Laboratory-A method supplement for the determination of fipronil and degradates in water by gas chromatography/mass spectrometry: U.S. Geological Survey Open-File Report 02-462, 11 p.

Pennsylvania Department of Agriculture, 1998, Pesticides and ground water strategy, January 2, 1998: Harrisburg, Pa., $36 \mathrm{p}$.

U.S. Geological Survey, variously dated, National field manual for the collection of water quality data: U.S. Geological Survey Techniques of Water-Resources Investigations, book 9, chaps. A1-A9, available online at http://pubs.water.usgs.gov/twri9A

U.S. Geological Survey, 1996, National Water Quality Laboratory, Calculation of matrix spike recovery: accessed June 16, 2008, at http://wwwnwql.cr.usgs.gov/USGS/SpikeCalc.html

Zaugg, S.D., Sandstrom, M.W., Smith, S.G., and Fehlberg, K.M., 1995, Methods of analysis by the U.S. Geological Survey National Water Quality Laboratory-Determination of pesticides in water by $\mathrm{C}-18$ solid-phase extraction and capillary-column gas chromatography/mass spectrometry with selected-ion monitoring: U.S. Geological Survey Open-File Report 95-181, 60 p. 
112 Pesticides in Ground Water in Selected Agricultural Land-Use Areas and Hydrogeologic Settings, Pennsylvania 
Table 2-2. Estimates of bias and variability in reported concentrations of nitrate, nitrite, total coliform and Escherichia coli (E. coli) bacteria, and pesticides using results from field-submitted and laboratory quality-control samples.

[Samples were analyzed at the Pennsylvania Department of Environmental Protection Laboratory, the U.S. Geological Survey National Water-Quality Laboratory, and the U.S. Geologidal Survey Ohio Water Microbiology Laboratory. $\mathrm{B}_{\mathrm{N}}$, number of blanks (equipment, trip, and field combined); $\mathrm{B}_{\mathrm{ND}}$, number of blanks in which compound was detected; $\mathrm{S}_{\mathrm{N}}$, number of samples; $\mathrm{R}_{\mathrm{N}}$, number of replicate sets; $\mathrm{R}_{\mathrm{SETDECT}}$, number of replicate sets within which compound was consistently detected; LRS, lab reagent spikes; SRWS, U.S. Geological Survey Standard Reference Water Sample; FSRW samples, field-spiked reagent water samples; ND, no detections NC, could not be calculated; env. reps, environmental replicates; CNBD, could not be determined; mg/L, miligrams per liter; $\mu \mathrm{g} / \mathrm{L}$, micrograms per liter; E, estimated; -, no data; GCMS, gas chromatography/mass spectrometry; HPLCMS, high-performance liquid chromatography/mass spectrometry; QC, quality control; NWIS, National Water Information System. Bolded compounds are currently reported as permanently estimated concentrations at the USGS NWQL due to poor recovery, bias, and (or) high variability in laboratory reagent water spikes; these compounds are reviewed annually, and if performance improves or degrades, the list of permanently estimated compounds may change; USGS(1), U.S. Geolgical Survey (USGS) National Water Quality Laboratory (NWQL) in Denver, Colo.; USGS(1), bias and variability evaluated using results from field-spiked reagent water samples; USGS(1), bias and variability evaluated using results from lab-reagent spikes; USGS(2), USGS Ohio Water Microbiology Laboratory in Columbus, Ohio [bacteria]; PADEPL, Pennsylvania Department of Environmental Protection Laboratory in Harrisburg, Pa.; PADEPL, bias and variability evaluated using results from field-spiked reagent water samples; PADEPL, bias and variability evaluated using results from lab-reagent spikes; NAV, not able to verify acceptable recovery; bolded black numbers indicate percents of bias or variability that did not meet project quality-assurance objectives] 
Table 2-2. Estimates of bias and variability in reported concentrations of nitrate, nitrite, total coliform and Escherichia coli (E. coli) bacteria, and pesticides using results from field-submitted and laboratory quality-control samples. - Continued

\begin{tabular}{|c|c|c|c|c|c|c|c|}
\hline \multirow{6}{*}{ Compound } & \multirow{6}{*}{$\begin{array}{l}\text { Lab } \\
\text { used }\end{array}$} & \multicolumn{6}{|c|}{ Evaluation of bias } \\
\hline & & \multicolumn{6}{|c|}{ Data sets used } \\
\hline & & \multicolumn{5}{|c|}{ Field-submitted samples } & \multirow[b]{2}{*}{$\begin{array}{l}\text { LRS samples } \\
\text { (Numbers of } \\
\text { spikes, } \\
\text { period of record, } \\
\text { and spike } \\
\text { concentrations } \\
\text { found in } \\
\text { footnote 2) }\end{array}$} \\
\hline & & \multicolumn{3}{|c|}{ Blank samples } & \multicolumn{2}{|c|}{$\begin{array}{c}\text { SRWS and triplicate FSRW } \\
\text { samples (nitrate and nitrite); } \\
\text { triplicate FSRW samples } \\
\text { (pesticides) } \\
\text { (Spike concentrations and } \\
\text { SRWS identifiers found in } \\
\text { footnote 1) }\end{array}$} & \\
\hline & & \multicolumn{3}{|c|}{$\begin{array}{l}\text { Bias, using concentration } \\
\text { (detections result in false } \\
\text { positives due to contamination) }\end{array}$} & \multicolumn{2}{|c|}{$\begin{array}{c}\text { Bias, } \\
\text { using recoveries, } \\
\text { in percent }\end{array}$} & $\begin{array}{c}\text { Bias, } \\
\text { using recoveries, } \\
\text { in percent }\end{array}$ \\
\hline & & $\mathrm{B}_{\mathrm{N}}$ & $\mathrm{B}_{\mathrm{ND}}$ & $\begin{array}{c}\text { Maximum } \\
\text { reported } \\
\text { concentration in } \\
\text { blanks }\end{array}$ & $\mathrm{S}_{\mathrm{N}}$ & $\begin{array}{l}\text { Median } \\
\text { recovery, } \\
\text { in percent }\end{array}$ & $\begin{array}{l}\text { Median recovery, } \\
\text { in percent }\end{array}$ \\
\hline \multirow[t]{2}{*}{ Nitrate $^{1}$} & PADEPL & 12 & 3 & $0.2 \mathrm{mg} / \mathrm{L}$ & 18 & 98 & - \\
\hline & USGS(1) & 3 & 0 & ND & 3 & 99 & - \\
\hline \multirow[t]{2}{*}{ Nitrite $^{1}$} & PADEPL & 12 & 0 & ND & 18 & 100 & - \\
\hline & USGS(1) & 3 & 0 & ND & 3 & 100 & - \\
\hline \multirow[t]{2}{*}{ Total coliform } & PADEPL & 7 & 0 & ND & 4 & $\mathrm{NC}$ & - \\
\hline & USGS(2) & 6 & 0 & ND & 4 & $\mathrm{NC}$ & - \\
\hline \multirow[t]{2}{*}{ E. coli } & PADEPL & 7 & 0 & ND & 4 & $\mathrm{NC}$ & - \\
\hline & USGS(2) & 6 & 0 & ND & 4 & $\mathrm{NC}$ & - \\
\hline \multirow[t]{2}{*}{ Acetochlor } & PADEPL & 3 & 0 & - & 12 & 84 & 98 \\
\hline & USGS(1) & 10 & 0 & - & 33 & 117 & 106 \\
\hline Acifluorfen & USGS(1) & 1 & 0 & - & 0 & - & 92 \\
\hline \multirow[t]{2}{*}{ Alachlor } & PADEPL & 3 & 0 & - & 12 & 95 & 102 \\
\hline & USGS(1) & 10 & 0 & - & 33 & 119 & 105 \\
\hline Aldicarb & USGS(1) & 1 & 0 & - & 3 & 11 & 9 \\
\hline Aldicarb sulfone & USGS(1) & 1 & 0 & - & 3 & 63 & 58 \\
\hline Aldicarb sulfoxide & USGS(1) & 1 & 0 & - & 3 & 25 & 42 \\
\hline $2,4-\mathrm{D}$ & USGS(1) & 1 & 0 & - & 0 & - & 114 \\
\hline 2,4-D methyl ester & USGS(1) & 1 & 0 & - & 0 & - & 76 \\
\hline 2,4-DB & USGS(1) & 1 & 0 & - & 0 & - & 72 \\
\hline $\begin{array}{l}\text { 2-chloro-6-ethylamino-4-amino-s-triazine (CEAT, } \\
\text { deisopropylatrazine) }\end{array}$ & USGS(1) & 1 & 0 & - & 0 & - & 62 \\
\hline 2-hydroxyatrazine & USGS(1) & 1 & 0 & - & 0 & - & 102 \\
\hline 3-(4-chlorophenyl)-1-methyl urea & USGS(1) & 1 & 0 & - & 0 & - & 95 \\
\hline Alpha -HCH & USGS(1) & 10 & 0 & - & 33 & 96 & 98 \\
\hline Alpha-HCH-d6 (surrogate) & USGS(1) & 10 & - & - & 33 & 93 & 94 \\
\hline \multirow{2}{*}{ Atrazine } & PADEPL & 3 & 0 & - & 12 & 85 & 94 \\
\hline & USGS(1) & 11 & 0 & - & 33 & 112 & $106(79)$ \\
\hline $\begin{array}{l}\text { 2-chloro-4-isopropylamino-6-amino-s-triazine (deethylatrazine; } \\
\text { CIAT) (permanent 'E' only for GCMS method) }\end{array}$ & USGS(1) & 11 & 0 & - & 33 & 26 & $44(72)$ \\
\hline \multirow[t]{2}{*}{ Azinphos-methyl } & PADEPL & 2 & 0 & - & 9 & 122 & 121 \\
\hline & USGS(1) & 10 & 0 & - & 33 & 90 & 87 \\
\hline Barban (positive ion surrogate) & USGS(1) & 1 & - & - & 3 & 86 & 96 \\
\hline Bendiocarb & USGS(1) & 1 & 0 & - & 0 & - & 71 \\
\hline Benfluralin & USGS(1) & 10 & 0 & - & 33 & 78 & 72 \\
\hline Benomyl & USGS(1) & 1 & 0 & - & 0 & - & 90 \\
\hline Bensulfuron-methyl & USGS(1) & 1 & 0 & - & 0 & - & 136 \\
\hline Bentazon & USGS(1) & 1 & 0 & - & 0 & - & 57 \\
\hline Bromacil & USGS(1) & 1 & 0 & - & 0 & - & 85 \\
\hline Bromoxynil & USGS(1) & 1 & 0 & - & 0 & - & 58 \\
\hline Butylate & USGS(1) & 10 & 0 & - & 33 & 96 & 93 \\
\hline $2,4,5-T$ (negative ion surrogate) & USGS(1) & 1 & - & - & 3 & 66 & 83 \\
\hline Caffeine & USGS(1) & 1 & 0 & - & 0 & - & 96 \\
\hline Caffeine-13C (positive ion surrogate) & USGS(1) & 1 & - & - & 3 & 102 & 98 \\
\hline
\end{tabular}


Table 2-2. Estimates of bias and variability in reported concentrations of nitrate, nitrite, total coliform and Escherichia coli (E. coli) bacteria, and pesticides using results from field-submitted and laboratory quality-control samples. - Continued

\begin{tabular}{|c|c|c|c|c|c|c|}
\hline \multirow{6}{*}{ Compound } & \multirow{6}{*}{$\begin{array}{l}\text { Lab } \\
\text { used }\end{array}$} & \multicolumn{5}{|c|}{ Evaluation of variability } \\
\hline & & \multicolumn{5}{|c|}{ Data sets used } \\
\hline & & \multicolumn{4}{|c|}{ Field-submitted samples } & \multirow[b]{2}{*}{$\begin{array}{l}\text { LRS samples } \\
\text { (Numbers of } \\
\text { spikes, } \\
\text { period of record, } \\
\text { and spike } \\
\text { concentrations } \\
\text { found in } \\
\text { footnote 2) }\end{array}$} \\
\hline & & $\begin{array}{c}\text { SRWS and triplicate } \\
\text { FSRW samples } \\
\text { (nitrate and nitrite); } \\
\text { triplicate FSRW samples } \\
\text { (pesticides) }\end{array}$ & tripl & $\begin{array}{l}\text { icate env } \\
\text { triplicate } \\
\text { trate and } \\
\text { plicate e } \\
\text { I coliform } \\
\text { SRW sam }\end{array}$ & $\begin{array}{l}\text { ps. and } \\
\text { RW } \\
\text { rite); } \\
\text { reps } \\
\text { cteria); } \\
\text { s (pesticides) }\end{array}$ & \\
\hline & & $\begin{array}{l}\text { Variabiliy, using } \\
\text { F-pseudosigma of } \\
\text { recoveries, } \\
\text { in percent. }\end{array}$ & \multicolumn{3}{|c|}{$\begin{array}{c}\text { Variability, using median relative } \\
\text { standard deviation (RSD) of concentrations } \\
\text { in triplicate sets }\end{array}$} & $\begin{array}{c}\text { Variabiliy, } \\
\text { using } \\
\text { F-pseudosigma of } \\
\text { recoveries, } \\
\text { in percent. }\end{array}$ \\
\hline & & $\begin{array}{l}\text { F-pseudo-sigma, } \\
\text { in percent }\end{array}$ & $\mathbf{R}_{\mathrm{N}}$ & $\mathbf{R}_{\text {SETDECT }}$ & $\begin{array}{l}\text { Median RSD, in } \\
\text { percent }\end{array}$ & $\begin{array}{l}\text { F-pseudosigma, } \\
\text { in percent }\end{array}$ \\
\hline \multirow[t]{2}{*}{ Nitrate } & PADEPL & 5 & 14 & 10 & 2 & - \\
\hline & USGS(1) & 2 & 2 & 2 & 2 & - \\
\hline \multirow[t]{2}{*}{ Nitrite } & PADEPL & 4 & 14 & 6 & 0 & - \\
\hline & USGS(1) & 1 & 2 & 1 & 1 & - \\
\hline \multirow[t]{2}{*}{ Total coliform } & PADEPL & $\mathrm{NC}$ & 17 & 9 & 25 & - \\
\hline & USGS(2) & $\mathrm{NC}$ & 1 & 0 & $\mathrm{NC}$ & - \\
\hline \multirow[t]{2}{*}{ E. coli } & PADEPL & $\mathrm{NC}$ & 17 & 0 & $\mathrm{NC}$ & - \\
\hline & USGS(2) & $\mathrm{NC}$ & 1 & 0 & $\mathrm{NC}$ & - \\
\hline \multirow[t]{2}{*}{ Acetochlor } & PADEPL & 20 & 4 & 4 & 10 & 22 \\
\hline & USGS(1) & 11 & 11 & 11 & 2 & 15 \\
\hline Acifluorfen & USGS(1) & - & 0 & - & - & 15 \\
\hline \multirow[t]{2}{*}{ Alachlor } & PADEPL & 18 & 4 & 4 & 8 & 27 \\
\hline & USGS(1) & 7 & 11 & 11 & 2 & 14 \\
\hline Aldicarb & USGS(1) & 13 & 1 & 1 & 89 & 33 \\
\hline Aldicarb sulfone & USGS(1) & 7 & 1 & 1 & 17 & 24 \\
\hline Aldicarb sulfoxide & USGS(1) & 5 & 1 & 1 & 26 & 16 \\
\hline $2,4-\mathrm{D}$ & USGS(1) & - & 0 & - & - & 17 \\
\hline 2,4-D methyl ester & USGS(1) & - & 0 & - & - & 13 \\
\hline 2,4-DB & USGS(1) & - & 0 & - & - & 11 \\
\hline $\begin{array}{l}\text { 2-chloro-6-ethylamino-4-amino-s-triazine (CEAT, } \\
\text { deisopropylatrazine) }\end{array}$ & USGS(1) & - & 0 & - & - & 14 \\
\hline 2-hydroxyatrazine & USGS(1) & - & 0 & - & - & 20 \\
\hline 3-(4-chlorophenyl)-1-methyl urea & USGS(1) & - & 0 & - & - & 12 \\
\hline Alpha-HCH & USGS(1) & 12 & 11 & 11 & 2 & 10 \\
\hline Alpha-HCH-d6 (surrogate) & USGS(1) & 10 & 11 & 11 & 3 & 8 \\
\hline \multirow[t]{2}{*}{ Atrazine } & PADEPL & 6 & 4 & 4 & 12 & 25 \\
\hline & USGS(1) & 7 & 11 & 11 & 2 & $13(13)$ \\
\hline $\begin{array}{l}\text { 2-chloro-4-isopropylamino-6-amino-s-triazine (deethylatrazine; } \\
\text { CIAT) (permanent 'E' only for GCMS method) }\end{array}$ & USGS(1) & 6 & 11 & 11 & 2 & $17(19)$ \\
\hline \multirow[t]{2}{*}{ Azinphos-methyl } & PADEPL & 78 & 3 & 3 & 7 & 54 \\
\hline & USGS(1) & 41 & 11 & 11 & 4 & 35 \\
\hline Barban (positive ion surrogate) & USGS(1) & 13 & 1 & 1 & 19 & 14 \\
\hline Bendiocarb & USGS(1) & - & 0 & - & - & 12 \\
\hline Benfluralin & USGS(1) & 8 & 11 & 11 & 4 & 12 \\
\hline Benomyl & USGS(1) & - & 0 & - & - & 24 \\
\hline Bensulfuron-methyl & USGS(1) & - & 0 & - & - & 35 \\
\hline Bentazon & USGS(1) & - & 0 & - & - & 48 \\
\hline Bromacil & USGS(1) & - & 0 & - & - & 35 \\
\hline Bromoxynil & USGS(1) & - & 0 & - & - & 44 \\
\hline Butylate & USGS(1) & 8 & 11 & 11 & 1 & 10 \\
\hline 2,4,5-T (negative ion surrogate) & USGS(1) & 3 & 1 & 1 & 7 & 14 \\
\hline Caffeine & USGS(1) & - & 0 & - & - & 12 \\
\hline Caffeine-13C (positive ion surrogate) & USGS(1) & 7 & 1 & 1 & 10 & 16 \\
\hline
\end{tabular}


Table 2-2. Estimates of bias and variability in reported concentrations of nitrate, nitrite, total coliform and Escherichia coli (E. coli) bacteria, and pesticides using results from field-submitted and laboratory quality-control samples. - Continued

\begin{tabular}{|c|c|c|c|c|c|c|c|}
\hline \multirow{6}{*}{ Compound } & \multirow{6}{*}{$\begin{array}{l}\text { Lab } \\
\text { used }\end{array}$} & \multicolumn{6}{|c|}{ Evaluation of bias } \\
\hline & & \multicolumn{6}{|c|}{ Data sets used } \\
\hline & & \multicolumn{5}{|c|}{ Field-submitted samples } & \multirow{3}{*}{ 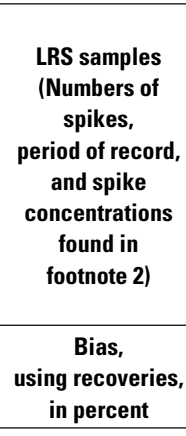 } \\
\hline & & & lank s & & $\begin{array}{r}\text { SRWS } \\
\text { samples } \\
\text { triplic } \\
\\
\text { (Spike } \\
\text { SRWS }\end{array}$ & $\begin{array}{l}\text { icate FSRW } \\
\text { and nitrite); } \\
\text { W samples } \\
\text { des) } \\
\text { trations and } \\
\text { rs found in } \\
\text { e 1) }\end{array}$ & \\
\hline & & \multicolumn{3}{|c|}{$\begin{array}{l}\text { Bias, using concentration } \\
\text { (detections result in false } \\
\text { positives due to contamination) }\end{array}$} & \multicolumn{2}{|c|}{$\begin{array}{c}\text { Bias, } \\
\text { using recoveries, } \\
\text { in percent }\end{array}$} & \\
\hline & & $\mathbf{B}_{\mathrm{N}}$ & $\mathbf{B}_{\mathrm{ND}}$ & $\begin{array}{c}\text { Maximum } \\
\text { reported } \\
\text { concentration in } \\
\text { blanks }\end{array}$ & $\mathrm{S}_{\mathrm{N}}$ & $\begin{array}{l}\text { Median } \\
\text { recovery, } \\
\text { in percent }\end{array}$ & $\begin{array}{l}\text { Median recovery, } \\
\text { in percent }\end{array}$ \\
\hline Captan & PADEPL & 2 & 0 & - & 6 & $\mathbf{0}$ & 95 \\
\hline \multirow[t]{2}{*}{ Carbaryl } & PADEPL & 2 & 0 & - & 9 & 87 & 103 \\
\hline & USGS(1) & 11 & 0 & - & 33 & 108 & $111(87)$ \\
\hline Carbofuran & USGS(1) & 11 & 0 & - & 33 & 96 & $113(86)$ \\
\hline 3-Hydroxy carbofuran & USGS(1) & 3 & 0 & - & 3 & 78 & 85 \\
\hline 3-keto-carbofuran & USGS(1) & 1 & 0 & - & 0 & - & 32 \\
\hline Chloramben methyl ester & USGS(1) & 1 & 0 & - & 0 & - & 64 \\
\hline $\begin{array}{l}\text { Chlordiamino-s-triazine (CAAT, desethyl desisopropyl atra- } \\
\text { zine) }\end{array}$ & USGS(1) & 1 & 0 & - & 0 & - & 47 \\
\hline Chlorimuron-ethyl & USGS(1) & 1 & 0 & - & 0 & - & 205 \\
\hline \multirow[t]{2}{*}{ Chlorothalonil } & USGS(1) & 1 & 0 & - & 0 & - & 7 \\
\hline & PADEPL & 3 & 0 & - & 9 & 75 & 97 \\
\hline Clopyralid & USGS(1) & 1 & 0 & - & 0 & - & 69 \\
\hline \multirow[t]{2}{*}{ Chlorpyrifos (Dursban) } & PADEPL & 3 & 0 & - & 12 & 82 & 95 \\
\hline & USGS(1) & 10 & 0 & - & 33 & 99 & 98 \\
\hline cis-Permethrin & USGS(1) & 10 & 0 & - & 33 & 54 & 42 \\
\hline Cyanazine & USGS(1) & 10 & 0 & - & 33 & 100 & 108 \\
\hline \begin{tabular}{|l|} 
Cycloate \\
\end{tabular} & USGS(1) & 1 & 0 & - & 0 & - & 42 \\
\hline Dacthal (DCPA) & USGS(1) & 10 & 0 & - & 33 & 111 & 106 \\
\hline Dacthal monoacid & USGS(1) & 1 & 0 & - & 0 & - & 94 \\
\hline Desulfinylfipronil & USGS(1) & 10 & 0 & - & 27 & 118 & 112 \\
\hline Desulfinylfipronil amide & USGS(1) & 10 & 0 & - & 27 & 64 & 112 \\
\hline Diazanon & USGS(1) & 10 & 0 & - & 33 & 102 & 103 \\
\hline Diazinon-d10(surrogate) & USGS(1) & 10 & - & - & 33 & 111 & 103 \\
\hline Dicambia & USGS(1) & 1 & 0 & - & 0 & - & 97 \\
\hline Dichlobenil & PADEPL & 2 & 0 & - & 0 & - & 100 \\
\hline Dichlorprop & USGS(1) & 1 & 0 & - & 0 & - & 89 \\
\hline Dieldrin & USGS(1) & 10 & 0 & - & 33 & 93 & 94 \\
\hline 2,6-Diethylaniline ${ }^{4}$ & USGS(1) & 10 & 0 & - & 33 & (33) & 94 \\
\hline 1,3-dimethyl-2-nitrobenzene (surrogate) & PADEPL & 3 & - & - & 12 & 93 & 93 \\
\hline Dinoseb & USGS(1) & 1 & 0 & - & 0 & - & 73 \\
\hline Diphenamid & USGS(1) & 1 & 0 & - & 0 & - & 84 \\
\hline Disulfoton & USGS(1) & 10 & 0 & - & 33 & 50 & 43 \\
\hline \multirow[t]{2}{*}{ Diuron } & USGS(1) & 1 & 0 & - & 0 & - & 92 \\
\hline & PADEPL & 2 & 0 & - & 6 & 101 & NAV \\
\hline EPTC & USGS(1) & 10 & 0 & - & 33 & 94 & 93 \\
\hline Ethalfluralin & USGS(1) & 10 & 0 & - & 33 & 73 & 87 \\
\hline Ethoprop & USGS(1) & 10 & 0 & - & 33 & 94 & 90 \\
\hline Fenpropathrin & PADEPL & 2 & 0 & - & 0 & - & 87 \\
\hline Fenuron & USGS(1) & 1 & 0 & 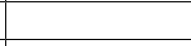 & 0 & - & 86 \\
\hline Fipronil & USGS(1) & 10 & 0 & - & 27 & 106 & 119 \\
\hline Fipronil sulfide & USGS(1) & 10 & 0 & - & 27 & 109 & 103 \\
\hline Fipronil sulfone & USGS(1) & 10 & 0 & - & 27 & 84 & 89 \\
\hline
\end{tabular}


Table 2-2. Estimates of bias and variability in reported concentrations of nitrate, nitrite, total coliform and Escherichia coli (E. coli) bacteria, and pesticides using results from field-submitted and laboratory quality-control samples.-Continued

\begin{tabular}{|c|c|c|c|c|c|c|}
\hline \multirow{6}{*}{ Compound } & \multirow{6}{*}{$\begin{array}{l}\text { Lab } \\
\text { used }\end{array}$} & \multicolumn{5}{|c|}{ Evaluation of variability } \\
\hline & & \multicolumn{5}{|c|}{ Data sets used } \\
\hline & & \multicolumn{4}{|c|}{ Field-submitted samples } & \multirow[b]{2}{*}{$\begin{array}{l}\text { LRS samples } \\
\text { (Numbers of } \\
\text { spikes, } \\
\text { period of record, } \\
\text { and spike } \\
\text { concentrations } \\
\text { found in } \\
\text { footnote 2) } \\
\end{array}$} \\
\hline & & \begin{tabular}{|c} 
SRWS and triplicate \\
FSRW samples \\
(nitrate and nitrite); \\
triplicate FSRW samples \\
(pesticides)
\end{tabular} & tripl & $\begin{array}{l}\text { icate env } \\
\text { riplicate } \\
\text { trate and } \\
\text { plicate e } \\
\text { coliform } \\
\text { SRW sam }\end{array}$ & $\begin{array}{l}\text { ps. and } \\
\text { RW } \\
\text { rite); } \\
\text { reps } \\
\text { cteria); } \\
\text { s (pesticides) }\end{array}$ & \\
\hline & & $\begin{array}{l}\text { Variabiliy, using } \\
\text { F-pseudosigma of } \\
\text { recoveries, } \\
\text { in percent. }\end{array}$ & \multicolumn{3}{|c|}{$\begin{array}{c}\text { Variability, using median relative } \\
\text { standard deviation (RSD) of concentrations } \\
\text { in triplicate sets }{ }^{3}\end{array}$} & $\begin{array}{l}\text { Variabiliy, } \\
\text { using } \\
\text { F-pseudosigma of } \\
\text { recoveries, } \\
\text { in percent. }\end{array}$ \\
\hline & & $\begin{array}{l}\text { F-pseudo-sigma, } \\
\text { in percent }\end{array}$ & $\mathbf{R}_{\mathrm{N}}$ & $\mathbf{R}_{\text {SETDECT }}$ & $\begin{array}{l}\text { Median RSD, in } \\
\text { percent }\end{array}$ & $\begin{array}{l}\text { F-pseudosigma, } \\
\text { in percent }\end{array}$ \\
\hline Captan & PADEPL & $\mathrm{NC}$ & 2 & 0 & $\mathrm{NC}$ & 37 \\
\hline \multirow[t]{2}{*}{ Carbaryl } & PADEPL & 8 & 3 & 3 & 6 & 12 \\
\hline & USGS(1) & 44 & 11 & 11 & 6 & $35(11)$ \\
\hline Carbofuran & USGS(1) & 17 & 11 & 11 & 7 & $27(12)$ \\
\hline 3-Hydroxy carbofuran & USGS(1) & 9 & 1 & 1 & 15 & 30 \\
\hline 3-keto-carbofuran & USGS(1) & - & 0 & - & - & 12 \\
\hline Chloramben methyl ester & USGS(1) & - & 0 & - & - & 38 \\
\hline $\begin{array}{l}\text { Chlordiamino-s-triazine (CAAT, desethyl desisopropyl atra- } \\
\text { zine) }\end{array}$ & USGS(1) & - & 0 & - & - & 21 \\
\hline Chlorimuron-ethyl & USGS(1) & - & 0 & - & - & 46 \\
\hline \multirow[t]{2}{*}{ Chlorothalonil } & USGS(1) & - & 0 & - & - & 11 \\
\hline & PADEPL & 15 & 3 & 3 & 8 & 17 \\
\hline Clopyralid & USGS(1) & - & 0 & - & - & 21 \\
\hline \multirow[t]{2}{*}{ Chlorpyrifos (Dursban) } & PADEPL & 11 & 4 & 4 & 9 & 18 \\
\hline & USGS(1) & 13 & 11 & 11 & 4 & 11 \\
\hline cis-Permethrin & USGS(1) & 10 & 11 & 11 & 6 & 17 \\
\hline Cyanazine & USGS(1) & 18 & 11 & 11 & 3 & 20 \\
\hline Cycloate & USGS(1) & - & 0 & - & - & 45 \\
\hline Dacthal (DCPA) & USGS(1) & 13 & 11 & 11 & 1 & 10 \\
\hline Dacthal monoacid & USGS(1) & - & 0 & - & - & 15 \\
\hline Desulfinylfipronil & USGS(1) & 17 & 9 & 9 & 3 & 17 \\
\hline Desulfinylfipronil amide & USGS(1) & 11 & 9 & 9 & 6 & 34 \\
\hline Diazanon & USGS(1) & 10 & 11 & 11 & 2 & 12 \\
\hline Diazinon-d10(surrogate) & USGS(1) & 9 & 11 & 11 & 2 & 12 \\
\hline Dicambia & USGS(1) & - & 0 & - & - & 11 \\
\hline Dichlobenil & PADEPL & - & 0 & - & - & 18 \\
\hline Dichlorprop & USGS(1) & - & 0 & - & - & 9 \\
\hline Dieldrin & USGS(1) & 22 & 11 & 11 & 3 & 13 \\
\hline 2,6-Diethylaniline ${ }^{4}$ & USGS(1) & (59) & 11 & 11 & 5 & 11 \\
\hline 1,3-dimethyl-2-nitrobenzene (surrogate) & PADEPL & 7 & 4 & 4 & 2 & 10 \\
\hline Dinoseb & USGS(1) & - & 0 & - & - & 20 \\
\hline Diphenamid & USGS(1) & - & 0 & - & - & 12 \\
\hline Disulfoton & USGS(1) & 14 & 11 & 11 & 4 & 38 \\
\hline \multirow[t]{2}{*}{ Diuron } & USGS(1) & - & 0 & - & - & 10 \\
\hline & PADEPL & 16 & 2 & 2 & 11 & NAV \\
\hline EPTC & USGS(1) & 9 & 11 & 11 & 2 & 8 \\
\hline Ethalfluralin & USGS(1) & 12 & 11 & 11 & 3 & 14 \\
\hline Ethoprop & USGS(1) & 14 & 11 & 11 & 2 & 13 \\
\hline Fenpropathrin & PADEPL & - & 0 & - & - & 36 \\
\hline Fenuron & USGS(1) & - & 0 & - & - & 21 \\
\hline Fipronil & USGS(1) & 27 & 9 & 9 & 5 & 31 \\
\hline Fipronil sulfide & USGS(1) & 13 & 9 & 9 & 5 & 17 \\
\hline Fipronil sulfone & USGS(1) & 11 & 9 & 9 & 4 & 20 \\
\hline
\end{tabular}


Table 2-2. Estimates of bias and variability in reported concentrations of nitrate, nitrite, total coliform and Escherichia coli (E. coli) bacteria, and pesticides using results from field-submitted and laboratory quality-control samples. - Continued

\begin{tabular}{|c|c|c|c|c|c|c|c|}
\hline \multirow{6}{*}{ Compound } & \multirow{6}{*}{$\begin{array}{l}\text { Lab } \\
\text { used }\end{array}$} & \multicolumn{6}{|c|}{ Evaluation of bias } \\
\hline & & \multicolumn{6}{|c|}{ Data sets used } \\
\hline & & \multicolumn{5}{|c|}{ Field-submitted samples } & \multirow[b]{2}{*}{$\begin{array}{l}\text { LRS samples } \\
\text { (Numbers of } \\
\text { spikes, } \\
\text { period of record, } \\
\text { and spike } \\
\text { concentrations } \\
\text { found in } \\
\text { footnote 2) }\end{array}$} \\
\hline & & \multicolumn{3}{|c|}{ Blank samples } & \multicolumn{2}{|c|}{$\begin{array}{l}\text { SRWS and triplicate FSRW } \\
\text { samples (nitrate and nitrite); } \\
\text { triplicate FSRW samples } \\
\text { (pesticides) } \\
\text { (Spike concentrations and } \\
\text { SRWS identifiers found in } \\
\text { footnote 1) }\end{array}$} & \\
\hline & & \multicolumn{3}{|c|}{$\begin{array}{l}\text { Bias, using concentration } \\
\text { (detections result in false } \\
\text { positives due to contamination) }\end{array}$} & \multicolumn{2}{|c|}{$\begin{array}{l}\text { Bias, } \\
\text { using recoveries, } \\
\text { in percent }\end{array}$} & \multirow{2}{*}{$\begin{array}{c}\text { Bias, } \\
\text { using recoveries, } \\
\text { in percent } \\
\begin{array}{c}\text { Median recovery, } \\
\text { in percent }\end{array}\end{array}$} \\
\hline & & $\mathbf{B}_{\mathrm{N}}$ & $\mathrm{B}_{\mathrm{ND}}$ & $\begin{array}{c}\text { Maximum } \\
\text { reported } \\
\text { concentration in } \\
\text { blanks }\end{array}$ & $\mathbf{S}_{\mathrm{N}}$ & $\begin{array}{l}\text { Median } \\
\text { recovery, } \\
\text { in percent }\end{array}$ & \\
\hline Fonofos & USGS(1) & 10 & 0 & - & 33 & 106 & 94 \\
\hline Flumetsulam & USGS(1) & 1 & 0 & - & 0 & - & 136 \\
\hline Fluometuron & USGS(1) & 1 & 0 & - & 0 & - & 87 \\
\hline Hexachlorocyclopentadiene & PADEPL & 3 & 0 & - & 9 & 30 & 87 \\
\hline Imazaquin & USGS(1) & 1 & 0 & - & 0 & - & 133 \\
\hline Imazethapyr & USGS(1) & 1 & 0 & - & 0 & - & 116 \\
\hline Imidacloprid & USGS(1) & 1 & 0 & - & 0 & - & 122 \\
\hline Lindane & USGS(1) & 10 & 0 & - & 33 & 100 & 102 \\
\hline Linuron & USGS(1) & 11 & 0 & - & 33 & 122 & $101(86)$ \\
\hline Malathion & USGS(1) & 10 & 0 & - & 33 & 108 & 104 \\
\hline Metalaxyl & USGS(1) & 1 & 0 & - & 0 & - & 81 \\
\hline Methiocarb & USGS(1) & 1 & 0 & - & 3 & 16 & 62 \\
\hline \multirow[t]{2}{*}{ Methomyl } & PADEPL & 2 & 0 & - & 9 & 98 & 100 \\
\hline & USGS(1) & 1 & 0 & - & 3 & 29 & 71 \\
\hline \multirow[t]{2}{*}{ Metolachlor } & PADEPL & 3 & 0 & - & 12 & 90 & 99 \\
\hline & USGS(1) & 10 & 0 & - & 33 & 119 & 104 \\
\hline \multirow[t]{2}{*}{ Metribuzin } & PADEPL & 3 & 0 & - & 12 & 72 & 78 \\
\hline & USGS(1) & 10 & 0 & - & 33 & 65 & 84 \\
\hline Metsulfuron-methyl & USGS(1) & 1 & 0 & - & 0 & - & 40 \\
\hline MCPA & USGS(1) & 1 & 0 & - & 0 & - & 84 \\
\hline $\mathrm{MCPB}$ & USGS(1) & 1 & 0 & - & 0 & - & 73 \\
\hline Molinate & USGS(1) & 10 & 0 & - & 33 & 100 & 95 \\
\hline Napropamide & USGS(1) & 10 & 0 & - & 33 & 108 & 94 \\
\hline Neburon & USGS(1) & 1 & 0 & - & 0 & - & 92 \\
\hline Nicosulfuron & USGS(1) & 1 & 0 & - & 0 & - & 184 \\
\hline Norflurazon & USGS(1) & 1 & 0 & - & 0 & - & 88 \\
\hline Oryzalin & USGS(1) & 1 & 0 & - & 0 & - & 77 \\
\hline \multirow[t]{2}{*}{ Oxamyl } & PADEPL & 2 & 0 & - & 9 & 94 & 107 \\
\hline & USGS(1) & 1 & 0 & - & 3 & 49 & 70 \\
\hline p,p'-DDE & USGS(1) & 10 & 1 & E 0.0009 & 33 & 60 & 61 \\
\hline Parathion & USGS(1) & 10 & 0 & - & 33 & 105 & 99 \\
\hline \multirow[t]{2}{*}{ Parathion-methyl } & PADEPL & 2 & 0 & - & 9 & 94 & 90 \\
\hline & USGS(1) & 10 & 0 & - & 33 & 95 & 93 \\
\hline Pebulate & USGS(1) & 10 & 0 & - & 33 & 98 & 94 \\
\hline \multirow[t]{2}{*}{ Pendimethalin } & PADEPL & 3 & 0 & - & 12 & 94 & 87 \\
\hline & USGS(1) & 10 & 0 & - & 33 & 90 & 79 \\
\hline Perylene-d12 (surrogate) & PADEPL & 3 & - & - & 12 & 103 & 98 \\
\hline Phorate & USGS(1) & 10 & 0 & - & 33 & 74 & 64 \\
\hline Phosphamidon & PADEPL & 2 & 0 & - & 6 & 121 & 99 \\
\hline Phosmet & PADEPL & 2 & 0 & - & 0 & - & 115 \\
\hline Picloram & USGS(1) & 1 & 0 & - & 0 & - & 88 \\
\hline Prometon & USGS(1) & 10 & 0 & - & 33 & 105 & 105 \\
\hline Propachlor & USGS(1) & 10 & 0 & - & 33 & 111 & 106 \\
\hline
\end{tabular}


Table 2-2. Estimates of bias and variability in reported concentrations of nitrate, nitrite, total coliform and Escherichia coli (E. coli) bacteria, and pesticides using results from field-submitted and laboratory quality-control samples.-Continued

\begin{tabular}{|c|c|c|c|c|c|c|}
\hline \multirow{6}{*}{ Compound } & \multirow{6}{*}{$\begin{array}{l}\text { Lab } \\
\text { used }\end{array}$} & \multicolumn{5}{|c|}{ Evaluation of variability } \\
\hline & & \multicolumn{5}{|c|}{ Data sets used } \\
\hline & & \multicolumn{4}{|c|}{ Field-submitted samples } & \multirow[b]{2}{*}{$\begin{array}{l}\text { LRS samples } \\
\text { (Numbers of } \\
\text { spikes, } \\
\text { period of record, } \\
\text { and spike } \\
\text { concentrations } \\
\text { found in } \\
\text { footnote 2) }\end{array}$} \\
\hline & & \begin{tabular}{|c|} 
SRWS and triplicate \\
FSRW samples \\
(nitrate and nitrite); \\
triplicate FSRW samples \\
(pesticides)
\end{tabular} & tripl & $\begin{array}{l}\text { icate env. } \\
\text { triplicate } \\
\text { trate and } \\
\text { plicate er } \\
\text { coliform } \\
\text { SRW sam }\end{array}$ & $\begin{array}{l}\text { ps. and } \\
\text { RW } \\
\text { rite); } \\
\text { reps } \\
\text { cteria); } \\
\text { s (pesticides) }\end{array}$ & \\
\hline & & $\begin{array}{l}\text { Variabiliy, using } \\
\text { F-pseudosigma of } \\
\text { recoveries, } \\
\text { in percent. }\end{array}$ & \multicolumn{3}{|c|}{$\begin{array}{c}\text { Variability, using median relative } \\
\text { standard deviation (RSD) of concentrations } \\
\text { in triplicate sets }\end{array}$} & $\begin{array}{c}\text { Variabiliy, } \\
\text { using } \\
\text { F-pseudosigma of } \\
\text { recoveries, } \\
\text { in percent. }\end{array}$ \\
\hline & & $\begin{array}{l}\text { F-pseudo-sigma, } \\
\text { in percent }\end{array}$ & $\mathbf{R}_{\mathrm{N}}$ & $\mathbf{R}_{\text {Setdect }}$ & $\begin{array}{l}\text { Median RSD, in } \\
\text { percent }\end{array}$ & $\begin{array}{l}\text { F-pseudosigma, } \\
\text { in percent }\end{array}$ \\
\hline Fonofos & USGS(1) & 11 & 11 & 11 & 2 & 14 \\
\hline Flumetsulam & USGS(1) & - & 0 & - & - & 28 \\
\hline Fluometuron & USGS(1) & - & 0 & - & - & 10 \\
\hline Hexachlorocyclopentadiene & PADEPL & 25 & 3 & 3 & 6 & 29 \\
\hline Imazaquin & USGS(1) & - & 0 & - & - & 27 \\
\hline Imazethapyr & USGS(1) & - & 0 & - & - & 28 \\
\hline Imidacloprid & USGS(1) & - & 0 & - & - & 24 \\
\hline Lindane & USGS(1) & 13 & 11 & 11 & 2 & 11 \\
\hline Linuron & USGS(1) & 24 & 11 & 11 & 4 & $31(8)$ \\
\hline Malathion & USGS(1) & 19 & 11 & 11 & 3 & 17 \\
\hline Metalaxyl & USGS(1) & - & 0 & - & - & 11 \\
\hline Methiocarb & USGS(1) & 21 & 1 & 1 & 93 & 60 \\
\hline \multirow[t]{2}{*}{ Methomyl } & PADEPL & 9 & 3 & 3 & 7 & 5 \\
\hline & USGS(1) & 14 & 1 & 1 & 52 & 50 \\
\hline \multirow[t]{2}{*}{ Metolachlor } & PADEPL & 20 & 4 & 4 & 6 & 15 \\
\hline & USGS(1) & 12 & 11 & 11 & 2 & 15 \\
\hline \multirow[t]{2}{*}{ Metribuzin } & PADEPL & 15 & 4 & 4 & 5 & 9 \\
\hline & USGS(1) & 9 & 11 & 11 & 3 & 16 \\
\hline Metsulfuron-methyl & USGS(1) & - & 0 & - & - & 35 \\
\hline MCPA & USGS(1) & - & 0 & - & - & 12 \\
\hline MCPB & USGS(1) & - & 0 & - & - & 12 \\
\hline Molinate & USGS(1) & 12 & 11 & 11 & 1 & 10 \\
\hline Napropamide & USGS(1) & 20 & 11 & 11 & 3 & 15 \\
\hline Neburon & USGS(1) & - & 0 & - & - & 12 \\
\hline Nicosulfuron & USGS(1) & - & 0 & - & - & 50 \\
\hline Norflurazon & USGS(1) & - & 0 & - & - & 32 \\
\hline Oryzalin & USGS(1) & - & 0 & - & - & 16 \\
\hline \multirow[t]{2}{*}{ Oxamyl } & PADEPL & 10 & 3 & 3 & 6 & 7 \\
\hline & USGS(1) & 5 & 1 & 1 & 14 & 20 \\
\hline p,p'-DDE & USGS(1) & 8 & 11 & 11 & 3 & 11 \\
\hline Parathion & USGS(1) & 11 & 11 & 11 & 4 & 23 \\
\hline \multirow[t]{2}{*}{ Parathion-methyl } & PADEPL & 13 & 3 & 3 & 5 & 23 \\
\hline & USGS(1) & 10 & 11 & 11 & 4 & 20 \\
\hline Pebulate & USGS(1) & 10 & 11 & 11 & 2 & 8 \\
\hline \multirow[t]{2}{*}{ Pendimethalin } & PADEPL & 22 & 4 & 4 & 9 & 8 \\
\hline & USGS(1) & 19 & 11 & 11 & 5 & 16 \\
\hline Perylene-d12 (surrogate) & PADEPL & 4 & 4 & 4 & 2 & 16 \\
\hline Phorate & USGS(1) & 20 & 11 & 11 & 3 & 33 \\
\hline Phosphamidon & PADEPL & 17 & 2 & 2 & 8 & 17 \\
\hline Phosmet & PADEPL & - & 0 & - & - & 47 \\
\hline Picloram & USGS(1) & - & 0 & - & - & 15 \\
\hline Prometon & USGS(1) & 8 & 11 & 11 & 2 & 16 \\
\hline Propachlor & USGS(1) & 14 & 11 & 11 & 2 & 15 \\
\hline
\end{tabular}


Table 2-2. Estimates of bias and variability in reported concentrations of nitrate, nitrite, total coliform and Escherichia coli (E. coli) bacteria, and pesticides using results from field-submitted and laboratory quality-control samples.-Continued

\begin{tabular}{|c|c|c|c|c|c|c|c|}
\hline \multirow{6}{*}{ Compound } & \multirow{6}{*}{$\begin{array}{l}\text { Lab } \\
\text { used }\end{array}$} & \multicolumn{6}{|c|}{ Evaluation of bias } \\
\hline & & \multicolumn{6}{|c|}{ Data sets used } \\
\hline & & \multicolumn{5}{|c|}{ Field-submitted samples } & \multirow{3}{*}{$\begin{array}{c}\text { LRS samples } \\
\text { (Numbers of } \\
\text { spikes, } \\
\text { period of record, } \\
\text { and spike } \\
\text { concentrations } \\
\text { found in } \\
\text { footnote 2) } \\
\text { Bias, } \\
\begin{array}{c}\text { using recoveries } \\
\text { in percent }\end{array} \\
\end{array}$} \\
\hline & & & lank $s$ & & $\begin{array}{c}\text { SRWS } \\
\text { samples } \\
\text { triplic } \\
\text { (Spike } \\
\text { SRWS }\end{array}$ & $\begin{array}{l}\text { icate FSRW } \\
\text { and nitrite); } \\
W \text { samples } \\
\text { des) } \\
\text { rrations and } \\
\text { rs found in } \\
\text { e 1) }\end{array}$ & \\
\hline & & \multicolumn{3}{|c|}{$\begin{array}{l}\text { Bias, using concentration } \\
\text { (detections result in false } \\
\text { positives due to contamination) }\end{array}$} & \multicolumn{2}{|c|}{$\begin{array}{c}\text { Bias, } \\
\text { using recoveries, } \\
\text { in percent }\end{array}$} & \\
\hline & & $\mathbf{B}_{\mathrm{N}}$ & $\mathbf{B}_{\mathrm{ND}}$ & \begin{tabular}{|c|} 
Maximum \\
reported \\
concentration in \\
blanks
\end{tabular} & $\mathrm{S}_{\mathrm{N}}$ & $\begin{array}{l}\text { Median } \\
\text { recovery, } \\
\text { in percent }\end{array}$ & $\begin{array}{l}\text { Median recovery } \\
\text { in percent }\end{array}$ \\
\hline Propanil & USGS(1) & 10 & 0 & - & 33 & 108 & 106 \\
\hline Propargite & USGS(1) & 10 & 0 & - & 33 & 69 & 78 \\
\hline Propham & USGS(1) & 1 & 0 & - & 0 & - & 88 \\
\hline Propiconazole & USGS(1) & 1 & 0 & - & 0 & - & 94 \\
\hline Propoxur & USGS(1) & 1 & 0 & - & 3 & 79 & 85 \\
\hline Propyzamide (pronamide in 2003) & USGS(1) & 10 & 0 & - & 33 & 106 & 98 \\
\hline Pyrene-d10 (surrogate) & PADEPL & 3 & - & - & 12 & 104 & 103 \\
\hline Siduron & USGS(1) & 1 & 0 & - & 0 & - & 93 \\
\hline \multirow[t]{2}{*}{ Simazine } & PADEPL & 3 & 0 & - & 12 & 100 & 97 \\
\hline & USGS(1) & 10 & 0 & - & 33 & 104 & 91 \\
\hline Sulfometuron-methyl & USGS(1) & 1 & 0 & - & 0 & - & 130 \\
\hline Tebuthiuron & USGS(1) & 11 & 0 & - & 33 & 102 & $118(97)$ \\
\hline \multirow[t]{2}{*}{ Terbacil } & PADEPL & 2 & 0 & - & 9 & 105 & 101 \\
\hline & USGS(1) & 11 & 0 & - & 33 & 63 & $88(90)$ \\
\hline Terbufos & USGS(1) & 10 & 0 & - & 33 & 79 & 75 \\
\hline Thiobencarb & USGS(1) & 10 & 0 & - & 33 & 118 & 103 \\
\hline Triallate & USGS(1) & 10 & 0 & - & 33 & 101 & 95 \\
\hline Triphenylphosphate (surrogate) & PADEPL & 3 & - & - & 12 & 125 & 121 \\
\hline Triclopyr & USGS(1) & 1 & 0 & - & 0 & - & 94 \\
\hline \multirow[t]{2}{*}{ Trifluralin } & PADEPL & 2 & 0 & - & 6 & 86 & 79 \\
\hline & USGS(1) & 10 & 0 & - & 33 & 75 & 76 \\
\hline
\end{tabular}

${ }^{1}$ Recoveries of nitrate and nitrite used from SRWS N78 (2003), SRWS N82 (2004), SRWS N86 (2005), SRWS N90 (2006), and SRWS N91 (2007) and also recoveries of nitrate and nitrite in FSRW samples; spike concentrations of nitrate/nitrite in triplicate FSRW samples: $5.61 \mathrm{mg} / \mathrm{L} / 0.95 \mathrm{mg} / \mathrm{L}$ (2003); $7.50 \mathrm{mg} / \mathrm{L} / 0.75 \mathrm{mg} / \mathrm{L}$ (2004); $8.68 \mathrm{mg} / \mathrm{L} / 1.83 \mathrm{mg} / \mathrm{L}$ (2005); $8.41 \mathrm{mg} / \mathrm{L} / 1.01 \mathrm{mg} / \mathrm{L}$ (2006); and $3.81 \mathrm{mg} / \mathrm{L} / 1.67 \mathrm{mg} / \mathrm{L}$ (2007). Pesticide FSRW samples analyzed at the USGS NWQL were spiked to a concentration of $0.4 \mu \mathrm{g} / \mathrm{L}$ for samples using the GCMS method (33 samples). Three pesticide FSRW samples, spiked at $3.2 \mu \mathrm{g} / \mathrm{L}$ for carbaryl and carbofuran, were also analyzed at the NWQL using the HPLCMS method; bias and variability data for these three samples were not included in the statistics presented in this table. Pesticide FSRW samples analyzed at the PADEPL were spiked to a concentration of $0.4 \mu \mathrm{g} / \mathrm{L}$ for compounds analyzed using USEPA 525.2 method and $3.2 \mu \mathrm{g} / \mathrm{L}$ for carbaryl, methomyl, and oxamyl compounds analyzed using USEPA 531.1.

${ }^{2}$ USGS NWQL LRS median recoveries and associated F-pseudosigmas data are based on data compiled for 2002-06 pesticide compounds analyzed by GCMS methodology (table 2-4); data statistics are based on between 968-1,417 spike results. LRS are spiked to a concentration of $0.1 \mu \mathrm{g} / \mathrm{L}$ for the GCMS method. USGS(1) LRS median recoveries and associated F-pseudosigmas for pesticide compounds analyzed by HPLCMS methodology (table 2-5) are based on data compiled from 2/7/02-2/7/03, approximately 235 spike results, at a concentration of $0.25 \mu \mathrm{g} / \mathrm{L}$ (Sonja Abney, U.S. Geological Survey, written commun., December, 2008). When common pesticide compounds were analyzed using the GCMS and LCMS methodologies, parentheses are used to denote the recoveries for the HPLCMS method. PADEP LRS median recoveries for compounds analyzed by USEPA method 525.2 were calculated from recovery information for batch-set lab-reagent-spikes; the number of spike recoveries used to calculate medians and F-pseudosigmas ranged from 5 to 17, depending on the compound, and spiked to concentrations of $0.5 \mu \mathrm{g} / \mathrm{L}$ or $1.0 \mu \mathrm{g} / \mathrm{L}$. Laboratory reagent-spike samples are not analyzed for method USEPA 531.1 at the PADEPL as internal QC samples. Carbaryl, oxymyl, and methomyl batch matrix spike recoveries are used as estimates of method performance, assuming LRS data would give recoveries closer to 100 percent in the absence of matrix effects; calculations of lab median recoveries and F-pseudosigmas were done using all matrix spike-recovery data for batches which included project samples for PADEPL results for carbaryl, oxymyl, and methomyl, spiked at a concentration of $20 \mu \mathrm{g} / \mathrm{L}$.

${ }^{3}$ Surrogate recoveries were used for RSD calculations instead of concentrations.

${ }^{4}$ Compound not qualified due to possible error in field-spiked reagent water sample preparation — recoveries, therefore, are shown in parentheses. 
Table 2-2. Estimates of bias and variability in reported concentrations of nitrate, nitrite, total coliform and Escherichia coli (E. coli) bacteria, and pesticides using results from field-submitted and laboratory quality-control samples. - Continued

\begin{tabular}{|c|c|c|c|c|c|c|}
\hline \multirow{6}{*}{ Compound } & \multirow{6}{*}{$\begin{array}{l}\text { Lab } \\
\text { used }\end{array}$} & \multicolumn{5}{|c|}{ Evaluation of variability } \\
\hline & & \multicolumn{5}{|c|}{ Data sets used } \\
\hline & & \multicolumn{4}{|c|}{ Field-submitted samples } & \multirow[b]{2}{*}{$\begin{array}{l}\text { LRS samples } \\
\text { (Numbers of } \\
\text { spikes, } \\
\text { period of record, } \\
\text { and spike } \\
\text { concentrations } \\
\text { found in } \\
\text { footnote 2) }\end{array}$} \\
\hline & & \begin{tabular}{|} 
SRWS and triplicate \\
FSRW samples \\
(nitrate and nitrite); \\
triplicate FSRW samples \\
(pesticides)
\end{tabular} & tripl & $\begin{array}{l}\text { icate env } \\
\text { triplicate } \\
\text { trate and } \\
\text { plicate e } \\
\text { I coliforn } \\
\text { SRW sam }\end{array}$ & $\begin{array}{l}\text { ps. and } \\
\text { RW } \\
\text { rite); } \\
\text { reps } \\
\text { cteria); } \\
\text { s (pesticides) }\end{array}$ & \\
\hline & & $\begin{array}{l}\text { Variabiliy, using } \\
\text { F-pseudosigma of } \\
\text { recoveries, } \\
\text { in percent. } \\
\end{array}$ & \multicolumn{3}{|c|}{$\begin{array}{c}\text { Variability, using median relative } \\
\text { standard deviation (RSD) of concentrations } \\
\text { in triplicate } \text { sets }^{3}\end{array}$} & \multirow{2}{*}{$\begin{array}{c}\text { Variabiliy, } \\
\text { using } \\
\text { F-pseudosigma of } \\
\text { recoveries, } \\
\text { in percent. } \\
\begin{array}{c}\text { F-pseudosigma, } \\
\text { in percent }\end{array}\end{array}$} \\
\hline & & $\begin{array}{l}\text { F-pseudo-sigma, } \\
\text { in percent }\end{array}$ & $\mathbf{R}_{\mathrm{N}}$ & $\mathbf{R}_{\text {SETdeCt }}$ & $\begin{array}{l}\text { Median RSD, in } \\
\text { percent }\end{array}$ & \\
\hline Propanil & USGS(1) & 17 & 11 & 11 & 3 & 17 \\
\hline Propargite & USGS(1) & 10 & 11 & 11 & 6 & 20 \\
\hline Propham & USGS(1) & - & 0 & - & - & 10 \\
\hline Propiconazole & USGS(1) & - & 0 & - & - & 12 \\
\hline Propoxur & USGS(1) & 7 & 1 & 1 & 12 & 11 \\
\hline Propyzamide (pronamide in 2003) & USGS(1) & 10 & 11 & 11 & 2 & 11 \\
\hline Pyrene-d10 (surrogate) & PADEPL & 11 & 4 & 4 & 6 & 10 \\
\hline Siduron & USGS(1) & - & 0 & - & - & 22 \\
\hline \multirow[t]{2}{*}{ Simazine } & PADEPL & 11 & 4 & 4 & 9 & 24 \\
\hline & USGS(1) & 11 & 11 & 11 & 2 & 27 \\
\hline Sulfometuron-methyl & USGS(1) & - & 0 & - & - & 21 \\
\hline Tebuthiuron & USGS(1) & 17 & 11 & 11 & 9 & $26(13)$ \\
\hline \multirow[t]{2}{*}{ Terbacil } & PADEPL & 9 & 3 & 3 & 8 & 26 \\
\hline & USGS(1) & 20 & 11 & 11 & 6 & $26(42)$ \\
\hline Terbufos & USGS(1) & 10 & 11 & 11 & 2 & 21 \\
\hline Thiobencarb & USGS(1) & 16 & 11 & 11 & 2 & 13 \\
\hline Triallate & USGS(1) & 16 & 11 & 11 & 2 & 12 \\
\hline Triphenylphosphate (surrogate) & PADEPL & 12 & 4 & 4 & 1 & 18 \\
\hline Triclopyr & USGS(1) & - & 0 & - & - & 9 \\
\hline \multirow[t]{2}{*}{ Trifluralin } & PADEPL & 16 & 2 & 2 & 12 & 28 \\
\hline & USGS(1) & 9 & 11 & 11 & 3 & 13 \\
\hline
\end{tabular}




\section{Appendix 3. List of Electronic Databases Used in This Report}

\section{Description of contents of database}

Local number, station number, dates and times of sample collection, depth of well, depth to water level, and field parameter and waterquality results for wells sampled for the Blue Ridge crystalline and Triassic Lowland siliciclastic hydrogeologic setting baselineassessment area, 2003

Local number, station number, dates and times of sample collection, depth of well, depth to water level, and field parameter and waterquality results for wells sampled for the Eastern Lake surficial hydrogeologic setting baseline-assessment area, 2004

Local number, station number, dates and times of sample collection, depth of well, depth to water level, and field parameter and water-quality results for wells sampled for the Devonian-Silurian carbonate hydrogeologic setting baseline-assessment area, 2005

Local number, station number, dates and times of sample collection, depth of well, depth to water level, and field parameter and waterquality results for wells sampled for the Great Valley siliciclastic hydrogeologic setting baseline-assessment area, 2006

Local number, station number, dates and times of sample collection, depth of well, depth to water level, and field parameter and waterquality results for wells sampled for the Northeastern Glaciated surficial hydrogeologic setting baseline-assessment area, 2007

Local number, station number, dates and times of sample collection, depth of well, depth to water level, and field parameter and waterquality results for wells in baseline-assessment areas (four settings vulnerable to pesticide contamination), 2003 and 2004

Local number, station number, dates and times of sample collection, depth of well, depth to water level, and field parameter and waterquality results for hot-spot well BA 437, 2003 to 2007

Local number, station number, dates and times of sample collection, depth of well, depth to water level, and field parameter and waterquality results for hot-spot well LN 1842, 2003 to 2007

Local number, station number, dates and times of sample collection, depth of well, depth to water level, and field parameter and waterquality results for hot-spot well BE 1370, 2003 to 2007

Local number, station number, dates and times of sample collection, depth of well, depth to water level, and field parameter and waterquality results for three hot-spot and neighboring wells, 2005 and 2006.
BASELINE_OCCURRENCE2003a.Monitoring.xls

BASELINE_OCCURRENCE2003bMonitoring.xls

(because of MicroSoft Excel space limitations, two files were needed to provide results for all compounds analyzed)

BASELINE_OCCURRENCE2004Monitoring.xls

BASELINE_OCCURRENCE2005Monitoring.xls

BASELINE_OCCURRENCE2006Monitoring.xls

BASELINE_OCCURRENCE2007Monitoring.xls

CHANGEMonitoring_VulnerableSettings.xls

HOT-SPOTWellBA437SeasonalMonitoring.xls

HOT-SPOTWellLN1842SeasonalMonitoring.xls

HOT-SPOTWellBE1370SeasonalMonitoring.xls

HOT-SPOTWellsandNeighborWells.xls 


\section{Appendix 4. Regulatory Information for Compounds Measured in This Study}

[Concentrations are in micrograms per liter unless otherwise noted. USEPA, U.S.Environmental Protection Agency; MCL, maximum contaminant level; LHA, lifetime health advisory; PDA, Pennsylvania Department of Agriculture; -, no standard; http://www.epa.gov/waterscience/criteria/drinking/dwstandards.html, accessed June 23, 2008; bolding indicates standard used to calculate action level]

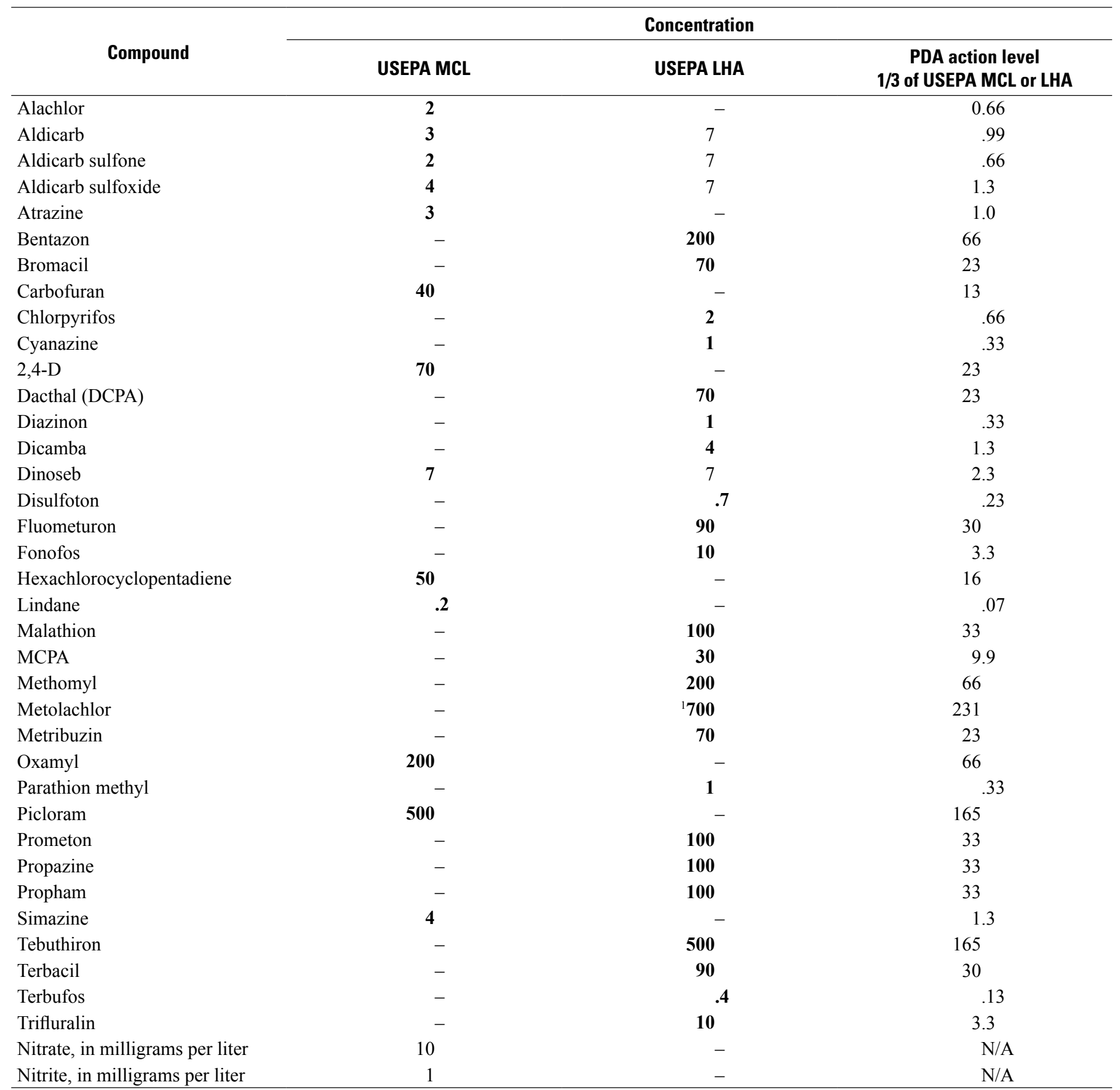

${ }^{1}$ The newly proposed "ambient water-quality human-health criteria" for metolachlor is $69 \mu \mathrm{g} / \mathrm{L}$ (Pennsylvania Department of Environmental Protection, 2008, Triennial review of water quality standards: Pennsylvania Bulletin, v. 38, no. 2 (January 12, 2008), p. 241). 

